\title{
BIRDS OF THE ST. CROIX RIVER VALLEY: MINNESOTA AND WISCONSIN
}

\author{
by \\ Craig A. Faanes
}

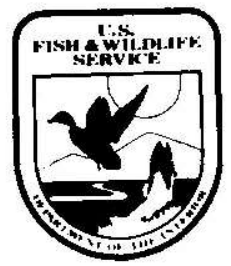

\section{UNITED STATES DEPARTMENT OF THE INTERIOR} FISH AND WILDLIFE SERVICE

North American Fauna, Number 73

Washington, D.C. $\bullet 1981$ 


\section{Contents}

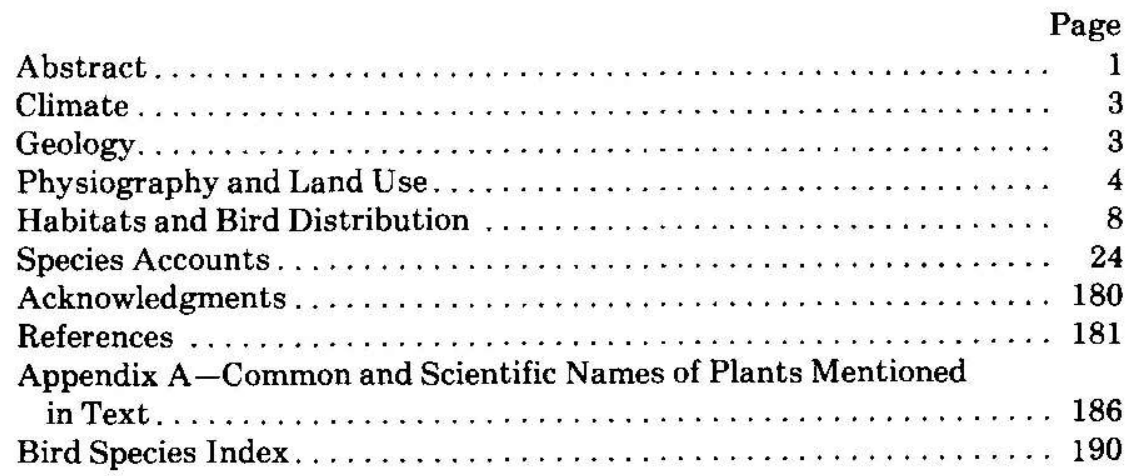

Dedicated to

Samuel D. Robbins, Jr.

Ornithologist and Friend 


\title{
Birds of the St. Croix River Valley: Minnesota and Wisconsin
}

\author{
by \\ Craig A. Faanes \\ U.S. Fish and Wildlife Service \\ Northern Prairie Wildlife Research Center \\ Jamestown, North Dakota 58401
}

\begin{abstract}
The St. Croix River Valley encompasses nearly $11,550 \mathrm{~km}^{2}$ in east-central Minnesota and northwestern Wisconsin. A wide range of habitats are available for birds including upland oak, lowland deciduous, maple-basswood, lowland and upland coniferous forests, natural basin wetlands, and grasslands. Situated in the north-central region of the United States, the valley is a biological "crossroads" for many species. Because of the mixed affinities of plant communities, the valley includes the northern and southern range limits for a number of species. Also, because the valley lies near the forest-prairie transition zone, many typical western breeding species (e.g. pintail, western meadowlark, yellow-headed blackbird) breed in proximity to typical eastern species such as tufted titmouse, eastern meadowlark, and cardinal.

From 1966 to 1980 , I conducted extensive surveys of avian distribution and abundance in the St. Croix River Valley. I have supplemented the results of these surveys with published and unpublished observations contributed by many ornithologists. These additional data include compilations from Christmas Bird Counts sponsored by the National Audubon Society and from the Breeding Bird Survey coordinated by the U.S. Fish and Wildlife Service. Three hundred fourteen species have been recorded in the study area; data are presented on the migration period, nesting season distribution, winter distribution, relative abundance, and habitat use of each species.

Recognizing the uniqueness of the area, and its importance not only to wildlife but also to man, the U.S. Congress designated the St. Croix a National Scenic Riverway. This action provided a considerable degree of protection to lands along and directly adjacent to the river. Unfortunately, no similar legal measure exists to protect lands away from the river. With the exception of the northern quarter of the St. Croix River Valley, agricultural interests have made significant inroads into the habitat base. The continuing expansion of the nearby Minneapolis-St. Paul metropolitan region has degraded or destroyed many woodlots, upland fields, and wetlands. In numerous instances, degradation of natural habitats has influenced the abundance and distribution of bird species. Because of these changes, both the Federal government and State Departments of Natural Resources have listed several species in various categories based on their current status. In the St. Croix River Valley, seven species are endangered, eight are threatened, and 29 are watch or priority status in either or both states. Data presented in this report are of value to land managers, land use specialists, and ornithologists, in assessing current and projected habitat alterations on the avifauna of this valley.
\end{abstract}


The St. Croix River bisects a large region of western Wisconsin and east central Minnesota that exhibits a wide range of habitat types. This region supports not only birds, but many mammals, fishes, reptiles and amphibians, and several thousand species of vascular and nonvascular plants. The river itself is relatively clean through most of its course, and its natural flow is interrupted by only two small dams.

Because the river lies within a 1-day drive of nearly 10 million people (Waters 1977), use of the area for recreational purposes is extremely heavy. Recreational pursuits include sunbathing, boating, and wild river kayaking in the summer, and ice fishing and cross-country skiing in the winter. The large number of unique and highly fragile habitats that exist there may never be compatible with the uses and abuses of the land that go with expanding human populations.

Through the efforts of a number of citizens concerned with the quality of their environment and the foresightedness of several local, State, and Federal legislators, a portion of the upper St. Croix River Valley (hereafter termed "the Valley") was established as a National Wild and Scenic River. Through establishment of the National Wild and Scenic Rivers Act (P.L. 90:542), the ground rules were established to preserve free-flowing streams that have "outstandingly remarkable scenic, recreational, geologic, fish and wildlife, historic, cultural, and other similar values." Any person who has spent time along a stretch of the St. Croix would have to agree that this river meets or exceeds all the criteria that the Act established.

The history of this magnificent valley is cloaked with the adventures of lumber barons, trappers and hunters, commercial fishermen, and many others. During the days of the early voyageurs, the river served as a vital link between the Great Lakes and the growing Minneapolis-St. Paul area. Excellent descriptions of the colorful history of the Valley are provided by Link (1977) and Waters (1977).

Although the Scenic River Act provides considerable protection for the lands and resources directly adjacent to the river, there is no comparable legal measure to protect lands not bordering the river. Several man-influenced impacts are escalating in the Valley and provide a continual threat to remaining resources. Two influences providing the greatest threat to the natural resources of the Valley are urban expansion and agricultural production. First, the continual, almost unabated spread of urban development has already had a profound impact on existing habitats. Second, agriculture has had a growing impact on bird life in the Valley. Lands producing row crops, small grains, and hay in St. Croix County in 1967 totaled 75,910 ha. This acreage increased $17.4 \%$ to 88,057 ha by 1977 (U.S. Department of Agriculture, personal communication). The total hectarage of lands in agricultural production (row crops and hay) made up 16 and $18.8 \%$ of the Valley in 1967 and 1977, respectively. These examples suggest the magnitude of the impact that agriculture has had upon wildlife resources in the past two decades.

It can be argued that the agricultural hectarages cited above represent changes in cropping practices rather than actual increases in the hectarage of wildlife habitat converted to agricultural production. However, increased technology and the growth of agribusiness have resulted in a shift to fencerow to fencerow farming with serious impacts on many upland habitats. 
Wetland habitats have also been significantly reduced. Peterson (1978) showed that over $27 \%$ of the seasonal wetlands (Type III of Shaw and Fredine 1956) in St. Croix County were drained between 1958 and 1977.

The objective of this report is to provide, in condensed form, an account of the 314 bird species that have been recorded in the Valley.

\section{Climate}

The Valley has a temperate, continental climate that is characterized by extreme seasonal variability. Mean monthly air temperatures are -12 to $-9^{\circ} \mathrm{C}$ in January and 20 to $22^{\circ} \mathrm{C}$ in July. The average growing season ranges from 100 days in the north (Burnett and Pine counties) to over 120 days in the south (St. Croix and Washington counties). The ground is frozen usually from late November through mid-April and frost depths range from 66 to $86 \mathrm{~cm}$.

Mean annual precipitation is $74.4 \mathrm{~cm}$ (Young and Hindall 1973). The range in yearly precipitation is about $71.1 \mathrm{~cm}$ at St. Croix Beach, Washington County, to nearly $78.7 \mathrm{~cm}$ at Grantsburg, Burnett County (Lindholm et al. 1974). Periods of prolonged drought are highly infrequent. February is usually the driest month $(<2.5 \mathrm{~cm})$ and June the wettest $(12.2 \mathrm{~cm})$. Annual evapotranspiration from the St. Croix watershed is $59.4 \mathrm{~cm}$ (Lindholm et al. 1974). During July and August, when temperatures are highest and plant moisture demands are greatest, evapotranspiration often exceeds precipitation.

\section{Geology}

Interpretations of the interrelation of birds and other wildlife with their environment require an understanding of the geology and soils of an area. The St. Croix River Valley is an area rich in geologic history. Sediments and rock formations throughout the Valley range in geologic age from the 1-billion-year-old Precambrian lava flows at Interstate Park to very recent sediment deposition at the mouth of the Kinnickinnic River.

Bedrock in the upper portion of the Valley consists primarily of Precambrian igneous lava flows, shales, sandstones, and igneous and metamorphic crystalline formations. Bedrock of the lower portions of the Valley consists of marine sandstones, shales, and limestones that were deposited during the Cambrian and Ordovician periods. Outcroppings southward through the Valley indicate that bedrock formations are progressively younger.

Glacial deposits consist mainly of undifferentiated till that was deposited as the last glacier melted about 10,000 years ago. This glacial action was very important in forming the current features of the landscape. Especially important and characteristic among these glacial deposits are the extensive sandy soils associated with the bed of Glacial Lake Grantsburg in Burnett and Pine counties, and the numerous prairie pothole-type wetlands that occur in Polk, St. Croix, and Washington counties.

One important result of past glacial activity in the St. Croix River Valley is the highly productive soils that formed on the glacial outwash. Through 
the combined action of climate, vegetation, and proper acidity of these glacial deposits, soils developed that are very important for agricultural production. Productivity of all soils in the Valley is, of course, not equal. Soil conditions range from the sandy, acidic beach-derived soils associated with Glacial Lake Grantsburg, to the deep, rich loams and silt loam prairie soils of the lower Valley. Productivity of these soils for wildlife appears to correlate nicely. For example, the acidic soils of Glacial Lake Grantsburg are usually associated with relatively sterile Jack Pine Barren forest which supports limited wildlife populations. On the other extreme, the deep, rich prairie soils of the southern regions produce exceptional agricultural crops and also support large and highly diverse wildlife populations.

\section{Physiography and Land Use}

The diverse physiographic and topographic features of the Valley result from at least four different glacial epochs that extended from 1 million to 10,000 years ago. The St. Croix River itself is an important component of past and present physiographic changes. The gradient of the river averages $102 \mathrm{~cm}$ per $\mathrm{km}$ across its entire course, ranging from nearly zero on Lake St. Croix to $4.3 \mathrm{~m}$ per $\mathrm{km}$ at the Kettle River Rapids, Pine County (Young and Hindall 1973). Altitude of the land surface ranges from about $207 \mathrm{~m}$ above sea level at Prescott to about $518 \mathrm{~m}$ near Cable at the upper end of the Namekagon River. The interior of the Valley has a general slope ranging from $427 \mathrm{~m}$ in the north to about $305 \mathrm{~m}$ in the south.

During the last glacial period the St. Croix served as a major drainage for glacial melt waters. Martin (1932) reported that the post-glacial course of the river contained the Apple River Valley in western Wisconsin. In preglacial times, the major course of the river was farther west in Minnesota. In addition to carrying melt waters from the glacier, the St. Croix carried overflow waters from large glacial lakes that occurred in the Lake Superior basin. One outlet was the valley at Solon Springs which is now occupied by St. Croix Lake, the headwaters of the river (Young and Hindall 1973).

Topography of the Valley includes flat-topped, steep-sided sedimentary hills adjacent to the river, and narrow stream valleys in the extreme lower reaches. The remainder of the Valley is composed primarily of broad, flat glacial outwash plains and kettle and knob topography associated with terminal and end moraines.

Lakes and marshes are abundant in the northern half of the Valley where surface drainage systems are poorly developed. One unique drainage system in southern Pine County is separated from all other watersheds in the region by a zone of elevated igneous bedrock. Marshes and streams in this region are characterized by low alkalinity and a deep brownish stained color (Waters 1977). In the southern reaches of the Valley, alkalinity and vegetation of lakes and marshes become progressively greater owing primarily to limestone and sandstone bedrock.

The entire St. Croix watershed encompasses about $11,550 \mathrm{~km}^{2}(1.7 \mathrm{mil}-$ lion ha). The river drains about $7,233 \mathrm{~km}^{2}$ in Wisconsin and $4,317 \mathrm{~km}^{2}$ in Minnesota (Lindholm et al. 1974). Included in the watershed are all or part of 


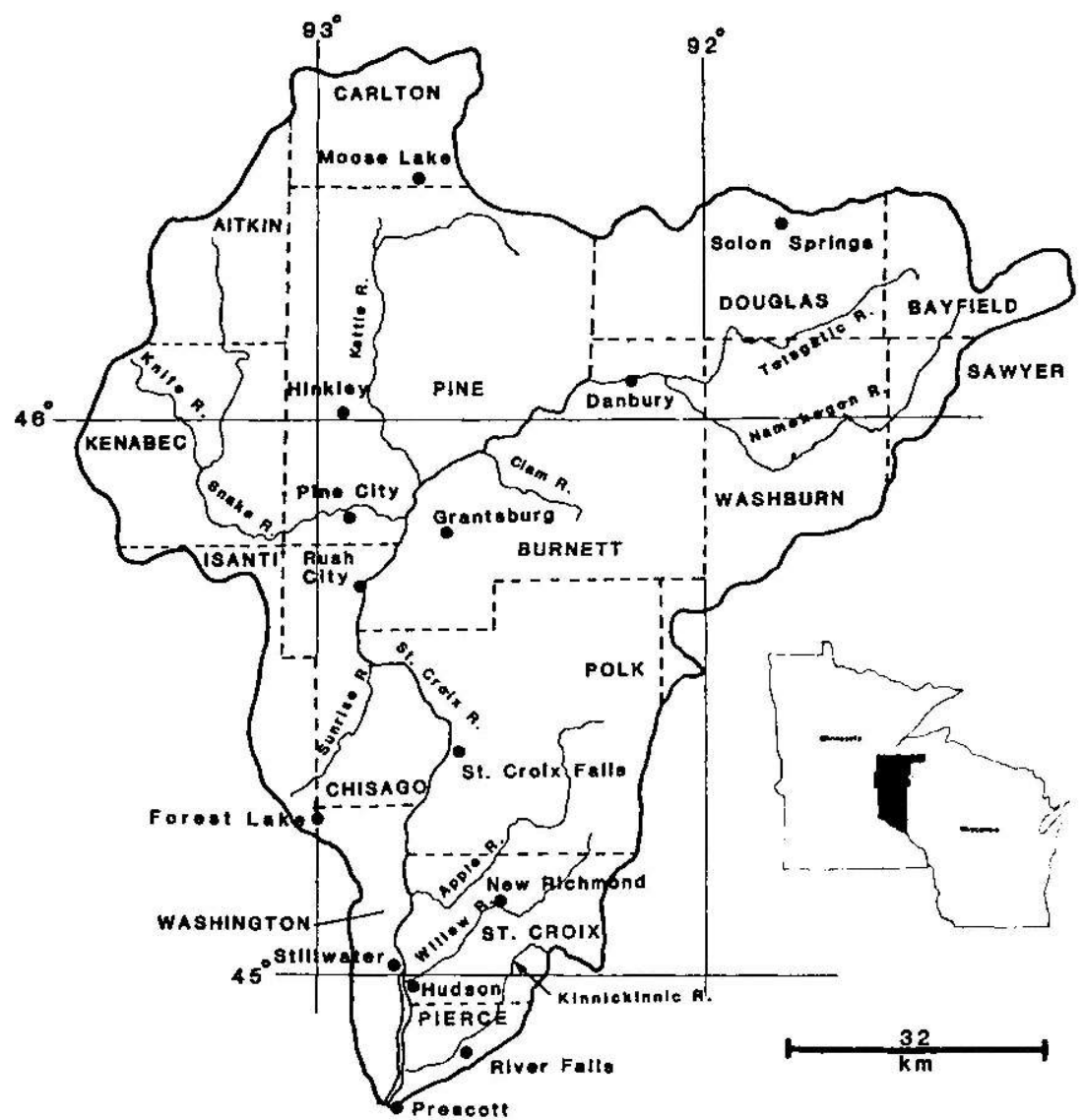

Fig. 1. The St. Croix River watershed, including Minnesota and Wisconsin, encompasses nearly $11.550 \mathrm{~km}^{2}$.

18 counties, 9 in each State (Fig. 1). There are eight major streams or watersheds that are tributary to the St. Croix, including the Snake and Kettle rivers, and Pine County streams in Minnesota (Waters 1977), and the Namekagon, Clam, Apple, Willow, and Kinnickinnic rivers in Wisconsin.

Related to the tremendous amount of diversity and variability in the topography and geology of the St. Croix River Valley, various geographers and plant ecologists have developed systems for classifying landforms and major vegetative communities (Fig. 2). These systems have provided divisions that are important in understanding the interrelation of bird distribution with vegetation and geomorphic features. Two separate systems have been developed, one for each State. Both systems have considerable merit considering the foundation upon which they were based. Unfortunately, these separate systems make interpretation of bird distribution awkward when considering the two States. Following is a brief overview of these 


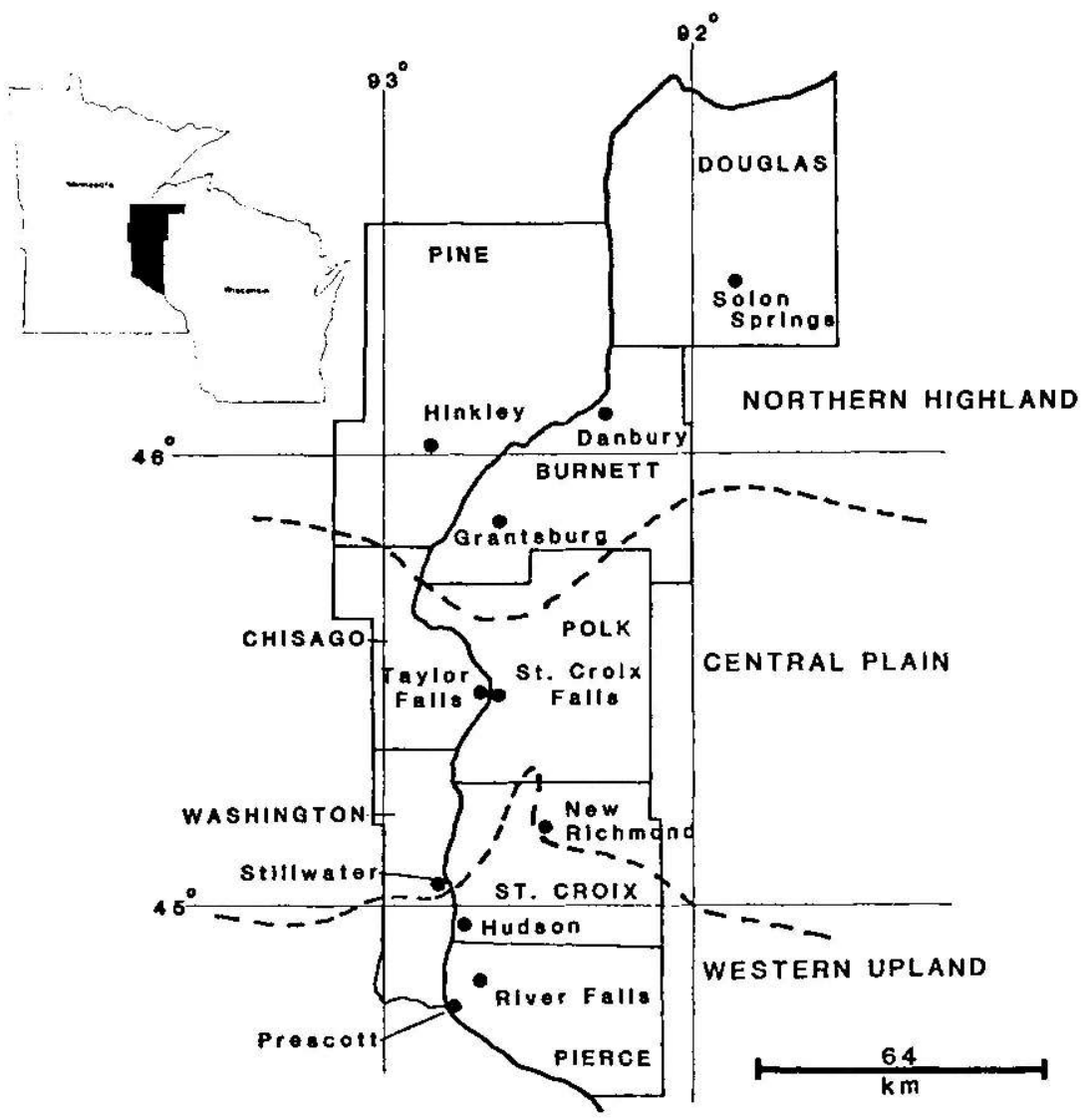

Fig. 2. Major physiographic regions of the St. Croix River Valley.

major divisions by State and the reasons for the combining of systems that I had to consider for interpretation.

The most usable division system for Minnesota was developed by Kratz and Jensen (1977). They developed a system based on both major vegetational and geomorphic provinces and included 17 distinct Ecological-Geomorphic divisions. Four of these divisions are included in the Minnesota counties. A brief description of each follows.

Southern Oak Barrens Section. - This section includes a large region of southeastern Minnesota generally referred to as the Driftless Area, which was not covered by ice during glacial periods. In the Valley, about $80 \%$ of Washington County is included in this section. Topography is characterized by highly dissected limestone and sandstone hills adjacent to the St. Croix River. Away from the river, large expanses of glacial outwash and kettle and knob topography predominate. Vegetation consists of a transition between 
prairie and deciduous forests. Originally, oak barrens and savannah occurred throughout this area.

Mississippi River Sand Plains Section.-This section includes a small portion of northwestern Washington and southwestern Chisago counties where topography is characteristic of glacial outwash plains-including broad, flat areas with occasional wetland basins interspersed. Original vegetation of the sand outwash soils was primarily oak forest with scattered prairie openings and wet prairie in depressions.

Grantsburg Section. - This section includes most of Chisago County and a small part of southern Pine County. Topography is characterized by flat to gently rolling glacial sediments that are frequently dissected by streams. The Grantsburg section includes the bed of Glacial Lake Grantsburg, which extended eastward into Burnett County, Wisconsin. Vegetation originally included Jack Pine Barrens and scattered oak openings. Currently, much of the land is in agricultural production.

Mille Lacs Section. - This section includes most of southern and all of northern Pine County. Topography is characterized by glacial scoured bedrock and glacial till that provide a kettle and knob topography. Forest-bordered lakes are numerous throughout this section. Vegetation is characterized by mixed northern hardwood and coniferous stands with conifer bogs interspersed throughout.

The classification system used in Wisconsin (Martin 1932) is based primarily on physiographic features and bedrock geology, regardless of vegetation. However, the influence of physiography on vegetation is well demonstrated in Wisconsin because the regions that occur in the Valley each support entirely different vegetative communities. Martin considered five distinct physiographic provinces in Wisconsin and the Valley is included in three.

Western Upland. - This region in the Valley is the northern extension of the Driftless Area, a part of Wisconsin, Minnesota, and Illinois that was not covered by glacial ice. Included in the Western Upland are the highly dissected stream valleys adjacent to the St. Croix River and the broad and gently rolling glacial outwash plain of central St. Croix County. Original vegetation included Southern Oak Forest in the dissected area and Tall Grass Prairie associated with the outwash plain. At present, much of the Western Upland is in agricultural production. Portions of central St. Croix, southern Polk, and central Washington counties are dotted with numerous natural basin wetlands.

Central Plain.-This region includes northern St. Croix, southern Burnett, and most of Polk counties. Topography of the Central Plain is also characterized by broad glacial outwash plains lying over Cambrian sandstone in the southern regions. Extensive areas of kettle and knob topography associated with end moraines occur in the north. Numerous lakes and bogs are associated with this topography. Vegetation consists of a mixture of southern oak forest, prairie and northern mixed hardwood, and coniferous forest.

Northern Highland.-This region, which includes northern Burnett and southern Douglas counties, has topography characteristic of morainal 
deposits and includes numerous high, rounded hills composed of more resistant bedrock. Geology of this region is primarily highly resistant Precambrian igneous rock, quite unlike southern regions of the Valley. Original vegetation of the Northern Highland was composed almost exclusively of pine forest and coniferous bogs. Presently, the pine forest exists only as scattered remnants interspersed throughout extensive mixed second growth deciduous and coniferous forest. Large lakes and extensive bogs are characteristic of the Northern Highland.

This brief discussion of the major physiographic regions of the St. Croix River Valley points out both similarities and differences between the systems developed for each State. For the sake of convenience and clarity in describing bird occurrence and distribution, I have combined both systems. Thus, throughout this report reference to the Western Upland will include the Wisconsin areas outlined in Martin (1932) and the Southern Oak Barrens region of Minnesota described by Kratz and Jensen (1977). The Central Plain will include the Wisconsin areas outlined and those areas of Chisago and Washington counties included in the Mississippi River Sand Plains and the Grantsburg Section. Reference to the Northern Highland will include the Wisconsin areas and the Mille Lacs Section in Pine County. These agree closely with the physiographic regions used by the U.S. Fish and Wildlife Service's Breeding Bird Survey (BBS; Bystrak 1979).

\section{Habitats and Bird Distribution}

Within the Valley, a wide range of vegetational communities are available to birds: deciduous and coniferous forest, wetlands, agricultural lands, and urban-residential areas. Original vegetation of the Valley as described by Curtis (1959) and Marschner (1930) included Tall Grass Prairie and Oak Savannah in the Western Upland, Southern Hardwood Forest (primarily oak) and Tall Grass Prairie in the Central Plain, and mixed Coniferous-Deciduous Forest association in the Northern Highland (Fig. 3). Much of the bed of Glacial Lake Grantsburg was composed of relatively sterile jack pine and oak forest. (Scientific names of plants are given in Appendix A.)

Man's presence has had a profound impact on the composition, distribution, and extent of these major communities. The Tall Grass Prairie which may have lapped at the shoulders of early settlers is now field and pastures. The prairie is now confined to railroad rights-of-way and small odd corners that would not accommodate a plow. The majestic white pine forest that once blanketed most of the northern regions has been reduced to scattered remnants.

Habitat changes that adversely affect some bird species often encourage expansion of other species. The clearing of forests of northern white pine has allowed a second growth deciduous disclimax habitat type to develop. Land clearing for agriculture was very important to the advance of the greater prairie chicken (scientific names of birds are given in the species accounts) in this region. Early accounts make vivid reference to the large number of greater prairie chickens that occurred after moderate agricultural expansion. However, the rapacious clearing that accompanied intensified agricul- 


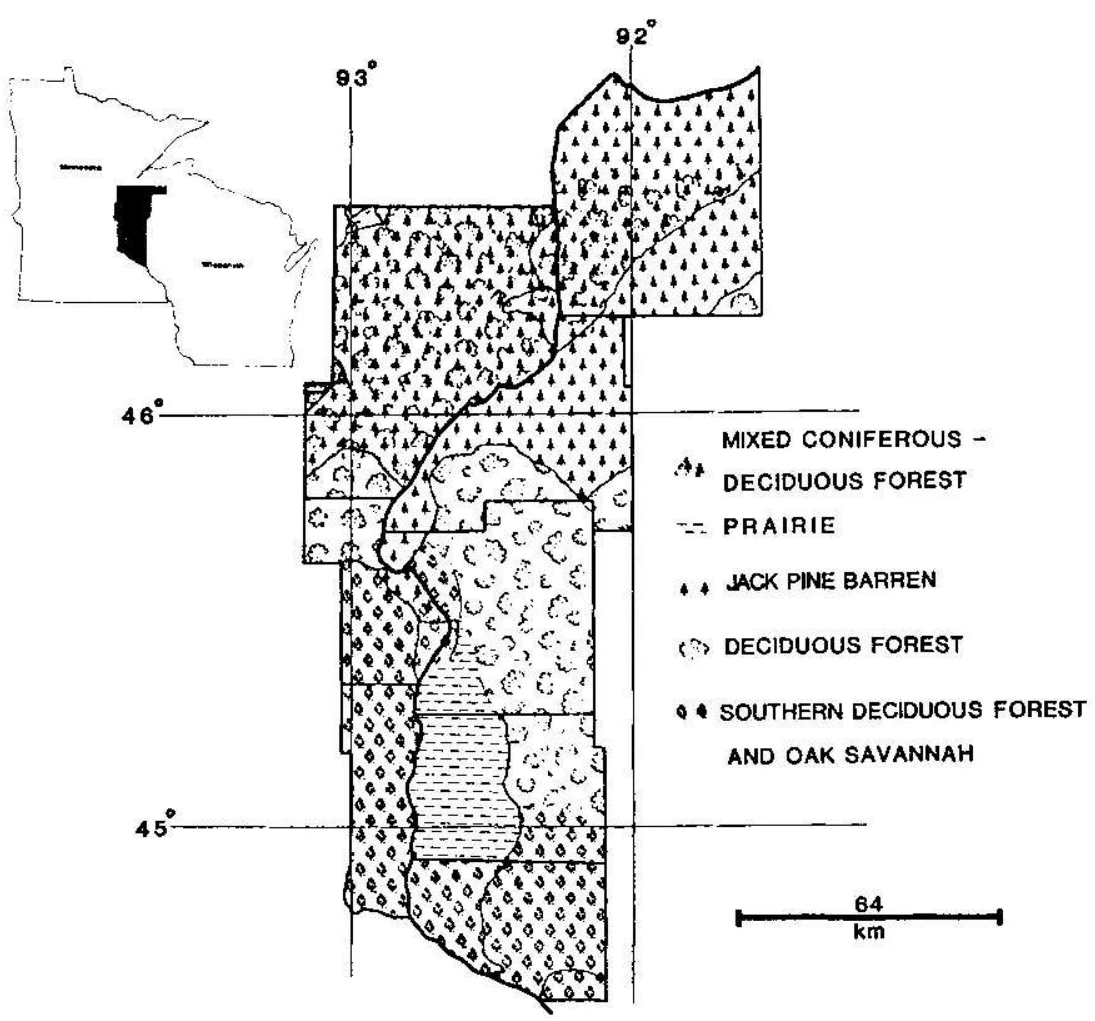

Fig. 3. Major vegetative communities of the St. Croix River Valley, adapted from Curtis (1959) and Marschner (1930).

tural production also caused the demise of the greater prairie chicken as a natural breeding bird.

An important environmental characteristic that affects bird occurrence and distribution is described by Curtis (1959) as the "Tension Zone." Based on a combination of environmental factors including soil type, annual precipitation, temperature, and geology, this zone of vegetational range extremes has a profound effect on the distribution of many bird species in the Valley. Essentially, this zone is the north-south limit area for many boreal forest and oak forest forbs, shrubs and trees. This contact zone was shown by Beimborn (1969) as important to the distribution of at least 14 bird species in Wisconsin. Robbins (1974b) demonstrated the influence of the Tension Zone on the breeding range limits of the alder and willow flycatchers.

Nineteen distinct habitat categories have been identified. Each is presented here in terms of size, distribution, floral characteristics, and characteristic breeding birds. Breeding bird species that apparently reach their greatest density in a specific habitat are marked with an asterisk. Habitat use by migrants will be considered individually with each species account. 


\section{Decíduous Forest Communities}

Northern Hardwood Forest

This floristic community extends throughout the Northern Highland and much of the Central Plain north of St. Croix Falls (Polk and Chisago counties). Characterized by a mixture of coniferous and deciduous tree types, the Northern Hardwood Forest occurs on a wide range of topographic sites and on many soil types. Mesic sites support white birch, sugar maple, hemlock, basswood, and red oak. Important coniferous species of this habitat are red pine, white pine, and to a limited extent jack pine. Depending on the extent of early successional stages this is generally a climax or near-climax community.

Prevalent within the shrub layer and among ground layer species are beaked hazel, bracken fern, wood anemone, wild sarsaparilla, big-leaf aster, blue bead lily, northern bedstraw, ground pine, Canada mayflower, bishop's cap, Solomon's seal, twisted stalk, starflower, downy yellow violet, rice grass, and Pennsylvania sedge.

Characteristic breeding birds include broad-winged Hawk*, ruffed grouse*, great horned owl, barred owl, black-billed cuckoo*, common flicker, yellow-bellied sapsucker*, hairy woodpecker*, downy woodpecker, great crested flycatcher, least flycatcher*, eastern wood pewee*, blue jay, northern raven, black-capped chickadee, white-breasted nuthatch, American robin, wood thrush, veery*, solitary vireo, red-eyed vireo*, black-and-white warbler, chestnut-sided warbler, ovenbird*, American redstart, northern oriole, scarlet tanager, rose-breasted grosbeak*, and white-throated sparrow.

\section{Lowland Deciduous Forest}

This rich deciduous community occurs primarily along the floodplains of larger streams and rivers adjacent to the St. Croix in the Western Upland and Central Plain. The abundant soil moisture from river flooding and high water table is a principal microclimatic feature of this community. Because of its southern plant affinity, Lowland Deciduous Forest attracts some typically southern breeding bird species that occur in no other habitat type. Major tree species characteristic of this community are silver maple, American elm, green ash, red oak, basswood, and cottonwood.

Prevalent species in the shrub layer are black willow, box-elder, and gray dogwood. Depending on the amount of disturbance by grazing cattle, tartarian honeysuckle and prickly ash approach dominance in the shrub layer. Important among ground layer species are jack-in-the-pulpit, toothwort, Virginia waterleaf, wood nettle, poison ivy, germander, hedge nettle, jewelweed, and skunk cabbage.

Characteristic breeding bird species of the Lowland Deciduous Forest include great blue heron*, wood duck*, red-shouldered hawk*, yellow-billed cuckoo, screech owl*, barred owl*, pileated woodpecker*, red-bellied woodpecker*, downy woodpecker, eastern wood pewee, tufted titmouse*, whitebreasted nuthatch*, blue-gray gnatcatcher*, yellow-throated vireo*, warbling vireo*, blue-winged warbler*, yellow warbler, cerulean warbler*, 
Louisiana waterthrush*, northern oriole*, scarlet tanager*, and rosebreasted grosbeak.

\section{Southern Deciduous Forest}

This habitat type includes a closed-canopy upland community that is generally restricted to the region south of the Tension Zone in the Western Upland and Central Plain. Southern Deciduous Forest occurs almost exclusively on dry, well-drained upland sites. Before settlement of this region, Southern Deciduous Forest existed as part of an oak forest intermixed with prairie giving the area aspects of a savannah. Currently, stands of Southern Deciduous Forest are primarily restricted to bluff tops and edges adjacent to the St. Croix River and in scattered farm woodlots, which are usually heavily grazed.

Important component trees in this community include red oak, white oak, Hill's oak, and bur oak. In more mesic sites, large-toothed aspen, sugar maple, basswood, and white ash become important. Shrubs indicative of this community include black cherry, common elder, gray dogwood, and hazelnut. Prevalent ground layer vegetation includes dogbane, wild sarsaparilla, rattlesnake fern, tick trefoil, Virginia strawberry, northern bedstraw, wild cranesbill, Jacob's ladder, sweet cicely, wild lettuce, false Solomon's seal, Solomon's seal, wild leek, blue cohosh, goosegrass, bloodroot, large-flowered trillium, and Pennsylvania sedge.

Very few breeding bird species are restricted to or reach their greatest density in the Southern Deciduous Forest in the Valley. Principal breeding species include Cooper's hawk, red-tailed hawk, ruffed grouse, great horned owl, whip-poor-will, common flicker, red-headed woodpecker*, hairy woodpecker, great crested flycatcher, eastern wood pewee, blue jay, common crow, black-capped chickadee, white-breasted nuthatch, house wren, brown thrasher*, American robin, yellow-throated vireo, ovenbird, American redstart, scarlet tanager, rose-breasted grosbeak, indigo bunting, rufous-sided towhee, vesper sparrow (in openings), and field sparrow (in openings).

\section{Deciduous Clear Cuts}

A major principle of wildlife management is the provision of a multitude of habitats in various successional stages. Suppression of wildfires and the tremendous reduction of logging that occurred after settlement of the Valley were responsible for allowing many upland sites to return to near climax conditions. Northern Hardwood Forest, dominated primarily by sugar maple and basswood, rapidly becomes prevalent in northern forests that are not managed. Although the mature hardwood forest is a primary habitat for several breeding birds, the lack of early successional stages creates a situation that is relatively unattractive to a number of other species.

Within the last 15 years, foresters and wildlife managers have taken steps to retard succession in several upland forest types. These management practices have been highly successful in providing a variety of successional stage forests and several age classes. Providing a variety of age classes has produced significant beneficial effects for many woodland breeding birds. The primary methods used to accomplish these practices are clear-cutting and selective cutting. 
In general, these practices have been accomplished on upland sites in the northern areas of the Central Plain and throughout the Northern Highland. Trembling aspen is the primary tree species associated with Deciduous Clear Cuts. Additional tree and shrub species that are important components of clear cuts include ironwood, hazelnut, sugar maple, and basswood. Important ground layer species include black raspberry, big-leaf aster, rice grass, bottle-brush grass, Pennsylvania sedge, northern bedstraw, bracken fern, and wood anemone. In wet-mesic sites bunchberry and large-flowered trillium are also important.

Deciduous Clear Cuts and associated edge habitat probably support the greatest diversity of breeding birds among the habitats in the Valley. Principal breeding species include ruffed grouse, ruby-throated hummingbird, eastern kingbird, alder flycatcher*, house wren, gray catbird*, brown thrasher, eastern bluebird, golden-winged warbler*, Nashville warbler, yellow warbler, chestnut-sided warbler*, mourning warbler*, common yellowthroat*, Canada warbler*, brown-headed cowbird, rose-breasted grosbeak, indigo bunting*, American goldfinch, white-throated sparrow*, and song sparrow.

\section{Coniferous Communities}

\section{Upland Coniferous Forest}

Before settlement of the Valley most of the Central Plain and Northern Highland was covered with Upland Coniferous Forest. Logging activities during the late 1800's and early 1900's altered much of this habitat; very few stands of pure Upland Coniferous Forest still exist. Probably the best representative stands occur in and near St. Croix State Park in Pine County and Lucius Woods State Park in Douglas County. In most instances this habitat occurs as small relicts intermixed with several Upland Deciduous Forest species. This habitat type is included because of its past dominance and existing relict stands.

Principal tree species associated with Upland Coniferous Forest are white pine and red pine. Important invaders include white birch, trembling aspen, red maple, sugar maple, black cherry, hazelnut, and ironwood. Prevalent ground layer vegetation includes wood anemone, wild sarsaparilla, big-leaf aster, Pennsylvania sedge, blue bead lily, bunchberry, wintergreen, ground pine, Canada mayflower, partridge berry, starflower, Indian pipe, and dwarf ginseng.

Important breeding bird species of the Upland Coniferous Forest include sharp-shinned hawk, pileated woodpecker, hairy woodpecker, eastern wood pewee, blue jay, common raven, black-capped chickadee, red-breasted nuthatch, hermit thrush, black-and-white warbler, yellow-rumped warbler, pine warbler*, Blackburnian warbler*, ovenbird, purple finch, pine siskin, darkeyed junco, and chipping sparrow.

\section{Lowland Coniferous Forest}

This habitat type occurs in numerous locations north of the Tension Zone. The frequency of the Lowland Coniferous Forest is high but is limited in 
extent, occurring primarily in three distinct topographic settings: river floodplains, ancient lake beds, and kettles associated with kettle and knob topography in morainal areas. Soils of this habitat are usually acidic and are composed of wet, decaying vegetation that in many instances gives the ground a spongy texture. This habitat type is similar in several respects to the original Boreal Forest. Because most of that habitat type has been destroyed or greatly altered, vegetative characteristics and breeding bird use of the two have been combined.

Principal tree species of the Lowland Coniferous Forest include white spruce, white cedar, balsam fir, yellow birch, black ash, and green ash. Tamarack, American elm, and occasionally red maple, are also important components of this habitat. Shrub layers are usually poorly developed in Lowland Coniferous Forest; green ash and mountain holly are usually the prevalent shrub species. Important species of the ground layer include blue bead lily, bunchberry, creeping snowberry, wintergreen, Labrador tea, Canada mayflower, false Solomon's seal, starflower, blueberry, wild cranberry, round-leaf sundew, downy yellow violet, and sphagnum moss.

Principal breeding birds of this community include pileated woodpecker, yellow-bellied flycatcher, olive-sided flycatcher*, black-capped chickadee, red-breasted nuthatch*, winter wren*, hermit thrush, veery, solitary vireo, black-and-white warbler*, Nashville warbler, northern parula*, magnolia warbler*, yellow-rumped warbler*, ovenbird, northern waterthrush, common yellowthroat, brown-headed cowbird, purple finch*, pine siskin, chipping sparrow, white-throated sparrow, and song sparrow.

\section{Black Spruce-Tamarack Bog}

Although not as extensive in distribution as other coniferous or deciduous habitats, bogs are important to a large variety of breeding birds. This community exists primarily north of the Tension Zone and becomes frequent in the Northern Highland. Scattered relict bogs also occur in northern St. Croix and Washington counties. Bogs are formed in ancient lake basins or in outwash associated with morainal deposits. Bog soils are poorly developed and are usually highly acidic, owing in part to anaerobic decomposition of vegetation and temperature.

Black spruce and tamarack are the two most important tree species in this community. Mountain holly and bog birch are the main shrub layer species. Ground-layer vegetation in these bogs is perhaps the characteristic that separates this community from all others. Usually, the most important family is Ericaceae (e.g., leatherleaf, Labrador tea). Herbaceous vegetation in bogs usually contains several carnivorous plants including pitcher plant and round-leaf sundew. Prevalent vegetation includes Labrador tea, leatherleaf, bog rosemary, bog laurel, wild cranberry, buckbean, sphagnum moss, cottongrass, awned sedge, brown sedge, and bluejoint grass.

Principal breeding bird species include olive-sided flycatcher, blackcapped chickadee, red-breasted nuthatch, winter wren, veery, black-andwhite warbler, Nashville warbler*, yellow warbler, yellow-rumped warbler, common yellowthroat, red-winged blackbird, brown-headed cowbird, purple finch, pine siskin, American goldfinch, chipping sparrow, white-throated sparrow, swamp sparrow, and song sparrow. 


\section{Jack Pine Barrens}

This community exists throughout the northern portions of the Central Plain and Northern Highland. Extensive stands of Jack Pine Barrens occur on sandy soils associated with the bed of Glacial Lake Grantsburg in Burnett, Pine, and Polk counties. Curtis (1959) considered fire to be an important agent in the origin of Jack Pine Barrens. Soils are primarily sandy and stabilized by various grasses.

Principal tree species of Jack Pine Barrens include jack pine, red pine, Hill's oak, bur oak, large-toothed aspen, and trembling aspen. Sweet fern, New Jersey tea, and blueberry are the most important shrubs of this community. In many areas, blueberry becomes dominant over other shrubs and among the ground layer. Important ground-layer vegetation includes Canada bluegrass, Kentucky bluegrass, pearly everlasting, yarrow, bracken fern, dogbane, big-leaf aster, flowering spurge, whorled loosestrife, wintergreen, and bearberry.

Important breeding birds associated with Jack Pine Barrens are mourning dove, common flicker, blue jay, house wren, American robin, hermit thrush, yellow-rumped warbler, Nashville warbler, ovenbird, northern oriole, brownheaded cowbird, indigo bunting, rufous-sided towhee, chipping sparrow*, clay-colored sparrow, and field sparrow. Recent surveys indicate that the Connecticut warbler is a fairly common breeding species in localized areas of Jack Pine Barrens in northwestern and western Burnett County.

\section{Pine Plantations}

This artificial community has become an important avian habitat primarily in St. Croix and Washington counties. Large hectarages of cropland, hillsides, and Old Field Communities have been converted to Pine Plantations. The establishment of this community has accomplished three purposes: soil stabilization, ornamental plantings, and commercial Christmas tree production.

Pine Plantations are primarily monotypic stands of red pine and scotch pine. Occasional stands also include white pine. Size of these plantations usually range from 2 to 20 ha. During the early stages of establishment, ground-layer vegetation retains the character of the original habitat and can consist of Kentucky bluegrass, quackgrass, ragweed, bindweed, Virginia strawberry, and flowering spurge. Continued tree growth, low light, and increased soil acidity results in an almost complete lack of ground-layer vegetation development.

Principal breeding bird species include mourning dove*, blue jay, common crow, house wren, brown thrasher, American robin*, common grackle*, brown-headed cowbird, and chipping sparrow*.

\section{Wetland Communities}

\section{Prairie Wetlands}

Much of central St. Croix, southern Polk, north central Washington, and south central Chisago counties are dotted with small semipermanent and permanent wetlands. These wetlands occur on glacial outwash associated 
with the Wisconsin glacial epoch, which ended about 10,000 years ago. Upland soils associated with these wetlands are highly fertile loams and silt loams which are very important for agricultural production. Related to this, large hectarages of Prairie Wetlands have been drained or seriously altered to facilitate expanding agricultural production.

Principal emergent and submerged aquatic vegetation associated with these freshwater, low-acidity wetlands include hardstem bulrush, softstem bulrush, river bulrush, cattail, cane reed, spikerush, burreed, coontail, and water milfoil. Other important species dependent on water permanence and the degree of acidity include arrowhead, water plantain, and reed canary grass.

Characteristic breeding birds associated with Prairie Wetlands include pied-billed grebe*, American bittern*, Canada goose*, mallard*, gadwall*, pintail*, green-winged teal*, blue-winged teal*, ruddy duck*, Virginia rail*, sora*, American coot*, black tern*, tree swallow*, long-billed marsh wren*, yellow warbler, common yellowthroat, yellow-headed blackbird*, red-winged blackbird*, swamp sparrow, and song sparrow.

\section{Forest Bordered Wetlands}

Although similar to Prairie Wetlands in geologic origin, Forest Bordered Wetlands are different in flora and fauna. This community is widespread throughout the area north of the Tension Zone. Forest Bordered Wetlands are usually similar in size, but much deeper than Prairie Wetlands, and the interspersion of emergent and submerged aquatic vegetation is less pronounced. Acidity of the water in Forest Bordered Wetlands is generally greater than in Prairie Wetlands. Principal emergent and submerged aquatic vegetation associated with this community includes cattail, wild rice, iris, pickerelweed, arrowhead, water plantain, bladderwort, elodea, coontail, water milfoil, white waterlily, and yellow waterlily.

Characteristic breeding birds associated with these wetlands include common loon*, green heron, mallard, black duck*, wood duck, ring-necked duck*, hooded merganser, Virginia rail, belted kingfisher, tree swallow, long-billed marsh wren, yellow warbler, common yellowthroat, red-winged blackbird, brown-headed cowbird, swamp sparrow, and song sparrow.

\section{Riparian Habitats}

The streams and rivers of the Valley are well known for their recreational attractions. Among the important rivers are the Snake, Kettle, Willow, Apple, Clam, Namekagon, and Kinnickinnic. Numerous small streams that are tributaries of these larger rivers often provide excellent trout fishing. Breeding birds associated with streams and rivers may also be included in larger deciduous and coniferous communities. However, nesting strategies of several species are closely related to certain aspects of the ecology of moving water. Principal among these breeding birds are the great blue heron* (locally), mallard, wood duck*, hooded merganser*, spotted sandpiper*, belted kingfisher*, eastern phoebe*, rough-winged swallow*, cliff swallow*, American robin, yellow warbler, common yellowthroat, red-winged blackbird, and song sparrow. 


\section{Northern Sedge Meadow}

This community occurs throughout the Valley and makes up a large proportion of the aquatic habitats. These wetlands occur primarily north of the Tension Zone. Northern Sedge Meadow usually forms on the bed of an ancient lake or along and adjacent to larger streams and rivers. Soils associated with this community consist primarily of decaying vegetation and have a low mineral content. Groundwater is usually at or near the surface, providing a spongy texture to the soil surface. Probably the largest and best developed examples of Northern Sedge Meadow are associated with the bed of Glacial Lake Grantsburg in Burnett and Pine counties.

Principal vegetation of this community includes foxtail sedge, crested sedge, inland sedge, slender sedge, tussock sedge, fox sedge, cattail, bluejoint grass, manna grass, and dark-green bulrush. Important forbs include marsh cinquefoil, marsh milkweed, purple-stem aster, marsh bellflower, spotted joe-pye weed, meadow sweet, and small bedstraw.

Northern Sedge Meadows do not support the diversity and abundance of breeding birds usually associated with other wetland types. However, several species breed in this community almost exclusively. Principal breeding species include American bittern, mallard, marsh hawk*, ring-necked pheasant, sandhill crane*, sora, common snipe*, short-billed marsh wren*, yellow warbler, common yellowthroat*, red-winged blackbird, brown-headed cowbird, LeConte's sparrow* (local), swamp sparrow, and song sparrow.

\section{Alder Thicket and Shrub Carr}

Both Alder Thicket and Shrub Carr communities are similar in geologic origin and flora. One major difference between these habitats is that alder is replaced by willow, particularly silver willow, in Shrub Carrs. Both habitat types are usually associated with ancient lake beds or the floodplains of streams and rivers. In many instances, these habitats develop from the invasion of woody shrubs in a Northern Sedge Meadow. Alder Thicket and Shrub Carr communities occur regularly throughout the Valley. However, there appears to be a predominance of Alder Thickets north of the Tension Zone, and Shrub Carrs occur most frequently within and south of the Tension Zone.

Principal vegetation associated with the Shrub Carr community includes silver willow and red-osier dogwood in the shrub layer. Common grasses and forbs include marsh shield fern, yellowish sedge, bluejoint grass, reed canary grass, manna grass, marsh milkweed, jewelweed, spotted joe-pye weed, water horehound, and meadowsweet. Characteristic breeding birds of Shrub Carr include mallard, blue-winged teal, marsh hawk, ring-necked pheasant*, common snipe, willow flycatcher*, short-billed marsh wren, veery, yellow warbler*, common yellowthroat, red-winged blackbird, brown-headed cowbird, swamp sparrow, and song sparrow.

Vegetation associated with Alder Thicket habitat includes speckled alder and red-osier dogwood in the shrub layer. Characteristic grasses and forbs include dark-green bulrush, tall manna grass, bluejoint grass, marsh milkweed, marsh bellflower, turtlehead, spotted joe-pye weed, jewelweed, field mint, and great water dock. Characteristic breeding birds of Alder Thicket include alder flycatcher*, tree swallow, gray catbird, veery*, golden-winged 
warbler, yellow warbler, northern waterthrush* (local), common yellowthroat, red-winged blackbird, swamp sparrow*, and song sparrow.

\section{Agricultural Communities}

\section{Cropland}

One of the most prominent aspects of the landscape in the lower Valley is the presence of agricultural fields. According to figures from the U.S. Department of Agriculture, there were at least 158,540 ha in the Valley devoted to row crop or cereal crop production (row crop $=62.6 \%$, cereal crop $=37.4 \%$ ) in 1967 . By 1977 , the totals had increased to 195,587 total ha (73.2\% in row crops, $26.8 \%$ in cereal crops). Of the nearly 1.8 million ha of the Valley included in this report, $8.8 \%$ was devoted to row and cereal crop production in 1967 and $11 \%$ in 1977.

During the initial stages of agricultural development, important habitats including native tall grass prairie, deciduous forest, and prairie wetlands were destroyed to accommodate expanded production. Changes in land use of the magnitude attributed to Cropland have had a serious impact on bird populations and bird species diversity. Current agricultural practices of fencerow to fencerow farming, clean farming, fencerow removal, and windbreak removal to facilitate center-pivot irrigation systems, produce additional stresses on bird populations.

Corn, soybeans, oats, barley, and to a limited extent, wheat, are the prominent crops produced in this region. Although a common practice in western Minnesota, summer fallowing the soil has only recently become popular in this region. Characteristic breeding bird species that use Cropland include gray partridge*, killdeer*, horned lark*, western meadowlark, red-winged blackbird, and vesper sparrow.

\section{Hayland}

Domestic hay was produced on 128,927 ha in 1967 and 139,393 ha $(+7.5 \%)$ in 1977. Hayland accounted for 7.2 and $7.8 \%$ of the total area of the Valley in 1967 and 1977, respectively. This temporary habitat is important to a variety of early nesting species. Hayland is also important in soil conservation because the soil is not laid bare each year and is not exposed to the ravages of wind and water erosion as it is with row crops. Principal plant species used in hay production include alfalfa, timothy, brome grass, and red clover.

Characteristic breeding birds associated with Haylands include American bittern, mallard, blue-winged teal, pintail, marsh hawk, short-billed marsh wren, bobolink*, eastern meadowlark*, western meadowlark, red-winged blackbird, dickcissel*, savannah sparrow*, grasshopper sparrow*, Henslow's sparrow*, LeConte's sparrow, and song sparrow.

\section{Old Field Community}

The Old Field community represents a relatively small proportion of the land area in the Valley. This habitat type develops when land is taken out of agricultural production and allowed to develop by natural succession. Inva- 
sion by a variety of plants will result in a rapidly changing vegetational community. Areas of Old Field community are usually no larger than 16 ha; most are 4 to 8 ha.

Characteristic plant species associated with this habitat include a variety of pioneer trees and shrubs, such as trembling aspen, box elder, staghorn sumac, and flowering crab apple. Grasses and forbs associated with this habitat include timothy, awnless bromegrass, Kentucky bluegrass, quackgrass, big bluestem, little bluestem, hoary alyssum, blue vervain, moth mullein, yarrow, evening primrose, common milkweed, alfalfa, goat's beard, sheep sorrel, daisy fleabane, noble goldenrod, and sharp-toothed goldenrod.

Characteristic breeding birds associated with this habitat include American kestrel, mourning dove, eastern kingbird*, brown thrasher, eastern bluebird, golden-winged warbler, yellow warbler, eastern meadowlark, brownheaded cowbird, indigo bunting, American goldfinch, rufous-sided towhee, clay-colored sparrow*, field sparrow*, and song sparrow.

\section{Managed Grasslands}

Within the Valley, several thousand hectares of upland fields have been acquired by State and Federal conservation agencies as wildlife management areas or Waterfowl Production Areas. These lands are usually agricultural fields that have been taken out of production. Several different management techniques are used to develop extensive areas of grasses and forbs to provide nesting habitat for a variety of wildlife species.

Characteristic plant species established on Managed Grassland areas include intermediate wheatgrass, switchgrass, timothy, and brome grass. After establishment of these grasses, a number of forbs invade the areas. Several characteristic invaders include hoary alyssum, yarrow, blue vervain, daisy fleabane, and sharp-toothed goldenrod.

These established communities provide habitat for a variety of species including American bittern, mallard, pintail, blue-winged teal, marsh hawk, ring-necked pheasant, short-billed marsh wren, common yellowthroat, bobolink, eastern meadowlark, western meadowlark, red-winged blackbird, dickcissel, and savannah, grasshopper, Henslow's, vesper, and song sparrows.

\section{Residential Habitats}

Small towns and cities scattered throughout the Valley provide a diversity of habitats for breeding birds. Intermixed with concrete buildings are areas of hedgerows, row trees, tree groves, lawns, and parks. Diverse food sources, ranging from feed mills and lawns to gardens and bird feeding stations, add to the vegetation available for breeding birds.

Characteristic birds associated with Residential Habitats include rock dove*, mourning dove, screech owl, common nighthawk*, chimney swift*. downy woodpecker, purple martin*, blue jay, black-capped chickadee, whitebreasted nuthatch, house wren, gray catbird, brown thrasher, American robin, starling*, house sparrow*, northern oriole, common grackle, cardinal, rose-breasted grosbeak, and American goldfinch. 


\section{Methods, Terminology, and Nomenclature}

The counties covered in this report include Chisago, Pine, and Washington in Minnesota and Burnett, Douglas (part), Pierce, Polk, and St. Croix in Wisconsin. References made to a species status or occurrence in the Valley will pertain to these counties. Ideally, a complete coverage of the birds occurring in this region would include records for all counties within the watershed. However, because many records are not discernible to exact locations within a county (in or out of the watershed) I have, for conformity, included bird records only for counties that border on the St. Croix River.

Foremost among the published sources of data on bird occurrence and distribution presented in this report were the Loon and its predecessor, the Flicker, the quarterly publication of the Minnesota Ornithologists Union, and the Passenger Pigeon, the quarterly publication of the Wisconsin Society for Ornithology. Important papers dealing with species or species groups have been published in these journals and extensive use was made of the data contained therein. Considerable use was made of published reports in American Birds, the field report publication of the National Audubon Society. Probably the most important contribution of American Birds to the present report was the yearly publication of Christmas Bird Counts (CBC) conducted in both States.

I conducted field work in this region from 1966 through 1978, and intermittently during 1979-80. Before 1969 , most observations were made in northern Polk, southern Douglas, Burnett, and eastern Pine counties. During 1969-76, field work was expanded to include the remainder of the counties and intensive observations were started on several species in Pierce, St. Croix, and Washington counties. Many of the dates of occurrence and statements on abundance and distribution were derived largely from my unpublished field notes. The unpublished field notes of Rev. Samuel Robbins for 1960-68 in St. Croix, Polk, and Pierce counties were also examined extensively. Several State parks and wildlife management areas in both States were visited and some limited data (with the exception of the Crex Meadows Wildlife Area) were made available.

Data on breeding and winter status were gathered from three sources. First, intensive field work by several previous investigators and me led to the discovery of numerous nests or dependent young. These observations provide the foundation for species status remarks and habitat use of breeding birds. Secondly, the U.S. Fish and Wildlife Service, Migratory Bird and Habitat Research Laboratory, Laurel, Maryland, has established a number of BBS transects throughout North America (Robbins and Van Velzen 1967). These $39.2 \mathrm{~km}$ transect routes are selected at random and are censused once each year during June. Five transect routes were established in the Valley; unfortunately, all five are in Wisconsin (Fig. 4). Data from these routes are presented to point out regions of peak populations of several species and, in some instances, to show geographic differences in species breeding distribution. Third, CBC sponsored by the National Audubon Society provide an important source of data on winter bird populations and geographic differences in species abundance. At least eight CBC areas have been established within the Valley. However, only five (Fig. 5) have been 


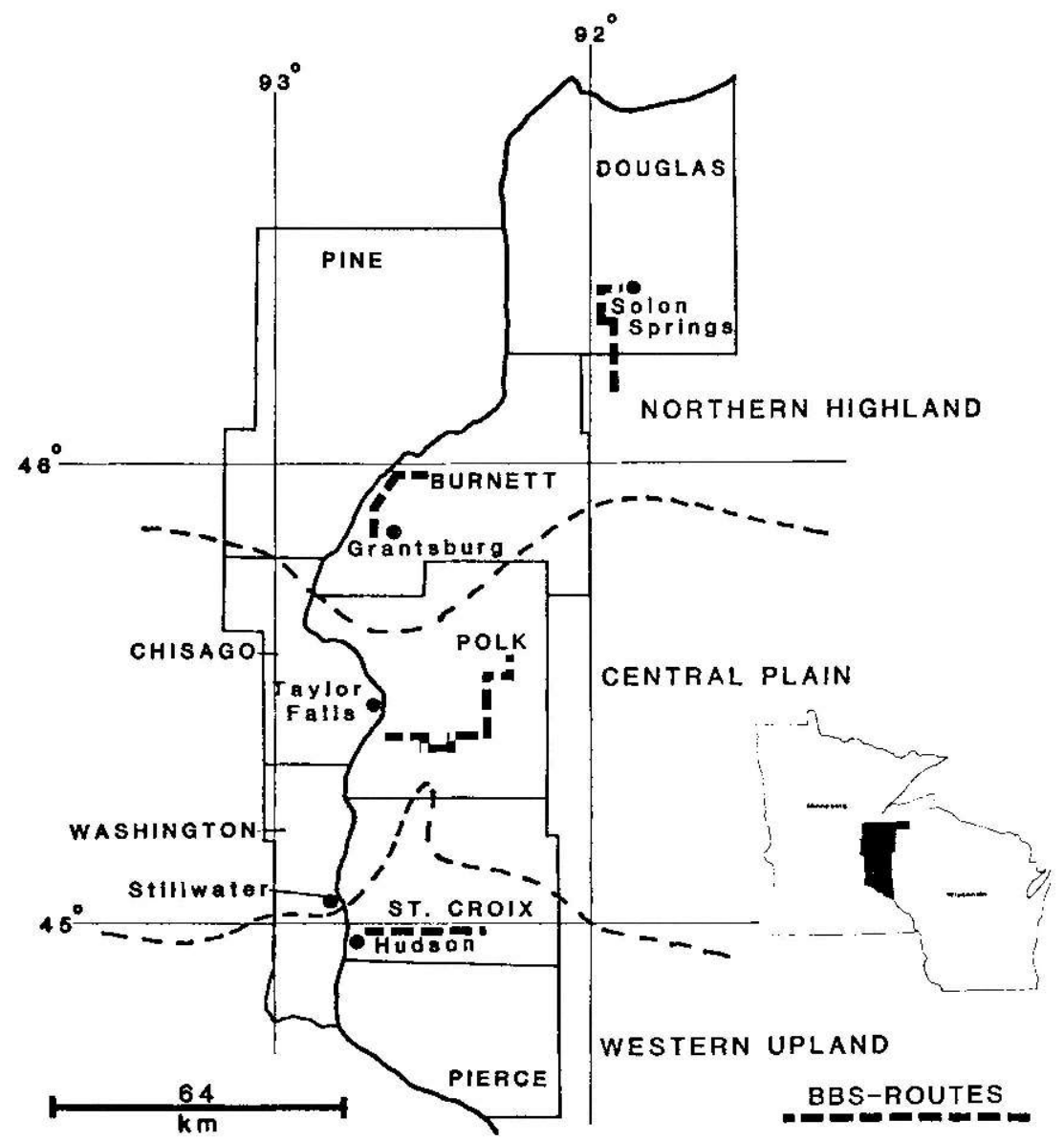

Fig. 4. Location of Breeding Bird Survey routes in the St. Croix River Valley.

counted for a sufficient number of years to allow meaningful comparisons.

\section{Terms}

Considerable conjecture and argument has developed about what is the best method for describing a species occurrence, regularity, and abundance. Terms are treated under three categories: status, season, and abundance. The terms used to describe each species status in the present report are adapted from those presented in Green and Janssen (1975), including Regular-A species that occurs at some location in the Valley during at least one season each year.

Casual-A species expected to occur at least once every 3 to 5 years, but not annually. 


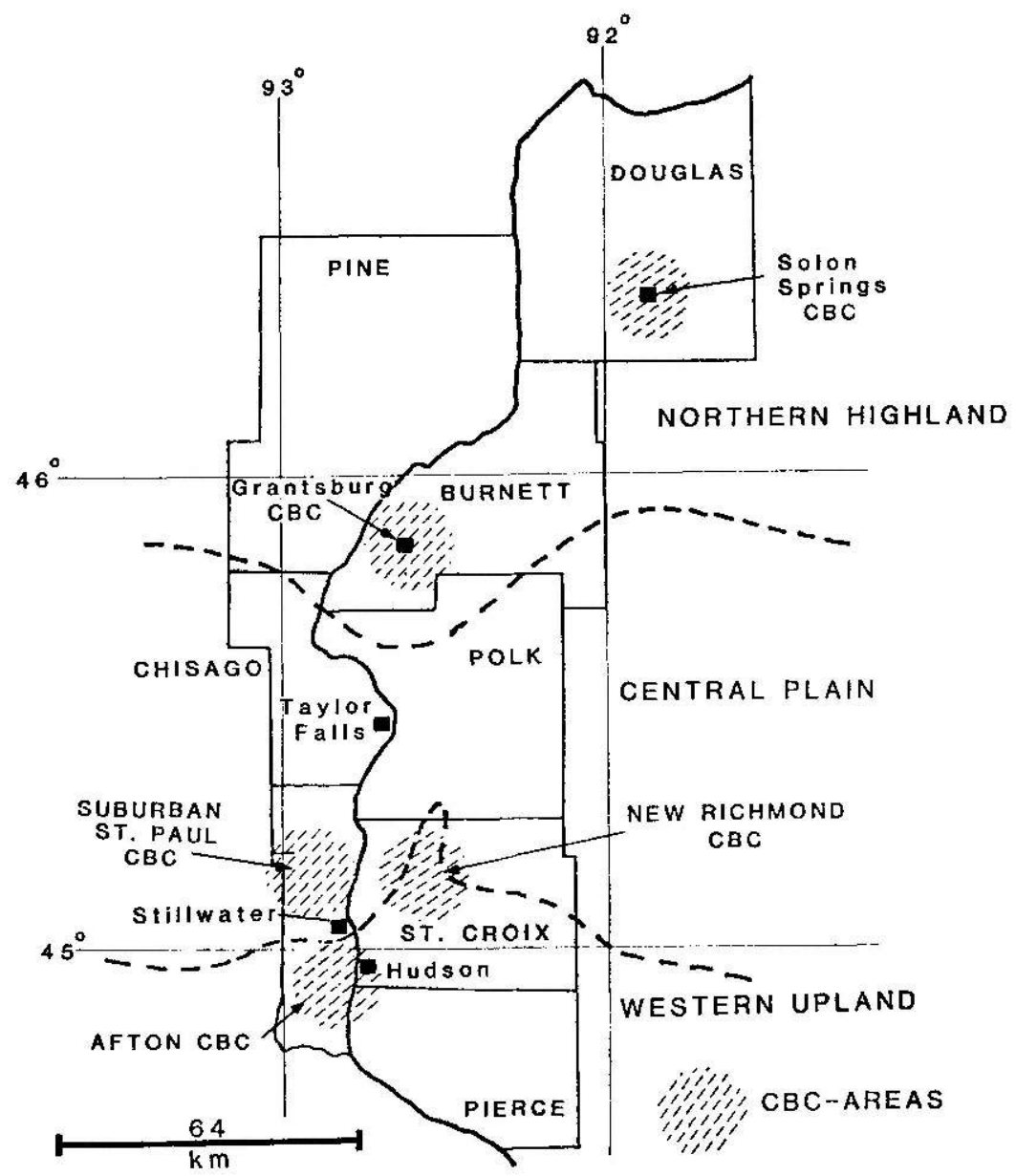

Fig. 5. Location of major Christmas Bird Count areas in the St. Croix River Valley.

Accidental-A species that is not expected to occur again or that occurs very infrequently.

Hypothetical-A species that probably occurred in the Valley at least once, but the circumstances of the observation leave the record in doubt.

Introduced-A species that is naturally foreign to this region but has been released in the area as an act man and is now established and reproducing without additional influence by man.

Extirpated-A species that once occurred naturally in the Valley, has now been eliminated, but still exists elsewhere. This term applies to both migrants and nesting species.

Extinct-A species that no longer exists anywhere on earth.

The population status of several species has recent.y become a concern of the public. Legal protection for all birds except the ro k dove, starling, and 
house sparrow has been provided by the Federal Government by the Migratory Bird Treaty Act of 1918, as amended (40 Stat. 755; 16 U.S.C. 703-711). Eagles have been afforded additional protection by the Eagle Act of 1940 (54 Stat. 250; 16 U.S.C. 668). Several species have been given even greater protection by the Federal Endangered Species Act of 1973 (87 Stat. 884; 16 U.S.C. $668 \mathrm{aa}-668 \mathrm{cc}$ ). Both Minnesota and Wisconsin have enacted special legislation within their respective States that provides statewide protection for species that are declining locally or regionally, but not on a level to be afforded protection by the Endangered Species Act of 1973.

Official lists of protected bird species have been prepared for Minnesota and Wisconsin. Forty-three of the species listed by either State have been recorded in the Valley (Table 1). Terms used throughout this report to describe the special status of these species are adapted from Les (1979) and Moyle (1980).

Endangered-A species whose continued existence is in jeopardy and is provided special protection by law.

Threatened-A species that appears likely to become endangered. Threatened species are provided special protection by law.

Watch-A species for which some problem of abundance is suspected but not proven. The purpose of this classification is to focus attention on a species before it becomes threatened or endangered. This is an informal classification and no additional legal protection is provided. In Minnesota, species in this classification are considered Priority.

Terms used in describing the occurrence of a species in the Valley include

Permanent resident-A species that is largely nonmigratory or, if migratory, only a very small proportion of the population departs during a migration period.

Migrant-A species that normally occurs in the Valley only during the well-defined spring and fall migration period.

Nesting species-A species for which a viable clutch of eggs, dependent young in the nest, or young that have left the nest but are still dependent have been observed.

Summer resident-A species that occurs in the Valley during the normal nesting period and in all likelihood nests, but for which there are no confirmed records of eggs or dependent young.

Winter resident-A species that winters even though greater numbers may occur during migration.

Terms used in relating the relative abundance of each species during migration, winter, or the breeding season relate to its importance to the total avifauna. These terms adapted from Stewart (1975) are described as follows:

Abundant-A species that, because of its habits and conspicuousness, occurs in very large numbers.

Common-A species that occurs in large numbers.

Fairly common-A species that occurs in fair to moderate numbers.

Uncommon-A species that is found in low numbers. 
Table 1. Endangered (E), threatened $(T)$, priority $(P)$, and watch $(W)$ species in the St. Croix River Valley.

\begin{tabular}{|c|c|c|}
\hline Species & Minnesota & Wisconsin \\
\hline Common loon & & W \\
\hline White pelican & $\mathbf{P}$ & \\
\hline Double-crested cormorant & & E \\
\hline Great egret & & $\mathrm{T}$ \\
\hline Snowy egret & $\mathrm{P}$ & \\
\hline Great blue heron & & W \\
\hline Black-crowned night heron & & W \\
\hline Yellow-crowned night heron & $\mathbf{P}$ & \\
\hline Black duck & & W \\
\hline Red-breasted merganser & & W \\
\hline Cooper's hawk & & $\mathrm{T}$ \\
\hline Marsh hawk & $\mathbf{P}$ & W \\
\hline Red-shouldered hawk & & $\mathrm{T}$ \\
\hline Bald eagle & $\mathrm{T}$ & $\mathbf{E}$ \\
\hline Osprey & & $\mathrm{E}$ \\
\hline Peregrine falcon & $\mathbf{E}$ & $\mathbf{E}$ \\
\hline Merlin & $\bar{P}$ & $\mathbf{W}$ \\
\hline Spruce grouse & & W \\
\hline Sharp-tailed grouse & & W \\
\hline Greater prairie chicken & $\mathbf{P}$ & $\mathrm{T}$ \\
\hline Bobwhite & $\mathrm{T}$ & \\
\hline Yellow rail & $\mathbf{P}$ & W \\
\hline King rail & $\mathrm{T}$ & \\
\hline American avocet & $P$ & \\
\hline Piping plover & $\mathrm{T}$ & $\mathbf{E}$ \\
\hline Marbled godwit & $\mathbf{P}$ & \\
\hline Upland sandpiper & $\mathbf{p}$ & w \\
\hline Common tern & $\mathbf{P}$ & $\mathrm{E}$ \\
\hline Forster's tern & & $\mathbf{E}$ \\
\hline Caspian tern & & $\mathbf{w}$ \\
\hline Black tern & & W \\
\hline Great gray owl & $\mathrm{T}$ & \\
\hline Short-eared owl & $\mathbf{P}$ & \\
\hline Common flicker & & $\mathbf{w}$ \\
\hline Black-backed three-toed woodpecker & $\mathbf{P}$ & \\
\hline Bewick's wren & & $\mathbf{w}$ \\
\hline Eastern bluebird & $\mathbf{P}$ & W \\
\hline Loggerhead shrike & & $\mathrm{T}$ \\
\hline Dickcissel & & $\mathrm{W}$ \\
\hline Grasshopper sparrow & & $\mathrm{W}$ \\
\hline Baird's sparrow & $\mathbf{P}$ & \\
\hline Sharp-tailed sparrow & $\mathrm{P}$ & \\
\hline Vesper sparrow & & W \\
\hline Field sparrow & & W \\
\hline
\end{tabular}

Rare-A species whose range includes the Valley but is recorded in low numbers.

Very rare-A species that occurs in such low numbers that it is of minor importance. 
Table 2. Classification of wetland types in the St. Croix River Valley. This classification follows Cowardin et al. (1979) and Curtis (1959).

\begin{tabular}{lcccc}
\multicolumn{1}{c}{$\begin{array}{c}\text { Wetland name } \\
\text { used in } \\
\text { this report }\end{array}$} & $\begin{array}{c}\text { Wetland type } \\
\text { (Shaw and } \\
\text { Fredine 1956) }\end{array}$ & $\begin{array}{c}\text { Water } \\
\text { chemistry }\end{array}$ & Authority \\
\hline Temporarily flooded & 1 & Fresh & Cowardin et al. \\
Northern sedge meadow & 2 & Fresh & Curtis \\
Seasonally flooded & 3 & Fresh & Cowardin et al. \\
Semipermanently flooded & 4 & Fresh & Cowardin et al. \\
Permanently flooded & 5 & Fresh & Cowardin et al. \\
Shrub carr & 6 & Fresh & Curtis \\
Bog & 8 & Acidic & Curtis & \\
\hline
\end{tabular}

\section{Nomenclature}

The taxonomic treatment of birds presented in this report follows the American Ornithologists' Union (AOU) Check-list of North American Birds (1957), and the 32nd (AOU 1973) and 33rd (AOU 1976) supplements to the Check-list. One deviation from the AOU standard sequence is presented for the shorebirds. In this instance, I followed the sequence recommended by Jehl (1968).

Description of the major plant communities of the Valley follows Curtis (1959). Major habitats used by each species were determined from personal field investigations and from published reports. The taxonomic names of plants described in the habitat sections are those used in Gleason and Cronquist (1956). Common names of some plant species, primarily grasses and sedges, are taken from Britton and Brown (1913). Voucher specimens of most of the important grasses and forbs used in this report are housed in the Herbarium, Department of Biology, University of Wisconsin-River Falls.

The wetland classification used in this report (Table 2) is a combination of the systems developed by Cowardin et al. (1979) and Curtis (1959). Cowardin et al. (1979) employ a hierarchical system with modifiers for water regime, water chemistry, and soil type. Three wetland types (Northern Sedge Meadow, Shrub Carr, and Bogs) were named and classified by Curtis (1959). Because these names are widely used and accepted in the Valley, I have deviated from Cowardin's system in that instance.

\section{Species Accounts}

\section{FAMILY GAVIIDAE: Loons}

\section{Common Loon (Gavia immer)}

Status: Regular migrant and nesting species.

Migration: Common (locally abundant) during spring and fall throughout the Valley. Spring migrants arrive in the Western Upland during the first 
week of April (earliest-4 April 1964, St. Croix County; Soulen 1965) and the Northern Highland 10-15 April. Peak spring abundance occurs 20 April to 1 May. During this period flocks of 5 to 10 birds are common and flocks totaling 15 to 20 are occasional on larger lakes. Spring departure from the southern one-third of the Valley occurs by 15 May. Fall migrants arrive in the Western Upland during the first week of October and remain until water on the larger lakes freezes in late November. No major common loon staging areas exist in this region, resulting in relatively small numbers observed during the fall.

Nesting Season Distribution: Uncommon nesting bird on larger lakes and marshes of the Northern Highland, rare and local in the Central Plain. Casual summering birds near Roberts, St. Croix County, indicate possible nesting although no broods have been observed. Longley (1949) reported a pair with one young in Washington County on 17 June 1949. Additional Washington County brood records were obtained in 1970 and 1971 (Eckert 1971).

Habitat: Common loons are primarily a species of large permanently flooded wetlands, particularly those containing small islands. Most wetlands used for nesting are bordered by deciduous forest, chiefly trembling aspen and maple, and contain peripheral zones of emergent aquatic vegetation. At the Crex Meadows Wildlife Area in Burnett County, common loons nest on semipermanently and permanently flooded wetlands. The vegetation consists primarily of cattail and various species of sedge. Evrard et al. (1978) found that common loons at Crex Meadows occupied wetlands that ranged from 6.9 to 324 ha.

Concern has been expressed recently about the population status of this species in Wisconsin, Minnesota, and other northern States. The primary threat to the nesting habitat of this species is shoreline development surrounding nesting lakes.

\section{Red-throated Loon (Gavia stellata)}

Status: Casual migrant; one summer record.

Records: Spring records include Pierce County-10 May 1967; St. Croix County-25 April 1962 and 17 May 1965; Burnett County-15 May 1950 (Robbins 1950b). During the summer of 1953 a nonbreeding red-throated loon was observed on 11 June and 17 July at Crex Meadows Wildlife Area, Burnett County.

\section{FAMILY PODICIPEDIDAE: Grebes}

\section{Red-necked Grebe (Podiceps grisegena)}

Status: Regular migrant and nesting species.

Migration: Rare spring and fall migrant in the Western Upland, casual or absent elsewhere. Spring migrants arrive during the second week of April (earliest-8 April 1959, Burnett County). Dates of peak abundance cannot 
be determined because of low numbers. Nonbreeding migrants have departed by 20 May. The first fall migrants arrive 25 September to 5 October and the last depart by 1 November (latest-10 November). During both seasons migrants are usually observed in central St. Croix County and at several areas along the St. Croix River in Washington, Polk, and St. Croix counties.

Nesting Season Distribution: The red-necked grebe is a very rare and local nesting species. Green and Janssen (1975) showed a nesting record for Washington County. Apparently this species no longer nests on the Minnesota side of the St. Croix River. Presently, nesting occurs only on prairie wetlands in central St. Croix and extreme southern Polk counties.

The first nesting for the Valley in Wisconsin was recorded in 1973 from East Twin Lake near Roberts. During the summer of 1976, three pairs produced young on Twin Lakes and an additional pair was successful on Oakridge Lake near New Richmond. In 1977, four pairs produced young on Oakridge Lake, one pair on East Twin Lake, and a sixth pair produced young on a small wetland near Star Prairie in Polk County. During 1978-79 breeding populations were greatly reduced with activity restricted to Oakridge Lake (M. Schmidt, personal communication).

Habitat: All 12 nesting records have been obtained on semipermanently and permanently flooded wetlands. These wetlands range in size from 8.5 to $93 \mathrm{ha}$. Extensive beds of submerged aquatic plants are present on these wetlands. All nests have been located in large beds of softstem bulrush.

\section{Horned Grebe (Podiceps auritus)}

Status: Regular migrant, casual nesting species.

Migration: Common migrant throughout the Valley. Spring migrants begin to arrive in the Western Upland during the second week of April (earliest$24 \mathrm{March}$ ) and the Northern Highland 1-5 May. Peak abundance occurs during the first week of May and departure by 15 May. Fall migrants begin to arrive during the third week of September. Peak abundance occurs about 15 October when occasional flocks of 50 to 60 individuals are observed on larger lakes. Fall migrants have departed by November 20 .

Nesting Season Distribution: One nesting record exists for this region. On 2 July 1951 an adult with a brood of four was observed at the Crex Meadows Wildlife Area, Burnett County. On 14 June 1974, I observed an adult in breeding plumage near Range, Polk County.

Habitat: Horned grebes use a wide range of wetland classes including seasonally, semipermanently, and permanently flooded wetlands. In the Northern Highland, extensive use is made of Forest Bordered Wetlands and occasional use is made of acidic bog wetlands and larger rivers. The Burnett County nesting pair were using a large sedge meadow wetland.

\section{Eared Grebe (Podiceps nigricollis)}

Status: Regular spring and casual fall migrant; four summer records. 
Migration: Rare migrant in the Western Upland and Central Plain. There are no records except from Crex Meadows in the Northern Highland. Spring migrants begin to arrive during the last week of April (earliest-20 April 1975, Polk County) and remain through 5 June. Sightings are most often of single or paired birds. Dates for fall migrants are too few to establish a pattern. Fall observations are rare, noted between 10-20 September.

Nesting Season Distribution: One nesting record exists for the Valley. S. D. Robbins found an adult carrying young on its back during the summer of 1968 on East Twin Lake near Roberts, St. Croix County (Robbins 1969a). This is the only known nesting record of the eared grebe in Wisconsin. On 21 July 1952, three eared grebes were observed on Phantom Lake, Crex Meadows, and on 12 July 1956, a single bird was observed at Crex Meadows (Lound and Lound 1956b). During the summer of 1977, a single adult remained on Oakridge Lake, St. Croix County, until 8 August.

Habitat: Eared grebes in the Valley have been found primarily on large permanently flooded wetlands with extensive growths of emergent and submerged aquatic vegetation. The St. Croix County nesting pair used a large semipermanently flooded wetland. Vegetation of that wetland was characterized by extensive beds of coontail surrounded by hardstem bulrush and cattail.

\section{Western Grebe (Aechmophorus occidentalis)}

\section{Status: Casual migrant.}

Records: Western grebes have been observed twice in spring and once in fall at Crex Meadows, Burnett County. The first record was 30 May 1974, and the second 8 June 1976. The fall observation was on 26 August 1975. All Crex Meadows records were obtained from the Phantom Lake flowage. J. $O$. Evrard observed a single western grebe on the Fish Lake Wildlife Area near Grantsburg, Burnett County, on 3 June 1979. This bird was observed on Crex Meadows on 11 June 1979 (Tessen 1979b). This species has been recorded three times in St. Croix County: 2 October 1976, two birds on Oakridge Lake near New Richmond; 6 October 1967, three birds on Cedar Lake near Star Prairie; and 12 October 1974, on Oakridge Lake.

\section{Pied-billed Grebe (Podilymbus podiceps)}

Status: Regular migrant and nesting species.

Migration: Common migrant throughout the Western Upland and Central Plain, fairly common in the Northern Highland. Spring migrants arrive during the last week of March (earliest-9 March 1957, Burnett County). Peak abundance occurs 20 April to 1 May. During peak migration, concentrations of 75 to 100 individuals occur on several larger lakes in Chisago, Polk, and Burnett counties. Fall migrants begin to concentrate in early September. Peak fall abundance occurs during the second week of October and departure by 10 November (latest-19 December 1974, Pierce County). 
Nesting Season Distribution: Common nesting species throughout the Valley. The largest numbers occur on prairie wetlands of the Central Plain and in the extensive marshes of southwestern Burnett County.

Habitat: The pied-billed grebe occurs most commonly on seasonally and semipermanently flooded wetlands with lush stands of emergent aquatics; cattail and bulrush appear to be preferred for nesting. Nesting pied-billed grebes are also found on large permanently flooded and Alder Thicket wetlands in the Northern Highland. Breeding populations in these habitat types are lower than on seasonally or semipermanently flooded wetlands.

\section{FAMILY PELECANIDAE: Pelicans}

\section{White Pelican (Pelecanus erythrorynchos)}

\section{Status: Casual migrant.}

Distribution: White pelicans have been observed in the Valley at least 10 times: St. Croix County-28-30 April 1941 (Schorger 1954), May 1950, and 2-6 November 1975 (Lesher 1976). Polk County-23 April 1867 (Schorger 1954), and 24 April to 12 June 1947. Burnett County-10 July 1970 (Crex Meadows files), and 30 October 1883 (Schorger 1954). Washington County16 April 1976. Chisago County-about 60 white pelicans were observed migrating upstream at Taylor's Falls on 14 April 1979 (Turner 1979). Pine County-18 September 1972 (M. Link, personal communication).

Habitat: Most records of white pelicans have been of birds using large lakes, man-made impoundments, or open stretches of the St. Croix River.

\section{FAMILY PHALACROCORACIDAE: Cormorants}

\section{Double-crested Cormorant (Phalacrocorax auritus)}

Status: Regular migrant and nesting species. The Wisconsin Department of Natural Resources (WDNR) has listed this species as endangered (Les 1979). Loss of nest trees, use of pesticides, and human disturbance are listed as reasons for their decline.

Migration: Rare and local migrant throughout the Valley. Formerly a common to abundant migrant throughout its range, populations of doublecrested cormorants have experienced alarming declines. Records exist of "flocks of thousands" migrating north along the Mississippi and St. Croix rivers until the 1950's. Currently, observers are fortunate to find more than 25 individuals during the year. The average date of spring arrival is 18 April (earliest-4 April 1976, Chisago County). Peak spring migration occurs 25 April to 10 May, and departure from nonbreeding areas by 25 May. Peak fall migration occurs between 10-20 September and departure by 15 October (latest-3 November 1975, Burnett County).

Nesting Season Distribution: Double-crested cormorants are rare and local during the nesting season in this region, currently known to nest only at the Crex Meadows and Fish Lake Wildlife Areas in Burnett County. The first 
nesting was noted at Crex Meadows in 1968. This colony was in a heron rookery on Phantom Lake. Because of degredation of nesting trees, the Phantom Lake colony declined, and birds moved to the Grettum Flowage at Fish Lake Wildlife Area. In 1973, 23 nests were observed in the Grettum Flowage colony.

Habitat: Both Phantom Lake and Grettum Flowage are large impoundments characterized by deep water and dead trees. This temporary habitat type was created when tree growth in these basins was inundated by rising impounded waters. Construction of nest platforms in the Phantom Lake colony has attracted several breeding pairs. This management practice may prove essential in the maintenance of these two colonies.

\section{FAMILY ARDEIDAE: Herons and Bitterns}

\section{Great Blue Heron (Ardea herodias)}

Status: Regular migrant and nesting species, casual winter resident.

Migration: Common migrant in the Western Upland and Central Plain, uncommon and local in the Northern Highland. Spring migrants arrive in the Western Upland about 10 March (earliest-1 March 1969, St. Croix County) and reach the Northern Highland by 1 April. Peak migration occurs 5-20 April. Fall migration begins in mid-July with the gradual dispersal of young from rookeries. Peak fall migration occurs 25 August to 30 September and most depart by 10 November (latest-20 November 1964 and 9 December 1971, Burnett County).

Nesting Season Distribution: Fairly common and local nesting species throughout the Valley. Evidence of nesting has been documented in all counties except Pierce. The two largest rookeries in the region are at Crex Meadows Wildlife Area, Burnett County, and at Pine Lake, Pine County. At least four rookeries were active in Burnett County in the late 1940's and early 1950's (Williams 1957). The Crex Meadows rookery located on Phantom Lake was first used in 1952 (Williams 1957). Further records related to the breeding population of this rookery follow:

$1958-157$ active nests

$1960-108$ active nests

$1962-109$ active nests

$1968-160$ active nests. Rainstorm $(8.5 \mathrm{~cm})$ on 30 June left 65 nests in the

rookery. About 150 herons were found dead near the rookery.

1973-169 active nests, Phantom Lake; 13 active nests, North Fork Flowage

1974-143 active nests in four rookeries

$1975-75$ active nests in the Phantom Lake rookery

$1976-31$ active nests

Deterioration of nest platform trees is the primary cause of the rookery decline at Crex Meadows. Attempts at placing artificial nest platforms for great blue herons on the Phantom Lake rookery have been successful in attracting double-crested cormorants. However, the great blue herons have 
not reestablished to former levels.

Winter: Three winter records exist for St. Croix County: 2 January 1961; 1 January 1971; and 1 January 1972. All birds were recorded on the Afton CBC.

Habitat: Most nesting rookeries in this region exist as small colonies built on dead or dying deciduous trees near natural lakes. The Burnett County colonies are in decaying trees associated with man-made impoundments. As evidenced by the continual changes in colony size and location of breeding populations at Phantom Lake, these temporary habitats are in a constant state of deterioration. In the Western Upland, several small rookeries exist in living green ash and American elm associated with the Lowland Deciduous Forest community. One rookery in the Northern Highland is in living white pine trees close to the St. Croix River in Burnett County.

\section{Green Heron (Butorides striatus)}

Status: Regular migrant and nesting species.

Migration: Common migrant in the Western Upland, primarily on the prairie wetlands of St. Croix, Washington, and southern Polk counties. Fairly common in the Central Plain, and uncommon and local in the Northern Highland. Spring migrants begin to arrive during the last week of April (earliest-6 April 1975 and 12 April 1964, Washington County). Average date of first arrival in Burnett County is 10 May, reaching Douglas County by 15 May. Peak spring abundance occurs 5-20 May. Fall migration begins in mid-August with formation of loose flocks. Peak fall movements occur 1-15 September. Green herons depart the Northern Highland by 15 September and the Western Upland by 10 October (latest-27 October 1975 and 9 November 1965, Washington County).

Nesting Season Distribution: Fairly common nesting species in the Western Upland, particularly the prairie wetland region of St. Croix, Washington, and southern Polk counties. Uncommon in the Central Plain, and rare and local in the Northern Highland. Substantial breeding populations occur in the marshes of Glacial Lake Grantsburg in Burnett County. Roberts (1932) cited a June 1919 nest containing three young in Pine County. Documented breeding records exist for all counties in the river valley except Chisago and Douglas. Jackson (1941) failed to record this heron during the 1919 breeding season in northwestern Wisconsin.

Habitat: Breeding green herons utilize a variety of habitats for nesting. In the Western Upland, breeding pairs and nests are typically observed in seasonally, semipermanently, and permanently flooded wetlands, and riverine habitats. In the Central Plain, breeding green herons are found typically in seasonally and semipermanently flooded wetlands, but also occupy Shrub Carr wetlands with a scattering of open water areas.

\section{Little Blue Heron (Florida caerulea)}

Status: Accidental, one record. 
Record: One adult was seen near Dunroven, Washington County, on 23 April 1962 (Huber 1962). Because of the recent noticeable expansion of this species in the upper Midwest, I would expect this species to be recorded more regularly in the future.

\section{Cattle Egret (Bubulcus ibis)}

\section{Status: Casual migrant.}

Records: The first cattle egret record for the Valley was obtained in Chisago County on 7 May 1971, when six birds were observed. One was observed in Washington County on 25 April 1977 (Savaloja 1977). In Pierce County a single bird was observed near River Falls on 28 April 1976. At Crex Meadows, Burnett County, groups of four birds each were observed on 24-28 May 1974 and 16 April 1976. J. O. Evrard reported that cattle egrets were present during July 1979 at Crex Meadows (Tessen 1979b).

\section{Great Egret (Casmerodius albus)}

Status: Regular migrant and nesting species. The Wisconsin DNR has listed this species as threatened (Les 1979). Wetland drainage, loss of mature nest trees, pesticides, and human disturbance are listed as reasons for the decline.

Migration: Uncommon migrant in the Western Upland, rare and local in the Central Plain. Except in the vicinity of Crex Meadows, Burnett County, this species is rare north of a line extending from Chisago to northeastern St. Croix counties. First spring migrants arrive in the Western Upland 10-15 April (earliest-29 March 1968) and in Burnett County about 20 April. One Polk County record was obtained on 10 April 1970. Fall migration begins in mid-August. Peak fall populations occur 25 August to 10 September and departure by 10 October (latest-30 October 1970 and 31 October 1956, Burnett County).

Nesting Season Distribution: Rare and local nesting species with documented breeding records from Washington, St. Croix, and Burnett counties. Establishment of this bird as a breeding species has been fairly recent. Jackson (1941) failed to observe great egrets during 1919 in northwestern Wisconsin. Roberts (1932) described the great egret as "occasionally a straggler from the south," yet cites no records from the Minnesota counties. The first record for the Valley is provided by King (1949), who reported this species at Prescott, Pierce County, in 1946. Great egrets were first reported at Crex Meadows, Burnett County, in 1948. Later, summer observations ranged from 19 in 1956 to 1 in 1969. Nesting at Crex Meadows was first recorded on 25 June 1975 (Evrard 1975). Since 1975, a small nesting colony has remained on the Fish Lake Wildlife Area, Burnett County. In Washington County, nesting has been established with a colony of undetermined size (Green and Janssen 1975). St. Croix County breeding records were established in 1976 when two young were seen feeding with adults along Ten Mile Creek on 11 July. These birds nested in a small great blue heron colony along the 
Willow River near New Richmond.

Habitat: Washington and St. Croix county colonies exist in live trees of Lowland Deciduous Forest. Nests at Fish Lake Wildlife Area occur in jack pine trees killed by the rising waters of Grettum Flowage.

\section{Snowy Egret (Egretta thula)}

Status: Accidental, one record.

Record: Norman Stone observed a single snowy egret at Crex Meadows, Burnett County, on 4 and 5 May 1959 (Stone 1959a).

\section{Louisiana Heron (Hydranassa tricolor)}

Status: Accidental, one record.

Record: One Louisiana heron was observed at Crex Meadows, Burnett County, on 7 July 1977 (Tessen 1977).

\section{Black-crowned Night Heron (Nycticorax nycticorax)}

Status: Regular migrant and nesting species.

Migration: Uncommon and local migrant in the Western Upland, rare in other regions. Spring migrants arrive in the Western Upland 10-15 April, reaching peak abundance 1-10 May. Average date of spring arrival in Burnett County is 10 May. Fall migration begins 25 August to 1 September and departure by 1 October (latest-28 November 1967, Washington County).

Nesting Season Distribution: Rare and local nesting species. Confirmed breeding records have been reported only from St. Croix and Burnett counties; however, several summer observations have been made in Washington County. Roberts (1932) stated that one of the most northerly colonies in Minnesota occurred on the St. Croix River in Pine County. Unfortunately no dates or locations are provided.

Habitat: Three nesting colonies of black-crowned night herons are known in this region. Habitats associated with these colonies include wetland habitat dominated by bulrush and cattail. In proximity are small groves of alder and willow used for nest platforms.

\section{Yellow-crowned Night Heron (Nyctanassa violacea)}

Status: Accidental, one record.

Record: Green and Janssen (1975) cite a 6 June 1964 record from St. Croix State Park, Pine County.

\section{Least Bittern (Ixobrychus exilis)}

Status: Regular migrant and nesting species. 
Migration: Uncommon migrant in the Western Upland and Central Plain. First spring migrants arrive 5-10 May and are most frequently observed 20-25 May. Fall migration begins 15-25 August and departure by 25 September.

Nesting Season Distribution: Uncommon nesting species in the Western Upland, uncommon to rare and local in the Central Plain. Documented breeding records exist for St. Croix County (three nests), Polk County (one nest), and Burnett County (one nest). Summer observations of adults in Chisago and Washington counties provide inferred evidence of nesting in those counties.

Habitat: Principal nesting habitat of the least bittern includes semipermanently and permanently flooded wetlands. Nests observed in St. Croix and Polk counties were in extensive stands of hardstem bulrush and river bulrush. The Burnett County nest was in a mixed stand of cattail and river bulrush.

\section{American Bittern (Botaurus lentiginosus)}

Status: Regular migrant and nesting species, accidental in winter.

Migration: Fairly common spring and fall migrant in the Western Upland and Central Plain, uncommon and local in the Northern Highland. Spring migrants arrive 10-20 April (earliest-4 April 1974, Burnett County), reaching peak abundance 1-5 May. Fall migration begins about 15 August in the Northern Highland and 25 August to 1 September elsewhere. Peak numbers occur 1-20 September. Departure from the Northern Highland occurs 20 September to 1 October; departure elsewhere is 10-25 October.

Nesting Season Distribution: Fairly common and well distributed in all regions. Breeding pairs occur with greatest frequency in the prairie wetland region of St. Croix, Polk, and Washington counties, and at Crex Meadows, Burnett County. Documented nest records exist for St. Croix, Polk, Burnett, and Washington counties. Evidence of nesting exists for the remaining counties. Jackson (1941) reported flushing one American bittern from a marsh at the headwaters of the St. Croix River in Douglas County on $8 \mathrm{Au}$ gust 1919.

Winter: Wayne Norling observed a single bird at Crex Meadows, Burnett County, on 9 January 1976.

Habitat: American bittern breeding habitat use varies with geographic province. Typical breeding habitat in Western Upland includes seasonally, semipermanently, and permanently flooded wetlands. Vegetation associated with these wetlands includes river bulrush, cattail, softstem bulrush, hardstem bulrush, and phragmites. Preferred habitat in the Central Plain is similar with a higher percentage of reed canary grass in seasonally flooded wetlands. Occasionally this species uses upland fields including Haylands, oat fields, Managed Grasslands, and retired cropland for nesting. In the northern regions of the Central Plain and throughout the Northern Highland, breeding habitat includes cattail-bulrush marshes. A high percentage of 
breeding pairs occur in sedge meadows in this region, as well as edges of Black Spruce-Tamarack Bog and northern Forest Bordered Lakes.

\section{FAMILY ANATIDAE: Swans, Geese, and Ducks}

\section{Whistling Swan (Olor columbianus)}

Status: Regular migrant, two summer records.

Migration: Common to locally abundant spring migrant in the Western Upland, fairly common in the Central Plain and uncommon in the Northern Highland. Spring migrants arrive about 25 March in the Western Upland and by 15 April in the Northern Highland. Peak spring migration occurs 10-25 April. During this period, flocks of 300 to 400 birds are frequently observed, primarily on the prairie wetlands of St. Croix and Washington counties. Roberts (1932) cited the passage of about 2,000 whistling swans through the Valley during "the spring of 1923." Departure is very rapid; most birds are gone by 10 May (latest-13 May 1975, Burnett County).

Fall migration begins with the arrival of the first birds in the Northern Highland about 5 October. Small groups of swans slowly move into the region during most of October. Peak fall migration occurs 25 October to 15 November. Currently, peak concentrations range from 100 to 300 indi. viduals. Roberts (1932) described the observation of "several mixed flocks of swans and geese, one numbering 1,200 to 1,500 birds" at Stillwater. Dates of peak numbers vary considerably and are dependent upon the advancement of northern cold fronts. Departure from the region usually occurs by $1 \mathrm{De}$. cember and is dependent upon the amount of ice formed on area waters.

Summer: A lone whistling swan was observed at Crex Meadows, Burnett County, on 26 June 1957 (Lound and Lound 1957d). A single bird remained in St. Croix County during the 1979 summer (Tessen 1979b). Both birds were probably injured.

Habitat: Migrant whistling swans utilize a variety of wetland types during migration. In spring, whistling swans are usually found feeding in numerous temporarily flooded wetlands which are fertile. Larger semipermanently and permanently flooded wetlands are used in spring, primarily as roosting sites. During fall migration swans utilize the larger permanently flooded wetlands and open riverine habitats.

\section{Canada Goose (Branta canadensis)}

Status: Regular migrant and nesting species, casual winter resident.

Migration: Common to locally abundant migrant throughout the region, especially numerous along the St. Croix River and in central St. Croix, Washington, and southern Burnett counties. Arrival of the first spring migrants in the Western Upland occurs 20-25 February and they have reached the Northern Highland (Burnett County) by 10 March. Peak spring migration occurs 25 March to 20 April. Largest numbers of migrants usually occur at the Crex Meadows Wildife Area, Burnett County. 
Fall migration begins about 1 September with the formation of loose flocks among local breeding birds. A gradual influx of migrants adds to the population, and peak fall migration occurs 15 October to 5 November. The largest concentration on record is 8,000 at Crex Meadows on 31 October 1970. The fall population rapidly declines after the peak and most birds have departed by 10 December.

Nesting Season Distribution: Currently a fairly common nesting species throughout the region, common at Crex Meadows. The success of the Canada goose as a nesting bird is related to the reestablishment of breeding adult giant Canada geese (B. c. maxima) at Afton, Washington County, and at Crex Meadows. A captive flock was established at Crex Meadows in 1957, and the first young were produced in the wild in 1960. This flock steadily increased and now over 100 pairs produce 300 young annually (WDNR files).

The Afton flock was established in 1960 and resulted in movement of breeding birds into nearby wetlands of Washington, Polk, and St. Croix counties. Canada geese were first recorded summering in St. Croix county in 1961 and nesting was recorded in 1963. Establishment of free-flying flocks of Canada geese was very popular in east central Minnesota and western Wisconsin throughout the 1960's and early 1970's. Many of these releases were successful and now several hundred breeding pairs return to the Valley each spring.

Winter: Casual winter resident in the Western Upland, primarily associated with the St. Croix River. Nearby agricultural fields are typically used for feeding during winter.

Habitat: Canada geese are usually found nesting on semipermanently and permanently flooded wetlands in the Western Upland. Many goose nests are found on old muskrat houses in these wetlands. At Crex Meadows, nesting Canada geese typically use large man-made impoundments.

\section{Brant (Branta bernicla)}

Status: Accidental, three fall records.

Records: A flock of three birds clearly identifiable to this species was observed at Crex Meadows, Burnett County, on 2 October 1954 (N. R. Stone). A group of 10 brant was observed at Crex Meadows on 6 October 1974 (K. H. Dueholm). N. R. Stone observed a brant referable to the Pacific subspecies (B. bernicla nigricans) on 31 October 1959 at Crex Meadows. The bird was observed from $120 \mathrm{~m}$; the neck markings were present and the black underwing coverts were noted, distinguishing this bird from the eastern race.

\section{White-fronted Goose (Anser albifrons)}

Status: Regular migrant.

Migration: Rare spring migrant, with records from Burnett, St. Croix, and Washington counties. Arrival dates do not demonstrate any pattern, rang- 
ing from 3 April 1968 and 8 April 1971 in Burnett County and 26 March 1976 in St. Croix County, to 12 April 1971 in Washington County. Most records occur during 5-20 May; the latest record was 2 June 1961 at Crex Meadows, Burnett County.

Rare fall migrant with records only from Burnett and St. Croix counties. Fall dates range from 16 September to 10 November 1964 (Crex Meadows). Most records are from 5-20 October. White-fronted geese are usually observed in fall in flocks of three to six. The largest flock recorded (12) was observed in St. Croix County on 28 March 1978.

Habitat: Spring migrants are usually observed on temporarily or semipermanently flooded wetlands. During fall migration most observations consist of birds in feeding flocks with other geese in corn or oat stubble fields.

\section{Snow Goose (Chen caerulescens)}

Status: Regular migrant, accidental in summer and winter.

Migration: Rare spring and fairly common fall migrant throughout the Valley; locally common at Crex Meadows, Burnett County, during fall migration. Spring migration begins with the arrival of small scattered flocks 5-15 April (earliest-16 March 1966, Washington County). No large populations occur during spring migration and most birds depart by 15 May (latest-3 June 1977, St. Croix County). Fall migrants arrive about 20 September (earliest-13 September 1974, Burnett County). Peak fall populations usually consist of groups totaling 200 to 300 individuals per county. Occasionally, exceptionally large concentrations occur at Crex Meadows Wildlife Area, including 11,650 on 2 November 1971 (WDNR files). Normal peak fall populations occur 15 October to 1 November and departure by 20 November.

Summer: N. R. Stone recorded a blue phase snow goose in molt in Black Brook Township, Polk County, on 20 June 1951. Another blue phase goose was recorded at Crex Meadows, Burnett County, on 7 July 1953.

Winter: P. D. Tweet observed a flock of six in Troy Township, St. Croix County, on 1 January 1977. These birds were probably late migrants.

Habitat: Primary habitat use of migrant snow geese consists of temporarily or semipermanently flooded wetlands. Adjacent agricultural fields, both row crops and hay, are heavily used for feeding.

\section{Mallard (Anas platyrhynchos)}

Status: Regular migrant, nesting species, and winter resident.

Migration: Common to locally abundant spring migrant in the Western Upland and Central Plain, fairly common to locally abundant in the Northern Highland. Determination of spring arrival dates is compounded by the presence of wintering birds. Movements of birds into the region are observed in late February with increases along the St. Croix River. Birds gradually move north arriving in the Northern Highland about 15 March. Peak spring 
populations occur 5-15 April; 6,000 to 8,000 birds are commonly observed in St. Croix County. Movement of nonbreeding mallards is rapid after peak periods; departure is by 1 May.

Fall migration begins 1-10 September with formation of local feeding flocks of adults and juveniles. Movements of migrants into the region begins about 20 September; peak populations occur 20 October to 1 November. Concentrations at Crex Meadows, Burnett County, have surpassed 11,000 twice $(11,500$ on 30 October 1967 and 15,000 on 3 November 1964). Recently, use of two refuges in St. Croix County has resulted in large numbers of mallards exceeding 10,000 (largest, 13,500 on 20 October 1977). Movement from the region is dependent on weather conditions. Departure of the largest number of birds occurs by 20 November and those not wintering have departed by 15 December.

Nesting Season Distribution: Common breeding duck throughout the region; nesting has been reported from all counties. Most research has centered on breeding populations in the pothole region of St. Croix and southern Polk counties, and at Crex Meadows. In the former area, Peterson (1978) estimated a breeding population of mallards of nearly 1.4 pairs per $\mathrm{km}^{2}$. At Crex Meadows, the estimated number of mallard breeding pairs on waterfowl survey transects ranged from 7 in 1973 to 55 in 1977 (WDNR files).

Winter: Common wintering duck wherever open water is available. Large early winter flocks are usually associated with open water areas along the St. Croix River. Cooper and Johnson (1977) reported that 75 to 200 mallards wintered near Afton, Washington County, from 1974 to 1977. Substantial wintering populations are also known to occur along the Kinnickinnic River in Pierce County and southern St. Croix County.

Habitat: Nesting mallards occupy a variety of wetland classes ranging from sedge meadows and acidic bogs to permanently flooded wetlands. Nesting pairs also use lowland forest habitat along rivers and streams, man-made impoundments, and stock-watering ponds created by the Soil Conservation Service. With the almost complete destruction of native grassland habitat, these ducks now commonly nest in haylands and oat and corn fields. Several thousand acres of Managed Grasslands have been established by government agencies to provide dense waterfowl nesting cover.

\section{Black Duck (Anas rubripes)}

Status: Regular migrant, nesting species, and winter resident.

Migration: Uncommon spring migrant in all regions; fairly common in the fall in the Northern Highland and locally at the Crex Meadows Wildlife Area, Burnett County. Spring migrants arrive along the St. Croix River about 15 March, generally moving to natural basin wetlands 1-10 April. No peak spring concentrations of black ducks have been noted, although they are most frequently observed 10-25 April. Departure from nonbreeding areas usually occurs by 15 May. Stragglers have been noted during late May and throughout the summer, primarily in the Western Upland.

Fall migrants arrive in the Western Upland 5-10 September. Peak fall 
populations occur 20 October to 10 November. Largest concentrations have been noted at the Crex Meadows Wildlife Area, Burnett County; 1,000 individuals were recorded 14 November 1964, 7 November 1965, and 28 October 1966. In the Western Upland, greatest numbers occur in central St. Croix County and along the St. Croix River and backwaters 25 October to 5 November. During fall migration, black ducks are usually observed in close association with flocks of mallards. Departure during fall occurs 15 November to 1 December, depending on weather conditions.

Nesting Season Distribution: Locally occurring nesting duck, primarily in the Northern Highland. Green and Janssen (1975) have mapped the breeding distribution of this duck in Minnesota and indicated it as a regular nesting bird in northern Pine County. There are two Washington County nest records: 24 May 1971, a female with 10 young was observed near Hugo, Minnesota, and nesting was reported during the summer of 1978 (Green 1979). Pair counts at Crex Meadows from 1957 to 1976 revealed an average of 1.1 pairs per year; broods were observed in 1957 and 1971 (WDNR files). Jackson (1941) observed one black duck near Solon Springs, Douglas County, on 8 August 1919. In St. Croix County, one pair was observed near New Richmond on 28 June 1975. They may have been nonbreeding birds or late migrants.

Winter: Fairly common winter resident wherever there is open water. Recorded primarily along the lower St. Croix River (Hudson-Stillwater) and below the dam at Taylors Falls. One midwinter record for Crex Meadows, Burnett County, 12 January 1955.

Habitat: The black duck is primarily a species of northern forested wetlands. Typical habitat consists of 0.5 ha or larger permanently flooded wetlands that are slightly acidic. Pairs and broods have also been noted on acid bog wetlands and beaver ponds.

\section{Gadwall (Anas strepera)}

Status: Regular migrant and nesting species, casual winter resident.

Migration: Uncommon migrant in the Western Upland and Central Plain; uncommon to rare in the Northern Highland except at Crex Meadows. Spring migrants arrive 25 March to 5 April in the Western Upland, reaching the Northern Highland 10-15 April tearliest-31 March 1958, Burnett County). Peak spring migration occurs 15-25 April and departure of nonbreeders occurs 5-15 May.

Fall migrants arrive 20-30 September reaching peak numbers 10-15 October. The largest concentration recorded at Crex Meadows, Burnett County, was 400 on 3 October 1970, and the largest number on the St. Croix County wetlands was 150 on 10 October 1975. Departure of fall migrants occurs after mid-October and most birds have left by 10 November.

Nesting Season Distribution: Rare and local nesting species with confirmed brood records from St. Croix, Polk, and Burnett counties. Gadwalls were released at the Crex Meadows Wildlife Area, Burnett County, during 1970 in an attempt to establish this prairie duck on seeded native prairie grasslands. 
This release met with limited success because the first brood was not observed until 1974. In the prairie wetlands of southern Polk and central St. Croix counties, gadwalls occur as a rare nesting species in a narrow band between Roberts (St. Croix County) and Alden Township (Polk County).

Winter: One bird was recorded on the Afton CBC in St. Croix County on 1 January 1973.

Habitat: Nesting gadwalls at Crex Meadows are generally associated with man-made potholes constructed to resemble natural basin wetlands. In St. Croix and southern Polk counties, breeding pairs are typically associated with seasonally and semipermanently flooded wetlands. Vegetation of these wetlands is composed of cattail, bulrushes, and various other emergent species.

\section{Pintail (Anas acuta)}

Status: Regular migrant and nesting species, one winter record.

Migration: Fairly common spring migrant in the Western Upland and Central Plain, uncommon and local in the Northern Highland. Pintails are among the first dabbling ducks to arrive in the region, usually 5-15 March. Peak spring populations occur 10-20 April, and depart by 15 May. Goddard (1975) found that pintails made up $0.9 \%$ of the spring migrant waterfowl in St. Croix County and $2.8 \%$ of the migrant dabbling duck population.

Fall migrants arrive in late August. During the fall, pintails are fairly common at Crex Meadows, Burnett County, in central St. Croix, and eastern Washington counties, and in southern Polk County. They are rare and local in other regions during this period. Peak fall populations occur 25 September to 10 October and departure occurs by 15 November. Largest fall populations at Crex Meadows have been 400 birds reported on 4 October 1956 , 29 September 1964, and 27 September 1973.

Nesting Season Distribution: Uncommon and local nesting species with records from Washington (Green and Janssen 1975), St. Croix, Polk, and Burnett counties. In central St. Croix and southern Polk counties, pintails made up $0.8 \%$ of the breeding duck population (Peterson 1978). At Crex Meadows, waterfowl pair counts indicated that pintails constituted about $1 \%$ of the yearly breeding population from 1957-78 (WDNR files).

Winter: One pintail was observed on the St. Croix River, Burnett County, on 12 and 13 January 1949 (Robbins 1949). Afton CBC data include single pintails on 1 January 1972 and 1973, and two birds on 1 January 1974, 1976 , and 1978.

Habitat: Nesting pintails are typically associated with seasonally and semipermanently flooded wetlands that support a lush growth of emergent aquatic vegetation.

\section{Green-winged Teal (Anas crecca)}

Status: Regular migrant and nesting species, two winter records. 
Migration: Fairly common migrant in all regions, locally common during spring in the Western Upland. Spring migrants begin to arrive in the Western Upland 25 March to 1 April (earliest-15 March, St. Croix County). Arrival in the Northern Highland occurs 5-10 April. Peak spring populations occur 15-25 April and departure of nonbreeding birds occurs by 15 May. In St. Croix County, Goddard (1975) found that green-winged teal made up $4.6 \%$ of the spring waterfowl population and $13.6 \%$ of the dabbling ducks.

Fall migration begins about 25 August with a slow increase of numbers in the Central Plain and Northern Highland. Peak populations occur 1-15 October in the Northern Highland. The largest population recorded at Crex Meadows, Burnett County, was 600 birds on 2 October 1971. Peak fall populations in the Western Upland occur 10-25 October. Although departure is fairly slow, most green-winged teal have departed by 15 November.

Nesting Season Distribution: Uncommon to rare nesting species throughout the Valley. Most observations of birds during this period are made in the prairie wetland region of St. Croix, Polk, and Washington counties, and at Crex Meadows. Green-winged teal are the fourth most common breeding duck at Crex Meadows (WDNR files). In St. Croix and Polk counties, greenwinged teal constitute about $0.4 \%$ of the breeding waterfowl population.

Winter: One bird was observed on the Afton CBC on 1 January 1972. N. R. Stone observed three birds at Clam Lake, Burnett County, on 13 February 1950 (Robbins 1950a).

Habitat: Pairs and broods are associated with seasonally and semipermanently flooded wetlands. Of seven green-winged teal nests that I located in St. Croix County in 1976, all were in alfalfa fields.

\section{Blue-winged Teal (Anas discors)}

Status: Regular migrant and nesting species.

Migration: Abundant migrant in the Western Upland, common in the Central Plain, and fairly common (locally common) in the Northern Highland. Goddard (1975) found that blue-winged teal made up $14.4 \%$ of all waterfowl and $43 \%$ of all dabbling ducks using St. Croix County wetlands in spring.

Blue-winged teal are among the last migrant ducks to arrive in spring; average arrival date is 5 April (earliest-23 March 1976, St. Croix County). Populations build rapidly and peak numbers are usually noted 20 April to 10 May. The first migrants usually arrive in the Northern Highlands about 20 April and reach peak populations 5-15 May.

Fall migrants begin to form large feeding aggregations in late July and early August. Peak fall populations occur early; the largest number $(1,200)$ observed at Crex Meadows, Burnett County, was on 17 September 1976. Typically, large numbers of blue-winged teal are observed 10-25 September in St. Croix and Washington counties (1,000 on 23 September 1975). Departure from the region is very rapid after peak populations occur, and most 
birds are gone by 20 October (latest-2 December 1973, Washington County).

Nesting Season Distribution: Abundant nesting duck on prairie wetlands of St. Croix, Polk, and Washington counties. Preliminary data collected by the WDNR (Peterson 1978) show a breeding density of about 1.7 pairs per $\mathrm{km}^{2}$ in St. Croix and Polk counties. At Crex Meadows, blue-winged teal are the most abundant breeding duck, averaging nearly $42 \%$ of all breeding pairs observed from 1957-78 (WDNR files).

Habitat: Blue-winged teal use a wide variety of wetland types for nesting, ranging from sedge meadows to bog wetlands. Largest densities occur on seasonally, semipermanently, and permanently flooded wetlands containing an abundance of submerged and emergent aquatic vegetation. To a lesser extent, breeding pairs also use stock ponds and dugout ponds created by the Soil Conservation Service. Lowland Deciduous Forest habitat along streams and rivers is regularly used.

\section{Cinnamon Teal (Anas cyanoptera)}

Status: Casual spring and fall migrant.

Records: Cinnamon teal have been observed four times at Crex Meadows, Burnett County: 14 April 1953 (six birds); 25 April 1955 (two); 8 May 1956. Hunt and Jahn (1968) observed a male cinnamon teal at Crex Meadows on 21 April 1968. One bird was observed in Washington County on 16 April 1963 (Honetschlager 1963). Roberts (1932) cited the collection of a male cinnamon teal near Stacy, Chisago County, "sometime between October 515, 1923." A second male was obtained "at almost identically the same place" on 15 September 1924.

\section{American Wigeon (Anas americana)}

Status: Regular migrant and casual nesting species.

Migration: Fairly common migrant in the Western Upland; uncommon in the Central Plain and Northern Highland. Goddard (1975) found that American wigeon made up $2.2 \%$ of all waterfowl and $4.5 \%$ of the dabbling ducks using St. Croix County wetlands during spring migration.

Spring $r$ ligrants arrive in the Western Upland 20-30 March; the earliest birds occur along the St. Croix River. Arrival is somewhat later at Crex Meadows, Burnett County, where the average arrival is 8 April. Movement into the Valley is very rapid and peak populations are usually observed 10-25 April. Departure from the Valley usually occurs 10-25 May.

Fall migrants arrive in late August and build up rapidly, reaching peak populations 25 September to 10 October. The largest number observed at Crex Meadows (400) occurred on 3 October 1970. In St. Croix County, fall peak populations of 200 to 300 birds are common and 720 were observed on 3 October 1976. Departure from the Valley occurs 1-10 November (latest15 December 1974, Washington County). 
Nesting Season Distribution: Nest records of American wigeon have been confirmed only at Crex Meadows: two broods (eight each) in July 1967 (first brood observed on 14 July); one brood observed in 1970 and 1971; one brood of four observed on 21 July 1975, and two broods during 1976. Elsewhere, summering pairs are regularly observed in St. Croix and Polk counties. The only evidence suggestive of nesting was a female acting "broody" on a pond $1.6 \mathrm{~km}$ northwest of New Richmond on 20 July 1977. Although summering pairs are regularly observed in Washington County near Lake Elmo, no evidence of nesting has been obtained.

Habitat: Breeding pairs at Crex Meadows are typically associated with large man-made impoundments. In St. Croix and Washington counties summering American wigeon pairs are associated with semipermanently flooded wetlands.

\section{Northern Shoveler (Anas clypeata)}

Status: Regular migrant and nesting species.

Migration: Fairly common spring migrant in the Western Upland, uncommon to rare elsewhere. Rare throughout the Valley during fall migration. Goddard (1975) found that the northern shoveler made up $2.2 \%$ of the waterfowl population and $6.4 \%$ of the dabbling duck population in St. Croix County during spring migration.

Spring migrants arrive 1-5 April (earliest-24 March 1976, St. Croix County). Peak spring migration in the Western Upland occurs 20 April to 5 May and departure occurs 15-20 May. Elsewhere, arrival occurs 10-20 April (average 15 April at Crex Meadows). Peak spring populations occur about 10 May and departure by 20 May. Fall migrants begin to arrive 10-20 August. Peak fall populations cannot be determined because of the small number of birds usually observed. Departure from the Valley occurs by 15 November.

Nesting Season Distribution: Regular nesting species at Crex Meadows, Burnett County, where up to eight pairs per year have been recorded on breeding waterfowl survey transects (WDNR files). Elsewhere, northern shovelers are encountered irregularly during the breeding season in St. Croix, southern Polk, and Washington counties.

Habitat: Soft-bottomed semipermanently and permanently flooded wetlands supporting populations of macroinvertebrates are usually occupied during the nesting season. During spring migration, extensive use is made of temporarily flooded wetlands.

\section{Wood Duck (Aix sponsa)}

Status: Regular migrant and nesting species, casual in early winter.

Migration: Common migrant throughout the Valley. Spring migrants arrive in the Western Upland 15-20 March (earliest-6 March 1975, Pierce County). Spring migration progresses according to the opening of river sys- 
tems and arrival in the Northern Highland occurs 1-10 April. Peak spring migration occurs 15-25 April in the Western Upland and 25 April to 5 May in the Northern Highland. Goddard (1975) reported that wood ducks constituted $0.4 \%$ of the total spring waterfowl population and $1.2 \%$ of the dabbling duck population on prairie wetlands in St. Croix County. This low percentage is undoubtedly related to their preference for riverine habitats.

Fall migration begins during mid-August with the formation of feeding groups. A gradual buildup in numbers occurs throughout September. Peak populations at Crex Meadows, Burnett County, usually occur 20 September to 5 October; the largest groups were noted on 4 October $1967(1,500)$ and 14 September $1968(1,000)$. Elsewhere, peak populations occur 1-20 October. Especially important riverine staging areas occur along the Kettle River (Pine County), Apple River (Polk and St. Croix counties), and Willow River (St. Croix County). Departure from the Valley occurs rapidly after mid-October; the latest dates were 20 November 1976 and 20 December 1956 (both Washington County).

Nesting Season Distribution: Uncommon to fairly common nesting species in all regions. Nesting records exist for all counties and nesting birds are numerous along the larger tributaries of the St. Croix River. In St. Croix County, the wood duck ranks third in abundance behind mallard and bluewinged teal as a breeding duck (B. A. Moss, personal communication).

Winter: Winter records include 1 January 1972 and 1973 (Afton CBC, Washington County); 27 December 1970 (Solon Springs CBC, Douglas County); and 20 January 1975 (McKenzie Creek, Polk County).

Habitat: Primary habitat use by nesting wood ducks includes wooded streams, rivers, backwater sloughs, and wooded lakes. In the Northern Highland, breeding pairs also use tamarack bogs and spruce-lined lakes. In the Western Upland, use of prairie wetlands has been enhanced by the placement of artificial nest boxes.

\section{Redhead (Aythya americana)}

Status: Regular migrant and casual nesting species.

Migration: Fairly common migrant in the Western Upland, particularly in western St. Croix and eastern Washington counties. Uncommon to rare elsewhere, especially in the Northern Highland. Spring migrants arrive in the Western Upland 5-10 April (earliest-23 March, St. Croix County). Peak abundance occurs 25 April to 5 May and most have departed by 25 May. Goddard (1975) found that redheads made up $2 \%$ of the total spring waterfowl population and $4.5 \%$ of the spring diving duck population in St. Croix County. At the Crex Meadows Wildlife Area, Burnett County, the average date of spring arrival is 15 April; peak populations occur 1-10 May, and departure by 1 June.

Fall migrants begin to arrive 10-20 September. Populations build slowly through October, reaching largest numbers 20 October to 1 November. The principal fall migration route used by redheads is south of the Valley. Because of this, concentrations larger than 50 birds are rarely encountered 
during fall migration. Departure from the region occurs rapidly after 15 November; occasional stragglers linger along open areas of the St. Croix River until 1 December.

Nesting Season Distribution: There are six breeding records for the Valley: a female with a brood of four on West Twin Lake, St. Croix County, 1968 (J. T. Lokemoen); a female with a brood of four on East Twin Lake, St. Croix County, 1975 (B. A. Moss); females with broods of five and six on the Gust Waterfowl Production Area, St. Croix County, 1976 and 1977 (C. A. Faanes); two broods of six and seven on Oakridge Lake during July 1976. Elsewhere, occasional summering pairs have been observed in central Washington and southern Polk counties, although no broods have been observed. At Crex Meadows, summering pairs are noted almost yearly, although the only suggestion of nesting was a female acting "broody" on 16 June 1975 (S. D. Robbins, personal communication).

Habitat: All redhead broods have been observed on large permanently flooded wetlands where the dominant emergent vegetation consists of cattail and river bulrush.

\section{Ring-necked Duck (Aythya collaris)}

Status: Regular migrant and nesting species, casual in winter.

Migration: Abundant migrant throughout the Valley. Spring migrants arrive in the Western Upland about 15 March and the Northern Highland 1-5 April (earliest-20 March 1950, Burnett County). Peak populations of spring migrants occur 20 April to 1 May. Goddard (1975) found that ringnecked ducks were the second most abundant spring migrant duck in St. Croix County, making up $14.8 \%$ of the total waterfowl population and $32.8 \%$ of the diving duck population. Departure from nonbreeding areas occurs by 20 May.

Fall migrants begin to form flocks in the Northern Highland in mid-September and the first migrants reach the Western Upland about 25 September. Peak fall populations at Crex Meadows, Burnett County, usually occur 20-30 October and have included 5,000 (25 October 1967), 5,500 (25 October 1965), and 7,500 (26 October 1966). In the Western Upland, peak populations occur about 1 November and include up to 1,500 birds (B. A. Moss, personal communication). Departure from the Valley occurs steadily through November with stragglers occurring along the St. Croix River until 1 December.

Nesting Season Distribution: Uncommon nesting species in the Western Upland; fairly common in the Central Plain and Northern Highland, common at Crex Meadows. Breeding records have been obtained in all counties except Pierce and the breeding range includes the area north of Marine-onSt. Croix and New Richmond.

Breeding waterfowl surveys at Crex Meadows reveal that the ring-necked duck is the third most numerous nesting species (WDNR files). In St. Croix and southern Polk counties, Peterson (1978) found that ring-necked ducks constituted an insignificant percentage of the breeding population. How- 
ever, most ring-necked duck breeding activity in St. Croix and Polk counties occurs west and north of Peterson's study area.

Winter: One male was observed on the Afton CBC 1 January 1975.

Habitat: Ring-necked ducks are primarily a species of permanently flooded wetlands in the forested areas of the Valley. Typical brood habitat consists of slightly acidic water and scattered growths of pond lily, bulrush, and cattail. Beaver ponds are commonly used in the northern counties and acid bogs are occasionally used.

\section{Canvasback (Aythya valisineria)}

Status: Regular migrant and casual summer resident, one nesting record and one winter record.

Migration: Uncommon spring and fall migrant in the Western Upland and Central Plain, rare in the Northern Highland. Spring migrants arrive in late March (earliest-16 March). Peak abundance occurs 10-25 April and departure occurs 10-20 May .Goddard (1975) found that the canvasback made up $0.4 \%$ of the total spring waterfowl population and $1.0 \%$ of the diving duck population in St. Croix County. Fall migration begins in mid-September with arrival of small flocks on the larger lakes and the St. Croix River. Peak fall populations occur 15 October to 1 November and departure by 30 November.

Nesting Season Distribution: Casual summer resident in St. Croix County and at Crex Meadows, Burnett County. The only nesting record is my observation of a hen with a brood of eight on Oakridge Lake, St. Croix County, on 8 July 1976. Summering pairs are occasionally observed on other prairie wetlands although no evidence of nesting is available. Elsewhere, summering pairs were observed at Crex Meadows in 1950, 1962, 1975, and 1978.

Winter: A male canvasback was observed on the Afton $\mathrm{CBC}$, Washington County, on 1 January 1975.

Habitat: The nesting record was obtained on a large permanently flooded wetland. Dominant vegetation included softstem bulrush, cattail, and river bulrush. Most additional summer records are the birds on semi-open permanent wetlands. During migration, canvasbacks utilize most wetland types, although a preference is shown for semipermanently and permanently flooded wetlands.

\section{Greater Scaup (Aythya marila)}

Status: Regular migrant.

Migration: Rare migrant throughout the Valley. Spring migrants arrive 5-15 April and are most regularly observed 25 April to 5 May. First migrants are usually observed on the St. Croix River, followed by an increase of observations away from the river. Departure from the Valley occurs by 15 May (latest-29 May 1968, Burnett County). Goddard (1975) failed to record the greater scaup during four spring field seasons in St. 


\section{Croix County.}

Fall migrants occur 5 October to 20 November; most records are 20 October to 5 November. Fall migrants are usually observed intermixed with large rafts of lesser scaup, whereas in spring migration, greater scaup seem to be more segregated from lesser scaup.

Habitat: Large, open permanently flooded wetlands typically support the most greater scaup in this region. Cedar Lake on the Polk-St. Croix County line is probably the most productive lake in the region for observing greater scaup.

\section{Lesser Scaup (Aythya affinis)}

Status: Regular migrant, casual nesting species, and occasional in early winter.

Migration: Abundant migrant throughout the Valley. The lesser scaup is the most numerous migrant duck in the Valley. In St. Croix County, Goddard (1975) found that lesser scaup made up $24.6 \%$ of the total spring waterfowl population and $54.6 \%$ of the diving duck population. Spring migrants arrive in the Western Upland 10-15 March (earliest-6 March 1976, Washington County) and the Northern Highland 1-10 April. Peak spring populations occur 20 April to 10 May when flocks of 700 to 1,000 individuals are typically observed on larger lakes. Departure occurs 20-30 May.

Fall migrants arrive 20 September to 1 October. Fall migration is characterized by a rather low increase in numbers until about 20 October when large influxes occur. Peak fall populations at Crex Meadows Wildlife Area, Burnett County, occur 25 October to 5 November and have totaled up to 7,000 individuals (30 October 1965). In the Western Upland, peak fall populations larger than 3,000 individuals are observed 25 October to 5 November. Departure from the Valley is dependent on ice conditions on larger lakes; most birds depart by 1 December.

Nesting Season Distribution: Regular summer resident on wetlands in Polk, St. Croix, and central Washington counties. Usually up to 10 pairs can be found on wetlands near New Richmond, St. Croix County. There are two brood records for the Valley; both broods were found on 7 July 1976, on wetlands in Alden Township, Polk County. These broods were within $0.8 \mathrm{~km}$ of each other and constituted the eighth and ninth, 20th century breeding records for Wisconsin. At Crex Meadows, 10 pairs were observed during 1958. Since then at least one pair has been present yearly; however, no broods have been observed. Jackson (1942) reported the collection of a male lesser scaup on Upper St. Croix Lake, Douglas County, on 1 August 1919.

Winter: Occasional early winter visitor primarily on open stretches of rivers. These birds are probably late fall migrants rather than wintering birds because no midwinter records exist. Dates range from 22 December 1956 to 1 January 1973, 1975, 1976 (Afton CBC); 29 December 1973 to 3 January 1976 (Suburban St. Paul CBC); 12-13 January 1949, 12 January 1955, 9 January 1956, and 7 January 1957 (Crex Meadows); 31 January 1949, St. Croix Falls (Polk County); and 23 December 1975, Solon Springs CBC 
(Douglas County).

Habitat: The Polk County broods were observed on semipermanently flooded wetlands. Dominant vegetation included cattail, burreed, and coontail. Most summering pairs are observed on small semipermanent wetlands.

\section{Common Goldeneye (Bucephala clangula)}

Status: Regular migrant and winter resident, one summer record.

Migration: Common migrant throughout the Valley, most numerous along the St. Croix River and on large lakes of the Northern Highland. Fall migrants arrive in the Northern Highland 20 September to 1 October and reach the Western Upland 10-20 October. Peak fall common goldeneye populations occur 10-30 November.

Spring migrants reach peak abundance 10 March to $1 \mathrm{April}$ and most have departed by 1 May (latest-30 May 1967, Burnett County). Movement of spring migrants is similar to fall; most birds use rivers and large lakes. Goddard (1975) found that common goldeneyes on prairie wetlands made up $<1 \%$ of the total spring waterfowl population; his 4-year observations totaled 707 individuals. On the St. Croix River $<16 \mathrm{~km}$ from Goddard's study area, daily totals in excess of 100 individuals were recorded on 8 March 1975, 11 March 1977, and 9 April 1978. Yearly totals in excess of 2,000 individuals along the $\mathrm{St}$. Croix River were regularly recorded from 1972 to 1978 .

Winter: Common winter resident wherever open water is present. Primary wintering populations occur at the confluence of the St. Croix and Mississippi Rivers at Prescott, Wisconsin (150 to 200 individuals); below the Alan S. King generating plant at Bayport (Washington County); near Hudson (425 on 1974 Afton CBC and 360 on 1975 Afton CBC); and below the electric generating dam at St. Croix Falls-Taylors Falls (50 to 100 individuals).

Summer: S. D. Robbins observed a lone male throughout the summer of 1967 in St. Croix County.

Habitat: Large open stretches of rivers that apparently support healthy populations of fishes and invertebrates. During migration, common goldeneyes are typically associated with large ( $>20$ ha) permanent lakes.

\section{Barrow's Goldeneye (Bucephala islandica)}

Status: Accidental, two records.

Records: Faanes and Goddard (1976) cited one observation from East Twin Lake, St. Croix County, on 8 May 1975. M. R. Olson observed one male along Trout Brook Road near Hudson, St. Croix County, on 1 January 1977. The bird was observed again on 2 January 1977 on the St. Croix River.

\section{Bufflehead (Bucephala albeola)}

Status: Regular migrant, one summer and one winter record. 
Migration: Fairly common migrant in the Western Upland and Central Plain; common on forested lakes in the Northern Highland. Goddard (1975) found that buffleheads constituted $1.6 \%$ of the total spring waterfowl population and $3.5 \%$ of the diving duck population on prairie wetlands in central St. Croix County.

Spring migrants arrive in the Western Upland 20 March to 1 April (earliest-13 March 1966, Washington County) and peak populations occur about 20 April. Migrants arrive in the Northern Highland 1-10 April, reaching peak numbers 15-25 April. Departure from the Valley occurs by 25 May. Fall migrants arrive in the Northern Highland about 1 October and the Western Upland about 5 October. Peak fall populations occur 20 October to 1 November and departure occurs by 25 November. Peak fall populations on central St. Croix County wetlands usually total 150 to 200 individuals.

Summer: S. D. Robbins observed a lone bufflehead at Crex Meadows, Burnett County, on 17 June 1976. This may have been an injured bird.

Winter: A flock of 40 buffleheads was observed on the St. Croix River near Grantsburg, Burnett County, from 12-13 January 1949 (Robbins 1949).

Habitat: Buffleheads are associated with a variety of wetland types during spring migration, including temporarily, seasonally, and permanently flooded wetlands, and riverine habitats. During fall migration buffleheads are usually associated with large semipermanently and permanently flooded wetlands.

\section{Oldsquaw (Clangula hyemalis)}

Status: Casual, five records.

Records: Oldsquaw were observed on Oakridge Lake near New Richmond, St. Croix County, on 24 October 1974 (S. R. Schneider); 14 October 1975 (R. E. Faanes); and 2 October 1977 (C. A. Faanes). One was observed at Crex Meadows Wildlife Area, Burnett County, on 22 April 1952 (Strelitzer 1952). In Washington County, three birds were observed on 6 January 1965.

\section{Common Eider (Somateria mollissima)}

Status: Accidental, one record.

Record: One female common eider was shot on Phantom Lake, Crex Meadows Wildlife Area, Burnett County, on 10 November 1968 (Tessen $1969 b)$.

\section{White-winged Scoter (Melanitta deglandi)}

Status: Casual, four records.

Records: N. R. Stone observed one at Crex Meadows, Burnett County, on 8 May 1950 (Robbins 1950b), and R. Brown observed one there on $12 \mathrm{Au}$ gust 1975. C. A. Faanes and W. Norling observed a female on Oakridge 
Lake, St. Croix County, on 18 October 1974. I observed a female at Amery, Polk County, on 9 November 1976.

\section{Surf Scoter (Melanitta perspicillata)}

Status: Casual, three records.

Records: A single surf scoter was observed at Crex Meadows Wildlife Area, Burnett County, on 5 October 1974. On 6 October 1974, two birds were shot from a group of four at Crex Meadows by J. O. Evrard. Photos were taken of the two birds. B. A. Moss observed a flock of six surf scoters on Deer Lake, Polk County, on 30 October 1975.

\section{Black Scoter (Melanitta nigra)}

Status: Casual, two records.

Records: A female black scoter was observed on West Twin Lake near Roberts, St. Croix County, on 18 October 1974 (Faanes and Goddard 1976). On 1 January 1977, I observed a female black scoter with a group of black ducks and mallards at the mouth of the Kinnickinnic River, Pierce County (Lien and Lien 1977).

\section{Ruddy Duck (Oxyura jamaicensis)}

Status: Regular migrant and nesting species, accidental in winter.

Migration: Fairly common migrant in the Western Upland and Central Plain, rare and local in the Northern Highland. Goddard (1975) reported that ruddy ducks constituted $1 \%$ of the total spring waterfowl population and $2.2 \%$ of the diving duck population in St. Croix County. Ruddy ducks are the latest arriving waterfowl species in spring. The average arrival date is 10 April in St. Croix County and 25 April at Crex Meadows, Burnett County (earliest dates-24 March 1976, St. Croix County and 4 April 1948, Burnett County). Peak spring populations in St. Croix, Polk, and Washington counties occur 25 April to 10 May; departure of nonbreeding birds is by 20 May. Fall migration begins in early September and peak numbers occur 25 September to 15 October. The largest groups recorded during fall migration range from 25 to 30 birds per wetland. Departure from this region occurs by 1 November (latest-27 November 1967, Washington County).

Nesting Season Distribution: Uncommon and local breeding duck on prairie wetlands of St. Croix, Polk, and Washington counties. These breeding populations occur in pockets of high density wetlands in the respective counties. Peterson (1978) reported that ruddy ducks made up $<1 \%$ of the total breeding duck population in St. Croix and Polk counties. Three brood records have been obtained at Crex Meadows, two in 1973 and one in 1974.

Winter: One ruddy duck was observed on the Afton CBC on 22 December 1956. 
Habitat: Ruddy ducks are characteristic of semipermanently and permanently flooded wetlands that are dominated by cattail, hardstem bulrush, and river bulrush. Most wetlands occupied by breeding ruddy ducks vary from 1-3 m deep.

\section{Hooded Merganser (Lophodytes cucullatus)}

Status: Regular migrant and nesting species, two winter records.

Migration: Uncommon migrant throughout the Valley, fairly common locally along heavily wooded lakes and streams in the Northern Highland. Goddard (1972) reported that hooded mergansers made up $0.2 \%$ of the total spring waterfowl population in St. Croix County. This low percentage resulted from censusing prairie wetlands that are not utilized regularly by hooded mergansers. Spring migrants arrive in the Western Upland 1-10 April (earliest-23 March 1968, St. Croix County) and the Northern Highland about 10 April (earliest-14 March 1966, Burnett County). Peak abundance occurs 20 April to 5 May and departure from nonbreeding areas occurs by 15 May. Fall migration begins in early September in the Northern Highland and migrants reach the Western Upland about 15 September. Peak fall populations occur 15 October to 1 November and departure by 20 November. Peak fall populations in western Wisconsin range from 50 to 75 birds on important staging wetlands.

Nesting Season Distribution: Fairly common (and local) breeding duck throughout the Valley. Hooded mergansers make up a small proportion of the breeding population on prairie wetlands where the most intensive surveys have been conducted. Lack of survey work along streams and in wooded lake regions contributes to the poor understanding of their breeding distribution.

Winter: There are two winter records including one bird along the St. Croix River near Grantsburg, Burnett County, on 9 January 1956 and one bird on the Afton CBC on 1 January 1975.

Habitat: In the Western Upland and Central Plain, breeding hooded mergansers use heavily wooded river and stream habitats for breeding. An abundance of dead trees providing natural nesting cavities is an important component of their breeding habitat. In the Northern Highland, breeding birds occupy large forest-bordered lakes and acidic bog-type lakes in addition to riverine habitats.

\section{Common Merganser (Mergus merganser)}

Status: Regular migrant and winter resident, two summer records.

Migration: Common migrant throughout the Valley. Goddard (1975) reported that common mergansers made up $0.1 \%$ of the total spring waterfowl population in St. Croix County. This estimate reflects late dates of censusing, which did not coincide with the peak migration period of this bird, rather than an actual low population. Spring migration begins with a 
noticeable influx about 20 February. Spring populations build rapidly through March reaching peak numbers 20-30 March and most birds have departed by 30 April. Fall migrants arrive in the Northern Highland 20-30 September and reach the Western Upland about 10 October. Peak fall populations occur 10 November to 1 December and nonwintering birds have departed by 15 December. During peak fall periods, up to 1,000 individuals have been recorded along the lower St. Croix River in Washington County.

Winter: Uncommon winter resident of the lower St. Croix River and along open stretches of water on major tributaries. The largest group recorded on the Afton CBC was 65 birds on 1 January 1958. Winter populations are directly related to the severity of winter weather. During 1974-75, groups of 30 to 35 common mergansers were regularly observed along the St. Croix River through late December and early January. The record cold of 11 January $1975\left(-40^{\circ} \mathrm{C}\right)$, froze nearly the entire river system and common mergansers were not observed again until mid-February when the first migrants returned.

Summer: Three common mergansers were observed in Chisago County on 16 June 1975 (Eckert 1976), and a lone male was observed near New Richmond, St. Croix County, on 27 June 1975. These birds undoubtedly were lingering migrants.

Habitat: Primarily a species of large, deep, permanently flooded wetlands and the major rivers of the Valley.

\section{Red-breasted Merganser (Mergus serrator)}

Status: Regular migrant, two summer and one winter records.

Migration: Fairly common migrant throughout the Valley, occasionally common on larger lakes of the Central Plain. Goddard (1975) reported that red-breasted mergansers made up only $0.3 \%$ of the total spring waterfowl population in St. Croix County. This estimate indicates that censuses were concentrated on smaller wetlands and were not conducted to coincide with peak migration.

Spring migrants arrive in the Western Upland about 20 March and reach the Northern Highland 1-10 April. Peak spring migration occurs 10-25 April and departure by 15 May. Fall migrants arrive in the Northern Highland 20-30 September and reach the Western Upland about 10 October. Peak fall populations occur 25 October to 15 November and departure by 10 December. During the peak of fall migration, concentrations of 50 to 75 birds are typically recorded on important staging wetlands.

Summer: A lone female was observed at Crex Meadows, Burnett County, on 1 July 1955. In Washington County an injured bird was observed 24 June 1975 (Eckert 1976).

Winter: A group of four was observed on the St. Croix River on the Afton CBC, 1 January 1975. Five were observed in St. Croix County on 5 January 1942 (Barger 1942).

Habitat: Red-breasted mergansers are characteristic of large, deep-water 
permanently flooded wetlands and riverine habitats. Occasional small groups of migrants occur on semipermanently flooded wetlands during spring migration.

\section{FAMILY CATHARTIDAE: American Vultures}

\section{Turkey Vulture (Cathartes aura)}

Status: Regular migrant and probable nesting species.

Migration: Fairly common migrant throughout the Valley, becoming common at Crex Meadows during the fall. Spring migrants arrive during the first week of April (earliest-24 March 1963 and 1977, Pierce County). Peak spring migration occurs between 20 April and 1 May and most depart by 15 May. Peak fall migration occurs 15-25 September; departure occurs by 15 October (latest-23 November 1948 and 30 November 1950, Burnett County).

Nesting Season Distribution: Rare to uncommon summer resident throughout the Valley, most regularly observed in the forested regions along the upper St. Croix River. Roberts (1932) reported turkey vultures nesting "along the St. Croix River"; however, he provided no dates or locations. Turkey vultures are regularly observed during the summer between Prescott and Stillwater. This area of extensively wooded bluffs provides excellent breeding habitat for vultures. Although young are observed during late July, no nests have been found.

Habitat: Habitat used by turkey vulture during the nesting season consists of Southern Deciduous Forest occurring on bluffs along the St. Croix River.

\section{FAMILY ACCIPITRIDAE: Hawks and Harriers}

\section{Swallow-tailed Kite (Elanoides forficatus)}

Status: Accidental, one record.

Record: One bird was found dead along Highway 95 near Marine-on-St. Croix, Washington County, on 29 April 1966. The specimen is now in the collection of the Minnesota Museum of Natural History (\#23152).

Mississippi Kite (Ictinia mississippiensis)

Status: Accidental, one record.

Record: A single bird was observed at Crex Meadows, Burnett County, on 27 May 1976 (Hofslund and Niemi 1977). 


\section{Northern Goshawk (Accipiter gentilis)}

Status: Regular migrant and winter resident, casual nesting species.

Migration: Rare migrant throughout the Valley. Most regularly observed in the forested areas of the Northern Highland and Central Plain, casual in the Western Upland. Fall migrants begin to arrive in mid-September and are most conspicuous from mid-October to mid-December. Spring migration begins in late February with dispersal toward nesting areas. Goshawks are most conspicuous in spring 15 March to 10 April and have departed by 30 April.

Nesting Season Distribution: One nesting record for Burnett County; an adult incubating during May 1973 (W. Norling). A nest at Camp Wilder, Washington County, in 1967, was abandoned because of excessive human activity in the immediate area (Huber 1967). Numerous sight records, primarily from the Northern Highland, indicate that additional nesting records are probable.

Winter: Rare to uncommon winter resident throughout the Valley. Most frequently observed in the heavily forested Northern Highland.

Habitat: The Burnett County nest was in mixed jack pine-oak habitat. Additional nesting season records have been obtained from mature Northern Hardwood Forest, mixed coniferous forest, and jack pine-oak habitat.

\section{Sharp-shinned Hawk (Accipiter striatus)}

Status: Regular migrant, nesting species, and winter resident.

Migration: Uncommon spring and fairly common fall migrant throughout the Valley. Occasionally 30 to 40 migrant sharp-shinned hawks can be observed per day along the St. Croix River. Spring migration begins in midMarch; largest numbers occur 10-25 April. Most birds have arrived on nesting territories by 10 May. Fall migration begins in mid-August and peak numbers are reached 10 September to 10 October. Most have departed by 15 November.

Nesting Season Distribution: Uncommon to rare during the nesting season in the Central Plain and Northern Highland. Although this hawk is regularly observed during the nesting season, only one nest has been found. On 23 May 1976, I found one sharp-shinned hawk nest in the McKenzie Creek Wildlife Area, Polk County. Other observers, primarily Jackson (1941) and Bernard (1967) have recorded this species during the nesting season but failed to find a nest. In the Minnesota counties, Green and Janssen (1975) stated that during the summer this hawk is "most numerous in the north central, northeastern ... regions."

Winter: Uncommon to rare winter resident in the Western Upland and Central Plain. Casual in midwinter in the Northern Highland. Three were observed on Solon Springs (Douglas County) CBC on 30 December 1973.

Habitat: The Polk County nest was situated about $4.6 \mathrm{~m}$ from the ground in an aspen tree. Surrounding vegetation consisted of young as- 
pen-maple-basswood forest, intermixed with red pine. Additional summer observations have been made in similar habitat and in brushy "edge" situations. This hawk is usually observed in oak-maple woodlots along the St. Croix River during winter. Occasionally, an individual will frequent feeding stations in residential areas.

\section{Cooper's Hawk (Accipiter cooperii)}

Status: Regular migrant, nesting species, and winter resident. The WDNR has listed this species as threatened (Les 1979). Alteration of nesting habitat resulting from intensive farming is a primary cause for their decline.

Migration: Uncommon to rare migrant throughout the Valley. Spring migration begins in mid-March; birds are most frequently encountered 10-25 April. Nonsummering birds have departed by 15 May. Fall migration begins in late August and continues through mid-October. Because of the low number of birds observed during fall migration, no indication of peak movements is provided.

Nesting Season Distribution: Rare nesting species throughout the Valley. Although this hawk is regularly observed during the summer, only two confirmed nesting records exist. On 13 June 1976 a nest containing two young. and on 29 June 1976 a nest containing one young, were found $8 \mathrm{~km}$ west and $4.8 \mathrm{~km}$ east of Star Prairie, St. Croix County. Goddard (1972) reported one pair during the breeding season in Pierce County and Jackson (1941) reported a breeding season record (31 May 1919) for Burnett County. Numerous other breeding season records exist, but data on eggs or young are lacking.

Winter: Rare winter resident in the Western Upland; casual to absent elsewhere.

Habitat: Both St. Croix County nests were in second-growth red oak woodlots, bordered by brushy fencerows. I have observed this species during the breeding season in similar second-growth habitats and in mixed jack pine-oak situations in Burnett and Pine counties. Wintering birds are regularly observed occupying Lowland Deciduous Forest habitats during this period. Like the sharp-shinned hawk, this species will occasionally frequent bird feeding stations in residential areas during the winter.

\section{Red-tailed Hawk (Buteo jamaicensis)}

Status: Regular migrant, nesting species, and winter resident.

Migration: Common (locally abundant) migrant throughout the Valley. During both seasons, large numbers of migrants can be observed associated with the St. Croix River and at Crex Meadows Wildlife Area, Burnett County. Spring migration begins in mid-February in the Western Upland and Central Plain, reaching the Northern Highland about 1 March. Peak spring movements occur 20 March to 15 April, and nonbreeders have departed by 1 May. Fall migration begins in mid-August with dispersal of 
juveniles from nesting areas. Peak fall movements occur 20 September to 10 October in the Northern Highland and throughout October elsewhere. Nonwintering birds have departed by 1 December.

Nesting Season Distribution: Common nesting species in all regions, most conspicuous in agricultural areas. Nest records have been obtained for all counties except Chisago. Analysis of Breeding Bird Survey data indicate that the red-tailed hawk is the most frequently encountered breeding hawk in the Western Upland and Central Plain.

Winter: Fairly common to uncommon winter resident in the Western Upland. Uncommon to rare in the Central Plain and rare to absent in the Northern Highland. Birds normally depart the northern regions by mid-January. In open agricultural areas along the lower St. Croix River, red-tailed hawks are the most frequently encountered hawk during the winter.

Habitat: Red-tailed hawks use a large variety of habitats during the nesting season. In agricultural areas this hawk will use brushy field margins, small woodlots, and woods edge situations. In the Northern Highland, the species is usually associated with field borders of extensive Northern Deciduous Forest and Coniferous Forest. Jack Pine Barren and Lowland Deciduous Forest probably receive the lowest frequency of use by nesting red-tailed hawks.

\section{Red-shouldered Hawk (Buteo lineatus)}

Status: Regular migrant, nesting species, and winter resident. The Wisconsin DNR has listed this species as threatened (Les 1979). Habitat destruction is considered the primary reason for their decline.

Migration: Uncommon to rare migrant in the Western Upland and Central Plain; rare to absent in the Northern Highland. Spring migration begins in mid-February with a gradual movement into the Western Upland along the St. Croix River. Migrants have reached the Central Plain by 25 March (earliest-11 March 1950, 16 March 1975; Polk County). Red-shouldered hawk migration is rather diffuse, consisting primarily of movements of solitary individuals. Consequently, determination of peak dates is difficult. Most birds have reached nesting territories by mid-April. Fall migration is equally diffuse, consisting of a gradual movement from nesting areas. During fall, red-shouldered hawks are most conspicuous throughout October and nonwintering birds have departed by 1 December.

Nesting Season Distribution: Uncommon and local nesting species in the Western Upland and Central Plain, rare and local in the Northern Highland. A. C. Rosenwinkel found young in a nest along the Willow River, Pine County, on 7 April 1949 (Mierow 1949). Establishment of the red-shouldered hawk as a nesting bird in the Valley is apparently very recent. Roberts (1932) mentioned no nests from Minnesota, and cited only one summer record (3 July 1927, at Marine-on-St. Croix, Washington County). Behavior and plumage of that bird suggested nesting. Since th.t time, however, the red-shouldered hawk has been recorded regularly, and there are presently nest records for all the counties except Douglas. 
Winter: Rare and local winter resident of Lowland Deciduous Forests in the Western Upland, casual elsewhere.

Habitat: Primarily a species of medium-aged to mature Lowland Deciduous Forest. Rarely encountered away from this habitat type during the breeding season. S. D. Robbins and I recorded one red-shouldered hawk, apparently on territory, in mature black spruce habitat near Range, Polk County, on 16 March 1975.

\section{Broad-winged Hawk (Buteo platypterus)}

Status: Regular migrant and nesting species.

Migration: Fairly common spring and common fall migrant throughout the Valley. During peak fall migration, broad-winged hawks are occasionally abundant at the Crex Meadows Wildlife Area, Burnett County. Spring migrants arrive in the Western Upland and Central Plain in early April (earliest-26 March 1975, St. Croix County; 24 March 1968, Chisago County). Migrants arrive in the Northern Highland 5-10 April (earliest-21 March 1956, Burnett County). Peak spring migration occurs 15 April to 1 May, and nonbreeders depart by 20 May.

Fall migration begins in late August, with dispersal from nesting areas and formation of loose flocks. Peak fall migration occurs 10-25 September, when 400 to 500 individuals can be observed on good flight days. Movement is very rapid, and departure from the region occurs by 10 October.

Nesting Season Distribution: Common nesting species throughout the Northern Highland and northern tier of the Central Plain. Fairly common in the remainder of the Central Plain. Rare and local in the Western Upland. Nest records exist for all counties of the Valley except Pierce. In the Northern Highland, the broad-winged hawk must be considered the most abundant and conspicuous nesting raptor. Roberts (1932), quoting Surber (1919), stated that along the St. Croix River in Pine County, the broad-winged hawk was "the commonest hawk" in the region.

Habitat: Broad-winged hawks use a variety of coniferous and deciduous forest types for nesting. Regularly used habitats in the Northern Highland and Central Plain include Northern Upland Deciduous Forest, Upland Coniferous Forest, and mixed deciduous-coniferous forest. Jack Pine Barren and jack pine-oak habitats are also occupied, but to a lesser extent. Nesting broad-winged hawks have been found occupying Southern Deciduous Forest and Lowland Deciduous Forest in the Western Upland.

\section{Swainson's Hawk (Buteo swainsoni)}

Status: Casual migrant throughout the region, regular in St. Croix County. Several recent summer records.

Migration: Rare and local migrant with records from all regions. Spring migration dates range from 3 April 1965 (Burnett County) to 20 May 1967 (Pine County). Most records occur between 20 April and 15 May. Fall migra- 
tion records are fewer and range from 6 August 1975 (Burnett County) to 12 October 1968 (Polk County). Most fall migration records occur 25 August to 10 September.

Nesting Season Distribution: During June and July 1978, up to three separate pairs were observed regularly in St. Croix and northern Pierce counties. Specifically, these pairs were near Oakridge Lake and near Erin Corners in St. Croix County, and near the junction of County Highway $W$ and Highway 29, $10 \mathrm{~km}$ west of River Falls in Pierce County. Attempts to locate nests failed. These summer records are especially noteworthy because nesting occurs yearly in nearby areas of Dakota County, Minnesota (Green and Janssen 1975).

Habitat: Most Swainson's hawks observed during migration are associated with open habitats including Managed Grasslands and agricultural fields. The birds observed in June and July 1978 were in an ecotone between Managed Grassland and Southern Deciduous Forest. The Pierce County pair was using a hayfield-woods ecotone.

\section{Rough-legged Hawk (Buteo lagopus)}

Status: Regular migrant and winter resident, accidental in summer.

Migration: Fairly common migrant throughout the Valley, becoming common at Crex Meadows, Burnett County, during the fall and early winter. Fall migrants arrive about 20 September (earliest-4 September 1974, Burnett County; 15 September 1968, Pine County). Peak fall migration occurs 20 October to 15 November, with a gradual exodus from most northerly locations occurring until 1 January. Spring migration begins in late February in the Western Upland and migrants have reached the Northern Highland by 20 March. Peak spring migration occurs 15 March to 15 April and departure by 15 May (latest-7 June 1975, Burnett County; 12 June 1975, St. Croix County).

Winter: Regular winter resident in the Western Upland and Central Plain. Sporadic midwinter resident in the Northern Highland. Distribution and abundance of wintering birds is highly dependent on small mammal populations and the severity of the weather.

Habitat: Rough-legged hawks occupy open habitats almost exclusively. Edges of agricultural fields, hayfields, native grasslands, and wet meadows receive primary use. Occasionally, this hawk will be found in Northern Hardwood and Lowland Deciduous Forests.

\section{Ferruginous Hawk (Buteo regalis)}

Status: Casual fall visitor.

Records: W. Norling observed an adult at the Fish Lake Wildlife Area, Burnett County, on 25 October 1974. I observed an adult flying over the Oakridge Waterfowl Production Area, St. Croix County, on 24 September 1978. A 30 December 1967 record of a ferruginous hawk on the Suburban St. Paul 
$\mathrm{CBC}$ is questioned, primarily because of the date and because the only accompanying notes were "all field marks were noted."

\section{Golden Eagle (Aquila chrysaetos)}

Status: Regular migrant and winter resident.

Migration: Rare migrant throughout the Valley becoming uncommon at Crex Meadows, Burnett County, in the fall. Fall migration begins about 5 October; most records are from 10 October to 15 December learliest records-3 August 1976, 4 September 1974, and 15 September 1972; Crex Meadows, Burnett County). Peak migration occurs 1 November to $1 \mathrm{De}$ cember. Spring migration begins in mid-February with a gradual movement through the Valley. Peak migration occurs 1-15 March and departure by 1 April (latest-2 May 1975; Crex Meadows, Burnett County).

Winter: Very rare and local winter resident throughout the Valley. Usually the largest numbers are observed at Crex Meadows, Burnett County, where up to four individuals occur throughout the winter.

Habitat: At Crex Meadows, golden eagles are usually associated with the large areas of restored native prairie on the refuge portion of the wildlife area. Elsewhere in the Valley, wintering birds primarily use open agricultural fields.

\section{Bald Eagle (Haliaeetus leucocephalus)}

Status: Regular migrant, nesting species, and winter resident. This species is listed as threatened by the U.S. Fish and Wildlife Service. The WDNR has listed this species as endangered (Les 1979). Pesticides, nest-site destruction, and indiscriminate shooting are the main reasons for their decline.

Migration: Uncommon migrant throughout the Valley, fairly common at Crex Meadows, Burnett County. Spring migration begins in mid-February with a gradual movement from wintering areas along the lower St. Croix River. Peak spring migration occurs 10-25 March; most adults are on breeding territories by 1 April. Spring migration extends into early May; subadults arrive considerably later than adults.

Fall migration begins in late August, when juveniles move away from nesting areas. Peak fall migration occurs in two stages. Subadults reach peak numbers 1 October to 1 November and adults peak 15 October to $1 \mathrm{De}$ cember. Most birds have departed by 15 December. Largest concentrations of migrants occur at Crex Meadows, Burnett County, and in areas directly adjacent to the St. Croix River.

Nesting Season Distribution: Rare nesting species throughout the Valley; nesting has been reported in Chisago, Burnett, Douglas, Pine, Pierce, and Polk counties. The Pierce County nesting pair was associated with the lower Kinnickinnic River. The pair abandoned their territory after a June 1973 storm destroyed the nest tree. Breeding populations in the St. Croix River Valley have been monitored continuously since the mid-1960's, and there is recent evidence that the population may be increasing. 
Winter: Fairly common winter resident primarily in the vicinity of open water. Wintering birds at Crex Meadows regularly occupy open prairie areas. The distribution of wintering bald eagles closely follows the large river systems of the Valley; birds are located primarily at Prescott (Pierce and Washington counties) and St. Croix Falls (Polk and Chisago counties) along the St. Croix River, the Kettle River (Pine County), and Gordon Flowage (Douglas County).

Habitat: Nesting habitat of bald eagles consists of a complex of deciduous, coniferous, wetland, and shrub situations. In all instances, however, two prominent features (tall pine trees and nearby lakes or large rivers) occur. Unfortunately for the eagles, these are two conditions that also attract man, and several nesting territories in the Valley are endangered because of human encroachment.

\section{Marsh Hawk (Circus cyaneus)}

Status: Regular migrant and nesting species, casual winter resident.

Migration: Fairly common migrant throughout the Valley, common at Crex Meadows, Burnett County. Spring migrants arrive in the Western Upland about $15 \mathrm{March}$; average arrival is about 20 March. Migrants arrive in the Northern Highland about 25 March. Peak migration occurs 1-20 April, and nonbreeders depart by 1 May. Fall migration begins in mid-August and consists primarily of juveniles. Peak fall migration occurs 15 September to 15 October in the Central Plain and extends to 25 October at Crex Meadows. Most birds have departed by 15 November.

Nesting Season Distribution: Uncommon nesting species throughout the Valley, with nesting records for all counties. Apparently less numerous at present than earlier as evidenced by Jackson (1941), who reported them as "generally distributed... in favorable environments throughout the region." Marsh hawks have been greatly reduced as a nesting bird in west. ern Wisconsin since the mid-1960's.

Winter: Casual midwinter resident in the Western Upland. Two midwinter records for Crex Meadows, Burnett County (9 February 1954, 25 February 1953).

Habitat: Marsh hawks use a wide range of grassland habitat types for nesting. Nesting birds have been recorded in retired cropland (timothy-quackgrass), old field habitat, wetlands (primarily sedge meadows), and restored prairie. In areas of intensive agriculture, nesting may regularly occur in hayfields and occasionally in oat fields.

\section{FAMILY PANDIONIDAE: Ospreys}

\section{Osprey (Pandion haliaetus)}

Status: Regular migrant and nesting species. The WDNR listed the species as endangered (Les 1979). Residual pesticides and loss of nesting habitat are 
considered reasons for their decline.

Migration: Uncommon migrant throughout the Valley, most regularly observed adjacent to the St. Croix River. Spring migrants arrive during the second week of April (earliest-22 March 1953, Burnett County and 26 March 1967, Washington County). Peak abundance of spring migrants occurs between 25 April and 5 May. Fall migration begins with departure from nesting areas in mid-August. Peak fall migration occurs 25 August to 15 September and departure by 10 October (latest-23 November 1968, Chisago County).

Nesting Season Distribution: Ospreys are rare and local nesting species north of St. Croix and Washington counties. The largest concentration of breeding adults is near the Crex Meadows Wildlife Area in Burnett County. Sindelar (1971) observed at least four nests in Burnett and three in Polk counties in the late 1960's.

Winter: M. R. Olson observed an osprey near Hudson, St. Croix County, on 31 December 1970.

Habitat: Nesting ospreys use a variety of habitat types including acid bogs, open lakes, and riverbanks. One of the most important habitat requirements is the presence of dead trees used for nest sites. Variations occur in the size of the water body that attracts breeding pairs. Most breeding pairs I have observed nest near a small lake (usually $<20 \mathrm{ha}$ ), within $1.6 \mathrm{~km}$ of larger lakes. Large bodies of water within proximity of a nesting site serve as important feeding areas for nesting ospreys.

\section{FAMILY FALCONIDAE: Falcons}

\section{Gyrfalcon (Falco rusticolus)}

Status: Accidental, one record.

Record: One was observed near Marine-on-St. Croix, Washington County, on 24 December 1973 (Honetschlager 1974).

\section{Peregrine Falcon (Falco peregrinus)}

Status: Regular migrant and former nesting species. The U.S. Fish and Wildlife Service and WDNR (Les 1979) have listed this species as endangered. Pesticides, habitat loss, and human harassment are among the major causes of the decline.

Migration: Rare migrant throughout the Valley. Spring migrants arrive in the Western Upland 10-15 April (earliest-4 April 1974, Pierce County) and the Northern Highland 15-20 April. Departure from the Valley occurs 15-20 May. Fall migrants arrive 5-10 September and most observations occur during 15-30 September and departure by 15 October. During fall migration, the restored prairie on the refuge portion of Crex Meadows is the most consistent area in the Valley to observe this raptor. 
Nesting Season Distribution: Formerly a rare and local nesting bird along the St. Croix River. Roberts (1932) reported that fewer than six pairs nested along the upper St. Croix River in the late 1920's. Surber (1919) reported a pair of peregrine falcons along the St. Croix River near the mouth of the Tamarack River (Pine County) during July 1918. Jackson (1941) did not report this species during the 1919 nesting season in northwestern Wisconsin. Apparently the last known nesting attempt occurred along "the upper St. Croix River" in 1945 (Green and Janssen 1975).

Habitat: Roberts' (1932) description of peregrine falcons nesting "along the bluffs" of the St. Croix River is all that is known of their nesting habitat in the Valley. Peregrine falcons presumably nested on the relatively inaccessible rock ledges on the sides of the steepest bluffs. During migration, most peregrine falcons are observed in association with mudflats on large natural and man-made wetlands. Open mudflats support migrant shorebirds and waterfowl and provide excellent hunting for falcons.

\section{Merlin (Falco columbarius)}

Status: Regular migrant and casual summer resident.

Migration: Rare migrant throughout the Valley. Spring migrants arrive in the Western Upland about 5-10 April and the Northern Highland 10-15 April. During spring migration the merlin is most frequently observed 1-15 May and departs by 25 May (latest-28 May 1977, St. Croix County). Fall migrants arrive 25 August to 5 September and are most frequently observed 10-25 September. Departure from the Northern Highland occurs 1-10 October and elsewhere by 20 October.

Nesting Season Distribution: Casual summer resident, restricted to the Northern Highland. Jackson (1941) mentioned the observation of an adult at Gordon (Douglas County) on 28 July 1919. I observed an adult merlin near Moose Junction (Douglas County, Sec. 14, T. 44 N., R. 15 W.) on 30 June 1975 and 8 July 1977 . Both observations were of lone birds. These dates provide speculation of possible nesting, although neither nests nor young have been observed.

Habitat: My Douglas County observations were made in a large stand of Lowland Coniferous Forest. Predominant vegetation included trembling aspen, green ash, black spruce, and balsam fir. These vegetative characteristics are usually associated with merlin breeding habitat in their normal breeding range in the boreal forest region of southern Canada. During migration, merlins regularly use a variety of both open and forested habitats.

\section{American Kestrel (Falco sparverius)}

Status: Regular migrant, nesting species, and winter resident.

Migration: Abundant migrant in the Western Upland and Central Plain, common in the heavily forested regions of the Northern Highland. Spring 
migrants arrive in the Western Upland about 5-15 March and the Northern Highland 25 March to 5 April. Peak abundance through the Valley occurs 10-25 April. Fall migration begins in mid-August and peak abundance occurs 1-15 September. Most fall migrants have departed the Northern Highland by 15 October and elsewhere by 15 November.

Nesting Season Distribution: Common nesting species in the Western Upland and Central Plain, uncommon and more local in the Northern Highland.

Winter: Casual midwinter resident in the Central Plain and Western Upland.

Habitat: Primarily associated with scattered tree groves in agricultural areas, brushy edges of deciduous forest, and Old Field Community in southern areas. In the Northern Highland, American kestrels use edge situations associated with agricultural clearings, and areas that are managed for wildlife production. Wintering American kestrels are usually found along roadsides hunting from transmission wires and occasionally near feeding stations in residential areas.

\section{FAMILY TETRAONIDAE: Grouse}

\section{Spruce Grouse (Canachites canadensis)}

Status: Formerly a permanent resicent, two recent records.

Distribution: Scott (1943b) reported that spruce grouse were last reported in 1928 or 1929 from the town of Dairyland (T. 43 N., R. 14 W.), Douglas County. Scott believed that at one time this species probably occurred throughout northern Wisconsin and south along the St. Croix River. The presumed range in Wisconsin extended south to central Polk County. Despite the presence of suitable spruce habitats in Pine County, this species is not known south of central St. Louis County in Minnesota (Green and Janssen 1975).

On 26 May 1978, R. Hoffman (personal communication) observed one spruce grouse in Sec. 33, T. 42 N., R. 15 W., Burnett County. Returning to the same area on 4 September 1978, Hoffman again observed a single spruce grouse.

Habitat: Scott $(1943 b)$ reported that spruce grouse are "almost always found only in spruce-balsam swamps" (= Lowland Coniferous Forest).

\section{Ruffed Grouse (Bonasa umbellus)}

Status: Regular permanent resident.

Distribution: Common resident in the Northern Highland and in the northern half of the Central Plain. Fairly common in the oak forests of the Central Plain and Western Upland. Breeding populations experience yearly fluctua- 
tions that are almost predictable. Attempts to correlate these fluctuations with changes in food availability have proved unsuccessful thus far.

Habitat: Nesting ruffed grouse occur in a variety of upland deciduous forest types. In the Northern Highland and parts of the Central Plain, ruffed grouse are most commonly associated with medium-aged aspen forests that contain scattered openings. In the Western Upland and areas of the Central Plain adjacent to the St. Croix River, nesting ruffed grouse are associated with medium-aged oak forests and woodlots. A well-developed shrub layer consisting of prickly ash, thorn apple, and beaked hazel is usually associated with high-quality ruffed grouse habitat.

\section{Greater Prairie Chicken (Tympanuchus cupido)}

Status: Extirpated as a natural breeding species; reintroduced in 1974.

Former Distribution: Until the late 1890 's, the greater prairie chicken was an abundant species on the prairies of Pierce and St. Croix counties and ranged north to Grantsburg, Burnett County. Schorger (1943) summarized numerous accounts of the status of this species including newspaper accounts of abundance. Populations appeared to remain at high levels through 1865. The winter of 1873 was reportedly very severe and St. Croix County farmers reported the winter was extremely hard on the greater prairie chicken. Populations fluctuated considerably after 1875.

Reduced numbers of greater prairie chickens remained in St. Croix County until the 1920's, although they were still well distributed between Hammond and New Richmond. The last greater prairie chicken observed in St. Croix County was shot near Hammond in 1932. At Crex Meadows, the last greater prairie chicken reported on a booming ground was observed in April 1949.

Former status of the greater prairie chicken in the Minnesota counties is poorly known. Roberts (1932) made no reference to this species in three counties considered in the present report. Greater prairie chickens were known to breed in the vicinity of the Twin Cities at the time of Roberts. A limited amount of information is provided by Partch (1970) in summarizing the demise of this species in central Minnesota. Partch shows that greater prairie chickens were common or abundant in southern Washington County in 1849. Dispersal north through the Valley probably happened in the "late 1800 's." This movement northward along the St. Croix was attributed to logging and fires creating favorable openings in sandy areas. Surber (1919), in describing an area of Pine County, stated that greater prairie chickens near Hinckley occurred "in goodly numbers" in 1919. He made an appeal to local residents to report illegal shooting so the "overflow" (of chickens) into surrounding areas would manifest another hunting season.

Current Distribution: The WDNR began a greater prairie chicken reintroduction program at Crex Meadows during October 1974. This project met with limited success during the first 2 years. In 1977, at least one female was observed with a brood near the original release site. Continued research and habitat management at Crex Meadows may prove essential in the restoration of this species in portions of its former breeding range. 


\section{Sharp-tailed Grouse (Pedioecetes phasianellus)}

Status: Regular permanent resident.

Distribution: Sharp-tailed grouse were formerly well distributed throughout the Valley, with nest records from Pine, Polk, and St. Croix counties. Currently sharp-tailed grouse occur in northern Polk, central Burnett, eastern and central Pine, and southwestern Douglas counties. The largest breeding populations occur at Crex Meadows, Burnett County, and on the sharptailed grouse management area near Solon Springs, Douglas County. Dancing ground surveys from Crex Meadows indicate a fairly stable population, with at least eight active dancing grounds in 1976 (WDNR files).

Away from the center of the sharp-tailed grouse breeding range, this species is still occasionally observed in St. Croix County. A flock of 12 was observed near Roberts on 13 October 1976, and a single bird observed near Star Prairie on 1 November 1977.

Habitat: Sharp-tailed grouse are characteristic of mixed grasslands containing small groves of oak or aspen trees or shrubs. At the grouse management area in Douglas County, small patches of jack pine are commonly interspersed with grasslands. Most well-known sharp-tailed grouse breeding habitat in the Valley is characterized by restored prairie grasses on loose sandy soils.

\section{FAMILY PHASIANIDAE: Quails and Pheasants}

\section{Bobwhite (Colinus virginianus)}

Status: Regular permanent resident.

Distribution: The Valley is at the extreme northern limit of the bobwhite range. A very rare resident, restricted to Washington, St. Croix, and Pierce counties. Recent summer records from Crex Meadows in Burnett County are probably released birds. Additionally, Green and Janssen (1975) report records of bobwhites in Pine County. Habitat loss coupled with winter stress have created a severe impact on bobwhite populations.

Habitat: Primary bobwhite habitat includes retired agricultural fields and Old Field Community intermixed with hedgerows and scattered shrubs. Much of this habitat continues to be altered or destroyed by expanding agricultural and urban development.

\section{Ring-necked Pheasant (Phasianus colchicus)}

Status: Introduced permanent resident.

Distribution: Fairly common resident of the Western Upland and Central Plain, rare to absent in the Northern Highland. Ring-necked pheasants were first introduced in western Wisconsin during the 1930's. Populations remained fairly stable through the 1950 's and 1960 's, primarily because of yearly releases by State wildlife agencies. Currently, ring-necked pheasant 
populations are reduced because of farming practices that eliminated most of their habitat. Urban expansion has not impacted this species to nearly the extent that agricultural production has. Green and Janssen (1975) stated that the largest populations remaining in Minnesota exist in the Twin Cities metropolitan area.

Habitat: The ring-necked pheasant is a species of agricultural areas, primarily edge habitats including field margins, fencerows, retired cropland, Old Field Communities, and heavily vegetated wetlands. Ring-necked pheasants in the Central Plain have shown an encouraging response to Managed Grasslands that are maintained for duck production.

\section{Gray Partridge (Perdix perdix)}

Status: Introduced permanent resident.

Distribution: Rare resident of the Western Upland. The small population that exists in the Valley is largely restricted to a small area of central St. Croix County. The largest population occurs near the village of Roberts in $\mathrm{T}$. 29 N., R. 18 W.; T. 29 N., R. 17 W.; and T. 30 N., R. 17 W. Distribution of the population in the Minnesota counties is poorly known, although Mettler (1977) showed that the species range included southern Washington County. McCabe and Hawkins (1946) reported a population density of 0.6 coveys per $62 \mathrm{~km}$ in St. Croix County.

Habitat: The gray partridge is primarily a species of croplands and adjoining edge habitat. Preferred habitats include corn and oats fields, weedy edges of summer fallow, and remnant patches of native prairie along railroad rights-of-way that border agricultural fields.

\section{FAMILY GRUIDAE: Cranes}

\section{Sandhill Crane (Grus canadensis)}

Status: Regular migrant and nesting species.

Migration: Rare migrant throughout the Valley, locally common at Crex Meadows, Burnett County. Sandhill cranes have been observed in Washington County on four occasions: 31 March 1967, 9 April 1970 and 1971, and 20 November 1970. Three records exist for St. Croix County: 17 April 1947, 4 May 1974, and 30 October 1977. There is one record (29 April 1950) for Polk County.

The most reliable data on migration is from Crex Meadows, where the average date of spring arrival is 4 April (earliest-25 March 1976). Peak spring concentration occurs about 20 April. During fall migration, the first migrants arrive in early September and peak abundance is 15 October to 1 November. During this period, concentrations of 150 to 200 individuals commonly occur on the refuge portion of Crex Meadows; high counts were 350 on 19 October 1975 and 420 on 30 October 1977. Departure of fall migrants occurs soon after freeze-up; the latest was on 18 November 1962. 
Nesting Season Distribution: The first reported nesting in the Valley occurred in the Kohler-Peet area north of Crex Meadows along the St. Croix River in 1903. Roberts (1932) mentioned a local farmer reported sandhill cranes nesting in Burnett County from 1904 through 1930. Recent summer observations indicate that cranes still probably nest at Kohler-Peet; however, nests or young have not been observed.

Currently, sandhill cranes are fairly common during the nesting season at Crex Meadows. Recent surveys indicate that 30 to 40 pairs are nesting at that location. Elsewhere, Green and Janssen (1975) cited a 1950 nest record near Beroun, Pine County. Johnson (1976) reported breeding season sandhill cranes in Thunder Meadow and the St. Croix River marshes, Pine County, and in the extensive marshes of the Carlos Avery Wildlife Management Area, Chisago County, during 1974 75. Henderson (1978) showed that breeding season sandhill cranes occurred in three Pine County townships: $\mathrm{T}$. 42 N., R. 16 W.; T. 41 N., R. 13 W.; and T. 38 N., R. 17 W.

Habitat: Breeding sandhill cranes are typically associated with large expanses of Northern Sedge Meadow characterized by tussock sedge, bristly sedge, fox sedge, bluejoint grass, rattlesnake grass, marsh cinquefoil, and marsh bellflower.

\section{FAMILY RALLIDAE: Rails, Gallinules, and Coots}

\section{King Rail (Rallus elegans)}

Status: Casual spring migrant and nesting species.

Migration: Rare spring migrant near the St. Croix River. Spring arrival dates range from 24 April 1977 in St. Croix County to 9 May 1958 in Burnett County. Fall migration records are not available.

Nesting Season Distribution: Observations at Crex Meadows, Burnett County, include 12 June 1969, 25 June 1975, 27 and 28 June 1956, 3 July 1963 , and 12 August 1970. These breeding season records suggest possible nesting although nests or young have not been found. In St. Croix County, I observed a male king rail at East Twin Lake on 17 June 1976. Green and Janssen's (1975) Washington County record is the only confirmed nesting observation in the Valley.

Habitat: King rails at Crex Meadows are usually associated with dense cattail vegetation in man-made impoundments.

\section{Virginia Rail (Rallus limicola)}

Status: Regular migrant and nesting species, one winter record.

Migration: Common migrant in St. Croix, Polk, and Washington counties, uncommon to rare elsewhere. Spring migrants arrive about 25 April (earliest-16 April 1958, Burnett County): peak abundance is 10-15 May. Peak fall migration occurs between 20 September and 1 October and departure by 30 October. 
Nesting Season Distribution: Fairly common nesting species in prairie wetlands of St. Croix, Polk, and Washington counties. Uncommon to rare nesting species elsewhere in the Valley. One nest record was reported for Pine County in 1969 (Russell 1969).

Winter: One individual was observed on 30 December 1978 in Washington County (Suburban St. Paul CBC).

Habitat: Virginia rails use a variety of wetland classes for nesting. Greatest densities occur in seasonally and semipermanently flooded wetlands with cattail, river bulrush, and phragmites the predominant vegetation. Nesting Virginia rails are occasionally found in Northern Sedge Meadow habitats, along well-vegetated streams and in Shrub Carr wetlands.

\section{Sora (Porzana carolina)}

Status: Regular migrant and nesting species.

Migration: Common migrant in prairie wetlands of St. Croix, Polk, and Washington counties and at Crex Meadows in Burnett County. Fairly common to uncommon elsewhere. Spring migrants arrive about 25 April (earliest-6 April 1964, Burnett County), reaching peak abundance 15-20 May. Peak abundance during fall migration occurs 10 September to 10 October and departure by 5 November.

Nesting Season Distribution: Common nesting species in prairie wetlands in the Western Upland and Central Plain, and at Crex Meadows. Uncommon elsewhere.

Habitat: Soras use a variety of wetland types for nesting. Highest densities occur in seasonally and semipermanently flooded wetlands where cattail, river bulrush, and softstem bulrush are the predominant vegetation types. Soras also use wetlands that are more acidic, containing various species of waterlilies and pickerelweed. During high water periods, nesting soras also use sedge meadows.

\section{Yellow Rail (Coturnicops noveboracensis)}

Status: Casual migrant and summer resident.

Migration: S. D. Robbins observed this species twice in central St. Croix County: 26 April 1961 and 17 May 1963. At Crex Meadows, Burnett County, apparent migrants were observed on 25 May 1976, 30 May 1977, and 28 May 1978. R. Hoffman observed one at the Fish Lake Wildlife Area, Burnett County, on 26 May 1979.

Nesting Season Distribution: The first record of the yellow rail in the Valley was obtained on 23 June 1962, when N. R. Stone observed a single bird at Crex Meadows (Robbins 1963). During the summers of 1976 and 1977, yellow rails were again heard calling in a large Northern Sedge Meadow at Crex Meadows. Although these birds were observed during normal nesting periods, neither nests nor young were observed. Continued observations at 
Crex Meadows may shed additional light on the breeding status of this species.

\section{Common Gallinule (Gallinula chloropus)}

Status: Casual migrant and nesting species.

Spring Records: Gallinules were observed at Crex Meadows, Burnett County, on 9 May 1958 and 10 May 1976. In St. Croix County spring records include 16 May 1961 and 25 May 1976. Washington County records range from 15-30 May.

Nesting Season Distribution: Green and Janssen (1975) showed a nesting record for Washington County. Since 1975, I have found common gallinule during the nesting season near Lake Elmo, Washington County. In Wisconsin, one bird was observed at Crex Meadows on 11 June 1958. The first St. Croix County nesting record was obtained on 9 July 1976 near Star Prairie. On 14 July 1977 an adult with a brood of three was observed on a wetland near Hudson. Additionally, a single adult was observed near Roberts on 11 August 1975.

Habitat: Most common gallinules observed during the nesting season are associated with seasonally and semipermanently flooded wetlands. These wetlands typically support an abundant submerged and emergent flora.

\section{American Coot (Fulica americana)}

Status: Regular migrant and nesting species, casual in winter.

Migration: Abundant migrant throughout the Valley. Spring migrants arrive in the Western Upland about 10 March reaching the Northern Highland 1-10 April. Peak spring abundance occurs between 20 April and 1 May. The first fall migrants arrive between 1 and 10 September. Peak fall abundance occurs 25 September to 10 October and departure by 15 November.

Nesting Season Distribution: Common nesting species on prairie wetlands in St. Croix, Polk, and Washington counties. Fairly common nesting species at Crex Meadows in Burnett County. Uncommon to rare elsewhere during the nesting season.

Winter: Casual early winter resident along the St. Croix River. Afton CBC records include one each on 1 January 1957, 1971, 1972, 1974, and 1975. I observed one along the Apple River, St. Croix County, on 19 December 1977. During the winter of 1975-76, a single bird remained on the St. Croix River near Bayport, Washington County.

Habitat: American coots are characteristic of seasonally and semipermanently flooded wetlands. Predominant vegetation associated with American coot nesting habitat includes cattail, river bulrush, softstem and hardstem bulrush, burreed, and phragmites. Nesting also occurs to a more limited extent on lower quality acidic wetlands characterized by waterlily and pickerelweed. Very few nesting pairs are found on riverine habitats. 
FAMILY RECURVIROSTRIDAE: Stilts and Avocets

\section{American Avocet (Recurvirostra americana)}

Status: Casual migrant.

Records: There are three records from Crex Meadows, Burnett County: 30 April 1971, 16 May 1977, and 22 August 1965. One American avocet was observed in St. Croix County near New Richmond on 13 May 1973.

\section{FAMILY CHARADRIIDAE: Plovers}

\section{Semipalmated Plover (Charadrius semipalmatus)}

Status: Regular migrant.

Migration: Fairly common migrant in the Western Upland and Central Plain, rare to absent in the Northern Highland. The first spring migrants arrive 25 April to 1 May (earliest-19 April 1976, St. Croix County). Peak abundance occurs 10-20 May and departure by 25 May. The first fall migrants arrive between 25 July and 1 August. Peak fall populations occur 20 August to 1 September and departure by 25 September.

Habitat: Most common on seasonally flooded wetlands. Uncommon on lakeshores and in short vegetation associated with semipermanently flooded wetlands.

\section{Piping Plover (Charadrius melodus)}

Status: Accidental, two records.

Records: S. D. Robbins observed a single piping plover near Roberts, St. Croix County, from 3 to 15 May 1967 (Robbins 1968). S. V. Goddard found one on the same wetland on 12 May 1972 (Faanes and Goddard 1976).

\section{Killdeer (Charadrius vociferus)}

Status: Regular migrant and nesting species, casual in early winter.

Migration: Abundant migrant in the Western Upland and Central Plain, common and more local in the Northern Highland. Spring migrants arrive about 15 March (earliest-2 March 1961, Burnett County); peak abundance is 10-25 April. Fall migration begins about 10 August. Peak abundance occurs 1-15 September and departure by 1 November.

Nesting Season Distribution: Common nesting species in the Western Upland and Central Plain, uncommon to rare and local in the Northern Highland.

Winter: There are eight early winter records for an area in Washington County; the dates are from 15 to 30 December. S. D. Robbins observed one 
in St. Croix County on 16 January 1964.

Habitat: Killdeer use a variety of habitats ranging from cropland, summer fallow, pastures, shorelines, and lawns to flat-topped roofs in residential areas.

\section{American Golden Plover (Pluvialis dominica)}

Status: Regular migrant.

Migration: Fairly common spring and rare fall migrant in the Western Upland, locally common during spring migration at Crex Meadows, Burnett County. Rare to absent elsewhere. Spring migrants arrive 20-25 April. Peak abundance occurs 10-15 May and departure by 1 June. Fall migrants arrive about 20 August and have departed by 15 October (latest-2 November 1965, St. Croix County).

Habitat: Most commonly observed in temporarily flooded cornfields, alfalfa, or oat stubble, and are less common on mudflats and lakeshores. This plover uses habitat that is fairly dry and usually away from the edge of wetland basins.

\section{Black-bellied Plover (Pluvialis squatarola)}

Status: Regular migrant.

Migration: Uncommon migrant in the Western Upland and Central Plain. Locally common during spring at Crex Meadows, Burnett County, rare to absent in the Northern Highland. Spring migrants arrive about 5 May (earliest-15 April 1975, St. Croix County). Peak abundance occurs 15-20 May and departure by 1 June. Fall migrants arrive 10-20 August. Peak abundance occurs 5-20 September and departure by 15 October (latest-3 November 1976, St. Croix County).

Habitat: Unlike the preceding species, the black-bellied plover commonly uses temporarily flooded wetlands. Less common on flooded alfalfa or oat stubble and along the edge of semipermanently flooded wetlands.

FAMILY SCOLOPACIDAE: Sandpipers and Phalaropes

\section{Hudsonian Godwit (Limosa haemastica)}

Status: Regular migrant.

Migration: Rare spring migrant in the Western Upland and at Crex Meadows, Burnett County. Most records are from central St. Croix and eastern Washington counties. There are no fall records. The first migrants arrive 5-10 May. Flocks as large as 40 individuals have been observed 15-20 May and departure occurs by 30 May.

Habitat: Most individuals are observed on temporarily flooded agricultural 
fields. Occasional use is made of flooded alfalfa fields and edges of man-made impoundments.

\section{Marbled Godwit (Limosa fedoa)}

Status: Regular migrant.

Migration: Rare and local migrant in the Western Upland and at Crex Meadows, Burnett County; most records are from central St. Croix County. Spring migrants arrive about 20 April. Peak numbers (five to seven) occur 1-10 May; departure is by 25 May. Fall migrants arrive about 25 July and depart by 1 September. W. Norling observed an injured marbled godwit at Grettum Flowage, Burnett County, on 8 November 1975.

Habitat: Observed primarily on temporarily flooded agricultural fields and along the edge of seasonally flooded wetlands.

\section{Whimbrel (Numenius phaeopus)}

Status: Accidental, one record.

Record: I observed one whimbrel along the north shore of East Twin Lake near Roberts, St. Croix County, on 17 May 1976.

\section{Long-billed Curlew (Numenius americanus)}

Status: Accidental, one record.

Record: N. R. Stone observed one long-billed curlew at Crex Meadows, Burnett County, on 25 May 1966 (Stone 1967).

\section{Upland Sandpiper (Bartramia longicauda)}

Status: Regular migrant and nesting species.

Migration: Rare spring and fall migrant in the Western Upland and Central Plain, casual to absent elsewhere. Spring migrants arrive 20-25 April. Because most observations are of solitary or paired birds, dates of peak abundance are difficult to establish. Fall migrants begin to arrive in late July and have departed by 15 September.

Nesting Season Distribution: Rare and local nesting species in suitable grass habitat in the Western Upland and Central Plain, locally common at Crex Meadows, Burnett County, and at the Sharp-tailed Grouse Management Area near Solon Springs, Douglas County. The latter site has been used since at least 1919, when Jackson (1942) found "a dozen or more." Green and Janssen (1975) considered the upland sandpiper "very scarce" in Pine County. One nest was found in Washington County in 1971. In northern Pierce and central St. Croix counties, this species was fairly common until 1972. Increased conversion of remaining grasslands, primarily related to 
ending the Soil Bank Program, has caused their apparent extirpation in these two counties.

Habitat: Characteristic nesting species of tallgrass prairie such as at the Sharp-tailed Grouse Area, Douglas County, and in sedge meadows. Also regularly observed in unmowed alfalfa and timothy fields.

\section{Greater Yellowlegs (Tringa melanoleucus)}

Status: Regular migrant.

Migration: Fairly common migrant in the Western Upland and Central Plain, uncommon in the Northern Highland. Spring migrants arrive 30 March to 10 April. Peak abundance occurs 20 April to 5 May and departure by 25 May. The first fall migrants arrive about 10 July (earliest3 July 1963, Burnett County). Peak abundance occurs 10-20 August, and departure by 30 October (latest-7 November 1975 and 10 November 1963 , Burnett County).

Habitat: Greater yellowlegs occur in a variety of wetlands, flooded grasslands, plowed agricultural fields, Northern Sedge Meadow, and along the edge of seasonally, semipermanently, and permanently flooded wetlands. Primary use is made of flooded agricultural fields.

\section{Lesser Yellowlegs (Tringa flavipes)}

Status: Regular migrant.

Migration: Common to locally abundant migrant in the Western Upland and Central Plain, uncommon and local in the Northern Highland. Spring migrants arrive in the Western Upland 30 March to 5 April and the Northern Highland 10-15 April. Peak abundance occurs 1-10 May and departure by 30 May. The first fall migrants arrive about 10 July (earliest-4 July 1975, St. Croix County and 5 July 1960, Burnett County). Peak abundance occurs 1-10 August and departure by 15 October (latest-8 November 1975 and 10 November 1963, Burnett County).

Habitat: Lesser yellowlegs occur in a variety of wetland types, flooded alfalfa fields, and agricultural fields. Primary use is made of flooded agricultural fields.

\section{Solitary Sandpiper (Tringa solitaria)}

Status: Regular migrant.

Migration: Uncommon migrant in the Western Upland and Central Plain, rare and local in the Northern Highland. Spring migrants arrive 25-30 April. Peak abundance occurs from 5-15 May and departure by 25 May. Fall migrants arrive 5-15 July. Peak fall abundance occurs 25 July to 20 August and departure by 25 September (latest-10 October 1969 , Washington County). 
Habitat: Primarily found on flooded agricultural fields and the muddy edges of wetlands. This species is occasionally observed in Northern Sedge Meadow and Shrub Carr wetlands.

\section{Willet (Catoptrophorus semipalmatus)}

Status: Regular migrant.

Migration: Rare migrant in the Western Upland, casual elsewhere. Spring migrants arrive about 30 April. Willets are most frequently observed 5-10 May and remain through 25 May. The first fall migrants arrive about 25 July and have departed by 1 September.

Habitat: Willets are found primarily on temporarily and seasonally flooded wetlands. K. H. Dueholm observed a flock of 20 in a flooded alfalfa field in Polk County on 30 April 1975.

\section{Spotted Sandpiper (Actitis macularia)}

Status: Regular migrant and nesting species.

Migration: Common migrant in the Western Upland and Central Plain, uncommon and local in the Northern Highland. Spring migrants arrive in the Western Upland 20-30 April (earliest-2 April 1953, Burnett County) and peak abundance occurs 5-15 May. Peak fall abundance occurs during mid-August and departure by 1 October.

Nesting Season Distribution: Fairly common nesting species throughout the Valley. Nest records and observations of breeding pairs have been obtained from all the counties.

Habitat: Primarily a nesting species of seasonally, semipermanently, and permanently flooded wetlands in the Western Upland and Central Plain. This species also makes extensive use of river edge and exposed islands in larger streams. Largely restricted to rivers, streams, and rocky or sandy shores of large lakes in the Northern Highland.

\section{Ruddy Turnstone (Arenaria interpres)}

Status: Regular migrant.

Migration: Rare and local migrant throughout the Valley. Spring migrants arrive about 10 May and are most commonly observed 15-25 May. Departure occurs by 5 June (latest-10 June 1972, Burnett County). The observation of 18 ruddy turnstones on Lake Chisago, Chisago County (Roberts 1938), constitutes the largest group reported in the Valley. Fall migrants arrive about 20 August and have departed by 20 September.

Habitat: Ruddy turnstones primarily use sandy beaches associated with large lakes and the shoreline of the St. Croix River. Occasional use is made of seasonally flooded wetlands. 


\section{Wilson's Phalarope (Steganopus tricolor)}

Status: Regular migrant and summer resident, one nest record.

Migration: Fairly common migrant in the Western Upland, locally common in St. Croix County. Rare and local in the Central Plain and Northern Highland. Spring migrants arrive 20-25 April. Peak abundance occurs 10-15 May and departure by 1 June. The first fall migrants arrive 20-30 July. Peak abundance occurs 10-25 August and departure by 15 September.

Nesting Season Distribution: I observed an adult male with at least two young that still retained some down feathers on 10 July 1978 in St. Croix County. The wetland where this brood was observed (Sec. 11, T. 29 N., R. $18 \mathrm{~W}$.) occasionally supports breeding plumaged adults during the nesting season in wet years. Numerous nesting season records from this wetland ranging from 9 June (1964) to 17 July (1961) suggest that nesting may have occurred earlier. Summer records from Crex Meadows, Burnett County (26 June 1974 and 27 June 1972), suggest that Wilson's phalarope may also nest at that location.

Habitat: Wilson's phalaropes use several wetland types during migration, including seasonally and semipermanently flooded wetlands. Summer records are from wetlands where cattail and river bulrush are the predominant vegetation types.

\section{Northern Phalarope (Lobipes lobatus)}

Status: Regular migrant.

Migration: Rare migrant in the Western Upland and at Crex Meadows, Burnett County. Casual elsewhere. Spring migrants arrive about 10 May (earliest-30 April 1974 and 1 May 1975, St. Croix County). Northern phalaropes are most commonly observed during the third week of May and depart by 5 June. Fall migrants arrive in mid-August (earliest-20 July 1975, St. Croix County) and depart by 15 September.

Habitat: Northern phalaropes are usually observed on semipermanently and permanently flooded wetlands that have poorly developed shoreline or emergent aquatic vegetation.

\section{American Woodcock (Scolopax minor)}

Status: Regular migrant and nesting species.

Migration: Common migrant throughout the Valley. Spring migrants arrive about 25 March (earliest-14 March 1951, Polk County and 17 March 1955, Burnett County) and peak abundance occurs 20 April to 1 May. Fall migration begins in mid-August. Peak fall abundance occurs 15 September to 1 October and departure by 1 November.

Nesting Season Distribution: Fairly common and well distributed nesting 
species. Nesting has been recorded in all counties. Surber (1919) made reference to the abundance of this species in Pine County during the early 1900 's.

Habitat: American woodcock use a variety of habitats for nesting. In the Western Upland, nesting birds use mesic Southern Deciduous Forest and Lowland Deciduous Forest. In the Central Plain and Northern Highland, open stands of medium-aged aspen and maple forest and Alder Thickets provide optimum nesting habitat. Recently, Deciduous Clear Cuts have been found to provide important nesting habitat.

\section{Common Snipe (Gallinago gallinago)}

Status: Regular migrant and nesting species, casual in winter.

Migration: Common to locally abundant migrant throughout the Valley. Spring migrants arrive in the Western Upland about $20 \mathrm{March}$, reaching the Northern Highland about 1 April. Peak abundance during spring migration occurs 20 April to 1 May. Fall migration begins with the flocking of family groups in mid-August. Peak abundance occurs between 25 September and 10 October and departure by 15 November.

Nesting Season Distribution: Uncommon nesting species in the Western Upland, common in the Central Plain and Northern Highland. Confirmed nest records have been obtained from Burnett and Polk counties.

Winter: There are eight late December records ranging from 19 December (1976) to 3 January (1976) in St. Croix and Washington counties. These are all CBC records. The largest count was 12 individuals on the Suburban St. Paul CBC, 30 December 1961. There is only one midwinter record (15 February 1973, Pierce County) for the Valley.

Habitat: Highest densities of nesting common snipe occur in Northern Sedge Meadow. Stream banks and semipermanently flooded wetlands provide important habitat in the Central Plain and Western Upland. In the Northern Highland, breeding common snipe use openings in Black Spruce-Tamarack Bogs and Alder Thicket, in addition to Northern Sedge Meadow.

\section{Short-billed Dowitcher (Limnodromus griseus)}

Status: Regular migrant.

Migration: Uncommon to rare migrant throughout the Valley. Most records are from the Western Upland and from Crex Meadows, Burnett County. Spring migrants arrive about 10 May and have departed by 30 May. Fall migrants arrive about 25 July (earliest-9 July 1965, St. Croix County) and have departed by 15 September. A short-billed dowitcher that I banded near Roberts, St. Croix County, on 16 August 1975 was recovered in Guyana, South America, in September 1976. Identification of this species and the long-billed dowitcher is compounded by nearly identical plumage characteristics. 
Habitat: Largely restricted to flooded alfalfa and stubble fields and borders of seasonally and semipermanently flooded wetlands.

\section{Long-billed Dowitcher (Limnodromus scolopaceus)}

Status: Regular migrant.

Migration: Uncommon migrant in the Western Upland and Central Plain, rare to absent in the Northern Highland. Spring migrants arrive in the Western Upland 20-25 April and the Northern Highland about 1 May. This species is most frequently observed about 10 May and departs by 15 May. Fall migrants arrive about 10 August (earliest-17 July 1976, St. Croix County). Peak abundance occurs 25 August to 5 September and departure by 5 October (latest-25 and 28 October 1960, St. Croix County; Robbins 1961).

Correct identification of both dowitcher species is difficult because of their similar appearance. To assure positive identification, recognition of their call notes is important. The long-billed dowitcher has a short, two-note "twee twee" call. The short-billed dowitcher call consists of three notes in close succession. This call, "tu-tu-tu," is similar to the greater yellowlegs.

Habitat: Primarily a species of flooded agricultural fields, temporarily, seasonally, and semipermanently flooded wetlands.

\section{Red Knot (Calidris canutus)}

Status: Casual migrant.

Records: Single red knots were observed in St. Croix County on 12 May 1966 and 13 May 1975. Three birds were observed at Crex Meadows, Burnett County, on 19 May 1972, and single birds on 13 June 1968 and 17 August 1960 (Kemper 1961).

\section{Sanderling (Calidris alba)}

Status: Regular migrant.

Migration: Rare spring and very rare fall migrant in the Western Upland and at Crex Meadows, Burnett County; absent in the northern forested regions. Spring migrants arrive about 10 May (earliest-30 April 1973, St. Croix County and 2 May 1969, Washington County) and have departed by 30 May. Fall migration is between 15 August and 10 September.

Habitat: Sanderlings are primarily found on sandy or rocky beaches associated with large lakes and sandbars on the St. Croix River. Occasional use is made of drier portions of exposed mud associated with seasonally flooded wetlands and man-made impoundments.

\section{Semipalmated Sandpiper (Calidris pusillus)}

Status: Regular migrant. 
Migration: Common to locally abundant migrant in the Western Upland and Central Plain, rare and local in the Northern Highland. Spring migrants arrive about 5 May, reaching peak abundance 15-30 May. Departure occurs 5-10 June (latest-13 June 1965 and 17 June 1977, St. Croix County). Fall migrants arrive about 20 July. Peak abundance occurs 10-20 August and departure by 5 October (latest-16 October 1964; Kemper 1965).

Habitat: Primarily a species of flooded agricultural fields, exposed edges of wetlands, man-made impoundments, and sandbars associated with islands in the St. Croix River.

\section{Western Sandpiper (Calidris mauri)}

Status: Casual migrant.

Records: There are spring records from St. Croix County including 2-4 May 1975 (peak of 11 on 3 May), 13 May 1976, 25 May 1963, 31 May 1965, and 2 June 1966. There are five fall records including three in St. Croix County; 2 August 1977, 14 August 1975, and 19 August 1974. At Crex Meadows, Burnett County, one western sandpiper was observed on 15 and 21 August 1955 , and on 12 October 1974.

Habitat: The St. Croix County observations included birds associated with the exposed edge of a semipermanently flooded wetland. The Burnett County record was obtained from the exposed edge of a man-made impoundment.

\section{Least Sandpiper (Calidris minutilla)}

Status: Regular migrant.

Migration: Common spring and fairly common fall migrant in the Western Upland and Central Plain, rare and local in the Northern Highland. Spring migrants arrive about 30 April (earliest-23 April 1959, Burnett County). Peak abundance occurs 5-15 May and departure by 25 May. Fall migrants arrive 5-10 July (earliest-25 June 1972, Chisago County). Peak abundance occurs 25 July to 10 August and departure by 30 September.

Habitat: Primarily a species of flooded agricultural fields, exposed edges of wetlands, and sandbars associated with St. Croix River islands.

\section{White-rumped Sandpiper (Calidris fuscicollis)}

Status: Regular migrant.

Migration: Fairly common spring migrant in the Western Upland, uncommon to rare elsewhere. Uncommon to rare throughout the Valley in fall. Spring migrants arrive about 10 May (earliest-20 April 1974, St. Croix County). Peak abundance occurs 20 May to 5 June and departure by 15 June. Fall migrants arrive about 20 July and depart by 15 September (latest-6 October 1964, Kemper 1965). Peak fall populations cannot be determined because of few records. 
Habitat: Primarily a species of flooded agricultural fields and muddy edges of seasonally flooded wetlands.

\section{Baird's Sandpiper (Calidris bairdii)}

Status: Regular migrant.

Migration: Rare spring and uncommon fall migrant in the Western Upland, rare to absent elsewhere. Spring migrants arrive about 5 May (earliest20 April 1974, St. Croix County) and depart by 5 June. Fall migrants return 15-20 August and depart by 15 September.

Habitat: Primarily a species of temporarily flooded agricultural fields and edges of seasonally flooded wetlands.

\section{Pectoral Sandpiper (Calidris melanotos)}

Status: Regular migrant.

Migration: Common to locally abundant spring and common fall migrant in the Western Upland and Central Plain, uncommon in the Northern Highland. Spring migrants arrive about 15 April (earliest-4 April 1964 and 1976, St. Croix County) and peak abundance occurs 5-10 May. During this period, flocks of up to 150 individuals are commonly observed. Spring migrants depart by 1 June. Fall migrants return about 10 July, and peak abundance is 15 August to 1 September. Small flocks are observed in early October and departure occurs by 30 October (latest-15 November 1964, Burnett County; Kemper 1965).

Habitat: Pectoral sandpipers use a variety of wetland habitats including temporarily flooded, Northern Sedge Meadow, Shrub Carr, exposed muddy edges of seasonally flooded wetlands and man-made impoundments, and St. Croix River islands.

\section{Dunlin (Calidris alpina)}

Status: Regular migrant.

Migration: Uncommon migrant throughout the Valley. Spring migrants arrive about 5 May, reaching peak abundance 15-20 May. Departure occurs 1-5 June. Fall migrants arrive about 20 August and have departed by 10 October (latest-28 October 1960, St. Croix County).

Habitat: Primarily a species of temporarily and seasonally flooded wetlands, man-made impoundments, and St. Croix River islands.

\section{Stilt Sandpiper (Micropalama himantopus)}

Status: Regular migrant.

Migration: Rare spring and uncommon fall migrant in the Western Upland, rare to absent elsewhere. Spring migrants arrive about 5 May (earliest-- 
19 April 1975, St. Croix County). Peak abundance occurs 15-20 May and departure by 25 May. Fall migrants arrive 25 July to 1 August and depart by 25 September.

Habitat: Primarily a species of seasonally flooded wetlands, muddy edges of man-made impoundments, and St. Croix River islands.

\section{Buff-breasted Sandpiper (Tryngites subruficollis)}

Status: Casual migrant.

Records: There are five records from central St. Croix County: 10 May 1974, 31 July 1967, 11 August 1975, 1 September 1968, and 9 September 1975.

Habitat: All St. Croix County records were obtained from the edge of a semipermanently flooded wetland in Sec. 11, T. 29 N., R. $18 \mathrm{~W}$.

\section{FAMILY STERCORARIIDAE: Jaegers}

\section{Parasitic Jaeger (Stercorarius parasiticus)}

Status: Accidental, two records.

Record: One adult was observed and photographed on 28 and 29 August 1957, on Phantom Lake at the Crex Meadows Wildlife Area, Burnett County (Lound and Lound 1958a). D. D. Tessen observed an adult at Crex Meadows on 28 May 1978 (Tessen $1979 a$ ).

\section{FAMILY LARIDAE: Gulls and Terns}

\section{Herring Gull (Larus argentatus)}

Status: Regular migrant and casual summer resident.

Migration: Common migrant throughout the inland areas, locally abundant along the St. Croix River. Spring migrants return in late February and reach peak abundance 25 March to 20 April. Most have departed by 15 May (latest-25 May 1969, Washington County). Fall migrants arrive during the last 2 weeks of September. Peak abundance occurs 15 October to 1 November and birds depart by 15 December.

Summer: A casual summer resident along the lower St. Croix River. Herring gulls summered in Washington County in 1968 and were observed in Washington County from 14 to 19 July 1975 (Eckert 1976).

Winter: A casual early winter resident in the lower St. Croix River Valley. On 1 January 1972 and 1 January 1975, two herring gulls were observed along the St. Croix River near Hudson (Afton CBC).

Habitat: Largely restricted to larger water bodies, including permanent lakes and the St. Croix River. 


\section{Ring-billed Gull (Larus delawarensis)}

Status: Regular migrant.

Migration: Abundant spring and fall migrant throughout the Valley. Spring migrants return 10-20 March. Peak abundance occurs between 15 April and 1 May and departure by 20 May. Fall migrants arrive in early September (earliest-24 August 1961, Burnett County). Peak abundance occurs between 15 September and 1 October. Flocks totaling 200 individuals are common during this period, and flocks of 500 are regularly observed. Fall migrants depart by 10 November (latest-17 November 1965, St. Croix County and 26 November 1976, Washington County).

Habitat: Ring-billed gulls use a variety of wetland types during migration including semipermanently and permanently flooded wetlands, large lakes, and the St. Croix River. During fall migration, ring-billed gulls make extensive use of recently plowed agricultural fields.

\section{Franklin's Gull (Larus pipixcan)}

Status: Regular migrant.

Migration: Rare migrant in the Western Upland and at Crex Meadows, Burnett County; absent from the forested regions. Spring migrants arrive between 25 April and 1 May (earliest-13 April 1954, Burnett County) and departure occurs by 25 May. Fall migrants arrive 20-25 September. Peak abundance occurs 1-20 October and departure by 10 November. During peak fall migration, Franklin's gulls are commonly found in association with ring-billed gulls on freshly plowed agricultural fields in western St. Croix County. Flocks of 200 to 300 are not uncommon and during the mid-1960's, S. D. Robbins occasionally found flocks of 1,500 Franklin's gulls in midOctober. Migrants follow a rather narrow migration path through the Western Upland; the major route is associated with the area of Prairie Wetlands. Franklin's gull is virtually absent east of R. 17 W. in St. Croix and Polk counties.

Habitat: Largely restricted to semipermanently and permanently flooded wetlands. Extensive use is made of agricultural fields during fall migration.

\section{Bonaparte's Gull (Larus philadelphia)}

Status: Regular migrant.

Migration: Uncommon migrant throughout the Valley, fairly common on the prairie wetlands of St. Croix and Washington counties. Spring migrants return between 25 April and 1 May (earliest-12 April 1971, Washington County). Peak abundance occurs 10-15 May and departure by 25 May. Fall migrants arrive about 10 September. Peak abundance occurs 20 September to 1 October and birds depart by 25 October. During the fall, Bonaparte's gulls are most commonly found along the St. Croix River, becoming rare to absent elsewhere. 
Habitat: Primarily a species of large semipermanently and permanently flooded wetlands, and open expanses of the St. Croix River.

\section{Ivory Gull (Pagophila eburnea)}

Status: Hypothetical.

Record: N. R. Stone observed three adults at the Crex Meadows Wildlife Area, Burnett County, on 3 April 1959 (Stone 1959b).

\section{Sabine's Gull (Xema sabini)}

Status: Hypothetical.

Record: A single immature was observed on 1 October 1944 along the St. Croix River at Stillwater, Washington County (Longley 1947).

\section{Common Tern (Sterna hirundo)}

Status: Regular migrant and casual summer resident.

Migration: Fairly common migrant near the St. Croix River, uncommon to rare elsewhere in the Western Upland and Central Plain, and rare to absent in the Northern Highland. Spring migrants arrive 20-25 April. Peak spring abundance occurs 10-20 May and departure by 30 May. Fall migrants return 25 August to 5 September and depart by 25 September.

Nesting Season Distribution: A casual summer resident in St. Croix and Washington counties; most summering birds are found along the St. Croix River. Establishment of nesting common terns along the lower St. Croix is seemingly possible, because a small group of common terns summer near the confluence of the Minnesota and Mississippi rivers at Ft. Snelling in the Twin Cities. Excessive recreational use of exposed beaches and sandy islands in the lower St. Croix is probably a major factor limiting colony establishment. If colonies are established at a future date, intensive restriction of human use will be necessar y.

Habitat: Primarily a species of large permanently flooded wetlands and sandy beaches and islands of the St. Croix River.

\section{Least Tern (Sterna albifrons)}

Status: Accidental, one record.

Record: R. A. Knuth observed an adult on Phantom Lake, Crex Meadows Wildlife Area, Burnett County, on 17 August 1971 (Roberts and Roberts 1972). This bird was observed by over 60 people during a Wisconsin Society for Ornithology field trip. 


\section{Forster's Tern (Sterna forsteri)}

Status: Regular migrant and casual summer resident. The WDNR listed this species as endangered (Les 1979).

Migration: Fairly common spring and rare fall migrant in the Western Upland and Central Plain, casual in the Northern Highland. Spring migrants arrive 20-25 April and are most commonly observed 5-15 May. Departure of spring migrants occurs by 25 May. Fall migrants arrive between 1-5 September and depart by 1 October.

Summer: A casual summer resident in St. Croix and Washington counties. The presence of summering birds suggests nesting; however, no nests or young have been recorded. This tern occurs with greatest frequency during the summer on the wetlands in St. Croix and Washington counties.

Habitat: Migrants are observed in association with large semipermanently and permanently flooded wetlands. Observations of summering birds have been restricted primarily to permanently flooded wetlands that support extensive growths of cattail and hardstem bulrush along the periphery of the basin.

\section{Caspian Tern (Sterna caspia)}

Status: Regular migrant.

Migration: Rare migrant in the Western Upland, casual or absent elsewhere. Spring migrants arrive about 1 May (earliest-8 April 1961, Burnett County). Peak abundance occurs 10-20 May and departure by 25 May (latest-30 May 1924, Chisago County; Roberts 1938: 2 June 1974, Washington County; Eckert 1975). Fall migrants arrive about 1 September and have departed by 25 September. During both migration periods, Caspian terns are most regularly observed on the St. Croix River. Away from the river, they are less common and more irregular in occurrence.

Habitat: Largely restricted to open expanses of the St. Croix River and large permanently flooded wetlands.

\section{Black Tern (Chlidonias niger)}

Status: Regular migrant and nesting species.

Migration: Fairly common migrant in the Western Upland and Central Plain; uncommon in the Northern Highland. Spring migrants arrive 25 April to 1 May, reaching peak abundance about 15 May. Fall migrants reach peak numbers about 10 August and have departed by 1 September (latest4 October 1965, Washington County).

Nesting Season Distribution: A fairly common nesting species in the prairie wetland region of St. Croix, Washington, and southern Polk counties, becoming less common in the forested regions. Breeding populations of the black tern have declined sharply in Wisconsin. During 1966-75, Robbins (1977) noted a $14 \%$ annual decrease in the statewide breeding population. A 
census of breeding black terns in St. Croix County showed a decrease from 42 pairs in 1975 to 9 pairs in 1977 (Faanes 1979).

Habitat: Black terns are a characteristic species of large seasonally and semipermanently flooded wetlands that support an abundance of emergent aquatic vegetation. Most nests that I have examined were on a floating vegetation mat, usually composed of submerged plants and emergent plant leaves. In the northern forested regions, black terns are less common as a nesting species. In this region, large, acidic wetlands are most regularly used for nesting.

\section{FAMILY COLUMBIDAE: Pigeons and Doves}

\section{Rock Dove (Columba livia)}

Status: Regular permanent resident.

Distribution: An abundant permanent resident in cities, towns, and near farm buildings. Uncommon to rare away from human habitation.

\section{Mourning Dove (Zenaida macroura)}

Status: Regular migrant, nesting species, and winter resident.

Migration: Abundant migrant in the Western Upland and Central Plain, uncommon and more local in the Northern Highland. Spring migrants arrive in mid-March, reaching peak abundance 5-15 April. Fall migration begins with flock formation among immatures in mid-August. Peak abundance occurs between 15 September and 1 October, and most birds depart by 25 October. Several nestlings that $I$ banded in this region were recovered in southern Texas by the end of September during the same year of banding.

Nesting Season Distribution: The mourning dove is an abundant nesting species in the Western Upland and Central Plain. In the Northern Highland, mourning doves are uncommon to rare nesting birds. Mourning doves have a rather long nesting season at this latitude; nest dates range from 18 April to 20 September.

Winter: A fairly common winter resident in the Western Upland, rare to absent elsewhere. The CBC data indicate that the early winter distribution is centered in St. Croix and Washington counties.

Habitat: A characteristic edge species, occurring in largest densities in Pine Plantations, shelterbelts, and fencerows. Occurs fairly commonly in ornamental coniferous trees planted in residential areas.

\section{Passenger Pigeon (Ectopistes migratorius)}

Status: Extinct.

Records: The destruction of this species across North America has been well documented. Passenger pigeons were a common nesting species in the 
Valley until the 1880 's. Schorger (1955) described their distribution and cited the last record at New Richmond, St. Croix County, on 28 September 1887. Roberts (1932) mentioned a "pigeon nesting" that was located between White Bear Lake and Taylors Falls in the late 1800's. This location may have been in either Chisago or Washington county.

FAMILY CUCULIDAE: Cuckoos and Anis

\section{Yellow-billed Cuckoo (Coccyzus americanus)}

Status: Regular migrant and nesting species.

Migration: Uncommon migrant in the Western Upland, rare elsewhere. Spring migrants begin to arrive between 15 and $20 \mathrm{May}$, and become well distributed over the breeding range by 5 June. There is a general exodus of fall migrants 15 August to 10 September, and the last birds depart by 20 September.

Nesting Season Distribution: An uncommon nesting species in Pierce, St. Croix, and Washington counties. Occasional summer records exist for northern Polk and southern Burnett counties. Roberts (1932) mentioned summer records for Pine County and observed that in northern areas this species "seems to vary considerably in numbers, both as to locality and season."

Habitat: A characteristic species of brushy margins, woodlot openings, brushy fencerows, and field edges. Most breeding season adults that I observed were associated with medium-aged stands of Southern Deciduous Forest; red oak and Hill's oak were the predominant vegetation type.

\section{Black-billed Cuckoo (Coccyzus erythropthalmus)}

Status: Regular migrant and nesting species.

Migration: Uncommon spring and fall migrant throughout the Valley. Spring migrants arrive in the Western Upland between 5 and $10 \mathrm{May}$, becoming most numerous during the last 2 weeks of May. Night migrants are frequently heard during the first week of June (S. D. Robbins, personal communication). Arrival in the Northern Highland occurs 15-20 May. Peak fall abundance occurs between 1 and 10 September and departure by 25 September.

Nesting Season Distribution: A fairly common nesting species throughout the Valley, although more common in the Central Plain and Northern Highland. Roberts (1938) reported that "a dozen" black-billed cuckoo nests were found during June 1926 in Chisago County.

Habitat: Brushy margins of mature Northern Deciduous Forest, Deciduous Clear Cuts, and mixed coniferous-deciduous forest.

\section{Groove-billed Ani (Crotophaga sulcirostris)}

Status: Accidental, one record. 
Record: One adult was shot in Woodbury Township, Washington County, on 20 October 1968 (Litkey 1969). The specimen was deposited in the museum collection at the University of Wisconsin-River Falls.

\section{FAMILY STRIGIDAE: Typical Owls}

\section{Screech Owl (Otus asio)}

Status: Regular permanent resident.

Distribution: Uncommon permanent resident in the Western Upland and Central Plain, rare to absent elsewhere. Bernard (1967) did not report this species in Douglas County. Green and Janssen (1975) reported that screech owls are resident in Carlton County, indicating possible residence in Pine County. Documented nesting records exist for Pierce, St. Croix, and Washington counties.

Habitat: Breeding screech owls are restricted primarily to mature deciduous forests. Most breeding pairs that I have encountered were associated with Lowland Deciduous Forest that was dominated by cottonwood, American elm, and green ash. In agricultural areas, breeding screech owls are associated with oak woodlots and they are regularly observed using ornamental tree plantings in residential areas.

\section{Great Horned Owl (Bubo virginianus)}

Status: Regular permanent resident.

Distribution: Common permanent resident throughout the Central Plain and Northern Highland, fairly common (locally common) in the Western Upland. Jackson (1942) reported great horned owls were generally distributed in northwestern Wisconsin.

Habitat: Nesting great horned owls use a variety of habitats, including Lowland Deciduous Forest, mature Northern Hardwood Forest, oak woodlots, Pine Plantations, Lowland Coniferous Forest, and Southern Deciduous Forest.

\section{Long-eared Owl (Asio otus)}

Status: Regular migrant and nesting species, casual winter resident.

Migration: Rare spring and fall migrant throughout the region. Spring migrants arrive 1-15 March and are most commonly seen 20 March to 15 April. Fall migrants arrive about 1 October and most have departed by 1 December.

Nesting Season Distribution: Rare nesting species throughout the Valley. Nesting has been reported in Washington County (Christenson and Fuller 1975). In St. Croix County, the first nest record was obtained near Hudson in 1973, and this pair also produced young in 1974. In Polk County, nesting 
long-eared owls were found in the McKenzie Creek Wildlife Area (T. 37 N., R. 16 W.) and the Sterling Pine Barrens (T. 36 N., R. 20 W.) during 1972-74. In Burnett County, nests have been found in jack pine habitat west of Grantsburg. Although breeding records are lacking for other counties in the Valley, nesting is expected in suitable habitat.

Winter: Rare winter resident in the Western Upland, casual north of this area.

Habitat: Nesting long-eared owls are usually associated with pine forests and Pine Plantations. The St. Croix County pair was found in a small valley of Southern Deciduous Forest. Wintering long-eared owls are usually associated with Pine Plantations and young pine forests.

\section{Short-eared Owl (Asio flammeus)}

Status: Regular migrant, casual summer and rare winter resident, one nest record.

Migration: Rare migrant throughout the Valley. Spring migrants arrive about 15 March and are most commonly observed 15-30 April. Most have departed by 10 May. Fall migrants arrive about 25 September. Peak numbers occur 30 October to 1 December and most depart by 15 December.

Nesting Season Distribution: C. R. Elliott observed a short-eared owl nest with three young in St. Croix County on 15 June 1978. This nest was located in a Managed Grassland on the Oakridge Waterfowl Production Area near New Richmond (Sec. 17, T. 31 N., R 17 W.). This represents the only known nest record for the Valley. The presence of additional midsummer records from Crex Meadows, Burnett County (1968-74), Polk County (1974), and St. Croix County (1976) suggest that this species nests sparingly throughout the Valley in suitable habitat. There are no known summer records for the Minnesota counties.

Winter: Rare winter resident in St. Croix, Washington, and Burnett counties. Although most records are from the CBC, two mid-January records exist for Crex Meadows.

Habitat: All breeding season records of this species have been made from Northern Sedge Meadow and retired grassland habitats. Wintering shorteared owls occur in sedge meadows and grassy fields.

\section{Snowy Owl (Nyctea scandiaca)}

Status: Regular migrant and winter resident.

Migration: Rare spring and fall migrant throughout the Valley. Yearly abundance varies considerably and migrating and wintering populations appear to be regulated by a 4-year cycle of small mammal populations on this species' tundra breeding areas. Fall migrants arrive in mid-November (earliest-14 October 1918, Pine County; 2 November 1963, Crex Meadows) and during "invasion" years, reach peak abundance 15 December to 1 January. 
Spring migration begins in late February and departure occurs by 1 April (latest-9 April 1967, Crex Meadows and 18 April 1974, St. Croix County).

Winter: Rare and local winter resident throughout the Valley. During years of peak abundance, snowy owls are fairly common winter residents at Crex Meadows, Burnett County; occasional concentrations range from six to eight birds.

Habitat: Wintering snowy owls regularly use open agricultural fields and Northern Sedge Meadow or Shrub Carr. Occasionally found associated with semipermanently flooded wetlands in the Western Upland and Central Plain. At Crex Meadows, extensive use is made of restored tall grass prairie and Northern Sedge Meadow.

\section{Barred Owl (Strix varia)}

Status: Regular permanent resident.

Distribution: Fairly common (locally common) in the Central Plain and Northern Highland, common in the Western Upland. There is apparently little difference in status between nesting and winter seasons.

Habitat: Characteristic species of mature Northern Hardwood Forest in the Central Plain and Northern Highland. Predominant vegetation of barred owl habitat includes basswood, sugar maple, trembling aspen, green ash, and white pine. Lowland Coniferous Forest that contains mature yellow birch and black spruce provides important breeding habitat in the Northern Highland. In the Western Upland, the barred owl is characteristic of mature Lowland Deciduous Forest and reaches greatest densities in large expanses of this vegetation type associated with major streams that are tributary to the St. Croix River.

\section{Great Gray Owl (Strix nebulosa)}

Status: Casual winter resident, one nest record.

Records: One was found dead near Lake Elmo, Washington County, on 15 February 1969 (Green 1969). Another individual was observed at the Northwoods Audubon Center, Pine County, on 27 January 1973. D. G. Follen (personal communication) reported a single great gray owl several times in "early November" 1979, $16 \mathrm{~km}$ east of Moose Junction, Douglas County (T. 44 N., R. 13 W.). Follen also reported a great gray owl during November 1979 in extreme northwestern Washburn County, Wisconsin, near the Douglas and Burnett County border.

Nesting Season Distribution: Follen (1979) provided the only evidence of great gray owl nesting in the Valley. On 18 August 1978, he observed two immature great gray owls $0.6 \mathrm{~km}$ north of Moose Junction, Douglas County (Sec. 7, T. 44 N., R. 14 W.). The estimated age of these birds was 6-8 weeks. During the observation, an adult was seen and hear' nearby. On 19 August 1978 , three immatures and one adult were observed at the same location and a stick nest found. 
Habitat: Vegetation adjacent to the Douglas County nest was Lowland Coniferous Forest dominated by black spruce, white birch, and green ash. Vast areas of similar habitat exist in southwestern Douglas and adjacent Pine counties. Continued observations in this region may reveal additional breeding records.

\section{Hawk Owl (Surnia ulula)}

Status: Casual winter resident.

Records: Bernard and Klugow (1963) provided the most evidence of hawk owl occurrence in the Valley. They reported three observations of hawk owls in Douglas County including "one bird $5.6 \mathrm{~km}$ north of Dairyland (T. 44 N., R. 14 W.), in early March 1963." On 17 March 1963, a dead hawk owl was found $16 \mathrm{~km}$ west of Solon Springs (T. 45 N., R. 13 W.) and on 20 March 1963 another hawk owl (possibly the first individual) was observed $8.8 \mathrm{~km}$ northeast of Dairyland. Other records include one bird collected at Stacy, Chisago County, on 20 October 1962, and two birds observed in Pine County on 17 February 1963 (Green 1963).

These observations were made during a winter that produced an "invasion" of hawk owls in northwestern Wisconsin and much of northern Minnesota. Later that same year, the nests and young of two separate pairs were found in northeastern Douglas County. The hawk owl is included as casual rather than accidental, because the species is well known for occasional irruptions into southern areas during the winter (cf. Green 1963; Eckert 1978). Because large expanses of excellent hawk owl habitat (Lowland Coniferous Forest) occur in southern Douglas and adjacent Pine counties, I would expect additional records of this owl during future "invasions."

\section{Boreal Owl (Aegolius funereus)}

Status: Casual winter resident.

Records: There are two records for Burnett County: 19 December 1952 at Crex Meadows (N. R. Stone), and 13 April 1975 near the Fish Lake Wildlife Area (W. Norling). In Pine County, one was observed on 9 November 1972.

\section{Saw-whet Owl (Aegolius acadicus)}

Status: Regular migrant and winter resident.

Migration: Rare migrant throughout the Valley. Spring migrants arrive in mid-March, and most observations occur between 25 March and 15 April (latest-16 May 1961, St. Croix County). Fall migrants arrive in mid-September and most have departed by 15 December. This species is one of the least common regular owls in the Valley. At Hawk Ridge near Duluth, Minnesota, saw-whet owls are the most common migrant owl (Evans 1975). No doubt their small size, nocturnal habits, and very secretive behavior contribute to the scarcity of records. 
On 24 May 1978, C. A. Kemper and S. D. Robbins heard saw-whet owls calling in four separate locations about $15 \mathrm{~km}$ west of Solon Springs, Douglas County. S. D. Robbins (personal communication) suggests that the saw-whet owl probably nests in the upper Valley.

Winter: Apparently a casual winter resident until mid-January. Several late December records exist from the Afton, St. Paul Suburban (Washington County) and New Richmond (St. Croix County) CBC. Also, there are several January records from Burnett County. The recent increased interest in "owling" with tape-recorded calls may help to better establish the winter status of this species.

Habitat: Most records of wintering saw-whet owls have been from mediumaged Pine Plantations and mature pine forests.

\section{FAMILY CAMPRIMULGIDAE: Goatsuckers}

\section{Whip-poor-will (Camprimulgus vociferus)}

Status: Regular migrant and nesting species.

Migration: Fairly common migrant throughout the Western Upland and Central Plain, locally common in the Northern Highland. Most records are of birds on breeding territory, rather than actual migrants. Spring migrants arrive 1-5 May and are widely distributed by 10-20 May. Jackson (1942) reported that whip-poor-wills were common at Danbury, Douglas County, during late May 1918. The status of this species in the fall is poorly understood. Whip-poor-wills are quiet during this period and they are almost never reported. Most observations have been made between 20 August and 20 September (latest-22 October 1964, Burnett County).

Nesting Season Distribution: Fairly common and local nesting species throughout the Central Plain and Northern Highland, uncommon and local in the Western Upland.

Habitat: In the Western Upland, nesting whip-poor-wills are found associated with mixed stands of xeric deciduous and coniferous woods, and in Pine Plantations. In the Central Plain and Northern Highland this species is most common in medium-aged Northern Hardwood Forest, Jack Pine Barren, and Pine Plantations.

\section{Common Nighthawk (Chordeiles minor)}

Status: Regular migrant and nesting species.

Migration: Common spring and locally abundant fall migrant throughout the Valley. Spring migrants arrive 5-10 May and peak abundance occurs 25 May to 5 June. Fall migration begins with flock formation in early August. Peak abundance occurs between 15 August and 1 September and departure by 20 September (latest-7 October 1973 and 8 October 1965 , Washington County). 
Nesting Season Distribution: A common nesting species in cities and towns, less common and more localized in areas away from human habitation.

Habitat: This species has adapted well to expanding human population. In cities and towns, an abundance of flat roofs and gravel roadways provide excellent breeding habitat. Although nesting habitat away from human habitation is poorly known, most birds are found associated with mixed deciduous-coniferous forest with sandy soils and open (or barren) understory.

\section{FAMILY APODIDAE: Swifts}

\section{Chimney Swift (Chaetura pelagica)}

Status: Regular migrant and nesting species.

Migration: Chimney swifts are common to locally abundant in the Western Upland and Central Plain, fairly common in the Northern Highland. Because of their relationship with human settlements, this species is most frequently observed near villages and cities. Spring migrants begin to arrive about 30 April and peak abundance occurs 10-20 May. Fall migrants begin to form loose flocks during late July. Peak fall migration occurs between 25 August and 10 September and departure by 20 September (latest5 October 1947).

Nesting Season Distribution: Breeding chimney swifts have been recorded in all counties of the Valley. Largest breeding populations occur in the Western Upland and Central Plain, where human habitation provides an abundance of nesting sites. Jackson (1942) reported that chimney swifts occurred regularly in the northern regions, even in areas removed from human settlement.

Habitat: Chimney swifts are most numerous in villages and cities where they nest in chimneys and abandoned buildings. Populations of breeding chimney swifts occur in the forested regions where they occupy hollow trees (Jackson 1942) and other natural cavities for nesting.

\section{FAMILY TROCHILIDAE: Hummingbirds}

\section{Ruby-throated Hummingbird (Archilochus colubris)}

Status: Regular migrant and nesting species.

Migration: Fairly common migrant throughout the Valley. Spring migrants arrive during the second week of May (earliest-13 April 1953, Burnett County) and peak abundance occurs 20 May to 1 June. Peak fall abundance occurs 10-25 August and departure by 20 September (latest-1 October 1947, St. Croix County; Robbins 1948a).

Nesting Season Distribution: The ruby-throated hummingbird is a fairly common nesting species throughout the Valley; positive or inferred breeding 
has been recorded in all counties.

Habitat: Breeding ruby-throated hummingbirds occur in a variety of habitat types, most commonly in brushy margins, openings of deciduous forests, and Deciduous Clear Cuts in the Central Plain and Northern Highland. I have found several hummingbird nests in the branches of cottonwoods along the Willow River in St. Croix County. Jackson (1942) noted that in northwestern Wisconsin this species seemed to prefer tamarack bogs for nesting. He speculated that the abundant Usnea moss that grows on tamarack was important for nest building.

\section{Rufous Hummingbird (Selasphorus rufus)}

Status: Accidental, one record.

Record: One rufous hummingbird was observed in Washington County, about $3.2 \mathrm{~km}$ west of Prescott, Wisconsin, from the end of September to 15 October 1978 (Binder 1979). This was one of three rufous hummingbirds that occurred in Minnesota during the late summer and fall 1978.

\section{FAMILY ALCEDINIDAE: Kingfishers}

\section{Belted Kingfisher (Megaceryle alcyon)}

Status: Regular migrant, nesting species, and winter resident.

Migration: Common migrant throughout the Valley. Apparent increases in populations begin about 1 April and peak abundance occurs 10-25 April. Peak fall migration occurs 10 September to 1 October and most depart by 10 November.

Nesting Season Distribution: The belted kingfisher is a fairly common nesting species throughout the Valley. Probably most abundant in the Central Plain and Northern Highland where there is an abundance of lakes, rivers, and streams.

Winter: An uncommon early winter resident north to Burnett and Pine counties; rare after mid-January. Belted kingfishers are uncommon throughout the winter in Washington, St. Croix, and Pierce counties, where fast-moving streams provide ample open water for fishing.

Habitat: Usually found near permanent lakes and streams that support fish populations. Nests are usually in steep banks adjacent to streams. One nest observed in western St. Croix County was in the bank of a sandstone outcropping about $2 \mathrm{~km}$ from the nearest water.

\section{FAMILY PICIDAE: Woodpeckers}

\section{Common Flicker (Colaptes auratus)}

Status: Regular migrant, nesting species, and winter resident. 
Table 3. Mean number of woodpeckers, flycatchers, and swallows recorded on western Wisconsin Breeding Bird Survey transects, 1966-78.

\begin{tabular}{|c|c|c|c|c|c|}
\hline \multirow[b]{2}{*}{ Species group } & \multirow{2}{*}{$\begin{array}{c}\text { Western } \\
\text { Upland } \\
\text { Hudson }\end{array}$} & \multicolumn{2}{|c|}{ Central Plain } & \multicolumn{2}{|c|}{ Northern Highland } \\
\hline & & Dresser & Loraine & Union & Minong \\
\hline \multicolumn{6}{|l|}{ Woodpeckers } \\
\hline Common flicker & 7.1 & 5.8 & 7.6 & 1.9 & 3.2 \\
\hline Pileated woodpecker & 0.0 & 0.3 & 1.4 & 0.8 & 0.5 \\
\hline Red-bellied woodpecker & 0.0 & 0.6 & 1.1 & 0.0 & 0.0 \\
\hline Red-headed woodpecker & 3.4 & 3.5 & 3.8 & 0.5 & 0.0 \\
\hline Yellow-bellied sapsucker & 0.0 & 0.0 & 1.4 & $<0.1$ & 1.1 \\
\hline Hairy woodpecker & 1.2 & 0.6 & 1.8 & 1.2 & 1.0 \\
\hline Downy woodpecker & 1.2 & 0.9 & 3.3 & 1.8 & 1.8 \\
\hline \multicolumn{6}{|l|}{ Flycatchers } \\
\hline Eastern kingbird & 5.0 & 4.9 & 5.1 & 4.7 & 5.0 \\
\hline Great crested flycatcher & 6.4 & 7.2 & 13.1 & 19.9 & 11.0 \\
\hline Eastern phoebe & 1.2 & 0.8 & 2.4 & 2.0 & 2.8 \\
\hline Yellow-bellied flycatcher & 0.0 & 0.0 & 0.0 & 0.0 & 0.1 \\
\hline Willow flycatcher & $<0.1$ & 0.0 & 0.4 & 0.0 & 0.0 \\
\hline Alder flycatcher & 0.0 & 0.4 & 1.2 & 0.0 & 4.8 \\
\hline Least flycatcher & $<0.1$ & 0.7 & 5.4 & 6.0 & 12.7 \\
\hline Eastern wood pewee & 1.9 & 2.0 & 6.1 & 15.4 & 8.5 \\
\hline \multicolumn{6}{|l|}{ Swallows } \\
\hline Tree swallow & 2.4 & 4.5 & 8.4 & 4.7 & 13.0 \\
\hline Bank swallow & 13.8 & 3.9 & 6.7 & 0.0 & 0.0 \\
\hline Rough-winged swallow & 2.7 & 3.4 & 3.3 & 0.0 & 0.1 \\
\hline Barn swallow & 17.3 & 18.5 & 18.2 & 1.2 & 3.4 \\
\hline Cliff swallow & 3.4 & 4.8 & 11.5 & 0.0 & 8.1 \\
\hline Purple martin & 4.7 & 25.3 & 11.5 & 3.2 & 6.0 \\
\hline
\end{tabular}

Migration: Common to locally abundant migrant throughout the Valley. Noticeable spring movements are observed by 15-25 March. Spring migrants usually travel in small scattered groups; consequently, few large concentrations are observed. Fall migration begins in late August with dispersal of young from the nesting areas. Peak fall migration occurs 15 September to 10 October and most depart by 1 November. During peak movements in fall migration, groups of 40-50 individuals are common, with groups totaling 100 occasionally observed.

Nesting Season Distribution: Breeding Bird Survey data show that the common flicker is the most common and well-distributed breeding woodpecker in the Valley (Table 3). Goddard (1972) found the common flicker the most abundant breeding woodpecker in the Kinnickinnic River Valley, Pierce County. Nesting has been observed in all counties in the Valley.

Winter: Common flickers are rare and local winter residents in the Western Upland and rare or absent in other regions (Table 4). Wintering individuals are occasionally recorded as far north as Burnett and Pine counties. 
Table 4. Relative abundance of various birds on St. Croix River Valley Christmas Bird Counts. Values presented are the mean number of birds per party hour.

\begin{tabular}{|c|c|c|c|c|c|}
\hline \multirow[b]{2}{*}{ Species groups } & \multicolumn{3}{|c|}{ Western Upland } & \multicolumn{2}{|c|}{ Northern Highland } \\
\hline & Afton & $\begin{array}{l}\text { Suburban } \\
\text { St. Paul }\end{array}$ & $\begin{array}{c}\text { New } \\
\text { Richmond }\end{array}$ & $\begin{array}{l}\text { Grants- } \\
\text { burg }\end{array}$ & $\begin{array}{c}\text { Solon } \\
\text { Springs }\end{array}$ \\
\hline \multicolumn{6}{|l|}{ Woodpeckers } \\
\hline Common flicker & $<0.1$ & $<0.1$ & $<0.1$ & $<0.1$ & 0.0 \\
\hline Pileated woodpecker & 0.2 & $<0.1$ & $<0.1$ & $<0.1$ & $<0.1$ \\
\hline Red-bellied woodpecker & 0.6 & 0.2 & 0.2 & $<0.1$ & 0.0 \\
\hline Red-headed woodpecker & $<0.1$ & $<0.1$ & $<0.1$ & $<0.1$ & 0.0 \\
\hline Hairy woodpecker & 1.2 & 0.5 & 0.3 & 0.3 & 0.3 \\
\hline Downy woodpecker & 1.8 & 0.8 & 0.6 & 0.4 & 0.2 \\
\hline $\begin{array}{l}\text { Black-backed three-toed } \\
\text { woodpecker }\end{array}$ & 0.0 & 0.0 & 0.0 & 0.0 & $<0.1$ \\
\hline \multicolumn{6}{|l|}{ Corvids } \\
\hline Blue jay & 6.8 & 3.1 & 5.8 & 3.7 & 2.7 \\
\hline Common raven & 0.0 & 0.0 & 0.0 & 0.1 & 4.8 \\
\hline Common crow & 12.2 & 3.6 & 8.1 & 2.5 & 0.8 \\
\hline \multicolumn{6}{|l|}{ Parids and nuthatches } \\
\hline Black-capped chickadee & 8.0 & 4.2 & 2.8 & 2.1 & 2.7 \\
\hline Tufted titmouse & 0.2 & $<0.1$ & 0.0 & 0.0 & 0.0 \\
\hline White-breasted nuthatch & 2.8 & 1.7 & 1.0 & 0.7 & 0.3 \\
\hline Red-breasted nuthatch & 0.1 & $<0.1$ & 0.0 & $<0.1$ & 0.3 \\
\hline \multicolumn{6}{|l|}{$\begin{array}{l}\text { Selected finches and } \\
\text { sparrows }\end{array}$} \\
\hline Cardinal & 3.1 & 0.7 & 0.8 & 0.1 & 0.0 \\
\hline Evening grosbeak & 0.5 & 0.3 & 0.8 & 8.3 & 3.3 \\
\hline Purple finch & 2.2 & 0.4 & 0.2 & $<0.1$ & $<0.1$ \\
\hline Pine grosbeak & 0.2 & 0.1 & 0.0 & 0.2 & 4.6 \\
\hline Common redpoll & 4.5 & 7.6 & 6.7 & 6.8 & 16.7 \\
\hline Pine siskin & 4.0 & 0.9 & 0.5 & 0.7 & 0.3 \\
\hline American goldfinch & 4.1 & 2.7 & 3.1 & 2.3 & 0.2 \\
\hline Dark-eyed junco & 8.9 & 3.2 & 2.5 & 0.2 & $<0.1$ \\
\hline Tree sparrow & 6.9 & 2.0 & 4.9 & 0.3 & 0.0 \\
\hline
\end{tabular}

Habitat: Common flickers are characteristic of the Southern Deciduous Forest, reaching greatest densities in medium-aged oak forest. Fairly common breeding species in Northern Hardwood Forest and Pine Barrens. Uncommon to rare in other habitat types.

Pileated Woodpecker (Dryocopus pileatus)

Status: Regular permanent resident. 
Distribution: Uncommon to fairly common resident in all regions of the Valley; most numerous along the St. Croix River and its major tributaries. Because of large breeding territories and relative scarcity, low numbers of this woodpecker are recorded along BBS transects (Table 3). All five survey routes traverse fair to good habitat, yet this woodpecker is recorded in very low numbers.

Winter: Winter distribution of this woodpecker is presented in Table 4. Largest winter populations occur in the Western Upland. The pileated woodpecker is fairly regular during winter in Burnett, Douglas, and Pine counties where a combination of Northern Hardwood Forest and coniferous forest provides optimum habitat.

Habitat: The pileated woodpecker is characteristic of large expanses of the mature Lowland Deciduous Forest along and adjacent to the St. Croix River. Fairly common in mature Upland Hardwood Forest and Lowland Coniferous Forest. Uncommon to rare in Southern Deciduous Forest. Rare to absent in other habitat types.

\section{Red-bellied Woodpecker (Melanerpes carolinus)}

Status: Regular permanent resident.

Distribution: Fairly common breeding bird in the Western Upland, uncommon to rare in the Central Plain, and rare to absent in the Northern Highland. The red-bellied woodpecker is a southern species that reaches its northern range limit along the St. Croix River (Peterson 1951).

Breeding Bird Survey data show that red-bellied woodpeckers occur regularly in central Polk County. Occasional birds with young are observed in Burnett and southern Pine counties. Hamerstrom and Hamerstrom (1963) include two confirmed nest records from along the St. Croix River in western Burnett County. Movement into the northern regions must be fairly recent since Jackson (1942) failed to record this species in 1919 during his work in northwestern Wisconsin. Bernard (1967) considered this species to be very rare in Douglas County, citing three observations in areas north of the St. Croix River. Green and Janssen (1975) cited documented breeding records for Washington County and showed red-bellied woodpecker breeding range extending north to the Chisago-Pine county line.

Winter: Locally a fairly common winter resident in the Western Upland, rare and local adjacent to the St. Croix River in the Central Plain (CBC; Table 4).

Habitat: This woodpecker is a characteristic species of Lowland Deciduous Forest. Large expanses of lowland forest occurring along the St. Croix River and its major tributaries provide excellent breeding habitat. During the breeding season, pairs also use the edge between lowland forest and Southern Deciduous Forest and locally in Northern Hardwood Forest. Wintering birds are found primarily in Lowland Deciduous Forest and Southern Deciduous Forest. This woodpecker is attracted to corncribs on farms near woodland edges during the winter. 


\section{Red-headed Woodpecker (Melanerpes erythrocephalus)}

Status: Regular migrant, nesting species, and winter resident.

Migration: Fairly common spring and fall migrant in the Western Upland and Central Plain. Uncommon and more sporadic in the Northern Highland. The first noticeable influx of spring migrants occurs 20 April to $1 \mathrm{May}$, reaching peak numbers 15-25 May. Fall migration begins about 10 August in the Northern Highland and 20 August elsewhere. Peak movements occur 20 August to 15 September and most have departed by 1 November.

Nesting Season Distribution: Fairly common breeding species in the Western Upland and Central Plain, rare to uncommon in the Northern Highland. Breeding Bird Survey Data indicate that a uniformly distributed breeding population occurs through the Western Upland and Central Plain (Table 3). Evidence of nesting or the presence of inferred nesting records have been obtained in all counties of the Valley.

Winter: Uncommon and local winter resident in upland oak habitat near the St. Croix River. The CBC data (Table 4) indicate that red-headed woodpeckers occur regularly north to Burnett and Pine counties in winter. Moe (1968) also showed that the winter distribution of red-headed woodpeckers in Wisconsin extended northward including southeastern Burnett County.

Habitat: Breeding red-headed woodpeckers occupy both upland and lowland deciduous forests. Largest breeding densities occur in mature Southern Deciduous Forest in the Western Upland. This woodpecker also uses second growth oak forest and open-oak forest extensively. Mature Lowland Deciduous Forest that is dominated by green ash and American elm is also an important breeding habitat. Suitable breeding habitat is enhanced by the presence of dead or dying trees. The spread of oak-wilt and dutch elm disease has aided in providing additional nesting sites for these birds.

\section{Yellow-bellied Sapsucker (Sphyrapicus varius)}

Status: Regular migrant and nesting species, casual in winter.

Migration: Uncommon spring and fall migrant in all regions. Spring migrants begin to arrive 25 March to 5 April and peak migration occurs 15 April to 1 May. Fall migration begins 15-25 August. Peak numbers occur 20 September to 5 October and departure by 25 October.

Nesting Season Distribution: Uncommon to fairly common breeding bird in the Northern Highland, uncommon in the Central Plain, rare and local in the Western Upland. Documented nesting records exist for all counties in the Valley.

Winter: Yellow-bellied sapsuckers have been observed twice on the Afton CBC, Washington County: 2 January 1960 and 1 January 1970 (at a feeding station).

Habitat: Yellow-bellied sapsuckers occupy a variety of upland deciduous and coniferous forest types for nesting. This species is most common during the breeding season in climax or near climax Northern Hardwood Forest 
that is dominated by maple and basswood. Nesting also occurs in mature and second growth aspen-maple forest. Coniferous forests are used to a lesser extent for nesting. Breeding yellow-bellied sapsuckers regularly use extensive stands of Lowland Deciduous Forest in the Western Upland.

\section{Hairy Woodpecker (Picoides villosus)}

Status: Regular permanent resident.

Distribution: Fairly common breeding bird in the Northern Highland and Central Plain, uncommon and local in the Northern Highland. Goddard (1972) reported a breeding density of 3.45 pairs per 40 ha in the Kinnickinnic River Valley, Pierce County. Breeding Bird Survey data (Table 3) suggest that breeding densities are fairly uniform throughout the Valley.

Winter: Fairly common winter resident in the Western Upland and Central Plain; uncommon in the Northern Upland. The CBC data (Table 4) show the greatest densities occurring along and adjacent to the lower St. Croix River. The largest count was 91 on the Afton CBC, 1 January 1972.

Habitat: Hairy woodpeckers are not indicative of any one habitat type. Breeding pairs occupy a variety of habitats including Lowland Deciduous Forest, Southern Deciduous Forest, Northern Hardwood Forest, and Lowland Coniferous Forest.

\section{Downy Woodpecker (Picoides pubescens)}

Status: Regular permanent resident.

Distribution: Fairly common in the Western Upland, common in the Central Plain and Northern Highland. Breeding Bird Survey data (Table 3) suggest that the breeding population increases slowly northward across the Valley. Jackson (1942), however, noted that the downy woodpecker was usually less numerous than the hairy woodpecker in northern Wisconsin. Goddard (1972) reported a breeding density of 6.6 pairs per 40 ha in the Kinnickinnic River Valley, Pierce County.

Winter: Common winter resident in the Western Upland, fairly common in the Central Plain and Northern Highland. The mean ratio of downy to hairy woodpeckers in the Valley during winter is 1.5 to 1.0. Only in the Northern Highland does the hairy woodpecker appear to be more numerous than the downy woodpecker. Young (1961) also noted a greater proportion of hairy woodpeckers to downy woodpeckers in northwestern Wisconsin. Largest winter counts were 143 on the Afton CBC, 1 January 1972 and 123 on the Suburban St. Paul CBC, 2 January 1976.

Habitat: Habitat use by the downy woodpecker is characterized by both upland and lowland coniferous and deciduous forests. Edge situations are used more extensively by this species than by the hairy woodpecker, especially for feeding. During winter, downy woodpeckers occupy habitat similar to that used for breeding. In agricultural areas, downy woodpeckers also use corn stubble fields regularly for feeding. 


\section{Black-backed Three-toed Woodpecker (Picoides arcticus)}

Status: Regular migrant, nesting species, and winter resident.

Migration and Winter: Casual fall migrant and winter resident in all regions. Dates for Washington County include 28 October 1964 at Stillwater (Honetschlager 1965), 2 November 1972, and 14 January 1973 (Huber 1974b). This woodpecker was observed once in Chisago County on 13 November 1966 , and in Pine County on 28 February 1974 (Eckert 1974). Wisconsin records include Polk County, 23 December 1974 at the McKenzie Creek Wildlife Area (T. 37 N., R. 16 W.); Thiel (1978) lists three winter records for Polk County, although he provides no dates or locations. Douglas County records include one bird $9.6 \mathrm{~km}$ west of Solon Springs (Sec. 36, T. 45 N., R. 15 W.) on 26 November 1974. One was observed on the Solon Springs CBC on $23 \mathrm{De}-$ cember 1976 (Table 4).

Nesting Season Distribution: Rare and local permanent resident of the Northern Highland. Bernard (1967) considered this woodpecker a "rare permanent resident that nests locally" in Douglas County. The nesting areas that Bernard refers to occur along the Brule River. The only evidence of nesting in the Valley is provided by Knudson (1978). On 3 August 1978, Knudson observed three black-backed three-toed woodpeckers that he considered to be one female and two immatures in T. 43 N., R. 13 W., Douglas County. On 21 or 22 August 1978, Jeffery Knudson observed a male at the same location. Knudson speculated that this was a nesting record.

Habitat: The habitat associated with most black-backed three-toed woodpeckers observed during the breeding season is predominantly Lowland Coniferous Forest. Coniferous trees killed by fire are particularly attractive to this species. Although Knudson (1978) found adult and immature birds using Jack Pine Barrens, this habitat may have been used only as feeding habitat and not for nesting. This species is found in the extensive Lowland Coniferous Forest of Burnett, Douglas, and Pine counties. Additional field work in Lowland Coniferous Forest directly adjacent to the St. Croix River may shed more light on the breeding status of this species.

\section{Northern Three-toed Woodpecker (Picoides tridactylus)}

Status: Casual winter visitor.

Records: The first bird was observed by K. H. Dueholm on 8 March 1975 in Polk County, and subsequently on 15 March 1975 (Faanes 1975). This bird was using a small Black Spruce-Tamarack Bog (Sec. 12, T. 34 N., R. 16 W.). B. Klugow (personal communication) observed a second northern three-toed woodpecker in Polk County (Sec. 3, T. 33 N., R. 15 W.) on 11 April 1976.

\section{FAMILY TYRANNIDAE: Tyrant Flycatchers}

\section{Eastern Kingbird (Tyrannus tyrannus)}

Status: Regular migrant and nesting species. 
Migration: Common migrant throughout the Valley. Spring migrants return to the Western Upland 30 April to 5 May and reach the Northern Highland by 10 May (earliest-11 April 1954, Crex Meadows, Burnett County). Peak spring migration occurs 10-25 May and most birds are on nesting territories by 1 June. Fall migration begins in early August. Peak fall populations occur 20 August to 1 September and departure by 15 September (latest2 October 1969, Chisago County).

Nesting Season Distribution: Common breeding species in all regions. Confirmed breeding records exist only for Pierce, Polk, and St. Croix counties. Inferred nesting exists for the remaining counties. Breeding Bird Survey data (Table 3) indicate that an unusually uniform and well-distributed breeding population exists within the Valley.

Habitat: Eastern kingbirds use edge habitats probably more than any other flycatcher. Characteristics of typical eastern kingbird breeding habitat include woodlots, scattered clumps of tall shrubs, fencelines, open fields, and edges of sedge meadows. Fences and transmission lines are apparently important components of breeding habitat and are used extensively as hunting perches. Jackson (1942) found eastern kingbirds "especially abundant" in Jack Pine Barrens and regrown burned areas in northwestern Wisconsin.

\section{Western Kingbird (Tyrannus verticalis)}

Status: Casual migrant and nesting species.

Migration: Rare spring and fall migrant. Records are too few to determine average dates of arrival or departure. However, most observations occur 15 May to 1 September. Migrants have been recorded from Burnett, St. Croix, and Washington counties.

Nesting Season Distribution: Rare nesting species in St. Croix County. Nesting was first reported in 1961 when a pair was successful at Hudson. A pair returned to the same site each year until 1971 when small boys shot the pair from the nest. During the summer of 1967, Peter Tweet found an additional breeding pair near Burkhardt, in west central St. Croix County. Additional breeding season records include a single bird at Crex Meadows, Burnett County, on 27 July 1953, 11 and 26 July, and 5 August 1956. In Minnesota, two young were observed at Langdon, Washington County, on 13 August 1952 (Lupient 1952). In St. Croix County, western kingbirds were not recorded again until I observed a group of four near New Richmond on 16 August 1975. This group remained in the same area until 25 August. The next record was obtained on 19 August 1976, when a single bird was found in the same area. This individual remained in the area until 26 August 1976.

Habitat: The Hudson breeding pair was located in a residential area. Other records of breeding pairs are associated with edge habitats in agricultural areas.

\section{Great Crested Flycatcher (Myiarchus crinitus)}

Status: Regular migrant and nesting species. 
Migration: Uncommon to fairly common migrant throughout the Valley, locally common along the lower reaches of the St. Croix River. Spring migrants generally arrive about 1 May in the Western Upland and 5-10 May in the Northern Highland. Peak abundance occurs 15-30 May. Fall migration begins in mid-August, reaching peak abundance by 1 September. Migrants have departed the Northern Highland by 15 September and the remainder of the region by 25 September.

Nesting Season Distribution: Uncommon nesting species in the Western Upland and Central Plain, fairly common to locally common in the Northern Highland. Breeding Bird Survey data (Table 3) suggest a gradual increase in breeding densities moving northward through the Valley. However, Jackson (1942) recorded great crested flycatchers as "never more than two seen at a locality ..." in the Northern Highland. Goddard (1972) found this flycatcher to be among the 12 most numerous breeding birds along the Kinnickinnic River Valley in Pierce County. Nesting has been confirmed only in St. Croix County where I observed a nest along the Willow River on 10 June 1975 . Although only one nest has been confirmed, inferred nesting records have been obtained in the remaining counties.

Habitat: The great crested flycatcher is a forest species, generally assocaited with the upper canopy of medium-aged to mature deciduous forest. The only confirmed nesting record was obtained from a mature Lowland Deciduous Forest where cottonwood was the predominant tree species. Pairs are commonly recorded in extensive stands of Northern Hardwood Forest and in Southern Deciduous Forest. Use of residential habitats has also been recorded.

\section{Eastern Phoebe (Sayornis phoebe)}

Status: Regular migrant and nesting species.

Migration: Fairly common migrant throughout the Valley. Eastern phoebes are among the first passerines to return in the spring; the first migrants arrive in the Western Upland 20-25 March. Although most observations consist of pairs on breeding territories, a peak in spring migration is apparent 15-25 April. Fall migration begins in mid-August and peak movements occur 5-15 September. Late departure dates range from 1-5 October in the Northern Highland to 20 October in the Western Upland.

Nesting Season Distribution: Fairly common nesting species in all regions and documented nesting records exist from each county. Breeding Bird Survey data (Table 3) indicate a fairly evenly distributed breeding population. Jackson (1942) considered the eastern phoebe to be a very common breeding bird along the St. Croix River. Goddard (1972) reported a density of 9.1 breeding pairs per 40 ha in the Kinnickinnic River Valley, Pierce County.

Habitat: Eastern phoebes are attracted to a variety of edge situations, primarily woods-field border and streamside habitats. During the nesting season, eastern phoebes are usually associated with bridges, culverts, or other man-made structures, sheer cliffs, and rocky outcroppings. 


\section{Yellow-bellied Flycatcher (Empidonax flaviventris)}

Status: Regular migrant, one nesting record.

Migration: Uncommon spring migrant in the Western Upland and Central Plain, locally common in the Northern Highland. Fairly common to locally common fall migrant in all regions. Earliest spring migrants arrive 10-15 May, reaching the Northern Highland about 20 May. Peak migration occurs 20-30 May and departure from most areas by 5 June. Fall migration begins by mid-August (earliest--31 July 1967, Washington County). Peak movements occur 15 August to 1 September and birds depart by 15 September.

Nesting Season Distribution: Bernard (1967) cited the only known nesting record for the region, a nest with four eggs near Wascott (Douglas County) on 21 July 1941. Green and Janssen (1975) cited the observation of singing males near Bruno, Pine County. I observed singing males along the St. Croix River near Gordon, Douglas County, on 20 July 1976, and again on 10 June 1977. In neither instance were nests observed. The yellow-bellied flycatcher is probably more widespread as a nesting species than available records indicate because of the vast amount of suitable nesting habitat in the Northern Highland.

Habitat: The 1976 and 1977 records were obtained from an extensive stand of black spruce-tamarack swamp adjacent to the St. Croix River. At other seasons, this flycatcher regularly uses a variety of edge situations.

\section{Acadian Flycatcher (Empidonax virescens)}

Status: Casual migrant and possible nesting species.

Records: Observations of this bird at the northern limit of its range have been sporadic. Because of their occurrence during normal nesting periods, this species must be considered a possible nesting bird. St. Croix County records include 12 May 1974 at Roberts, and 15 May 1973, 21 June to 5 July 1963 , and 22 July 1965 at Hudson. One record exists of this species in the Minnesota Counties. Bratlie (1976) described observations at Franconia, Chisago County, on 8 and 16 June 1976.

Habitat: A species of deciduous forest habitats including Lowland Deciduous Forest and heavily wooded hillsides in mesic Southern Deciduous Forest.

\section{Willow Flycatcher (Empidonax traillii)}

The decision of the American Ornithologists' Union (AOU 1973) to split the Traill's flycatcher (Empidonax traillii) into two separate species created many problems in range delineation. Before that time, both willow and alder flycatchers were recorded as one species, even though song and habitat differences were readily apparent. Fortunately, S. D. Robbins maintained separate records of both species based on song, and from his work it is possible to 
draw conclusions on the range of these two species in Wisconsin (Robbins $1974 b$ ). Because this work was not carried out in Minnesota, only generalized distribution can be provided for that State.

Status: Regular nesting species.

Migration: Most records of this species are of breeding pairs on territory. Consequently, dates of first occurrence are nearly impossible to determine. The earliest record I have of a singing willow flycatcher is 20 May 1974 in St. Croix County. This date is near the usual range of 10-20 May for the arrival of most Empidonax flycatchers in the Valley. Fall departure probably begins in early August and most birds have left by 15 September. Because nearly all Empidonax flycatchers are silent in the fall, few data exist on their migration.

Nesting Season Distribution: Robbins (1974b) cited summer records of this species in St. Croix County in 1961-67 and 1970. There are Polk County records in 1965-67 and 1970 and Pierce County records for 1965-78. S. D. Robbins (personal communication) found a singing male willow flycatcher near Fish Lake, Burnett County, on 17 June 1978 and 22 June 1977. I observed male willow flycatchers on territory in Washington County near Stillwater on 6 July 1978. Breeding Bird Survey data were not separable to species until 1975. Consequently, only recent survey data from the Loraine transect in Polk County provide information on relative abundance (Table 3). One nesting record exists for the region. I found a nest with four eggs along Black Brook, Cylon Township, St. Croix County, on 9 July 1978.

Habitat: Willow thickets and Shrub Carr associations are the primary habitats of this bird. The St. Croix County nest was placed in a young black willow located in an extensive Shrub Carr. Observations of singing males are invariably associated with these wetland types.

\section{Alder Flycatcher (Empidonax alnorum)}

Status: Regular migrant and nesting species.

Migration: Observations of alder flycatchers during spring are usually pairs on presumed breeding territories. Song dates of first observation usually occur 15-20 May in the Western Upland and about 20 May in the Northern Highland. Alder flycatchers are apparently most numerous 20 May to 5 June. Fall migration begins in mid-August, reaching peak numbers 1-10 September. Departure of this species occurs 15-20 September.

Nesting Season Distribution: Fairly common to locally common nesting species north of the Tension Zone. Within this zone of overlap, observations of breeding pairs have been made in southern Washington and northwestern Pierce counties. Breeding Bird Survey data (Table 3) indicate that the largest breeding populations occur north of the Tension Zone. Documented nesting records exist for Polk and Douglas counties. Faanes and Goddard (1976) cited observations of singing males 15-20 June in northern St. Croix County.

Habitat: Alder flycatchers use a greater diversity of habitat types than is 
used by the preceding species. Nests in Polk County were in Alder Thicket habitat where speckled alder was the predominant shrub species. Elsewhere, breeding pairs have been recorded in Northern Hardwood Forest, Black Spruce-Tamarack Bogs, and Deciduous Clear Cuts.

\section{Least Flycatcher (Empidonax minimus)}

Status: Regular migrant and nesting species.

Migration: Common to locally abundant migrant in all regions, reaching largest numbers in the Central Plain and Northern Highland. Spring migrants arrive in the Western Upland 1-5 May and the Northern Highland by 10 May. Peak abundance occurs 15 May in the Western Upland to $20 \mathrm{May}$ in the north. Fall migration begins in early August. Peak fall migration occurs 20 August to 1 September in the north and 25 August to 5 September elsewhere. Departure from the Northern Highland occurs 10-15 September and elsewhere by 30 September (latest -5 October 1974, St. Croix County).

Nesting Season Distribution: Common to locally abundant nesting species in all regions. Goddard (1972) reported a breeding density of 8.1 pairs per 40 ha in the Kinnickinnic River Valley, Pierce County. Confirmed nesting records exist only for Polk County; inferred nesting has been documented in all other counties. Breeding Bird Survey data (Table 3) indicate that least flycatcher breeding populations apparently increase in abundance moving northward through the Valley, reaching peak density in the Northern Highland. Jackson (1942) reported that the least flycatcher was the most abundant flycatcher in Polk and Burnett counties.

Habitat: Primarily an edge species; nesting season least flycatchers are usually recorded in a variety of habitat types. Western Upland breeding birds are usually associated with medium-aged Southern Deciduous Forest and mature Lowland Deciduous Forest. Central Plain and Northern Highland birds are typically recorded in mature Northern Hardwood Forest, Deciduous Clear Cut, and mixed coniferous-deciduous forest. In the Jack Pine Barren regions of the Central Plain, breeding pairs are usually associated with deciduous habitats along streams rather than jack pines.

\section{Eastern Wood Pewee (Contopus virens)}

Status: Regular migrant and nesting species.

Migration: Eastern wood pewees are among the latest arriving flycatchers in this region, usually not observed until after 15 May learliest-26 April 1974, Burnett County), and peak migration occurs 20-30 May. Fall migration begins about 5 August in the Northern Highland and 15 August elsewhere. Peak migration occurs 20 August to 1 September and departure by 25 September (latest-27 September 1976, Washington County).

Nesting Season Distribution: Fairly common nesting species in all regions of the Valley. Confirmed nesting has been documented in St. Croix and 
Douglas counties with inferred nesting elsewhere. Breeding Bird Survey data (Table 3) indicate that a fairly uniform breeding population occurs in the Western Upland and Central Plain. Relative abundance increases markedly north of that zone. Goddard (1972) found this species to be the sixth most abundant breeding bird along the Kinnickinnic River in Pierce County. The mean breeding density in that area was 27.4 pairs per 40 ha.

Habitat: The eastern wood pewee is characteristic of mature deciduous forest. In the Western Upland, breeding pairs are generally associated with mature Lowland Deciduous Forest and occasionally with mature Southern Deciduous Forest. Central Plain and Northern Highland populations are apparently most numerous in mature Northern Hardwood Forest.

\section{Olive-sided Flycatcher (Nuttallornis borealis)}

Status: Regular migrant and nesting species.

Migration: The olive-sided flycatcher is among the latest arriving songbirds. Average date of spring arrivals in the Western Upland is $16 \mathrm{May}$ and arrivals in the Northern Highland are during 20-25 May. Dates of peak abundance are not provided, primarily because this bird migrates singly or in small groups. Consequently, very few individuals are recorded daily during periods when they would be expected to be numerous. Migrants have usually departed nonbreeding areas by 1 June (latest-11 June 1974, Pierce County). Fall migrants arrive in the Western Upland during early August and become most conspicuous 20-30 August. Departure from northern nesting areas occurs about 5 September and departure elsewhere by 20 September.

Nesting Season Distribution: The only confirmed evidence of nesting is provided by Green and Janssen (1975) who listed a nest record from Sturgeon Lake, Pine County. Considerable inferred breeding evidence exists for northern Burnett and southern Douglas counties where this bird is an uncommon and local summer resident. Although nests have not been observed, extensive stands of black spruce-tamarack habitat along the St. Croix River in Burnett, Douglas, and Pine counties usually support breeding season adults.

Habitat: Olive-sided flycatchers are characteristic of boreal forest habitat during the nesting season. Extensive stands of Lowland Coniferous Forest, combined with an interspersion of open areas of sphagnum moss provide ideal breeding habitat. Also frequently used are white cedar swamps. One factor that characterizes olive-sided flycatcher habitat is the presence of dead snags that are used for feeding and singing perches.

\section{FAMILY ALAUDIDAE: Larks}

\section{Horned Lark (Eremophila alpestris)}

Status: Regular migrant and nesting species, casual winter resident. 
Migration: Common to abundant migrant throughout the Valley. The largest numbers occur in open agricultural regions of the Western Upland and Central Plain. Spring migration begins during late January in the south and the first migrants reach Burnett and Pine counties by 15 February. Peak spring migration occurs between 25 February and 25 March. Peak fall migration occurs between 15 October and 10 November and most have departed by 15 December.

Nesting Season Distribution: Horned larks are common nesting birds in the Western Upland and Central Plain, rare and local in the Northern Highland.

Winter: During the winter, horned larks present a perplexing problem in determining whether individuals are early or late migrants or actual winter residents. North of St. Croix Falls, this species is generally absent from midDecember to late January. South of St. Croix Falls, occasional small flocks of 5 to 20 individuals can be found in open areas during this period. I usually consider displaying individuals to be returning summer residents and consider migration to be commencing with the observation of the first large flocks.

Habitat: Horned larks are characteristic of agricultural areas. Breeding densities appear largest in short vegetation associated with domestic hayfields and oat stubble. This species has adapted well to man's increased agricultural production and breeding pairs regularly use bare cultivated fields and various row-crop fields.

\section{FAMILY HIRUNDINIDAE: Swallows}

\section{Tree Swallow (Iridoprocne bicolor)}

Status: Regular migrant and nesting species.

Migration: Abundant migrant in all regions. Spring migrants arrive in the Western Upland 25 March to 5 April and reach the Northern Highland 5-10 April. Peak spring abundance occurs 20-30 April. Fall migration begins in late July with flocking of family groups. Peak fall abundance occurs 15-30 August and departure by 10 October. During peak fall migration, tree swallows are occasionally observed in massive mixed-species flocks near large water bodies. Concentrations of 4,000 to 5,000 individuals are frequently observed along the lower St. Croix River.

Nesting Season Distribution: Common nesting species in the Western Upland and Central Plain, common and more local in the Northern Highland. Breeding Bird Survey data (Table 3) show that tree swallows are uniformly distributed throughout the Valley.

Habitat: Tree swallows nest in loose, semicolonial associations. Breeding pairs are typically associated with water bodies that are normally near small groves of trees (Western Upland and Central Plain) or along northern Forest Bordered Lakes. Extensive use is made of the edge between deciduous forest and natural openings or agricultural fields. Nests are normally located in natural cavities in tree stumps or fence posts and occasionally in holes in 
stream banks. Tree swallows have benefited by exploiting the large number of eastern bluebird houses that have been placed in agricultural areas and near residential areas.

\section{Bank Swallow (Riparia riparia)}

Status: Regular migrant and nesting species.

Migration: Common spring and fall migrant throughout the Valley. Spring migrants arrive in the Western Upland 15-20 April and reach the Northern Highland 20-25 April. Peak abundance occurs between 25 April and 15 May. Fall migration begins during mid-July. Peak abundance through the Valley occurs between 25 July and 5 August, and departure by 5 September.

Nesting Season Distribution: Common nesting species throughout the Western Upland and Central Plain becoming uncommon to rare and local in the Northern Highland. Breeding Bird Survey data (Table 3) show that the breeding distribution of this swallow is restricted primarily to areas that are not heavily forested.

Habitat: Breeding bank swallows are associated with natural banks along rivers, streams, and lakes. Gravel pits and roadside banks that were exposed during highway construction are also heavily used. Colonies are frequently associated with open agricultural areas that are used extensively for foraging.

\section{Rough-winged Swallow (Stelgidopteryx ruficollis)}

Status: Regular migrant and nesting species.

Migration: Common migrant in the Western Upland and Central Plain, north to Grantsburg, Burnett County; rare and local elsewhere. Spring migrants arrive 15-25 April and peak abundance occurs 25 April to 5 May. Fall migration begins in late July with gathering of family groups. Peak abundance occurs between 25 July and 10 August and departure by 1 September.

Nesting Season Distribution: Fairly common (locally abundant) breeding species in the Western Upland and Central Plain, rare to absent in heavily forested regions. Breeding Bird Survey data suggest that this species is the least common of the swallows nesting in the Valley. However, Goddard (1972) found rough-winged swallows among the 10 most abundant breeding bird species along the Kinnickinnic River, Pierce County. Average breeding density in that area was 26.5 pairs per 40 ha. This exceptionally high density results from the numerous exposed limestone cliffs along that river, which provide abundant nesting sites.

Habitat: Breeding rough-winged swallows are usually associated with exposed banks along rivers and streams. Particularly important are limestone cliffs along fast-moving streams and rivers in the Western Upland. Occasional use is made of artificial earthen banks and bridges over small streams. 


\section{Barn Swallow (Hirundo rustica)}

Status: Regular migrant and nesting species.

Migration: Common spring and fall migrant throughout the Valley. Spring migrants arrive in the Western Upland during 15-20 April reaching the Northern Highland about 25 April (earliest-11 April 1953, Burnett County). Peak abundance during spring migration occurs 5-10 May. Fall migration begins about 1 August. Peak fall abundance occurs 25 August to 10 September and departure by $10-15$ October.

Nesting Season Distribution: Common nesting species in the Western Upland and Central Plain, uncommon and local in the Northern Highland. Breeding Bird Survey data (Table 3) suggest that the barn swallow is the most numerous breeding swallow in the Western Upland and Central Plain.

Habitat: Primarily a species of open habitats, usually associated with human habitation. Most nests are found under bridges or on buildings.

\section{Cliff Swallow (Petrochelidon pyrrhonota)}

Status: Regular migrant and nesting species.

Migration: Common migrant throughout the Valley, occasionally abundant near the St. Croix River. Spring migrants arrive in the Western Upland 1-5 May and peak abundance occurs 10-20 May. Fall migration begins in mid-August. Peak fall abundance occurs 1-10 September and departure by 25 September (latest-18 October 1974, Pierce County).

Nesting Season Distribution: Fairly common breeding species throughout the Valley. Breeding Bird Survey data (Table 3) suggest that the abundance of the nesting population increases northward across the Valley.

Habitat: Primarily a colonial or semicolonial nesting species, utilizing barns, sheds, and bridges extensively for nest placement. Occasional groups are found nesting in natural settings, including limestone cliffs.

\section{Purple Martin (Progne subis)}

Status: Regular migrant and nesting species.

Migration: Common to abundant migrant throughout the Valley. Spring migrants arrive 5-10 April and peak abundance occurs 1-10 May. Fall migration begins about 1 August. Peak abundance occurs 25 August to 1 September and departure by 20 September (latest-6 October 1966, Washington County).

Nesting Season Distribution: Common nesting species throughout the Valley. Jackson (1942) referred to the purple martin as "the most generally distributed" among the swallows in northwestern Wisconsin. Breeding Bird Survey data (Table 3) suggest that the largest densities occur in the Central Plain.

Habitat: The purple martin is one of few species benefiting from expanding 
human population. Colonial martin houses in residential and rural areas have become vitally important to this species.

FAMILY CORVIDAE: Jays, Magpies, and Crows

\section{Gray Jay (Perisoreus canadensis)}

Status: Casual migrant, winter and summer resident.

Migration: Irregular migrant throughout the Valley. Earliest fall migration records include 17 October 1976 (Washington County), 25 October 1965 (Crex Meadows, Burnett County), and 1 November 1974 (Chisago County). Most fall observations occur 15 November to 15 December. Green (1967) described an invasion of gray jays in northern Minnesota that resulted in several Valley records. Spring observations range from 23 February 1957 to 30 March 1966 and 6 April 1954 (Crex Meadows, Burnett County).

Nesting Season Distribution: W. Norling observed one pair of gray jays in a spruce forest southwest of Moose Junction, Douglas County, on 3 July 1978. On 27 June 1956, A. C. Sprunt observed several gray jays in the Kohler-Peet Wildlife Area, Burnett County (Lound and Lound 1956b). Sprunt found this species near Gordon, Douglas County, on 6 July 1956.

Winter: Irregular winter visitor with documented records only from Burnett (1948, 1955, 1957, and 1976), Pierce (January 2, 1976) and Pine (1973 and 1976) counties. During the winter of $1956-57$, gray jays were reported as "numerous" near Grantsburg, Burnett County. This species is probably more common during winter months than available data indicate, particularly in the Northern Highland.

Habitat: During migration and winter, gray jays use a variety of habitats including Lowland Coniferous Forest, Northern Hardwood Forest, and Jack Pine Barren. Summer observations have been restricted to extensive areas of Lowland Coniferous Forest.

\section{Blue Jay (Cyanocitta cristata)}

Status: Regular migrant, nesting species, and winter resident.

Migration: Common to locally abundant migrant in all regions. The first migration movements in spring are usually noted about 1-5 April and peak numbers occur 25 April to 10 May. Fall migration begins in mid-August with the formation of loose flocks. Peak movements during fall occur 5-15 September and most migrants have departed the Northern Highland by 15 November.

Nesting Season Distribution: Fairly common breeding species in the Western Upland and Central Plain, common in the Northern Highland. Goddard (1972) found the blue jay to be among the 10 most common breeding birds in mixed deciduous habitat along the Kinnickinnic River, Pierce County. Mean breeding density in that area was 23 pairs per 40 ha. Breeding 
Table 5. Mean number of corvids, parids, wrens, mimids, and thrushes recorded on western Wisconsin Breeding Bird Survey transects, 1966-78.

\begin{tabular}{|c|c|c|c|c|c|}
\hline \multirow[b]{2}{*}{ Species group } & \multirow{2}{*}{$\begin{array}{l}\text { Western } \\
\text { Upland } \\
\text { Hudson }\end{array}$} & \multicolumn{2}{|c|}{ Central Plain } & \multicolumn{2}{|c|}{ Northern Highland } \\
\hline & & Dresser & Loraine & Union & Minong \\
\hline \multicolumn{6}{|l|}{ Corvids } \\
\hline Blue jay & 4.9 & 9.0 & 11.2 & 29.0 & 19.1 \\
\hline Common raven & 0.0 & 0.0 & 0.5 & $<0.1$ & 3.2 \\
\hline Common crow & 36.3 & 30.2 & 54.7 & 28.6 & 29.5 \\
\hline \multicolumn{6}{|l|}{ Parids and nuthatches } \\
\hline Black-capped chickadee & 0.4 & 0.6 & 2.4 & 7.0 & 8.2 \\
\hline White-breasted nuthatch & 0.6 & 1.8 & 2.2 & 1.0 & 0.5 \\
\hline Red-breasted nuthatch & 0.0 & $<0.1$ & 0.0 & 0.2 & 0.5 \\
\hline \multicolumn{6}{|l|}{ Wrens } \\
\hline House wren & 8.9 & 10.4 & 13.3 & 14.8 & 9.0 \\
\hline Winter wren & 0.0 & 0.0 & 0.0 & 0.0 & 0.1 \\
\hline Long-billed marsh wren & 0.0 & 0.2 & 0.2 & 0.0 & 0.0 \\
\hline Short-billed marsh wren & 2.5 & 3.7 & 6.4 & 0.0 & 1.3 \\
\hline \multicolumn{6}{|l|}{ Mimids } \\
\hline Gray catbird & 5.2 & 8.8 & 16.7 & 8.0 & 12.4 \\
\hline Brown thrasher & 8.4 & 9.1 & 5.2 & 5.9 & 5.6 \\
\hline \multicolumn{6}{|l|}{ Thrushes } \\
\hline American robin & 30.5 & 46.1 & 30.6 & 19.8 & 26.9 \\
\hline Wood thrush & 0.4 & 0.6 & 0.7 & 0.8 & 2.2 \\
\hline Hermit thrush & 0.0 & 0.0 & 0.0 & 1.4 & 6.1 \\
\hline Veery & $<0.1$ & 1.4 & 11.2 & 1.2 & 27.1 \\
\hline Eastern bluebird & 2.1 & 3.8 & 3.9 & 6.7 & 1.8 \\
\hline
\end{tabular}

Bird Survey data (Table 5) demonstrate a gradual increase in abundance northward across the Valley.

Winter: Blue jays are among the few conspicuous members of the winter avifauna in the Valley. Populations vary considerably each winter because of various environmental factors affecting habitat suitability and food supply. Analysis of CBC data (Table 4) indicates that winter populations are largest in the Western Upland region where the predominant habitat is Southern Deciduous Forest. Winter populations in Jack Pine Barrens (Grantsburg $\mathrm{CBC)}$ are also high. Lowest winter populations occur in the mixed deciduous-coniferous forest type of the Northern Highland. Largest CBC counts include 597 (2 January 1976) and 485 (2 January 1977) on the Suburban St. Paul CBC, and 509 (1 January 1970) on the Afton CBC.

Habitat: Blue jays use a variety of habitats for nesting, including deciduous and coniferous communities, edge situations, and various ornamental plantings in residential areas. Highest breeding densities occur in northern coniferous communities including Jack Pine Barren and mixed deciduous-conif- 
erous habitats. In the Western Upland, blue jays are common in Southern Deciduous Forest and in remnants of oak savannah. This species appears to be partial to oak forest. During years of poor acorn production, the migration of this species is heavy. In years of high acorn production, large wintering populations occur.

\section{Black-billed Magpie (Pica pica)}

Status: Casual, two fall records and one hypothetical record.

Records: K. H. Dueholm observed a black-billed magpie at the McKenzie Creek Wildlife Area, Polk County, on 25 October 1973. C. Strehlow observed one in St.Croix County on 12 November 1921 (Milwaukee Public Museum files). Bernard (1967) described a specimen in the University of Wisconsin-Superior bird collection that was "said to have been taken at Solon Springs in the 1930's. Unfortunately, however, no label is attached to the specimen." Roberts (1932) stated that in Minnesota, the black-billed magpie occurs "as far east as Pine and Goodhue counties, both bordering on the Wisconsin line."

\section{Common Raven (Corvus corax)}

Status: Regular permanent resident.

Migration: Uncommon spring and fall migrant in the Northern Highland and Central Plain, accidental elsewhere. Definite migratory movements begin about 15 October, reaching a peak by 1 December. Spring migration begins in late February with dispersal from winter territories. Most ravens have reached their breeding territories by 1 April.

Nesting Season Distribution: Breeding Bird Survey data suggest that the common raven is a rare breeding bird in the Central Plain and uncommon in the Northern Upland (Table 5). Documented nest records exist only for Burnett and Polk counties. Jackson (1942) failed to record ravens during his research in northwestern Wisconsin in 1919. Bernard (1967) considered common ravens uncommon in summer, but cited no evidence of breeding.

Winter: Fairly common to common winter resident in the Northern Highland, uncommon to fairly common in the Central Plain. The largest concentrations have been recorded near Solon Springs, Douglas County; 192 were recorded on 23 December 1974.

Habitat: Common ravens are not characteristic of any one habitat during the breeding season. The Burnett County nest was found in an oak savannah that was invaded by jack pine. The Polk County nest was in mixed aspenmaple forest. Observations of apparent territorial common ravens indicate an attraction to Northern Hardwood Forest during the nesting season. Large numbers of common ravens are usually associated with garbage dumps during the winter. 


\section{Common Crow (Corvus brachyrhynchos)}

Status: Regular migrant, nesting species, and winter resident.

Migration: Spring migration begins in the Western Upland during mid-February with dispersal from local winter roosts. Numbers of migrants gradually increase, reaching peak numbers $25 \mathrm{March}$ to 10 April. Fall migration begins in late August with flock formation. Peak movements occur $20 \mathrm{Sep}$ tember to 15 October and nonwintering birds have departed by 15 No. vember.

Nesting Season Distribution: Common nesting bird in all regions. Breeding Bird Survey data indicate a fairly uniform breeding population throughout the Valley; greatest abundance is in the Central Plain (Table 5). Documented breeding records exist for all eight counties.

Winter: The CBC data (Table 4) show the winter distribution pattern of the common crow. This species is common to locally abundant in the Western Upland, fairly common in the Central Plain, and rare and local in the Northern Highland. The highest winter counts include 959 (1 January 1975), 941 (1 January 1977), and 908 (1 January 1974). all on the Afton CBC.

Habitat: The common crow is primarily an edge species using several woodland habitat types. Common crow breeding habitat is further characterized by the association of agricultural fields or Old Field Community. Also used is Lowland Deciduous Forest and Northern Hardwood Forest. The occurrence of large farming operations and the resultant abundance of waste grains probably enhance the habitats of the Western Upland for wintering common crows.

\section{FAMILY PARIDAE: Titmice}

\section{Black-capped Chickadee (Parus atricapillus)}

Status: Regular permanent resident.

Distribution: Uncommon (locally common) nesting species in the Western Upland, common and more widespread in the Central Plain and Northern Highland. Analysis of BBS data (Table 5) suggests a rapid increase in abundance moving northward from the southern oak forest type of the Western Upland to the mixed deciduous-coniferous forest of the Northern Highland. Goddard (1972) reported a breeding density of 15.1 pairs per 40 ha in mixed habitats along the Kinnickinnic River, Pierce County. Jackson (1943) reported that this species was "only moderately common at most localities" in northwestern Wisconsin. However, he reported it "seemed to be more plentiful . . a at Solon Springs."

Winter: Common and well-distributed winter resident in the Western Upland and Central Plain, uncommon in the Northern Highland. Christmas Bird Count data (Table 4) also suggest that the largest winter densities occur in the southern regions. Mean numbers of black-capped chickadees on the Afton CBC (Western I!pland) are nearly three times as large as those 
on the Solon Springs CBC (Northern Highland). Comparison of CBC and BBS data (Tables 4 and 5) shows that the relative abundance of this species among physiographic regions is reversed between seasons. This is logical considering the periodic influxes of this species into areas south of the breeding range throughout the eastern United States.

Habitat: The black-capped chickadee is rather cosmopolitan in its choice of habitats during the nesting season. Breeding pairs in the Western Upland use Southern Deciduous Forest and Lowland Deciduous Forest most extensively. Habitat use in the Central Plain includes Northern Hardwood Forest, Lowland Deciduous Forest, Black Spruce-Tamarack Bog, and Jack Pine Barren. In the Northern Highland, extensive use is made of Northern Hardwood Forest, primarily stands of medium-aged mixed forest that is dominated by sugar maple, basswood, and scattered white pine. Also important in this region are Lowland Coniferous Forest, Black Spruce-Tamarack Bog, and remnant stands of Upland Coniferous Forest. One important aspect of black-capped chickadee breeding habitat is the presence of natural cavities or dead snags for nest placement. The spread of Dutch Elm disease, primarily in Lowland Deciduous Forest, may benefit this species. Several breeding pairs that I observed in this habitat in the Western Upland were using holes in dead American elm that had been excavated by woodpeckers.

\section{Boreal Chickadee (Parus hudsonicus)}

Status: Casual winter resident, one summer record.

Winter: Boreal chickadees have been recorded on several CBC's: Afton29 December 1966 and 1 January 1972; Suburban St. Paul-1 January 1975; Grantsburg-26 December 1976; and Solon Springs-23 December 1976. A single bird was recorded at St. Croix Falls (Polk County) on 3 January 1950. and one individual in Washington County on 30 September 1972.

Nesting Season Distribution: An adult was seen and heard near Solon Springs, Douglas County, on 27 June 1972. Boreal chickadees are not known to nest in northwestern Wisconsin; Bernard (1967) mentioned only winter records from Douglas County. Green and Janssen (1975) showed that the breeding range of this species in Minnesota extended south to central Carlton County.

The midsummer Douglas County record increases the probability that the boreal chickadee nests rarely in the Valley. An abundance of suitable Lowland Coniferous Forest habitat exists along the St. Croix in southern Douglas County and throughout Pine County. Additional field work in this region during the summer may provide confirmation of nesting.

Habitat: Boreal chickadees observed during the winter are usually found at feeding stations. The June 1972 observation was of a single bird in Lowland Coniferous Forest.

\section{Tufted Titmouse (Parus bicolor)}

Status: Regular permanent resident. 
Distribution: Rare and local breeding species restricted primarily to the Western Upland. Establishment of this species in the lower Valley has been very recent. Roberts (1932) rarely found this bird in southeastern Minnesota and then primarily only during the winter months. Currently, the major area of abundance appears to be along the St. Croix River and its major tributaries north to Marine-on-St. Croix (Washington County). Confirmed nest records have been obtained from St. Croix and Washington counties. Edgar (1943) observed tufted titmice feeding their young in Washington County on 25 July 1943, thus providing the first confirmed nest record for Minnesota. Occasional records from central Polk and southern Burnett counties (Bauers 1964), suggest another range extension. Young (1967) summarized the distribution of this species in Wisconsin and reported that the tufted titmouse was concentrated south of the Tension Zone in that State.

Habitat: Primarily a species of mature Lowland Deciduous Forest associated with major tributaries of the St. Croix River. Near Afton State Park (Washington County) and along the Kinnickinnic River (Pierce County), tufted titmice also use stands of medium-aged Southern Deciduous Forest.

\section{FAMILY SITTIDAE: Nuthatches}

\section{White-breasted Nuthatch (Sitta carolinensis)}

Status: Regular permanent resident.

Distribution: Fairly common permanent resident throughout the Valley, decreasing in abundance northward. Breeding Bird Survey data (Table 5) suggest that breeding white-breasted nuthatches occur in largest numbers in the Central Plain, becoming much less numerous in the heavily forested Northern Highland. Bernard (1967), however, considered this species common in Douglas County. Goddard (1972) reported a breeding season density of 14.7 pairs per 40 ha along the Kinnickinnic River, Pierce County.

Winter: Common winter resident in the Western Upland, fairly common in the Central Plain, and uncommon in the Northern Highland. Christmas Bird Count data (Table 4) show a rapid decrease in relative abundance moving northward through the Valley. Densities in birds per party hour are nearly 10 times greater on the Afton Count (Western Upland) than on the Solon Springs Count (Northern Highland).

Habitat: Primarily a species of various deciduous forest communities including Southern Deciduous Forest, Lowland Deciduous Forest, and Northern Hardwood Forest. Rarely encountered during the breeding season in pure coniferous forest. Although nests are frequently placed in coniferous trees (primarily white pine), breeding pairs are usually associated with extensive mixed deciduous-coniferous forest. Breeding pairs regularly use large deciduous trees in residential areas. Residential feeding stations are important during winter. 


\section{Red·breasted Nuthatch (Sitta canadensis)}

Status: Regular migrant, nesting species, and winter resident.

Migration: An irruptive species, usually an uncommon migrant throughout the Valley. During years of peak migration, red-breasted nuthatches are common to locally abundant, primarily in the Northern Highland and Central Plain. In years when this species stages a major population influx, the first migrants may arrive by 15 July and build gradually to a 20 September to 15 October peak. Fall migrants arrive in the Central Plain and Western Upland during late August (earliest-19 August 1970, Washington County). Peak fall abundance occurs 1 October to 15 November. Peak spring migration occurs 15 March to 15 April and most have departed nonbreeding areas by 15 May.

Nesting Season Distribution: Green and Janssen (1975) reported that nests or family groups were observed in Washington County. These authors showed that the breeding range of the red-breasted nuthatch included all three Minnesota counties. There are no known breeding records for the Wisconsin counties. Nesting season adults are rare in the Central Plain and uncommon in the Northern Highland. Breeding Bird Survey data (Table 5) suggest that this nuthatch is uncommon in southern Douglas County and throughout Pine County.

Winter: Uncommon to rare and irregular winter resident in the Western Upland, uncommon in the Central Plain, and fairly common in the Northern Highland (Table 4). The occasional winter irruptions are considered to be related to the failure of the pinecone crop in northern nesting regions. Young's (1965) analysis of winter red-breasted nuthatch distribution in Wisconsin suggests that largest densities occur north of the Tension Zone.

Habitat: During the nesting season, the red-breasted nuthatch is characteristic of Lowland Coniferous Forest that supports black spruce, tamarack, and yellow birch in the overstory. Occasional breeding pairs are also recorded in Black Spruce-Tamarack Bogs, and in Northern Hardwood Forest that exhibits a mixture of coniferous and deciduous tree species. Winter habitat use is similar to that of the nesting season in the Northern Highland and Central Plain. Wintering red-breasted nuthatches in the Western Upland make extensive use of Pine Plantations. Ornamental conifers associated with feeding stations in residential areas also receive use during the winter.

\section{FAMILY CERTHIIDAE: Creepers}

\section{Brown Creeper (Certhia familiaris)}

Status: Regular migrant, winter resident, and probable nesting species.

Migration: Fairly common migrant throughout the Valley. Spring migrants arrive in the Western Upland 10-20 March, reaching the Northern Highland about 25 March. Peak spring abundance occurs 10-20 April and departure 
by 10 May (latest-19 May 1966, Washington County). The first fall migrants arrive in the Western Upland 1-10 September. Peak fall abundance occurs 25 September to 25 October and most have departed by 20 No. vember.

Nesting Season Distribution: Uncommon and local resident, restricted primarily to the Northern Highland, although occasionally observed in the Central Plain. There is no direct evidence of nesting in the Valley. I have observed breeding season adults along the upper St. Croix River in Douglas and Pine counties in 1976 and 1977. Although I observed no nests or young, these records suggest possible nesting. Intensive field work in southern Douglas and throughout Pine counties during late May and June may shed additional light on brown creeper breeding status.

Winter: Brown creepers occur throughout the Valley during early winter; observations were made until 23 December in southern Douglas County. During midwinter this species is rare or absent in the Northern Highland and Central Plain, uncommon and local in the Western Upland.

Habitat: My observations of brown creepers during the nesting season have been confined to extensive stands of Northern Hardwood Forest that are dominated by mixed sugar maple, basswood, white birch, trembling aspen, red pine, and white pine. During the winter Lowland Deciduous Forest, dominated by silver maple, American elm, and green ash, is used exten. sively. Occasional use is also made of mixed-oak forest and Pine Plantations.

\section{FAMILY TROGLODYTIDAE: Wrens}

\section{House Wren (Troglodytes aedon)}

Status: Regular migrant and nesting species.

Migration: Common migrant throughout the Valley. Spring migrants arrive in the Western Upland 20-25 April (earliest-15 April 1978, St. Croix County) and reach the Northern Highland about 25 April. Peak spring migration occurs 1-10 May. Peak fall migration occurs 25 August to 15 September and departure by 10 October.

Nesting Season Distribution: Breeding Bird Survey data (Table 5) show that this is the most numerous wren in the Valley during the nesting season and that relative abundance is similar throughout the Valley. Jackson (1943) observed that the house wren was a common nesting species throughout northwestern Wisconsin. Goddard (1972) found that house wrens were the third most abundant breeding species in the Kinnickinnic River Valley, Pierce County. Mean density in that area was 36.1 pairs per 40 ha.

Habitat: A characteristic species of several deciduous forest communities including Southern Deciduous Forest, Old Field Community, Northern Hardwood Forest, Lowland Deciduous Forest, and Deciduous Clear Cut. Also important are edge habitats including forest-agricultural field borders, brushy road ditches, and brushy fencerows. Jackson (1943) found house wrens "especially abundant" in burns and cut-over land. This species has adapted 
well to ornamental plantings in residential areas and is a familiar "back yard" bird, responding especially well to artificial cavities.

\section{Winter Wren (Troglodytes troglodytes)}

Status: Regular migrant and nesting species, two winter records.

Migration: Uncommon migrant throughout the Valley. Spring migrants arrive in the Western Upland 30 March to 10 April, reaching the Northern Highland 10-15 April learliest-27 March 1942, Burnett County; Feeney 1942). Peak spring migration through the Valley occurs 15 April to 1 May and departure from non-nesting areas occurs by 10 May. Fall migration begins in late August and the first migrants arrive in the Western Upland 10-15 September. Peak fall abundance occurs 25 September to 15 October and departure by 1 November.

Nesting Season Distribution: Uncommon nesting species restricted primarily to the Northern Highland (Table 5). Hofslund (1952) reported a nest with four young at Solon Springs, Douglas County. Rare and casual elsewhere during the nesting season. Green and Janssen (1975) mentioned summer records but no broods from Washington County. Several recent records suggest that the winter wren is probably established as a nesting species in northeastern Chisago County. Longley (1973b) reported winter wrens along Lawrence Creek, Chisago County, on 9 June 1973, and Bratlie (1976) observed a winter wren nest at the same location on 16 June 1976.

Winter: There are two records (1 January 1968 and 1973) from the St. Croix County portion of the Afton CBC.

Habitat: The winter wren is a characteristic nesting species of Lowland Coniferous Forest dominated by black spruce, balsam fir, and yellow birch. The Chisago County nesting area was described by Longley $(1973 b)$ as a hardwood forest consisting of sugar maple, yellow birch. American elm, ash, white pine, and red pine.

\section{Bewick's Wren (Thryomanes bewickii)}

Status: Casual migrant and summer resident.

Records: S. D. Robbins observed Bewick's wrens near North Hudson, St. Croix County, on four occasions: 5-17 May 1963; 13 May 1964; 7 May 1965; and 17 June 1961. Green and Janssen (1975) mentioned that Bewick's wren had been observed during the summer in Washington County.

\section{Carolina Wren (Thyrothorus ludovicianus)}

Status: Casual migrant, nesting species, and winter visitor.

Migration Records: Roberts (1938) reported the observation of a single Carolina wren at Woodbury, Washington County, on 30 May 1935. One was observed at St. Croix Falls, Polk County (no date), during 1940 (Kumlien and 
Hollister 1951). I found one along the Kinnickinnic River, Pierce County, on 26 April 1977. S. D. Robbins found one near Roberts, St. Croix County, on 3 May 1965 (Faanes and Goddard 1976). Olyphant (1972) caught and banded a Carolina wren in Washington County on 26 October 1971. This bird remained in the area through at least 4 January 1972.

Winter: One Carolina wren was reported on the Afton CBC in Washington County on 1 January 1974 (Eckert 1974). W. Gantenbein observed single Carolina wrens at Osceola, Polk County, during December 1965 to 13 January 1966 (Hilsenhoff 1966), and December 1966 to 14 January 1967.

Nesting Season Distribution: Green and Janssen (1975) reported that Carolina wrens have nested in Washington County. In 1938, two Carolina wrens were observed at St. Croix Falls by S. Owen from 15 April to 4 September. During the summer of 1938 , several unsuccessful nest searches were made, but on 2 and 3 July the adults were seen with four fully grown young.

Habitat: Primarily a species of Lowland Deciduous Forest and adjacent edge habitats.

\section{Long-billed Marsh Wren (Cistothorus palustris)}

Status: Regular migrant and nesting species.

Migration: Fairly common migrant in the Western Upland and Central Plain, uncommon to rare and local in the Northern Highland. Spring migrants arrive in the Western Upland 25-30 April and the Northern Highland 1-5 May. Peak abundance during spring migration occurs 10-20 May. Fall migration begins in late August. Peak abundance in the Western Upland occurs 5-15 September and departure by 15 October.

Nesting Season Distribution: Uncommon and local nesting species in the Western Upland and Central Plain, rare and local in the Northern Highland. Evidence of nesting has been obtained in Burnett, Chisago, Polk, St. Croix, and Washington counties.

Habitat: A characteristic nesting species of seasonally, semipermanently, and permanently flooded wetlands. Principal vegetation associated with long-billed marsh wren nesting habitat includes cattail, hardstem bulrush, river bulrush, burreed, and phragmites. This species nests in reduced numbers along the edges of more acidic northern Forest Bordered Wetlands and in emergent vegetation along rivers.

\section{Short-billed Marsh Wren (Cistothorus platensis)}

Status: Regular migrant and nesting species.

Migration: Common migrant in the Western Upland and Central Plain, uncommon and local in the Northern Highland. Spring migrants arrive in the Western Upland 25-30 April and the Northern Highland 1-5 May. Peak spring migration through the Valley occurs 15 May to 5 June. Fall migration begins during early August with a gradual exodus from nesting areas. 
Peak fall migration occurs 25 August to 10 September and departure by 1 October.

Nesting Season Distribution: Common to abundant nesting species in the Western Upland and Central Plain, uncommon and local in the Northern Highland. Breeding Bird Survey data (Table 5) suggest that the greatest abundance occurs in the Central Plain.

Habitat: In the Central Plain and Northern Highland, the species is found in Northern Sedge Meadow dominated by tussock sedge, manna grass, and bluejoint grass. In the Western Upland, breeding pairs are frequently encountered in Shrub Carr Wetlands. During dry years, this wren also uses alfalfa and timothy hayfields, Managed Grasslands, and occasionally Old Field Community.

FAMILY MIMIDAE: Mockingbirds and Thrashers

\section{Mockingbird (Mimus polyglottos)}

Status: Casual visitor.

Records: The first record was obtained at Crex Meadows, Burnett County, on 7 May 1958 (MacBriar 1958). One was recorded at Crex Meadows on 5 and 16 May 1964 (Soulen 1965). Two were recorded in Washington County on 23 May 1978 (Willard 1971) and 19 July 1978 (Green 1979). Single mockingbirds were observed at Crex Meadows on 10 May 1975 and 23 May 1976 (M. Link, personal communication), and on 18 May 1980 (D. D. Tessen, personal communication). Faanes and Goddard (1976) cited a 25 April 1976 record from near Woodville, St. Croix County.

\section{Gray Catbird (Dumetella carolinensis)}

Status: Regular migrant and nesting species, casual in winter.

Migration: Common (locally abundant) migrant throughout the Valley. Spring migrants arrive in the Western Upland 1-5 May and the Northern Highland 5-10 May. Peak spring abundance occurs 10-20 May. Fall migration begins in mid-August. Peak fall migration occurs 5-20 September and departure 5-10 October.

Nesting Season Distribution: Fairly common (locally common) nesting species in the Western Upland, common in the Central Plain and fairly common in the Northern Highland. Goddard (1972) found the gray catbird the most abundant nesting species in the Kinnickinnic River Valley, Pierce County. Breeding density in that area was 48.9 pairs per 40 ha. Breeding Bird Survey data (Table 5) show that this species is well distributed throughout the Valley and that greatest densities occur in the Central Plain.

Winter: Polk County records include 9 January to 30 March 1956 at Luck (Lound and Lound 1957a), and December 1956 to 17 January 1957 (Lound and Lound 1957b). A single gray catbird remained at a Newport feeder 
(Washington County) until 27 December 1964 (Huber 1965). One observed at St. Croix Falls, Polk County, on 9 March 1948 may have wintered locally (Robbins 1948c).

Habitat: Primarily a species of deciduous forest edge habitats. Important among these are second-growth Northern Hardwood Forest, Deciduous Clear Cuts, Old Field Community, and fencerows. Lowland Deciduous Forest is occasionally used in the Western Upland and Black Spruce-Tamarack Bogs receive limited use in the Northern Highland. In residential areas, ornamental shrubbery is used.

\section{Brown Thrasher (Toxostoma rufum)}

Status: Regular migrant and nesting species, casual early winter resident.

Migration: Common migrant in the Western Upland and Central Plain, fairly common in the Northern Highland. Spring migrants arrive in the Western Upland 20-25 April (earliest-4 April 1975, Washington County) and reach the Northern Highland 25-30 April. Peak spring abundance occurs 1-15 May. Fall migration begins 15-30 August; peak movements occur 5-20 September and departure by 10 October.

Nesting Season Distribution: Common nesting species in the Western Upland and Central Plain, fairly common and more local in the Northern Highland. Jackson (1943) reported this species as "not common" in northwestern Wisconsin in 1919 but almost 50 years later, Bernard (1967) considered brown thrashers "common" in Douglas County. Breeding Bird Survey data (Table 5) suggest a gradual decrease in relative abundance moving northward across the Valley. Major changes in abundance appear to occur between the Central Plain and Northern Highland. Goddard (1972) reported a breeding density of 6.4 pairs per 40 ha in the Kinnickinnic River Valley, Pierce County.

Winter: There are three early winter records from Washington County: 20 December 1969, 29 December 1973, and 1 January 1975. One remained at a Pierce County feeder through 11 January 1976 (Faanes and Goddard 1976).

Habitat: Primarily a species of edge habitats. Important among these are natural clearings in Southern Deciduous Forest, Old Field Community, brushy fencerows, and Deciduous Clear Cuts. Recently logged oak forests and grazed woodlots supporting an abundance of prickly ash and hawthorn are frequently used in the Western Upland.

FAMILY TURDIDAE: Thrushes, Solitaires, and Bluebirds

\section{American Robin (Turdus migratorius)}

Status: Regular migrant, nesting species, and winter resident.

Migration: Abundant migrant throughout the Valley. The first spring mi- 
grants arrive in the Western Upland during the first 10 days of March, reaching the Northern Highland 15-25 March. Peak spring migration through the Valley occurs 25 March to 15 April. Fall migration begins during late August with the formation of loose feeding flocks. Peak fall migration occurs 15 September to 10 October and most have departed by 1 November. During the peak of fall migration, flocks of 50 to 75 individuals are regularly encountered and occasional groups of 200 to 250 have been recorded.

Nesting Season Distribution: Abundant nesting species in the Western Upland and Central Plain, common in the Northern Highland. Jackson (1943) considered the American robin abundant throughout northwestern Wisconsin in 1919. Breeding Bird Survey data (Table 5) show that the American robin is by far the most numerous nesting thrush in the Valley. Goddard (1972) recorded a nesting density of 18.4 pairs per 40 ha in the Kinnickinnic River Valley, Pierce County.

Winter: This species is fairly well distributed throughout the Valley; several midwinter records exist from Burnett, Douglas, and Pine counties. American robins are regularly observed during midwinter in the Western Upland and appear to be dependent on trees and shrubs (mountain ash, cedar) that retain their fruits throughout the period.

Habitat: Breeding American robins are found in nearly all habitat types in the Valley. This species has adapted well to man's continued alteration of the Valley and is a common breeding species in park-like Residential Habitats. The establishment of Pine Plantations, particularly in the Western Upland and Central Plain, has provided increased areas of excellent nesting habitat.

\section{Varied Thrush (Ixoreus naevius)}

\section{Status: Casual winter visitor.}

Records: This western thrush has been recorded in the Valley at least seven times. Minnesota records include one at Stillwater, Washington County, from mid-December to $30 \mathrm{March} 1974$ (Eckert 1974). Additional Washington County records include single birds on 3 January 1976, late November 1976, and 9 January 1977. Longley (1967) observed a single bird in Chisago County on 13 November 1966. Records from the Wisconsin counties include one bird at Osceola, Polk County, from early December 1948 until 21 April 1949 (Simmons 1949). One apparently wintering bird remained near Grantsburg, Burnett County, from 12 November 1963 to midMarch 1964 (Bauers 1964).

Habitat: Varied thrushes in this region are usually found at feeding stations. Surrounding habitats include Southern Deciduous Forest composed primarily of Hill's and white oak and brushy edges.

\section{Wood Thrush (Hylocichla mustelina)}

Status: Regular migrant and nesting species. 
Migration: Uncommon migrant throughout the Valley. Spring migrants arrive in the Western Upland 1-5 May, reaching the Northern Highland 10-15 May. Peak spring migration through the Valley occurs 10-25 May. During late July this species becomes very secretive and is not regularly encountered. Peak fall migration apparently occurs 15-30 August and departure 20-30 September.

Nesting Season Distribution: Uncommon nesting species throughout the Valley. Jackson (1943) found this species "fairly common" at St. Croix Falls and heard it occasionally at Danbury (Burnett County) in 1919. Breeding Bird Survey data (Table 5) show a fairly uniform breeding density throughout the Western Upland and Central Plain. The greatest abundance apparently occurs in the Northern Highland. In Minnesota, however, Green and Janssen (1975) consider it most common south of the latitude occupied by the Twin Cities. Goddard (1972) reported a density of 2.1 pairs per 40 ha in the Kinnickinnic River Valley, Pierce County.

Habitat: In the Western Upland, the wood thrush is most common in mature Southern Deciduous Forest and Lowland Deciduous Forest. Breeding pairs in the Central Plain are most commonly encountered in mesic Northern Hardwood Forest. In the Northern Highland, this species uses Northern Hardwood Forest and is occasionally found in Lowland Coniferous Forest. In all instances, wood thrushes appear to select woodlands with a closed canopy of mature trees.

\section{Hermit Thrush (Catharus guttatus)}

Status: Regular migrant and nesting species.

Migration: Common migrant throughout the Valley. The hermit thrush is the first of the Catharus thrushes to arrive in spring. The first migrants arrive in the Western Upland 5-10 April (earliest-31 March 1967, Washington County) and reach the Northern Highland 10-15 April. Peak spring migration occurs 15-25 April and departure from nonbreeding areas occurs by 10 May. Fall migration begins in late August. Peak abundance occurs 25 September to 15 October and departure by 1 November (latest -5 November 1975).

Nesting Season Distribution: Fairly common nesting species in the Northern Highland, rare and local in the Central Plain (Table 5). Confirmed nest records exist for Douglas and Pine counties, and nesting is inferred in Burnett and Polk counties.

Habitat: This species is characteristic of wet coniferous-deciduous forests in the Northern Highland. Important among these are Lowland Coniferous Forest, Black Spruce-Tamarack Bogs, and low areas of Northern Hardwood Forest. Breeding pairs also use drier portions of Jack Pine Barrens throughout the Northern Highland.

\section{Swainson's Thrush (Catharus ustulatus)}

Status: Regular migrant and probable nesting species. 
Migration: Common spring and abundant fall migrant throughout the Valley. Spring migrants arrive in the Western Upland 5-10 May (earliest30 April 1950, Polk County), reaching the Northern Highland 10-15 May. Peak abundance through the Valley occurs 15-25 May and departure by 5 June (latest-8 June 1968, Polk County). This species is the first of the Catharus thrushes to arrive in the fall. The first migrants arrive in the Western Upland 5-10 August (earliest-27 July 1966, St. Croix County). Peak abundance through the Valley occurs 25 August to 15 September and departure by 10 October.

Nesting Season Distribution: Rare and local in the Northern Highland during the nesting season. There are no confirmed records of nesting in the Valley. Green and Janssen (1975) showed the probable breeding range of this thrush to include northern and central Pine County. Roberts (1932) mentioned records that suggest nesting in Pine County in 1918. I recorded one singing male along the St. Croix River in Douglas County on 20 June 1976. This is my only summer record for the Valley.

Habitat: During migration, Swainson's thrush regularly uses a wide range of deciduous and coniferous communities. My only nesting season record was obtained from a large tract of Lowland Coniferous Forest that was dominated by black spruce, balsam fir, and yellow birch.

\section{Gray-cheeked Thrush (Catharus minimus)}

Status: Regular migrant.

Migration: Uncommon migrant throughout the Valley. Spring migrants arrive in the Western Upland 5-10 May (earliest-1 May 1967, St. Croix County), reaching the Northern Highland about 10 May. Peak migration occurs 15-25 May and departure by 5 June. Fall migrants arrive in the Northern Highland in mid-August, reaching the Western Upland 25-30 August. Peak fall migration occurs 5-15 September and departure by 1 October.

Habitat: Largely restricted to mature tracts of Upland and Lowland Deciduous Forest in the Western Upland. In the Central Plain and Northern Highland, this species is most numerous in Northern Hardwood and Lowland Coniferous Forests.

\section{Veery (Catharus fuscescens)}

Status: Regular migrant and nesting species.

Migration: Common migrant throughout the Valley. Spring migrants arrive in the Western Upland 25 April to 1 May, reaching the Northern Highland 1-5 May. Peak spring migration through the Valley occurs 10-25 May. Fall migration begins in early August. Peak abundance occurs 20 August to 10 September and departure by 1 October.

Nesting Season Distribution: Common nesting species in the Northern Highland and Central Plain, uncommon to rare and local in the Western 
Upland. Jackson (1943) reported that the veery was common throughout northwestern Wisconsin. The southern limit of the breeding range is closely associated with the southern limit of maple-basswood forest. This range limit occurs about at the latitude occupied by Marine-on-St. Croix, Washington County. Breeding Bird Survey data (Table 5) suggest a rapid increase in relative abundance moving northward across the Valley.

Habitat: Primarily a species occupying various age classes of moist deciduous forest. In the Northern Highland and Central Plain, this species uses mature stands of Northern Hardwood Forest dominated by sugar maple, basswood, trembling aspen, and white birch. Alder Thicket, Lowland Coniferous Forest, and Black Spruce-Tamarack Bogs are also used in these regions. In the Western Upland, habitat use is almost entirely restricted to mixed maple-oak Forest. Occasional use is made of Shrub Carr wetlands that support an abundant growth of silver willow.

\section{Eastern Bluebird (Sialia sialis)}

Status: Regular migrant and nesting species, casual in winter.

Migration: Fairly common spring and fall migrant in the Western Upland and Central Plain, more localized in the Northern Highland. Spring migrants arrive in the Western Upland 20-30 March (earliest-12 March 1966. Washington County and 12 March 1977, Pierce County) and the Northern Highland about 1 April. Peak abundance through the Valley occurs 15-30 April. Fall migration begins with the formation of loose family groups in mid-August. Peak fall abundance occurs 15 September to 10 October and departure by 1 November (latest-30 November 1967, Washington County). On 17 October 1964, W. E. Scott observed an estimated 200 eastern bluebirds near St. Croix Falls, Polk County (Kemper 1965).

Nesting Season Distribution: Fairly common nesting species throughout the Valley. Jackson (1943) found this species common in northwestern Wisconsin, especially in recently burned areas. Breeding Bird Survey data (Table 5) suggest that a fairly uniform abundance exists throughout the Western Upland and Central Plain, except in the Jack Pine Barren region along the Union transect, Burnett County.

Concern has been expressed about the status of the eastern bluebird in North America (cf. Arbib 1978) and in Wisconsin (R. L. Hine, personal communication). Some authorities believe that population declines are related to mortality on the wintering grounds, whereas others believe these declines are related to competition for nest sites with other hole-nesting species (e.g., house sparrow). Careful monitoring of the Valley population should be undertaken to determine if declines are occurring.

Winter: One bird was observed at St. Croix Falls, Polk County, on 7 and 8 February 1948. Two birds were observed in Washington County on 20 December 1969. Roberts (1932) mentioned, without details, winter records from Washington County.

Habitat: The eastern bluebird is a characteristic species of edge and open habitats including fencerows, early successional stage deciduous forest, 
Deciduous Clear Cuts, and openings in grazed woodlots. In the Northern Highland and Central Plain, extensive use is made of Jack Pine Barrens. This is evidenced by the high relative abundance of this species along the Union BBS transect, Burnett County. Local populations, particularly in agricultural areas, can be enhanced by the establishment and monitoring of bluebird houses. Many 4-H Clubs and Future Farmers of America (FFA) chapters have created "Bluebird Trails" that are very beneficial in providing nesting sites.

\section{Townsend's Solitaire (Myadestes townsendi)}

Status: Accidental.

Records: One Townsend's solitaire was observed at Hudson, St. Croix County, from December 1942 to 10 January 1943 (Scott 1943a). Longley (1973a) described the observation of a single bird in Chisago County on 27 April 1973.

\section{FAMILY SYLVIIDAE: Gnatcatchers and Kinglets}

\section{Blue-gray Gnatcatcher (Polioptila caerulea)}

Status: Regular migrant and nesting species.

Migration: Uncommon and local migrant restricted primarily to the Western Upland. Spring migrants arrive 1-5 May and are most conspicuous after 15 May. Fall migration apparently begins in late July with dispersal of family groups. This species is most common during the fall 1-15 August and departure occurs by 25 August latest-6 September 1975, Washington County).

Nesting Season Distribution: Uncommon and local nesting species in the Western Upland. Occasional summer records at St. Croix Falls, Polk County, suggest possible nesting. The observations by Breckenridge (in Roberts 1932) and Maurer (1970) of nests at Marine-on-St. Croix are probably the northernmost documented records in the Valley. Breckenridge reported two adults, but no young, at Taylor's Falls, Chisago County, on 11 August 1938 (Erickson and Upson 1938). The area of greatest abundance is restricted to the lower St. Croix River and its major tributaries from Stillwater, Washington County, south to its confluence with the Mississippi River.

The status of this species as a nesting bird in the Valley is apparently changing. Robbins (1963) suggested that as of 1962 blue-gray gnatcatchers "may not be counted on to be present every year" at Hudson, St. Croix County. Since first observing nesting pairs along the Willow River at Hudson in 1973, the number of pairs on one site has risen from 7 in 1973 to 17 in 1978. Expansion of this species along major St. Croix River tributaries in Wisconsin is also evident. During 1976 and 1977, breeding pairs were located along the Kinnickinnic River near Roberts, St. Croix County (Sec. 11, T. 28 N., R. 18 W.), along the Willow River near Jewett, St. Croix County 
(Sec. 4, T. 30 N., R. 17 W.), and along the Apple River near Amery, Polk County (Sec. 8, T. 32 N., R. 17 W.). Expansion along streams that are tributary to the St. Croix River in Washington County has also been observed.

Habitat: Characteristic species of mature tracts of Lowland Deciduous Forest along the St. Croix and its tributaries. Several breeding pairs located along the Lower Kinnickinnic River, Pierce County, in 1976 were using medium-aged Southern Deciduous Forest that was dominated by white oak and Hill's oak. The territories occupied by five pairs in 1976 and seven pairs in 1977 along the Willow River were associated with sapling cottonwood and green ash in the Lowland Forest. Three nests were placed from 2.1 to $6.1 \mathrm{~m}$ above the ground in young green ash trees.

\section{Golden-crowned Kinglet (Regulus satrapa)}

Status: Regular migrant and winter resident.

Migration: Fairly common migrant throughout the Valley. Spring migrants arrive in the Western Upland 15-25 March, reaching the Northern Highland 25-30 March. Peak abundance through the Valley occurs 5-25 April and departure by 15 May. Green and Janssen (1975) stated that the St. Croix River Valley can be included in this species' breeding range in Minnesota, although there are no breeding records to support this. Fall migrants arrive in the Northern Highland in mid-September, reaching the Western Upland 25 September to 1 October. Peak fall abundance occurs 15 October to 1 November and most have departed by 1 December.

Winter: Uncommon to rare and local winter resident in the Western Upland, casual in the Northern Highland where several late December records have been obtained.

Habitat: During migration and winter, this species is most commonly observed in coniferous communities and occasionally in Lowland Deciduous Forest. Most important among coniferous habitats are Pine Plantations and Lowland Coniferous Forest dominated by black spruce, balsam fir, and hemlock.

\section{Ruby-crowned Kinglet (Regulus calendula)}

Status: Regular migrant, casual summer and early winter resident.

Migration: Common spring and fall migrant throughout the Valley. Spring migrants arrive in the Western Upland 5-10 April, reaching the Northern Highland by 15 April. Peak abundance occurs 1-10 May and departure by 25 May. A female collected at St. Croix Falls, Polk County, on 22 May 1919. was considered a migrant (Jackson 1943). Fall migrants arrive in the Northern Highland 1-10 September, reaching the Western Upland about 10 September (earliest-23 August 1963, St. Croix County). Peak fall abundance occurs 25 September to 10 October and departure by 30 October.

Nesting Season Distribution: There are no documented nest records in the Valley. Green and Janssen (1975) showed that the breeding range of this 
species in Minnesota extended south to the northern border of Pine County. On 20 and 21 June 1976, I observed two singing male ruby-crowned kinglets along the St. Croix River in Douglas County (Sec. 24, T. 43 N., R. 14 W.). Although the behavior of these birds suggested nesting. I failed to observe nests or young.

Winter: Casual early winter resident in the Western Upland, usually observed during the CBC period. The latest observations are two birds on the Afton CBC 1 January 1976.

Habitat: During migration, this species uses a wide range of both deciduous and coniferous communities. During these periods, ruby-crowned kinglets appear to prefer brushy communities including Deciduous Clear Cuts. The singing males that I recorded in Douglas County were in an extensive Lowland Coniferous Forest dominated by black spruce, balsam fir, and yellow birch.

\section{FAMILY MOTACILLIDAE: Pipits}

\section{Water Pipit (Anthus spinoletta)}

Status: Regular migrant.

Migration: Uncommon migrant in the Western Upland and Central Plain, rare or absent in the Northern Highland. Spring migrants arrive in the Western Upland 25 April to 5 May. Peak spring abundance through the Valley occurs 10-20 May and departure by 25 May. Fall migrants arrive during mid-September. Peak fall abundance occurs 25 September to 10 October and departure by 25 October.

Habitat: Primary habitat includes seasonally flooded wetlands, agricultural fields, and man-made impoundments that are managed for waterfowl production. During fall migration, this species is especially numerous in recently plowed agricultural fields.

\section{FAMILY BOMBYCILLIDAE: Waxwings}

\section{Bohemian Waxwing (Bombycilla garrulus)}

Status: Casual migrant and winter resident.

Migration: This species is erratic in both distribution and abundance. The highest frequency of occurrence appears to be in the Western Upland. Although fall arrival periods are not regular, small flocks begin to arrive 20 November to 15 December. Spring departure is also irregular; most flocks leave by mid-March (latest-6 April 1970, Washington County).

Winter Distribution: An irregular winter resident throughout the Valley. Observations of Bohemian waxwings during midwinter usually consist of flocks of 15 to 30 birds. Most records have been obtained during the CBC period during the last 2 weeks of December. 
Habitat: Most of my observations have involved birds foraging at the edge of deciduous forests or flocks in residential areas. The existence of vegetation that retains its fruit into the winter is important in maintaining this waxwing. Among these plants mountain ash and flowering crab apple, established as ornamentals in residential areas, are most important.

\section{Cedar Waxwing (Bombycilla cedrorum)}

Status: Regular migrant, nesting species, and winter resident.

Migration: Common to abundant spring and fall migrant throughout the Valley. Determination of arrival dates is compounded by the irregular nature of waxwing movements. During years when winter populations are very low, the first noticeable influx of migrants occurs 1-20 May, reaching a peak 1-15 June. When summer populations are low, fall movements occur from mid-August through 30 November and peak abundance usually occurs during late September.

Nesting Season Distribution: Fairly common nesting species throughout the Valley. Jackson (1943) reported that cedar waxwings were common throughout most of northwestern Wisconsin during the 1919 nesting season. Breeding Bird Survey data suggest that the largest population occurs in the Central Plain and Northern Highland. Goddard (1972) reported a density of 9.7 pairs per 40 ha in the Kinnickinnic River Valley, Pierce County.

Winter: Common to abundant winter resident in the Western Upland and Central Plain, uncommon in the Northern Highland. Yearly winter populations are characterized by large fluctuations, probably related to the abundance and availability of a food source. This species, like the Bohemian waxwing, is closely associated with fruit-bearing trees during the winter.

Habitat: Primarily a species of open or semi-open deciduous forest. Important among these habitats are openings in Southern Deciduous Forest, Northern Hardwood Forest, and Deciduous Clear Cuts. Nesting cedar waxwings also use, to a lesser extent, coniferous communities and ornamental shrubbery in residential areas.

\section{FAMILY LANIIDAE: Shrikes}

\section{Northern Shrike (Lanius excubitor)}

Status: Regular migrant and winter resident.

Migration: Uncommon to rare migrant throughout the Valley. The first fall migrants arrive in the Northern Highland 20-30 October, reaching the Western Upland 1-15 November learliest-22 October 1976, St. Croix County). This species is most frequently encountered 20 November to 10 January. During spring migration, peak numbers occur 1-15 March and departure by 15 April (latest-26 April 1953. Burnett County). 
Winter: Rare winter resident throughout the Valley, most regularly observed in the Western Upland and Central Plain.

Habitat: Primarily a species of semi-open natural habitats and agricultural communities during migration and winter. Most northern shrikes are observed perched near the edge of wooded habitats and open fields or along fencerows and highway rights-of-way. The northern shrike is observed infrequently in coniferous habitat including Lowland Coniferous Forest and Black Spruce-Tamarack Bogs.

\section{Loggerhead Shrike (Lanius ludovicianus)}

Status: Regular migrant and nesting species, accidental in winter.

Migration: Formerly common throughout the Valley, this species is now rare during migration. The spring migration period extends from early April (earliest-27 March 1954, Burnett County) through early May. Fall migration occurs from late August through mid-October (latest-2 November 1972, Burnett County). Caution must be exercised when identifying shrikes during April and October, because their plumage is similar to the northern shrike.

Nesting Season Distribution: Formerly a fairly common breeding species; breeding was documented as far north as Solon Springs in Douglas County. Jackson (1943) noted that "several birds were seen in the open pine barrens five miles south of Solon Springs on 4 August 1919, where two families of full grown young were located." Within the last 15 years, however, the status of the loggerhead shrike during the nesting season has changed. Erdman (1970) summarized the status and distribution of this shrike in Wis. consin, concluding that it was experiencing a statewide decline. Erdman provided information on a nest site near Clayton, Polk County, that is now the northernmost location in the Valley. Loggerhead shrikes were observed in southern Pine County during the 1974 nesting season (Eckert 1974). However, no nests or young were found.

During 1977, I located two nesting pairs that produced five young in St. Croix County. In 1978, five pairs were located in that county, primarily between Roberts and New Richmond. I observed an additional pair during July about $6.4 \mathrm{~km}$ south of Lake Elmo, Washington County.

Winter: There are two records of the loggerhead shrike during winter including one bird in Washington County on 1 January 1976. R. E. Faanes observed the other bird hunting near a bird feeder in Hudson, St. Croix County, on 15 February 1978.

Habitat: Primarily a species of edge habitats including fencerows, thorny hedgerows, and brush areas associated with grazed deciduous woodlots. Current clean farming practices, including fencerow removal, may be responsible for some of the decline observed in the breeding population. 


\section{FAMILY STURNIDAE: Starlings}

\section{Starling (Sturnus vulgaris)}

Status: Introduced. Regular migrant, nesting species, and winter resident.

Migration: Abundant migrant in the Western Upland and Central Plain, less common in the Northern Highland. Dates of spring arrival are difficult to determine because of wintering individuals. However, large increases in the population occur from late February through 20 March. During fall migration, flocks begin forming in early August and peak movements occur 15 September to 15 October.

Nesting Season Distribution: Abundant nesting species in the Western Upland and Central Plain; uncommon and local in the Northern Highland. The first record of this species in the Valley was obtained from St. Croix County in 1937 (Anonymous 1939). Since that time, the starling population has expanded and the species now breeds throughout the Valley. Breeding Bird Survey data show that largest populations occur in areas heavily settled by humans and where agriculture has expanded. The mean number of starlings recorded along the route of the Dresser BBS (Polk County) is 44.3; however, in the heavily forested region traversed by the Union BBS route (Burnett County), this species was not recorded.

Winter: Common to locally abundant winter resident in the Western Upland, fairly common in the Central Plain, and uncommon to rare or absent in the Northern Highland. During this period, large flocks of starlings are associated with cattle feedlots or barnyards in agricultural areas, and near feedmills and feeder operations in residential areas.

Habitat: Starlings nest in a variety of vegetation types, and in residential buildings, or in nest boxes erected for other species. Starlings have been considered an important factor in the decline of several more desirable species including the red-headed woodpecker and eastern bluebird. Because starlings return to their breeding areas and establish territories earlier than other hole-nesting species, they dominate these nest sites before other migrants return.

\section{FAMILY VIREONIDAE: Vireos}

\section{White-eyed Vireo (Vireo griseus)}

Status: Accidental.

Record: An adult white-eyed vireo was trapped and banded at the Warner Nature Center, Washington County, on 3 May 1977 (Wojahn 1977).

\section{Bell's Vireo (Vireo bellii)}

Status: Casual migrant and summer resident. 
Records: Five records exist during 13 May to 7 September: Polk County, 18 May 1974; Chisago County, 7 September 1968; and St. Croix County, 13 May 1964, 17 June to 21 July 1977, and 3 July 1963. The 1977 St. Croix County record may have been a breeding pair. One male was observed almost daily on territory $5.6 \mathrm{~km}$ east of New Richmond. The male was heard singing and appeared to be defending a breeding territory. Attempts to locate a nest or a mated female failed.

Habitat: The 1977 observation was of a bird in second-growth Lowland Deciduous Forest along the Willow River.

\section{Yellow-throated Vireo (Vireo flavifrons)}

Status: Regular migrant and nesting species.

Migration: Uncommon migrant in the Western Upland and Central Plain, rare and local in the Northern Highland. Spring migrants arrive in the Western Upland 5-10 May and the Northern Highland 10-15 May and are well distributed 15-25 May. Fall migration begins about 15 August. Peak movements occur 25 August to 10 September and departure 20-25 September.

Nesting Season Distribution: Fairly common nesting species in the Western Upland and Central Plain, uncommon and local in the Northern Highland. Jackson (1943) recorded this species nesting at St. Croix Falls, Polk County; however, he failed to obtain records elsewhere in northwestern Wisconsin. Bernard (1967) considered this vireo an "uncommon to rare summer resident" in Douglas County. Nesting records have been obtained from Solon Springs, which is at the northern limit of their range in Wisconsin. There are several nest records for Chisago and Pine counties, the farthest north at St. Croix State Park, Pine County (Sparkes 1953). Breeding Bird Survey data (Table 6) indicate that the breeding population is fairly uniform throughout the Valley. Goddard reported a density of 2.9 pairs per 40 ha in the Kinnickinnic River Valley, Pierce County.

Habitat: A characteristic breeding bird of mature deciduous forests. During the breeding season, this species is most commonly found in Northern Hardwood Forest and Lowland Deciduous Forest. Occasional breeding pairs are recorded in residential habitats and in Lowland Coniferous Forest.

\section{Solitary Vireo (Vireo solitarius)}

Status: Regular migrant and nesting species.

Migration: Uncommon to fairly common migrant throughout the Valley. Spring migrants arrive in the Western Upland 1-5 May, reaching the Northern Highland by 10 May. Peak spring migration occurs 10-20 May and departure from nonbreeding areas is by 30 May. Fall migration begins in the Northern Highland in mid-August. The first migrants reach other regions by 25 August. Peak fall migration occurs 10-20 September and departure by 30 September (latest-27 October 1970, Pine County). 
Table 6. Mean number of vireos and warblers recorded on western Wisconsin Breeding Bird Survey transects, 1966-78.

\begin{tabular}{|c|c|c|c|c|c|}
\hline \multirow[b]{2}{*}{ Species } & \multirow{2}{*}{$\begin{array}{l}\text { Western } \\
\text { Upland } \\
\text { Hudson }\end{array}$} & \multicolumn{2}{|c|}{ Central Plain } & \multicolumn{2}{|c|}{ Northern Highland } \\
\hline & & Dresser & Loraine & Union & Minong \\
\hline \multicolumn{6}{|l|}{ Vireos } \\
\hline Yellow-throated & 1.2 & 1.7 & 2.8 & 3.8 & 2.0 \\
\hline Solitary & 0.0 & 0.0 & 0.2 & 0.0 & 1.2 \\
\hline Red-eyed & 3.6 & 6.6 & 21.3 & 16.1 & 41.2 \\
\hline Warbling & 6.1 & 13.1 & 10.7 & 3.8 & 5.4 \\
\hline \multicolumn{6}{|l|}{ Warblers } \\
\hline Black-and-white & 0.0 & $<0.1$ & 1.3 & $<0.1$ & 6.9 \\
\hline Blue-winged & $<0.1$ & 0.0 & 0.0 & 0.0 & 0.0 \\
\hline Golden-winged & 0.0 & 0.3 & 5.1 & 0.0 & 2.5 \\
\hline Nashville & 0.0 & $<0.1$ & 1.4 & 1.7 & 20.2 \\
\hline Yellow & 2.5 & 5.8 & 21.9 & 1.6 & 8.0 \\
\hline Magnolia & 0.0 & 0.0 & 0.0 & 0.0 & $<0.1$ \\
\hline Cape May & 0.0 & 0.0 & 0.0 & 0.0 & $<0.1$ \\
\hline Yellow-rumped & 0.0 & 0.0 & 0.0 & 0.2 & 1.9 \\
\hline Black-throated green & 0.0 & 0.0 & 0.0 & 0.0 & 0.6 \\
\hline Blackburnian & 0.0 & 0.0 & 0.0 & $<0.1$ & 0.2 \\
\hline Chestnut-sided & 0.3 & 0.2 & 5.2 & 3.9 & 29.8 \\
\hline Pine & 0.0 & 0.0 & 0.3 & 0.4 & 3.8 \\
\hline Ovenbird & 0.0 & 0.5 & 4.7 & 23.7 & 19.0 \\
\hline Common yellowthroat & 7.9 & 12.6 & 36.2 & 14.6 & 36.2 \\
\hline Mourning & 0.0 & $<0.1$ & 1.2 & $<0.1$ & 6.3 \\
\hline Connecticut & 0.0 & 0.0 & 0.0 & 1.7 & 2.7 \\
\hline Canada & 0.0 & 0.0 & $<0.1$ & 0.0 & 1.7 \\
\hline American redstart. & 0.0 & 0.6 & 5.2 & 0.3 & 7.9 \\
\hline
\end{tabular}

Nesting Season Distribution: Documented evidence of nesting by this vireo exists only for Douglas County, where I observed an adult incubating on 11 June 1977. This bird was found along the St. Croix River about $6.4 \mathrm{~km}$ west of Gordon, Wisconsin. Although there is considerable evidence of nesting in Burnett and Pine counties, neither nests or young have been observed. Breeding Bird Survey data (Table 6) also suggest that nesting is primarily restricted to the Northern Highland.

Habitat: Solitary vireos are characteristic of Lowland Coniferous Forest. Vegetation associated with the Douglas County nest site was Lowland Coniferous Forest dominated by black spruce and white cedar adjacent to the St. Croix River. Additional observations within the breeding range occur in similar habitat or in Black Spruce-Tamarack Bogs.

\section{Red-eyed Vireo (Vireo olivaceus)}

Status: Regular migrant and nesting species. 
Migration: Common (locally abundant) migrant throughout the Valley. Spring migrants arrive in the Western Upland 10-15 May, reaching the Northern Highland by 20 May. The peak of migration occurs 20 May to 5 June. Fall migration begins 20-25 August. Peak abundance occurs 10-15 September and departure by 5 October.

Nesting Season Distribution: Fairly common nesting species in the Western Upland, common to locally abundant in the Central Plain and Northern Highland. Goddard (1972) reported this vireo to be among the 10 most abundant breeding birds in the Kinnickinnic River Valley, Pierce County. Mean density in that area was 25.3 pairs per 40 ha. Analysis of BBS data (Table 6) indicates a gradation in abundance moving northward through the Valley. Documented nesting records exist for Polk, St. Croix, and Washington counties and there is evidence of nesting in the other counties.

Habitat: Red-eyed vireos are largely restricted to various deciduous forest types during migration and the nesting season. Although not characteristic of any one habitat type, their abundance is predictable when compared among geomorphic regions.

In the Western Upland, highest breeding densities occur in mature Lowland Deciduous Forest and mature Southern Deciduous Forest. In the Central Plain, breeding populations are greatest in mature Northern Hardwood Forest dominated by sugar maple and basswood. In the Northern Highland, populations are greatest in aspen forest and mature Northern Hardwood Forest.

\section{Philadelphia Vireo (Vireo philadelphicus)}

Status: Regular migrant.

Migration: Uncommon to rare migrant throughout the Valley. This is the latest arriving vireo; average first appearance is 15 May in the Western Upland. Migrants arrive in the Northern Highland about 20 May. Observations usually are of single birds or occasionally pairs; therefore, peak migration cannot be determined. Spring departure from the southern regions occurs by 30 May and from the Northern Highland by 5 June. Fall migrants arrive $10-15$ September. This species is most frequently encountered 15-25 September and departs from 30 September to 5 October (latest29 October 1970, Washington County).

Habitat: Philadelphia vireos use a variety of habitat types during migration; however, they are most regularly observed in medium-aged to mature Northern Hardwood Forest.

\section{Warbling Vireo (Vireo gilvus)}

Status: Regular migrant and nesting species.

Migration: Common migrant in the Western Upland; fairly common in the Central Plain and Northern Highland. Fairly common fall migrant in the Western Upland, uncommon to rare elsewhere. The mean date of spring arri- 
val in the Western Upland is 8 May (earliest-1 May 1976, St. Croix County) and migrants reach the Northern Highland 10-15 May. Peak migration through the Valley occurs 15-25 May. Fall migration begins 10-15 August. Peak fall migration occurs 20 August to 5 September and departure by 20 September. Peak fall migration in the Western Upland occurs 10-20 September and departure by 1 October.

Nesting Season Distribution: Fairly common to locally common nesting species in the Western Upland and Central Plain, rare to locally uncommon in the Northern Highland. Jackson (1943) considered this vireo to be uncommon when compared with the red-eyed vireo in northwestern Wisconsin. Bernard (1967) described this species as a "regular but generally uncommon summer resident" in Douglas County. Breeding Bird Survey data (Table 6) indicate a fairly constant abundance throughout the Valley. Nesting has been documented in all counties.

Habitat: Characteristic nesting species of mature Lowland Deciduous Forest. Highest breeding densities occur in that habitat and mature Northern Hardwood Forest. Other habitats frequently used include Southern Deciduous Forest, Deciduous Clear Cuts, and Residential Habitats.

\section{FAMILY PARULIDAE: Wood Warblers}

\section{Black-and-white Warbler (Mniotilta varia)}

Status: Regular migrant and nesting species.

Migration: Fairly common migrant throughout the Valley. Jackson (1943) reported that the black-and-white warbler was "the most abundant of warblers" during the 1919 spring migration in Polk and Burnett counties. Earliest spring migrants arrive in the Western Upland during the last 5 days of April, reaching the Northern Highland 1-5 May. Peak migration occurs 10-20 May, and nonbreeders depart by 25 May. Fall migration begins in mid-August and birds reach the Western Upland 20-25 August. Peak fall migration occurs 10-20 September, and most have departed by 5 October.

Nesting Season Distribution: Uncommon and local nesting species, most frequently encountered in the Northern Highland. Green and Janssen (1975) indicated the breeding range of this warbler extended into northern Washington County. My Minnesota breeding season records have been obtained only in southern Pine County. Confirmed nesting records exist only for Polk County (12 June 1975). Breeding Bird Survey data (Table 6) suggest a rapid increase in relative abundance moving northeast through the Valley. The 12year mean number of males recorded on Dresser BBS is $<0.1$, increasing to 1.3 on the Loraine BBS, and 6.9 on Minong.

Habitat: Territorial males have been recorded in both deciduous and coniferous habitats during the breeding season. In deciduous areas, a preference is shown for mature Northern Deciduous Forest, characterized by extensive stands of maple and basswood. This species apparently prefers Northern 
Coniferous Forest, Black Spruce-Tamarack Bog, and white cedar communities.

\section{Prothonotary Warbler (Protonotaria citrea)}

Status: Regular migrant and nesting species.

Migration: Rare migrant in the Western Upland; one record from the Central Plain (7 May 1966, Chisago County). Observations of this warbler are insufficient to determine patterns of spring and fall migration. Most records appear to be birds on or near potential nesting territories. Spring migrants are usually first recorded 10-15 May (earliest-4 May 1974, Pierce County). Records of fall migrants are even more irregular; the latest is 10 September 1975 (St. Croix County). Most observations of this bird during migration periods have been restricted to areas along and adjacent to the St. Croix River in Pierce, St. Croix, and Washington counties.

Nesting Season Distribution: Very rare nesting species, apparently restricted to the Western Upland. Maurer (1970) briefly described the observation of a nest near Marine-on-St. Croix (Washington County) containing one young on 5 July 1970 . On 10 July 1945,11 male prothonotary warblers were found on territory between Marine-on-St. Croix and Stillwater, and three females were observed feeding near nests (Hubert 1945). On 28 June 1945, a single male was observed along the St. Croix River near Osceola, Polk County. Observations of territorial males along the lower reaches of the Kinnickinnic, Willow, and Apple rivers provide evidence of possible additional breeding records.

Habitat: The prothonotary warbler is restricted almost entirely to large stands of mature Lowland Deciduous Forest dominated by cottonwood. green ash, and American elm. The brief description of the habitat near the nest Maurer observed suggests a mixture of willow and basswood.

\section{Worm-eating Warbler (Helmitheros vermivorus)}

Status: Casual, three spring records.

Records: S. D. Robbins heard and saw one male along Trout Brook Road near Hudson, St. Croix County, on 18 May 1969 (Faanes and Goddard 1976). Maurer (1969) described the observation of a wormeating warbler in Washington County on 18 May 1969. I observed one near Trout Brook Road in St. Croix County on 18 May 1980 . This species has been recorded with increasing frequency in central Minnesota and southern Wisconsin and may become more regular in the lower reaches of the Valley.

\section{Golden-winged Warbler (Vermivora chrysoptera)}

Status: Regular migrant and nesting species.

Migration: Uncommon migrant throughout the Valley. Spring migrants arrive in the Western Upland 5-10 May, and reach the Northern Highland 
about 15 May. Jackson (1943) reported that golden-winged warblers were "common" along the St. Croix River near St. Croix Falls from 21-25 May 1919. One pair was observed copulating on 22 May 1919. This warbler apparently migrates singly, or in small very loose flocks; thus periods of peak spring abundance are difficult to determine. Spring migrants have departed nonbreeding areas in the Western Upland by 30 May. Fall migrants reach the Western Upland about 10 August. Peak fall movements occur 20 August to 5 September. Departure from the Northern Highland occurs by 5 September and elsewhere by 15 September.

Nesting Season Distribution: Uncommon and local breeding bird in the Central Plain and Northern Highland. One nest record from the Western Upland (12 June 1976; River Falls, St. Croix County). Confirmed breeding records exist for St. Croix and Polk counties. Green and Janssen (1975) cited inferred breeding records for Chisago and Pine counties, although the golden-winged warbler was referred to as "quite numerous" in Pine County during the nesting season. One was reported from Washington County on 5 July 1970 (Russell 1970). Breeding Bird Survey data (Table 6) suggest that the center of their breeding range is in the Central Plain.

Habitat: Golden-winged warblers appear to be characteristic of secondgrowth deciduous forest in early developmental stages. Data from nearby Barron County (Wisconsin) show that largest densities occur in Deciduous Clear Cuts that are less than 10 years old (9 pairs per 40 ha). This density decreases to < 0.1 pair per 40 ha in mature aspen-maple woods over 40 years old. Breeding golden-winged warblers also use brushy edges of retired agricultural fields, openings in spruce woods, and occasionally Black Spruce-Tamarack Bogs. Golden-winged warblers apparently avoid jack pine habitat; this warbler has yet to be recorded along the Union BBS route (Burnett County) which traverses extensive stands of jack pine forest.

\section{Blue-winged Warbler (Vermivora pinus)}

Status: Regular migrant and nesting species.

Migration: Rare migrant in the Western Upland, virtually absent elsewhere. Most observations consist of birds on or near presumed breeding territories. Spring migrants arrive 15-20 May, becoming most conspicuous 25 May to 5 June. One spring record exists for Burnett County, 20 May 1956 (Southern 1960). Breeding birds disperse early from the breeding areas. The latest fall date is 15 September 1975 (St. Croix County).

Nesting Season Distribution: Rare and local breeding bird in the Western Upland. Green and Janssen (1975) provided the only evidence of confirmed breeding for the Valley (Washington County). Breeding season birds are largely restricted to areas along major river systems, including the Kinnickinnic, Willow, and lower St. Croix. The northern limit of blue-winged warbler breeding range in Wisconsin and Minnesota closely approximates the southern limit of its congener, the golden-winged warbler. As with other regions of limited overlap, hybrids of these species have been observed. Manley Olson observed a hybrid referable to "Brewster's warbler" on 
31 May 1967 in St. Croix County. Olyphant (1973) banded a Brewster's warbler in Washington County on 13 July 1973.

Habitat: In this region, breeding blue-winged warblers are characteristic of extensive stands of mature Lowland Deciduous Forest. Typical vegetation of their breeding habitat includes cottonwood, American elm, and green ash as dominants. Ground-layer vegetation in many situations is usually wood nettle and various grasses. Along the lower Willow River near Hudson, a small group of breeding blue-winged warblers use a savannah-like association of Hill's oak and little bluestem. Brushy fields with invading saplings or scattered trees are also used.

\section{Tennessee Warbler (Vermivora peregrina)}

Status: Regular migrant.

Migration: Common migrant throughout the Valley. Mean date of spring arrival in the Western Upland is 4 May learliest-25 April 1948, Polk County: Robbins 1948c). Arrival in the Northern Highland occurs 10-15 May. Peak spring migration through the Valley occurs 10-25 May. Departure of spring migrants in the Western Upland and Central Plain occurs 25-30 May. In the Northern Highland, stragglers can still be found until 10 June. Several mid-June records that suggest possible breeding exist for the Solon Springs area. However, there are no known breeding records of this bird in Wisconsin.

The Tennessee warbler is among the earliest fall migrants of this family, usually arriving in the Northern Highland 15-20 July, reaching the Central Plain and Western Upland 25 July to 1 August. Peak fall migration occurs 20 August to 15 September. This warbler has departed the Northern Highland by 25 September and elsewhere by 5 October (latest-12 October 1961, St. Croix County).

Habitat: Migrant Tennessee warblers regularly use both deciduous and coniferous woods. Perhaps because of its abundance, this warbler is also regularly encountered in residential shrubbery. At the peak of migration, this species congregates in tall trees in residential areas. Six to 10 males per block is not unusual on a peak day. Most mid-June records have been of birds in Northern Hardwood Forest, Lowland Coniferous Forest, and Black Spruce-Tamarack Bogs.

\section{Orange-crowned Warbler (Vermivora celata)}

Status: Regular migrant.

Migration: Fairly common migrant in the Western Upland and Central Plain, uncommon in the Northern Highland. Spring migrants arrive in the Western Upland 25 April to 1 May (earliest-22 April 1949, Burnett County), reaching the Northern Highland 5-10 May. Peak spring migration occurs 10-20 May and departure by 25 May. Fall migrants arrive 1-5 September. Peak fall migration occurs 20 September to 5 October and departure by 10 October (latest-18 October 1976, St. Croix County). 
Habitat: Most observations of orange-crowned warblers have been in deciduous woods of various early successional stages. Occasional individuals have been observed foraging at the edge of cattail marshes, primarily during spring migration.

\section{Nashville Warbler (Vermivora ruficapilla)}

Status: Regular migrant and nesting species.

Migration: Common migrant throughout the Valley, locally abundant in coniferous habitats of the Northern Highland. Spring migrants begin to arrive in the Western Upland about 1 May, reaching the Northern Highland 10-15 May. Peak spring migration occurs 10-20 May and departure of nonbreeders by 30 May. Fall migration begins with family dispersal in early August: however, the first obvious migratory movements occur after 10 August. The first fall migrants reach the Western Upland about 20 August (earliest-14 August 1963, St. Croix County). Peak fall migration occurs 1-15 September and departure by 5 October (latest-19 October 1968, Pine County).

Nesting Season Distribution: Common breeding bird throughout the Northern Highland; less common and more localized in the Central Plain. No breeding records exist for the Western Upland. Jackson (1943) referred to the Nashville Warbler as "one of the most plentiful Warblers in summer in most of the region" in 1919. Breeding Bird Survey data (Table 6) demon. strate the rapid increase in relative abundance moving northward from the Central Plain.

Habitat: Breeding Nashville warblers have been recorded in a variety of deciduous and coniferous habitats. Greatest use appears to be in coniferous habitats and of these Black Spruce-Tamarack Bogs are probably the most important.

\section{Northern Parula (Parula americana)}

Status: Regular migrant and summer resident.

Migration: Rare and local migrant in the Western Upland and Central Plain, uncommon in the Northern Highland. Spring migrants arrive 5-10 May in the Western Upland, reaching the Northern Highland 10-15 May. Because of the low numbers recorded, no peak dates have been determined. Departure from the southern regions occurs by 20 May. Fall migration is diffuse as very few birds were recorded each year. Available data suggest that the main period of migration extends from 20 August to 20 September.

Nesting Season Distribution: Rare and local summer resident of the Northern Highland. Available records suggest the main part of their breeding range lies north of the St. Croix River in Douglas and Pine counties. The only Breeding Bird Survey route in the Valley that has recorded this species is the Minong route in Douglas County.

Habitat: Although confirmed nest records are lacking, this species un. 
doubtedly breeds in the Valley. Northern parula observations during the breeding season consist of birds using Lowland Coniferous Forest dominated by a mixture of white cedar, balsam fir, and black spruce. Also typical of their breeding habitat is Unsea moss which is used in nest construction.

\section{Yellow Warbler (Dendroica petechia)}

Status: Regular migrant and nesting species.

Migration: Common spring migrant in all regions; fairly common during fall. Spring migrants arrive in the Western Upland 1-5 May and reach the Northern Highland by 10 May. Peak spring abundance occurs 10-20 May. Fall migration begins with dispersal from breeding areas in late July. The first large fall movement of yellow warblers occurs 1-5 August. Peak fall movements are noted 10-25 August and departure by 5 September.

Nesting Season Distribution: Common breeding species throughout the region with confirmed breeding records from all counties. Jackson (1943) reported that yellow warblers were uncommon breeding birds at the headwaters of the St. Croix River in 1919. Breeding Bird Survey data (Table 6) suggest that the center of yellow warbler abundance in the Valley is in the Central Plain. Goddard (1972) reported a breeding density of 3.4 pairs per 40 ha in the Kinnickinnic River Valley, Pierce County.

Habitat: This warbler appears to use a wide range of habitats, including second-growth deciduous and coniferous woodland, Deciduous Clear Cuts, Black Spruce-Tamarack Bogs, Alder Thicket, Shrub Carr, and edge of various natural basin wetlands. Although seemingly ubiquitous in breeding habitat use, it appears that the yellow warbler demonstrates a strong preference for wetland and wetland-associated habitats.

\section{Magnolia Warbler (Dendroica magnolia)}

Status: Regular migrant and summer resident.

Migration: Fairly common migrant in all regions. Spring migrants arrive in the Western Upland 5-10 May (earliest-1 May 1969, Washington County) and reach the Northern Highland about 15 May. Peak spring migration occurs 15-25 May but stragglers remain until 1 June. Fall migrants arrive in the Northern Highland 15-20 August and the Western Upland about 20 August (earliest-15 August 1976, Washington County). Peak fall migration occurs 5-20 September and departure by 1 October (latest-21 October 1955, Polk County; Foster 1956).

Nesting Season Distribution: Rare and local summer resident, restricted to the Northern Highland. Several summer records (16 June 1973, 28 June 1974, and 12 June 1977 from along the St. Croix River in Douglas County, and 10 June 1977 along the St. Croix in Pine County) suggest the possibility of nesting. Bernard (1967) considered the magnolia warbler a rare summer resident in Douglas County, but provided no evidence of nests. 
Habitat: Migrant magnolia warblers occupy a wide range of both deciduous and coniferous habitats. This species is most frequently encountered during migration in early successional stages of northern upland deciduous forest and in Deciduous Clear Cuts. My observations of this warbler during the breeding season have been confined to extensive stands of Black Spruce-Tamarack Bog. This habitat type appears to be used extensively for nesting within their normal breeding range in northern Minnesota and Wisconsin.

\section{Cape May Warbler (Dendroica tigrina)}

Status: Regular migrant, one summer record.

Migration: Uncommon to rare migrant in the Western Upland and Central Plain, uncommon to locally common migrant in the Northern Highland. Spring migrants arrive in the Western Upland 5-10 May, reaching the Northern Highland about 15 May. During spring migration, Cape May warblers are most regularly observed 15-25 May and have departed by 1 June. Robbins (1973) provided the only summer record for the Valley, a singing male $1.6 \mathrm{~km}$ north of Gordon, Douglas County, on 16 June 1971. Fall migration begins in mid-August with first arrivals in the Central Plain about 20 August. During fall they are regularly encountered from 25 August to 10 September and depart by 25 September (latest-29 September 1965, Washington County).

Habitat: Migrant Cape May warblers use various age classes of coniferous habitats and early successional stage deciduous habitats. In residential areas, this species is also attracted to blossoming apple trees and ornamental spruces. Robbins (1973) described the habitat of a group of nesting Cape May warblers along the Brule River as black spruce. The area that Robbins described is $8.0 \mathrm{~km}$ north of Solon Springs, Douglas County, and within $4.8 \mathrm{~km}$ of the St. Croix River watershed. Because extensive stands of similar black spruce habitat exist along the St. Croix near Solon Springs, I would expect that additional birds could be located. However, to date I have been unsuccessful in finding this warbler during the breeding season along the St. Croix River.

\section{Black-throated Blue Warbler (Dendroica caerulescens)}

Status: Regular migrant, occasional summer resident.

Migration: Rare migrant throughout the Valley. Most records are from directly adjacent to the St. Croix River. Spring migrants arrive 5-10 May (earliest-2 May 1972, Washington County) and have departed by 25 May. Fall records tend to indicate that this warbler occurs more commonly during that period. Fall migrants arrive 30 August to 5 September. Records indicate that peak fall numbers occur 15-25 September and departure by 30 September (latest-21 October 1961, Polk County).

Nesting Season Distribution: The only evidence of summer residence is provided by Green and Janssen (1975) who reported the most southerly summer 
records in Minnesota are from "northern Pine County." I have obtained no summer records of this bird within the Valley in Minnesota or Wisconsin. However, during 5-30 June 1971, I regularly observed three pairs of blackthroated blue warblers in Bayfield County about $24 \mathrm{~km}$ east of Solon Springs. These observations suggest that breeding black-throated blue warblers may also occur in suitable habitat along the northern reaches of the St. Croix River.

Habitat: During migration, this warbler is most common in wet or mesic deciduous forest sites. I have only one record from xeric Southern Deciduous Forest that was dominated by red oak. Observations of black-throated blue warblers during the breeding season in Bayfield County, Wisconsin, were in extensive stands of mature maple-basswood-aspen forest.

\section{Yellow-rumped Warbler (Dendroica coronata)}

Status: Regular migrant and nesting species, occasional winter resident.

Migration: Abundant migrant throughout the Valley. The yellow-rumped warbler is the most numerous warbler in this region. Spring migrants arrive in the Western Upland about 5 April (earliest-21 March 1975, Pierce County; 24 March 1963, St. Croix Countyl. Migrants reach the Northern Highland 10-15 April. Peak spring migration through the Valley extends from 20 April to 10 May. Departure from nonbreeding areas occurs by 15 May (latest-24 May 1971, Washington County). Fall migration begins in the Northern Highland 15-20 August; however, the first fall migrants do not reach the Western Upland until 10 September. Peak fall migration occurs 20 September to 5 October. Departure from the Northern Highland occurs by 15 October; 1 November is the usual departure date elsewhere. Occasional stragglers remain in the Western Upland through November. Late dates include 30 November 1975, Pierce County and 3 December 1961 , St. Croix County.

Nesting Season Distribution: Rare and local breeding bird, restricted primarily to the Northern Highland. Green and Janssen (1975) showed that the breeding range of this warbler extended into northwestern Pine County. Jackson (1943) did not record breeding season yellow-rumped warblers in the Valley during 1919. Breeding Bird Survey data (Table 6) show that a limited number of yellow-rumped warblers occur along the route of the Minong BBS transect in Douglas County.

On 24 June 1974 and 11 June 1977, I recorded singing yellow-rumped warblers along the St. Croix River in Sec. 23, T. 43 N., R. 14 W., Douglas County, and one singing male was recorded along the St. Croix River in Pine County at the U.S. Highway 77 crossing $4.8 \mathrm{~km}$ west of Danbury. Singing and behavioral activities suggested nesting, although nests or young were not observed.

Winter: The only record of an overwintering yellow-rumped warbler is that of one bird remaining at a feeder near River Falls, St. Croix County, during the 1960-61 winter (Faanes and Goddard 1976). Two additional early winter records exist from the Afton CBC: 1 January 1970 (St. Croix County) and 
1 January 1975 (Washington County). It is not known if these birds remained throughout the winter.

Habitat: During migration, this warbler is ubiquitous, occurring in essentially all available habitats. Breeding season records include birds from extensive stands of Lowland Coniferous Forest, dominated by white spruce, from Black Spruce-Tamarack Bogs, Jack Pine Barren, and areas of mature white pine. Both habitats are used extensively by nesting yellow-rumped warblers within their normal breeding range in northern Minnesota and Wisconsin.

\section{Black-throated Green Warbler (Dendroica virens)}

Status: Regular migrant and nesting species.

Migration: Uncommon migrant throughout the Valley, locally common in the Northern Highland. Spring migrants arrive in the Western Upland 5-10 May, reaching the Northern Highland 10-15 May. Peak spring migration occurs 15-25 May and nonbreeders have departed by 30 May. Fall migration begins in the Northern Highland 15-20 August and the first migrants reach the Western Upland 25-30 August. Peak fall migration occurs 5-20 September and departure by 5 October (latest-7 October 1973, St. Croix County).

Nesting Season Distribution: Uncommon breeding bird in the Northern Highland. Rare and local in southern Pine, Burnett, and northern Polk and Chisago Counties. Jackson (1943) reported this warbler as "not uncommon" at Solon Springs, Douglas County. On BBS transects (Table 6) blackthroated green warblers have been recorded only on the Minong route, Douglas County. This warbler was recorded on 9 June 1973 in Chisago County (Longley 1973b), but no evidence of nesting was obtained.

Habitat: Mature Northern Hardwood Forest dominated by sugar maple, basswood, and trembling aspen is used extensively. The large expanses of Lowland Coniferous Forest, primarily adjacent to the upper St. Croix River, are also important.

\section{Cerulean Warbler (Dendroica cerulea)}

Status: Regular migrant and nesting species.

Migration: Rare spring and fall migrant, restricted primarily to the Western Upland and a small region of the Central Plain. Spring migrants begin to arrive 10-15 May. Most observations are after 15 May and are probably of birds on breeding territories. Data are too few to establish fall migration periods. The latest date available is 16 August 1974 in St. Croix County.

Nesting Season Distribution: Rare and local breeding bird. Confirmed nest records exist only for St. Croix County. On 23 June 1976, I observed adults feeding two young in the nest along the Willow River near Hudson (T. 29 N., R. 19 W.). Cerulean warblers occur regularly only in the lower reaches of the Kinnickinnic River (Pierce County) and Willow River (St. Croix County) and 
near Afton State Park (Washington County). Occasional breeding season records have been obtained at the mouth of the Apple River (St. Croix County) and from lowland forest at Marine-on-St. Croix (Washington County). Records away from the typical range of this warbler in the Valley include two singing males on 2 June 1968 at Franconia, Chisago County, one in Chisago County on 6 June 1971, and one male near Range, Polk County, on 15 June 1968.

Habitat: Breeding season observations of this warbler have been restricted to Lowland Deciduous Forest. Predominant vegetation of these areas include mature stands of American elm, cottonwood, and green ash.

\section{Blackburnian Warbler (Dendroica fusca)}

Status: Regular migrant and nesting species.

Migration: Fairly common migrant in the Western Upland and Central Plain, common in the Northern Highland. Spring migrants arrive 5-10 May, reaching the Northern Highland 10-12 May. Peak spring migration occurs 15-25 May and departure from nonbreeding areas by 30 May. Jackson (1943) considered this warbler "abundant" at St. Croix Falls (Polk County) 21-25 May 1919. Fall migration begins 10-15 August and the first birds reach the Western Upland about 20 August. Peak fall migration occurs $5-15$ September and birds depart by 25 September.

Nesting Season Distribution: Uncommon breeding bird, restricted to the Northern Highland. Breeding season records exist for Burnett, Douglas, and Pine counties. The only confirmed nest records are from Pine (Green and Janssen 1975) and Douglas (Chambers 1944) counties. However, it undoubtedly nests elsewhere in the Northern Highland. Jackson (1943) reported that courting Blackburnian warblers were observed at St. Croix Falls on 24 May 1919. He noted that "although no nests were discovered . . . the environment is favorable for nesting." Breeding Bird Survey data (Table 6) indicate that this bird occurs in relatively low densities during the breeding season in the Northern Highland.

Habitat: The Blackburnian warbler is characteristic of northern coniferous forests. Territorial birds are encountered most regularly in large tracts of Lowland Coniferous Forest dominated by black spruce, white cedar, and hemlock. Breeding birds also use Black Spruce-Tamarack Bogs and white pine forest where remnants still exist.

\section{Chestnut-sided Warbler (Dendroica pensylvanica)}

Status: Regular migrant and nesting species.

Migration: Common migrant throughout the Valley. The mean date of spring arrival in the Western Upland is 8 May (earliest-2 May 1974, Pierce County) and arrival in the Northern Highland by 12 May. Peak migration occurs 10-25 May and birds have departed nonbreeding areas by 30 May. Fall migration begins in the Northern Highland 5-10 August with dispersal 
of young, and the first migrants reach the Western Upland 15-20 August. Peak migration occurs 1-15 September. Departure from the Northern Highland occurs 15-20 September and elsewhere by 1 October (latest-5 October 1973, St. Croix County).

Nesting Season Distribution: Common breeding bird in the Northern Highland and that part of the Central Plain north of St. Croix Falls and Taylor's Falls. South of that line, they are uncommon and local, and rare and local in the Western Upland. Green and Janssen (1975) showed that the breeding range of this warbler extended through the three Minnesota counties. On 26 June 1979, I heard and saw territorial males $4.8 \mathrm{~km}$ west of Taylor's Falls, Chisago County. Although nests or young were not observed, I have no doubt they nested in this area.

Nests or young have been recorded in all subject Wisconsin counties except Pierce. An area near the Cylon Marsh Wildlife Area (Sec. 15, T. 31 N., R. 16 W.) and at the mouth of the Apple River (Sec. 20, T. 31 N., R. 19 W.), St. Croix County, are the most southerly locations of regular occurrence. Jackson (1943) recorded this warbler only "occasionally" in the Northern Highland near Solon Springs in 1919, but BBS data (Table 6) show that breeding chestnut-sided warblers occur commonly throughout the Valley and that largest densities are in the Northern Highland.

Habitat: Early successional stages of deciduous and coniferous habitats are used for nesting. Deciduous Clear Cuts that are predominantly aspen support the greatest density of breeding chestnut-sided warblers. Northern Hardwood Forest that is dominated by maple-basswood-aspen is also important. Recent attempts by State wildlife agencies to retard vegetational succession by clear-cutting or selectively logging mature deciduous forest are beneficial for this warbler.

\section{Bay-breasted Warbler (Dendroica castanea)}

Status: Regular migrant.

Migration: Uncommon to rare spring migrant in the Western Upland and Central Plain; fairly common in the Northern Highland. Common fall migrant throughout the Valley. Spring migrants arrive in the Western Upland 8-12 May, reaching the Northern Highland about 15 May. Peak migration occurs 15-25 May and departure by 1 June. Jackson (1943) reported that the collection of a female bay-breasted warbler at Danbury, Douglas County, on 27 May 1919 was the only spring record obtained in northwestern Wisconsin that year. Fall migrants arrive in the Northern Highland in late July, reaching the Western Upland 10-15 August. Peak fall migration occurs 1-20 September. Departure from the Northern Highland occurs 20-25 September and elsewhere by 1 October (latest-19 October 1968, Chisago County).

Habitat: Bay-breasted warblers occupy a wide range of deciduous and coniferous habitats. In the Northern Highland they are most regularly observed in Lowland Coniferous Forest or Black Spruce-Tamarack Bog. 


\section{Blackpoll Warbler (Dendroica striata)}

Status: Regular migrant.

Migration: Common migrant throughout the Valley. Spring migrants arrive in the Western Upland 5-10 May (earliest-30 April 1967; 1 May 1969. Washington County) and the Northern Highland 10-15 May. Peak spring migration occurs 15-25 May and departure is by 30 May (latest-2 June 1970, Washington County). Fall migrants arrive in the Northern Highland 10-15 August and reach the Western Upland 15-20 August. Peak fall migration occurs 30 August to 20 September and departure 25-30 September.

Habitat: Although both deciduous and coniferous forest habitats are regularly used, this warbler is the most common in mature deciduous forest.

\section{Pine Warbler (Dendroica pinus)}

Status: Regular migrant and nesting species.

Migration: Uncommon to rare migrant throughout the Valley. Jackson (1943) found this warbler not as plentiful as anticipated in 1919. However, they were considered "common" at Danbury, Burnett County, 27-30 May 1919. Spring migrants arrive in the Western Upland 1-5 May and the Northern Highland 5-10 May. This species is most frequently encountered 10-20 May. Departure from nonbreeding areas occurs by 25 May. Fall migration begins in the Northern Highland 10-15 August and the first birds reach the Western Upland 20-30 August. This species is most frequently encountered 1-15 September and they have departed by 1 October.

Nesting Season Distribution: Uncommon breeding species in the Northern Highland, rare and local in the Central Plain. Breeding Bird Survey data (Table 6) also suggest that this species is in the Western Upland during the nesting season. Although breeding season records exist for all areas except Pierce and Washington counties, confirmed nest records exist only for Pine County. Territorial birds were recorded in Chisago County during the summers of 1973-74 and 1976. The only location of regular occurrence in St. Croix County is near Burkhardt (Sec. 3, T. 29 N., R. 19 W.).

Habitat: Characteristic nesting species of remnant white pine forest. Although regularly recorded in Jack Pine Barrens, Breeding Bird Survey data for the Union transect (Burnett County) suggest that low densities occur in that habitat.

\section{Palm Warbler (Dendroica palmarum)}

Status: Regular migrant, probable nesting species.

Migration: Abundant migrant throughout the Valley, probably second only to the yellow-rumped warbler in overall abundance. Spring migrants arrive in the Western Upland 25 April to 1 May, reaching the Northern Highland 1-5 May. Peak migration occurs 5-15 May and departure by 25 May. A singing male in Chisago County on 4 June 1968 was undoubtedly a very late 
migrant. Fall migrants arrive in the Northern Highland 20-25 August and the Central Plain 25 August to 5 September. Peak fall migration occurs 10-25 September and birds depart by 10 October (latest-25 October 1968 , Chisago County).

Nesting Season Distribution: This species probably nests in Douglas County (S. D. Robbins, personal communication). On 27 June 1966, Robbins heard a singing male palm warbler in a bog in Sec. 35, T. 43 N., R. 12 W. On 26 June 1974 a male was heard in Sec. 23, T. 43 N., R. 12 W. On the same date another male palm warbler was recorded in a large open bog $6.4 \mathrm{~km}$ north of Moose Junction (T. 44 N., R. 14 W.).

Habitat: In the Western Upland and Central Plain, palm warblers occupy medium-aged deciduous forest extensively. Alder Thicket and Shrub Carr are also important. In the Northern Highland, extensive use is made of Lowland Coniferous Forest, Black Spruce-Tamarack Bogs, and sedge meadow. Nesting season records are of birds in open Black Spruce-Tamarack Bogs.

\section{Ovenbird (Seiurus aurocapillus)}

Status: Regular migrant and nesting species.

Migration: Common migrant throughout the Valley. Spring migrants arrive in the Western Upland about 1 May and the Northern Highland 5-10 May. Peak spring migration occurs 10-20 May. Departure from nonbreeding areas of the Western Upland occurs by 25 May. Peak fall migration is 1 September (Northern Highland) to 10 September (Western Upland) and departure is by 1 October.

Nesting Season Distribution: Common to locally abundant breeding bird in the Northern Highland and Central Plain. Uncommon and local in the Western Upland. Breeding Bird Survey data (Table 6) indicate that this warbler occurs in greatest numbers in the Northern Highland and Central Plain. Jackson (1943) referred to the ovenbird as the characteristic and often dominant breeding bird in heavier deciduous forest $1=$ mature Northern Hardwood). Goddard (1972) reported the ovenbird was the most abundant breeding warbler in the Lower Kinnickinnic River Valley, Pierce County.

Habitat: Characteristic nesting species of mature Northern Hardwood Forest, where the predominant tree species include sugar maple, basswood, trembling aspen, and white birch. In the Western Upland, breeding ovenbirds are associated with red oak-Hill's oak forest. Remnant stands of mixed red pine and white pine are regularly used in the northern regions.

\section{Northern Waterthrush (Seiurus noveboracensis)}

Status: Regular migrant and nesting species.

Migration: Fairly common migrant in the Western Upland and Central Plain, locally common in the Northern Highland. Spring migrants arrive 1-5 May, reaching the Northern Highland 5-10 May. Peak migration occurs 10-20 May and departure from nonbreeding areas is by 30 May. Fall 
migrants arrive in the Northern Highland about 5 August, reaching the Western Upland 20-25 August (earliest-12 August 1962, St. Croix County). Peak fall migration occurs 25 August to 10 September and departure by 30 September.

Nesting Season Distribution: Rare and local breeding species, occurring primarily in the Northern Highland. Most observations of nesting season northern waterthrushes have been in habitats along and adjacent to the St. Croix River in Douglas, Burnett, and Pine counties. Breeding Bird Survey data show the low breeding density of this species in the Valley. Goddard (1972) reported a northern waterthrush during the breeding season along the Kinnickinnic River, Pierce County, in June 1971. If correct, that record would extend the probable breeding range of this species at least $160 \mathrm{~km}$ south. The lack of proper habitat, plus the population of Louisiana waterthrush along the river, render that record suspect.

Habitat: This species uses a narrow range of wet habitats in the Northern Highland. Primary breeding habitat includes Lowland Coniferous Forest, Alder Thicket, and Northern Sedge Meadow that is becoming invaded with various shrubs including smooth alder and gray dogwood. During migration in the Western Upland and Central Plain, Lowland Deciduous Forest, Northern Hardwood Forest, and Deciduous Clear Cuts are used extensively, as are shorelines of lakes and streams.

\section{Louisiana Waterthrush (Seiurus motacilla)}

Status: Regular migrant and nesting species.

Migration: Rare spring migrant in the Western Upland and Central Plain. Records in the Central Plain are restricted to areas south of St. Croix Falls and Taylor's Falls. No well-defined pattern of spring migration can be established. Most birds observed appear to be on established breeding territories. Most spring individuals occur 10-30 May (earliest-27 April 1964 [Soulen 1965], 2 May 1948, and 3 May 1966; Washington County). Fall migration is early and diffuse (latest-23 August 1974, Chisago County; 11 September 1972, St. Croix County).

Nesting Season Distribution: Rare and local nesting species of the Western Upland and Central Plain. Confirmed breeding records exist for Chisago (Green and Janssen 1975), Washington, and St. Croix counties. Breeding season birds have also been recorded in Pierce and Polk counties; however, nest records are lacking.

Probably the best-known breeding area in the Valley for Louisiana waterthrush is along Lawrence Creek near Franconia, Chisago County. Longley $(1973 b)$ described the first known breeding record of this bird at that location, when a nest containing two young cowbirds, one young Louisiana waterthrush, and one addled egg was found near Franconia on 9 June 1973. In June 1968 Longley (1973b) recorded six singing males at this same locality. One Louisiana waterthrush was also recorded at that location in 1974-76 and a nest was found in 1975 .

Another well-known nesting area is along the lower Willow River near the 
Trout Brook Road bridge at Hudson, St. Croix County. At that location, Louisiana waterthrush has been recorded in the breeding season intermittently since 1960 . On 3 June 1974 I recorded singing males at four locations along a $300-\mathrm{m}$ reach of this stream. Returning on 5 June 1975, I located two singing males and found one nest containing three eggs; their outcome is unknown.

Elsewhere, records from Washington County include one nest at Stillwater on 10 July 1943 (Chambers 1944) and a nest containing five young on 17 June 1945 (Lupient 1945). Roberts (1938) described the observation of a nest and young along the St. Croix River below Taylor's Falls, Chisago County, on 2-4 July 1927. Goddard (1972) reported this species during June 1971 along the Lower Kinnickinnic River, Pierce County. In the area near the mouth of that river, two to three singing males have been recorded yearly in June 1973-78, but no nest has been found.

Habitat: Rich stands of Lowland Deciduous Forest along fast-moving streams. The St. Croix County nest was located beneath an overhanging root of American elm. less than $1 \mathrm{~m}$ from water's edge.

\section{Kentucky Warbler (Oporornis formosus)}

Status: Casual, two records.

Record: S. D. Robbins observed a male Kentucky warbler near Roberts, St. Croix County, on 28 May 1963 (Faanes and Goddard 1976). This observation represents the most northerly record of this warbler in Wisconsin. Glassel (1977) described the observation of a singing male Kentucky warbler on 17 June 1977 at Afton State Park, Washington County. The bird remained in the area at least until 19 June 1977.

\section{Connecticut Warbler (Oporornis agilis)}

Status: Regular migrant and nesting species.

Migration: Rare spring and uncommon fall migrant throughout the Valley. Spring migrants arrive in the Western Upland 15-20 May (earliest-4 May 1974. Pierce County), and reach the Northern Highland about 25 May. During spring they are most frequently observed 25 May to 5 June and depart by 10 June. Fall migrants arrive 15-20 August in the Northern Highland and 20-25 August in the Western Upland. Peak fall migration occurs 5-15 September and they depart by 25 September. Roberts (1938) mentioned the observation of "several" Connecticut warblers in Pine County during the first week of October 1929.

Nesting Season Distribution: Rare and local during the nesting season. Gromme (1941) described the only confirmed breeding of this warbler in the Valley; a nest containing four young on 7 July 1941, near Gordon, Douglas County (T. 43 N., R. 13 W.). Green and Janssen (1975) showed that the nesting range of this warbler in Minnesota reached northern Pine County. Breeding Bird Survey data (Table 6) suggest that a fairly large breeding population exists in southern Douglas County (Sec. 11, 12, 13, 14, T. 43 N., 
R. 12 W.; Robbins 1974a). Another population is known to occur in northwestern Burnett County near Grantsburg.

Habitat: Bent (1953) described the breeding habitat of the Connecticut warbler as consisting of tamarack bogs or wet coniferous forest. However, Robbins (1974a) reported this warbler in fairly large densities in monotypic stands of jack pine. Further description of this habitat indicates the trees were 4-9 $\mathrm{m}$ high and had well-developed lower branches. Trees $<4.6 \mathrm{~m}$ tall or those with a scarcity of lower branches were not used by breeding Connecticut warblers. Robbins' observation of nesting in jack pine is further substantiated by recent (1974-78) records from the Union BBS transect, Burnett County. The habitat along this route also consists of large tracts of jack pine, and Connecticut warblers have been found regularly there.

\section{Mourning Warbler (Oporornis philadelphia)}

Status: Regular migrant and nesting species.

Migration: Fairly common migrant throughout the Valley. Spring migrants arrive in the Western Upland 10-15 May and reach the Northern Highland 15-20 May. Peak spring migration occurs 25 May to 5 June and departure from nonbreeding areas by 10 June. Fall migrants arrive in the Western Upland 20-25 August. Peak fall migration through the Valley occurs 5-15 September and departure by 25 September (latest-29 September 1965, Washington County).

Nesting Season Distribution: Fairly common (locally common) breeding bird in the Northern Highland and the northern half of the Central Plain. Elsewhere, the mourning warbler is uncommon to rare during the nesting season. A nest with young observed in Washington County on 11 and 13 July 1975 (Eckert 1975) represents the southernmost breeding record in the Valley. Breeding Bird Survey data (Table 6) also suggest that the mourning warbler breeding population increases with latitude through the Valley.

Habitat: Characteristic breeding habitat of the mourning warbler includes Northern Hardwood Forest and Deciduous Clear Cuts. Primary nesting habitat of this warbler appears to be areas of dense understory in mature stands of deciduous forest, such as those resulting from openings in the overstory that allow ample sunlight to penetrate. The edge between medium-aged aspen forest and open fields or highway rights-of-way are also important habitats. I have not recorded this warbler in coniferous habitats during the breeding season.

\section{Common Yellowthroat (Geothlypis trichas)}

Status: Regular migrant and nesting species.

Migration: Common migrant throughout the Valley. Spring migrants arrive in the Western Upland 1-5 May and the Northern Highland about 10 May. Peak spring migration occurs 10-20 May. Fall migration begins about 15 August. Peak fall migration through the Valley occurs 5-20 September and departure by 5 October (latest-17 October 1955, Polk County). 
Nesting Season Distribution: Abundant and well-distributed breeding bird in all regions. Confirmed nest records have been obtained from all counties. Goddard (1972) reported that the common yellowthroat was the second most abundant breeding warbler in the Kinnickinnic River Valley, Pierce County. Breeding Bird Survey data (Table 6) suggest that the common yellowthroat is the most obvious, if not the most abundant, breeding warbler in the Valley. The greatest relative abundance occurs in the Northern Highland and in northern areas of the Central Plain.

Habitat: The common yellowthroat is nearly unlimited in its choice of nesting habitat. Jackson (1943) found this warbler in "damp brushy woodland." In the Western Upland, common yellowthroats are most abundant in small patches of mixed willow and cottonwood associated with streams or rivers. In the Central Plain, extensive use is made of the cattail-bulrush vegetation associated with seasonally and semipermanently flooded wetlands; Shrub Carr and sedge meadow are also important. In the Northern Highland, this warbler uses Alder Thickets, Northern Sedge Meadows, and Forest Bordered Lakes. Tamarack bogs and Lowland Coniferous Forest are also important. Use of upland habitats include dry upland fields and brushy edge areas.

\section{Yellow-breasted Chat (Icteria virens)}

Status: Casual migrant and summer resident.

Migration: There are two spring records from St. Croix County: 6 May 1964 and 18 May 1962. Both observations were made along Trout Brook Road near Hudson. One fall record (22-29 September 1948) exists for St. Croix Falls, Polk County (Robbins 1949).

Nesting Season Distribution: S. D. Robbins observed singing male yellowbreasted chats near Hudson and Burkhardt, St. Croix County, on 17 June 1961, 21 June 1963, and 30 June 1964. The habitat associated with these birds consisted of various shrubby plants at the border of agricultural fields and (one bird) the edge of a retired hayfield. These habitats are similar to typical breeding habitat within their normal range. Thus, it is likely at that date that these were males defending territories or at least advertising for a mate.

Habitat: This species is most frequently encountered in the Old Field Community and brushy edges of Southern Deciduous Forest.

\section{Hooded Warbler (Wilsonia citrina)}

Status: Casual, two spring records.

Records: S. D. Robbins observed a singing male hooded warbler at the entrance to Birkmose Park in Hudson, St. Croix County, on 29 May 1963 (Faanes and Goddard 1976). A male hooded warbler was banded and photographed in Washington County on 2 June 1962 (Olyphant 1962). 


\section{Wilson's Warbler (Wilsonia pusilla)}

Status: Regular migrant.

Migration: Fairly common (locally common) migrant throughout the Valley. Spring migrants arrive in the Western Upland about 10 May learliest4 May 1966, Washington County) and reach the Northern Highland from 10-15 May. Peak spring migration occurs 15-25 May and departure is by 1 June. Fall migrants arrive in the Northern Highland 10-15 August and the Western Upland about 20 August. Peak fall migration occurs 25 August to 10 September and departure is by 25 September (latest-27 September 1967, Washington County).

Habitat: Wilson's warbler uses a variety of deciduous and coniferous habitats during migration. Although no single habitat is of major importance, this species is most frequently observed in brushy fencerows, Deciduous Clear Cuts, and young to medium-aged Northern Hardwood Forest dominated by trembling aspen and white birch.

\section{Canada Warbler (Wilsonia canadensis)}

Status: Regular migrant and summer resident.

Migration: Uncommon migrant throughout the Valley. The Canada warbler is among the latest arriving warblers during spring migration. The first birds reach the Western Upland 12-15 May and the Northern Highland 15-20 May. Peak spring migration occurs 20-30 May and departure from nonbreeding areas by 30 May (latest-2 June 1970. Washington County). The first fall migrants arrive in the Western Upland 5-10 August. Peak fall migration occurs 15 August to 5 September and departure by 15 September (latest-29 September 1967, Washington County).

Nesting Season Distribution: Rare and local during the breeding season. apparently restricted to the Northern Highland. Breeding Bird Survey data (Table 6) also suggest restriction to the Northern Highland. The breeding range of this warbler in the Minnesota counties is known to include only northern Pine County (Green and Janssen 1975).

Habitat: Primarily encountered along the edge of Northern Hardwood Forest and in Lowland Coniferous Forest during the nesting season. My observations of this bird's breeding habitat suggests that brushy understory associated with Northern Hardwood Forest is probably most regularly used. Deciduous Clear Cuts in the Northern Highland receive moderate use as does the brushy edge between aspen forest and adjacent open areas.

\section{American Redstart (Setophaga ruticilla)}

Status: Regular migrant and nesting species.

Migration: Common (locally abundant) migrant throughout the Valley. Spring migrants arrive in the Western Upland 1-5 May and reach the Northern Highland 5-10 May. Peak spring migratio.r occurs 10-25 May. 
During 1919, Jackson (1943) reported that American redstarts were "the commonest of the warblers" at St. Croix Falls, Polk County, and he found them "abundant" in timber along the St. Croix River. Fall migration begins 5-10 August in the Northern Highland and 20-25 August elsewhere. Peak fall migration occurs 25 August to 15 September and departure is by 5 October (latest-13 October 1966, Washington County).

Nesting Season Distribution: Common nesting species throughout the Valley. Locally abundant in the Western Upland and Central Plain, in areas associated with the mouths of major streams. Goddard (1972) reported a density of 3.9 pairs per 40 ha in the lower Kinnickinnic River Valley, Pierce County. However, his study area was primarily upland deciduous forest, which is not preferred habitat of breeding American redstarts. Breeding Bird Survey data (Table 6) suggest that highest breeding densities occur in the Central Plain and Northern Highland. Unfortunately, this route of survey does not traverse important American redstart habitat directly adjacent to the St. Croix River and its tributaries in the Western Upland.

Habitat: Characteristic breeding bird of Lowland Deciduous Forest in the Western Upland and Central Plain. Vegetation of these areas includes American elm, box elder, green ash, and basswood. Important upland habitat in the Northern Highland includes medium-aged to mature Northern Hardwood Forest that is dominated by basswood, maple, big-toothed aspen, and white birch. Use of coniferous habitats by nesting American redstarts is very light.

\section{FAMILY PLOCEIDAE: Weaver Finches}

\section{House Sparrow (Passer domesticus)}

Status: Introduced permanent resident.

Distribution: Common to locally abundant resident throughout the Valley. The largest concentrations of house sparrows occur in residential areas and other sites of human habitation, including rural residential developments and farms. This species is less numerous and more localized in heavily forested habitats away from the influence of humans.

Habitat: Closely related to areas of human settlement including houses, office buildings, feedmills, railroad tracks, farmyards, feedlots, and pastures.

FAMILY ICTERIDAE: Meadowlarks, Blackbirds, and Orioles

\section{Bobolink (Dolichonyx oryzivorus)}

Status: Regular migrant and nesting species.

Migration: Common to locally abundant migrant in Western Upland and Central Plain, uncommon and local in the Northern Highland. Spring mi- 
grants arrive 25 April to 1 May, reaching northern areas by 10 May. Peak spring migration occurs 10-20 May. Fall migration begins in late July in the Northern Highland and 10-15 August elsewhere. Peak abundance occurs 20-30 August and departure from the Northern Highland by 20 August and 15 September elsewhere.

Nesting Season Distribution: Common to locally abundant nesting species in Western Upland and Central Plain. Rare to uncommon and local in the Northern Highland. Breeding Bird Survey data (Table 7) indicate that a uniformly large breeding population occurs in the Western Upland and Central Plain. Documented breeding records exist for Pierce, St. Croix, and Polk counties. There are inferred breeding records for the remainder of the region. In Douglas County, Bernard (1967) referred to the bobolink as a "common summer resident." Jackson (1943) found this species to be "distributed . . . where meadow environment suitable for them prevails"; however, he provided no data for the Valley.

Habitat: Characteristic species of grassland communities including retired cropland, alfalfa fields, tame pasture, Managed Grasslands, and remnant prairies. Occasionally found using Northern Sedge Meadow and Shrub Carr; however, these habitats apparently receive higher use during migration.

\section{Eastern Meadowlark (Sturnella magna)}

Status: Regular migrant and nesting species, casual in winter.

Migration: Fairly common migrant east of the St. Croix River, uncommon west of the river. Spring migrants arrive 5-15 March, reaching peak abundance 1-15 April. Fall migration begins in early September in the Northern Highland and by 10 September elsewhere. Peak abundance occurs 25 September to 15 October and departure by 1 November.

Nesting Season Distribution: Fairly common nesting species throughout the Valley; most numerous in eastern segments of the Western Upland and

Table 7. Mean number of bobolinks, meadowlarks and blackbirds recorded on western Wisconsin Breeding Bird Survey transects, 1966-78.

\begin{tabular}{lccccc} 
& $\begin{array}{c}\text { Western } \\
\text { Upland }\end{array}$ & \multicolumn{2}{c}{ Central Plain } & \multicolumn{2}{c}{ Northern Highland } \\
& $\begin{array}{l}\text { Hudson } \\
\text { Species }\end{array}$ & Dresser & Loraine & Union & Minong \\
Bobolink & 31.0 & 30.7 & 37.0 & 0.1 & 0.5 \\
Eastern meadowlark & 3.4 & 10.7 & 22.7 & 0.0 & 0.4 \\
Western meadowlark & 133.7 & 73.7 & 32.2 & 0.1 & 0.2 \\
Yellow-headed blackbird & 4.1 & 3.4 & 1.2 & 0.1 & 0.5 \\
Red-winged blackbird & 50.0 & 184.4 & 203.2 & 8.7 & 36.0 \\
Northern oriole & 7.3 & 16.3 & 12.2 & 3.7 & 8.3 \\
Brewer's blackbird & 0.0 & 0.6 & 1.7 & 0.2 & 2.7 \\
Common grackle & 43.8 & 84.6 & 61.2 & 0.4 & 10.5 \\
Brown-headed cowbird & 11.2 & 36.1 & 33.5 & 24.4 & 37.9
\end{tabular}


Central Plain. Documented nesting records exist from St. Croix and Pierce counties. The eastern meadowlark probably nests in the remainder of the Valley. Breeding Bird Survey data (Table 7) demonstrate a marked increase in relative abundance moving eastward from the St. Croix River. These population indices range from an average of 3.4 per year on the Hudson BBS (St. Croix County), to 22.7 per year on the Loraine BBS (Polk County).

Winter: Several winter records exist for this species, primarily from Washington County. These records include one on the St. Paul Suburban CBC 30 December 1961 and two on this count 30 December 1972. There are two winter records from Wisconsin: three birds that I netted on 16 January 1975 in Pierce County and one bird near Deronda, Polk County, during the 1947-48 winter (Robbins 1948b).

Habitat: Eastern meadowlarks occupy a variety of grassland habitats including domestic hayfields, retired croplands, remnants of oak savannah habitats, overgrazed pasture, Old Field Communities, and drier portions of Shrub Carr wetlands.

\section{Western Meadowlark (Sturnella neglecta)}

Status: Regular migrant, nesting species, and winter resident.

Migration: Common to abundant migrant in the Western Upland and Central Plain, fairly common in the Northern Highland. Spring migrants arrive in the Western Upland 5-10 March and reach the Northern Highland 25 March to 5 April. Peak abundance occurs 25 March to 15 April. Fall migration begins in mid-August in the Northern Highland and by 1 September elsewhere. Peak abundance occurs 20 September to 20 October and departure by 1 November; occasional stragglers remain to 1 December.

Nesting Season Distribution: Common to locally abundant breeding species in all regions. Breeding Bird Survey data (Table 7) demonstrate a marked increase in relative abundance westward through the Valley. Average numbers recorded per route range from $<1$ in Douglas County (Minong BBS) and 32.2 in Polk County (Loraine BBS) to 133.7 in St. Croix County (Hudson BBS). This trend in breeding population distribution is the reverse of the eastern meadowlark.

Winter: Meadowlarks are fairly regular during winter months in the Western Upland. Many of these records are probably referable to western meadowlark; however, plumages are similar to the eastern meadowlark, which confounds identification.

Habitat: Highest density breeding populations occur in retired croplands and Managed Grasslands where characteristic vegetation includes timothy, brome grass, quack grass, and intermediate wheat grass. Nesting western meadowlarks also use heavily grazed pastures, Hayland, remnant prairie associated with oak savannah, and Old Field Communities. In the Central Plain and Northern Highland, nesting pairs occasionally occupy drier portions of Northern Sedge Meadow. 


\section{Yellow-headed Blackbird (Xanthocephalus xanthocephalus)}

Status: Regular migrant and nesting species.

Migration: Fairly common (locally common) migrant in the Western Upland, uncommon and local in the Central Plain, and rare in the Northern Highland. Spring migrants arrive in the Western Upland about 15 April, reaching the Northern Highland by 1 May. Peak spring abundance occurs 1-15 May and nonbreeding birds depart by 20 May. Fall migration begins with dispersal from breeding marshes and the formation of loose flocks in late July. Peak fall abundance occurs 15 August to 1 September and departure by 30 September (latest-9 October 1966, Washington County).

Nesting Season Distribution: Common to locally abundant breeding bird in central St. Croix, Washington, and southern Polk counties. I conducted a census of breeding yellow-headed blackbirds in 1975 and found over 1,000 pairs in central St. Croix County; a 1977 census yielded fewer than 500 pairs. The difference was attributed to persistent drought conditions. Documented breeding records exist for St. Croix, Washington, Polk, and Burnett counties. Breeding Bird Survey data (Table 7) suggest that the largest breeding populations occur in the Western Upland. An isolated breeding population exists at Crex Meadows Wildlife Area, Burnett County. Ellarson (1950) reported two additional colonies in Burnett County in 1948 and 1949 which were still occupied in 1977. Green and Janssen (1975) stated that this species is absent from "much of Pine County."

Habitat: Characteristic nesting species of deep semipermanently and permanently flooded wetlands. Predominant vegetation associated with yellowheaded blackbird nesting habitat includes cattail, river bulrush, hardstem bulrush, and phragmites.

\section{Red-winged Blackbird (Agelaius phoeniceus)}

Status: Regular migrant, nesting species, and winter resident.

Migration: Abundant migrant throughout the Valley. Spring migrants arrive in late February in the Western Upland, reaching the Northern Highland by 15 March. Peak spring migration occurs 15 March to 10 April. Fall migration begins in mid-July with dispersal from nesting areas and the formation of loose flocks. Numbers gradually build through August reaching peak abundance 10-25 September. During this period, roost flocks ranging from 25,000 to 50,000 individuals can be observed. Most fall migrants have departed by 1 November; however, stragglers remain into early December.

Nesting Season Distribution: Abundant nesting species in the Western Upland and Central Plain, common in the Northern Highland. Breeding Bird Survey data (Table 7) suggest that a very large breeding population exists in the open agricultural areas of the Western Upland and Central Plain. This breeding population diminishes in abundance in the more forested Northern Highland. 
Winter: Regular winter resident in the Western Upland, casual elsewhere. Wintering red-winged blackbirds are usually associated with Lowland Deciduous Forest, Shrub Carr, Alder Thicket, natural basin wetlands, farm. steads, and feedlots.

Habitat: Red-winged blackbirds use a variety of wetland and upland sites for nesting. Wetlands include sedge meadows, seasonally, semipermanently, and permanently flooded wetlands dominated by cattail, river bulrush, hardstem bulrush, softstem bulrush, and phragmites. Alder Thicket, Shrub Carr, northern Forest Bordered Wetlands, and Black Spruce-Tamarack Bogs are also important. Upland nesting sites include agricultural fields, Old Field Community, Hayland, Managed Grasslands, and to a lesser extent Northern Hardwood Forest, Southern Deciduous Forest, and Lowland Deciduous Forest. This species is among the most widespread and adaptable breeding birds in the Valley.

\section{Orchard Oriole (Icterus spurius)}

Status: Casual migrant and nesting species.

Migration: Rare migrant in Pierce, St. Croix, and Washington counties; accidental elsewhere. Migrants arrive 15-20 May, remaining in this region until mid-August. There are two spring records for Polk County: 20 May 1949 and 20 May 1976.

Nesting Season Distribution: Several nesting season records exist in the Western Upland; however, only one confirmed nesting record exists. A nest with eggs was found in Washington County on 15 July 1953 (Herz 1954). S. Sprunt found a singing male near Gordon, Douglas County, on 6 July 1956 (Lound and Lound 1956b). Recently, nesting season adults have been regularly observed along the lower Willow River in St. Croix County. Although nest records have not been obtained here, strong evidence of nesting exists.

Habitat: Breeding season orchard orioles are typically associated with open areas in mature Lowland Deciduous Forest.

\section{Northern Oriole (Icterus galbula)}

Status: Regular migrant and nesting species.

Migration: Common migrant throughout the Valley, locally abundant adjacent to the St. Croix River in St. Croix, Pierce, and Washington counties. Spring migrants arrive in the Western Upland 1-5 May and peak populations occur 15-20 May. Spring migrants arrive in the Northern Highland by 10 May (earliest-26 April 1957, Burnett County; Lound and Lound $1957 \mathrm{c}$ ), reaching peak populations 20-25 May. Fall migration begins in late July. Peak movement in the Northern Highland occurs 5-20 August and departure is by 10 September. Peak fall migration in the Western Upland occurs 15-30 August and departure is by 15 September (latest-1 December 1971, Washington County).

Nesting Season Distribution: Common nesting species in the Western 
Upland and Central Plain, uncommon and local in the Northern Highland. Breeding Bird Survey data (Table 7) suggest that the region of greatest abundance is the Central Plain. Unfortunately, the Hudson BBS route does not traverse large expanses of northern oriole habitat as this species is a common breeding bird in that area. A recent increase in breeding populations is suggested by Jackson's (1943) statement that this species was "nowhere common in the region except at St. Croix Falls," (Polk County). Goddard (1972) reported a density of 20.7 pairs per 40 ha in the Kinnickinnic River Valley, Pierce County.

Habitat: The northern oriole is primarily a species of mature deciduous forest. Also fairly common in ornamental plantings in residential areas. The largest breeding populations occur in mature Northern Hardwood Forest and Lowland Deciduous Forest.

\section{Rusty Blackbird (Euphagus carolinus)}

Status: Regular migrant and occasional early winter resident.

Migration: Common spring and abundant fall migrant throughout the Valley. Spring migrants arrive in the Western Upland about 10 March and reach the Northern Highland by 25 March. Peak spring populations occur 1-20 April and departure is by 5 May. Fall migrants arrive about 15 September, reaching peak populations 10-25 October. Most have departed from the Northern Highland by 10 November and elsewhere by 1 December.

Winter: Early winter records of this species consist primarily of small flocks associated with lowland forest habitats. Christmas Bird Count data suggest that early winter occurrences are restricted largely to areas adjacent to the lower St. Croix River. However, one record of an individual on the Solon Springs CBC was probably of a late migrant. During January and February, single birds will occasionally frequent feeding stations, including one at a Polk County feeder through 17 February 1959 (Winkler 1959).

Habitat: The rusty blackbird is primarily a species of wetland habitats. Fall concentrations of these birds are typically observed in large Alder Thickets, Shrub Carr, or northern bog habitats. Edges of prairie wetlands are also heavily used, primarily in the Western Upland.

\section{Brewer's Blackbird (Euphagus cyanocephalus)}

Status: Regular migrant and nesting species.

Migration: Fairly common spring and uncommon fall migrant throughout the Valley. Spring migrants arrive in the Western Upland 10-15 March, reaching the Northern Highland by 1 April. Peak migration occurs 10-30 April and departure from nonbreeding areas by 10 May. Fall migrants arrive in the Western Upland 10-15 August. Peak fall populations occur 25 August to 15 September and departure is by 10 October.

Nesting Season Distribution: Fairly common to locally uncommon nesting species in the Central Plain and Northern Highland. Roberts (1932) de- 
scribed the eastward extension of this species' breeding range from the Red River Valley to east-central Minnesota in the early 1900's. Additional evidence of recent expansion into this region is provided by Jackson (1943) who failed to record this bird in northwestern Wisconsin in 1919.

Winter: Several CBC records of Brewer's blackbird exist for the Suburban St. Paul count. These records include: 4 on 29 December 1962, 4 on 26 December 1964, and 11 on 30 December 1972.

Habitat: Brewer's blackbirds primarily use fencerows, railroad rights-ofway and Old Field habitats. Occasional breeding pairs are encountered in Northern Sedge Meadow, open bog habitats, and in highway rights-of-way.

\section{Common Grackle (Quiscalus quiscula)}

Status: Regular migrant, nesting species, and winter resident.

Migration: Abundant migrant in the Western Upland and Central Plain, fairly common (locally common) in the Northern Highland. Spring migrants arrive in the Western Upland 20-25 February, reaching the Northern Highland by 30 March. Peak populations occur 20 March to 15 April. Fall migration begins in mid-July with dispersal from breeding areas. Large mixed flocks of common grackles and red-winged blackbirds form in early August, supplemented with Brewer's blackbirds in late August and rusty blackbirds in late September. Peak fall populations occur 10 September to 10 October. Departure from the Northern Highland occurs by 15 October and most birds have departed from the Western Upland by 5 November but stragglers remain to 30 November.

Nesting Season Distribution: Common to locally abundant nesting species in the Western Upland and Central Plain, uncommon to locally common in the Northern Highland. This is one of the most rapidly increasing nesting species in the Valley. Breeding Bird Survey data (Table 7) show a gradual decrease in relative abundance northward from the heavily farmed regions of the Western Upland. In 1919, Jackson (1943) reported that common grackles were "never particularly plentiful, except when they gathered in flocks." The current abundance of this species and the expansion of its breeding range has been fairly recent and may be associated with an expanding human population or changes in agricultural practices.

Winter: Common grackles occasionally overwinter each year in the Western Upland. Individual birds elsewhere may be wintering or late migrants.

Habitat: Common grackles are fairly opportunistic in their selection of nesting habitats and have been recorded in nearly every habitat type. Highest breeding densities are usually associated with Pine Plantations, deciduous woodlots, or ornamental conifer plantings. The increased planting of coniferous trees has enhanced common grackle nesting populations and may be a factor in their expanding and increasing populations.

\section{Brown-headed Cowbird (Molothrus ater)}

Status: Regular migrant and nesting species, casual early winter resident. 
Migration: Abundant spring and uncommon fall migrant throughout the Valley. Spring migrants arrive in the Western Upland 15-20 March and reach the Northern Highland by 10 April. Peak spring populations occur 10-25 April. Fall migration begins with flock formation in late June. A gradual movement away from breeding areas occurs throughout the fall; consequently, no peak population dates can be given. Most migrants have departed by 15 September and stragglers remain through October.

Nesting Season Distribution: Common to locally abundant nesting species throughout the Valley. Breeding Bird Survey data (Table 7) show a large and well-distributed breeding population. Goddard (1972) reported a density of 24.2 pairs per 40 ha in the Kinnickinnic River Valley, Pierce County.

Winter: Several early winter records exist from CBC's in Washington, St. Croix, and Douglas counties. These records include: 1 January 1970 (St. Croix); 1 January 1975, and 3 January 1976 (Washington); and 18 December 1974 (Douglas).

Habitat: Brown-headed cowbirds use virtually all habitats in this region. Largest breeding populations occur in woodland edge situations.

\section{FAMILY THRAUPIDAE: Tanagers}

\section{Scarlet Tanager (Piranga olivacea)}

Status: Regular migrant and nesting species.

Migration: Fairly common migrant throughout the Valley. Spring migrants arrive in the Western Upland 1-5 May, reaching the Northern Highland 5-10 May. Peak spring migration through the Valley occurs 10-25 May. Fall migration begins in mid-August. Peak fall migration occurs 25 August to 15 September and departure by 1 October.

Nesting Season Distribution: Fairly common nesting species throughout the Valley. This species is more widespread and probably occurs in greater densities in the Central Plain and Northern Highland. Bernard (1967) considered the scarlet tanager a common summer resident in Douglas County. Jackson (1943) reported this species as common at St. Croix Falls, Polk County, and mentions the observation of mated pairs at that location. Goddard (1972) reported a density of 4.5 pairs per 40 ha in the Kinnickinnic River Valley, Pierce County.

Habitat: Characteristic nesting species of deciduous forest communities. Habitat use by nesting scarlet tanagers varies with geomorphic province. In the Western Upland, this species is most abundant in mature Lowland Deciduous Forest and Southern Deciduous Forest. In the Central Plain and Northern Highland, scarlet tanagers are most abundant in mature Northern Hardwood Forest and in early successional stage aspen forest. Breeding pairs in Jack Pine Barren habitat are normally found in the "scrub" oak savannahs interspersed with jack pine. 


\section{Summer Tanager (Piranga rubra)}

Status: Casual, two records.

Records: One male was observed in Polk County on 18 May 1956 (Lound and Lound 1956a). Another male was observed at Grantsburg, Burnett County, on 29 September 1967 (Caldwell 1968).

FAMILY FRINGILLIDAE: Grosbeaks, Finches, Sparrows, and Buntings

\section{Cardinal (Cardinalis cardinalis)}

Status: Regular permanent resident.

Distribution: Fairly common (locally common) resident of the Western Upland. Uncommon to rare in the Central Plain, and rare and local in the Northern Highland. Movement of the cardinal into this region has been very recent. In 1919 Jackson (1943) failed to report this bird in northwestern Wis. consin. Young et al. (1941) reported that the first records for Burnett and Pierce counties were in 1920. Roberts (1932) reported several mid-1920 records for the Washington County region. By the 1960's Bernard (1967) considered this bird a rare visitor in Douglas County and mentioned records from Solon Springs. M. Link (personal communication) reported that cardinals were regular at Pine City, Pine County, in 1974.

Breeding season records of the cardinal provide excellent documentation of their decreasing population, which is moving northward through the Valley. Breeding Bird Survey data (Table 8) suggest an abrupt decrease in breeding density from a mean of 1.5 per route in the Western Upland to $<0.1$ per route in the Northern Highland. Goddard (1972) found the mean density of breeding cardinals in the Kinnickinnic River Valley was 16 pairs per 40 ha.

Winter: Common winter resident in the Western Upland. As shown for the breeding season, the abundance of this bird decreases rapidly as it moves northward. On five CBC's in the Valley, the mean number of cardinals recorded per party hour ranged from 3.1 on the Afton $\mathrm{CBC}$ to 0 at Solon Springs (Table 4).

Habitat: Primarily a species of deciduous forest edge during the breeding season. Use of Lowland Deciduous Forest and Southern Deciduous Forest is usually restricted to openings and brushy edges. Highway rights-of-way and windbreaks planted around farmsteads are important, as are shrubbery and ornamental plantings in residential areas.

\section{Rose-breasted Grosbeak (Pheucticus ludovicianus)}

Status: Regular migrant and nesting species.

Migration: Common migrant throughout the Valley. Spring migrants arrive 1-5 May (earliest-30 April 1978, St. Croix County), reaching peak abundance 10-20 May. Fall migration begins in the Northern Highland 
15-25 August. Peak fall migration through the Valley occurs 5-20 September. Departure from the Northern Highland occurs 20-25 September and elsewhere by 5 October (latest-26 October 1965, Washington County).

Nesting Season Distribution: Fairly common (locally common) nesting species in the Western Upland. Population densities apparently increase northward through the Valley. Goddard (1972) reported a density of 31.2 pairs per 40 ha along the Kinnickinnic River Valley in Pierce County; the rose-breasted grosbeak was the fifth most abundant breeding bird in that valley. Breeding Bird Survey data (Table 8 ) suggest that rose-breasted grosbeaks occur in greatest abundance in the Northern Highland.

Habitat: The rose-breasted grosbeak is a characteristic breeding species of mature deciduous forest and forest edge. In the Western Upland, this grosbeak uses Southern Deciduous Forest dominated by mixed stands of white, red, black, and bur oaks. Also important is mature Lowland Deciduous Forest characterized by cottonwood, green ash, and American elm along the major river systems. In the Central Plain and Northern Highland, primary use is made of mature Northern Hardwood Forest dominated by sugar maple, basswood, trembling aspen, and white birch. Residential Habitats, primarily ornamental shade trees, are also used for nesting.

Table 8. Mean number of grosbeaks, finches, towhees, and sparrows recorded on western Wisconsin Breeding Bird Survey transects, 1966-78.

\begin{tabular}{|c|c|c|c|c|c|}
\hline \multirow[b]{2}{*}{ Species } & \multirow{2}{*}{$\begin{array}{l}\text { Western } \\
\text { Upland } \\
\text { Hudson }\end{array}$} & \multicolumn{2}{|c|}{ Central Plain } & \multicolumn{2}{|c|}{ Northern Highland } \\
\hline & & Dresser & Loraine & Union & Minong \\
\hline Cardinal & 1.5 & 0.6 & 0.0 & $<0.1$ & $<0.1$ \\
\hline Rose-breasted grosbeak & 6.0 & 32.2 & 18.1 & 15.0 & 19.6 \\
\hline Indigo bunting & 7.4 & 8.7 & 23.3 & 18.5 & 18.6 \\
\hline Dickcissel & 12.1 & 6.4 & 5.4 & 0.0 & 0.0 \\
\hline American goldfinch & 4.7 & 9.1 & 20.6 & 6.0 & 5.9 \\
\hline Purple finch & 0.0 & 0.0 & 0.0 & 1.0 & 3.3 \\
\hline Pine siskin & 0.0 & 0.0 & $<0.1$ & $<0.1$ & 0.2 \\
\hline Rufous-sided towhee & 0.2 & 0.2 & 0.6 & 21.7 & 15.8 \\
\hline Savannah sparrow & 17.3 & 14.1 & 26.3 & 0.0 & 0.3 \\
\hline Grasshopper sparrow & 9.6 & 5.7 & 6.7 & 0.7 & 0.0 \\
\hline Henslow's sparrow & 1.2 & 1.1 & 0.5 & 0.0 & 0.0 \\
\hline Vesper sparrow & 18.9 & 15.3 & 13.7 & 6.5 & 8.6 \\
\hline Dark-eyed junco & 0.0 & 0.0 & 0.0 & 0.0 & 0.6 \\
\hline Chipping sparrow & 1.6 & 6.3 & 10.9 & 21.2 & 24.2 \\
\hline Clay-colored sparrow & 4.4 & 3.0 & 2.7 & 7.2 & 14.9 \\
\hline Field sparrow & 7.0 & 3.2 & 2.2 & 10.2 & 1.9 \\
\hline White-throated sparrow & 0.0 & 0.0 & $<0.1$ & 0.0 & 3.5 \\
\hline Lincoln's sparrow & 0.0 & 0.0 & 0.0 & 0.0 & $<0.1$ \\
\hline Swamp sparrow & 0.0 & 0.2 & 0.9 & 0.2 & 1.1 \\
\hline Song sparrow & 12.9 & 24.4 & 32.6 & 3.5 & 24.0 \\
\hline
\end{tabular}




\section{Black-headed Grosbeak (Pheucticus melanocephalus)}

Status: Casual spring migrant.

Records: This western grosbeak has been recorded in the Valley on four occasions. The first record was a male on 27 May 1970 in Washington County (Huber 1974a). A female was observed in Washington County 11 May to 1 June 1974, and a male was noted in the same location on 13 May 1974 (Savaloja 1974). I observed a singing male in Glen Park at River Falls, Pierce County, on 25 May 1979 (Eckert 1979).

\section{Indigo Bunting (Passerina cyanea)}

Status: Regular migrant and nesting species.

Migration: Common migrant in the Western Upland and Central Plain, uncommon (locally common) in the Northern Highland. Spring migrants arrive in the Western Upland 1-5 May (earliest-26 April 1976. Pierce County) and reach the Northern Highland 5-10 May. Peak spring migration through the Valley occurs 15-30 May. Fall migration begins about 10-15 August. Peak fall migration occurs 1-15 September and departure 20 September to 5 October.

Nesting Season Distribution: Common and well-distributed nesting species in the Western Upland and Central Plain. Fairly common in the Northern Highland, except in regions of extensive coniferous forest. Jackson (1943) considered the indigo bunting an uncommon nesting bird in the Northern Highland in 1919. In the Western Upland, Goddard (1972) found the indigo bunting was the 12 th most numerous breeding bird $(\overline{\mathrm{X}}=21.8$ pairs per 40 ha) along the Kinnickinnic River Valley, Pierce County. Breeding Bird Survey data (Table 8) suggest that lowest populations occur in the heavily farmed regions of the Central Plain but increase northward into the Northern Highland.

Habitat: The indigo bunting is a characteristic breeding bird of shrubby "edge" habitat types. In the Central Plain and Northern Highland, Deciduous Clear Cuts under 10 years old receive heavy use by nesting indigo buntings. Important vegetation associated with their breeding habitat includes trembling aspen, box elder, basswood, choke cherry, hazelnut, and prickly ash.

\section{Dickcissel (Spiza americana)}

Status: Regular migrant and nesting species.

Migration: Common migrant in the Western Upland and Central Plain, rare and local in the Northern Highland. Populations of this bird experience tremendous variations between years and they appear to be cyclic. In adjacent years, dickcissels can vary from among the most numerous migrants in grassland habitats to virtually absent. Spring migrants arrive in the Western Upland and Central Plain 20-30 May and are widespread 
1-10 June. During most years, this bird is most numerous during the first 10 days of June. Singing ceases about 1 August and birds become difficult to find after that date. There is no discernible peak in fall migration, and most have departed by 25 August (latest-16 September 1974, Polk County).

Nesting Season Distribution: Fairly common although highly irregular nesting species in the Western Upland and Central Plain. There are no known nest records for Douglas or Pine counties, although Green and Janssen (1975) stated that the breeding range in Minnesota "usually extended only to southern Pine County." Jackson (1943) did not record this species in northwestern Wisconsin during 1919.

During 1975, the dickcissel was virtually absent from St. Croix and Washington counties during the nesting season. In 1976, I recorded a density of 20.4 pairs per 40 ha on Managed Grassland tracts in St. Croix and Polk counties. Breeding Bird Survey data (Table 8 ) provide another indication of the rapid decrease in abundance moving northward from the Western Upland to Northern Highland.

Habitat: Characteristic breeding bird of retired agricultural fields that have become overgrown with a rank growth of vegetation. Also an important breeding bird of alfalfa fields and of Managed Grasslands that are maintained by various State and Federal wildlife agencies for duck nesting cover.

\section{Evening Grosbeak (Hesperiphona vespertina)}

Status: Regular migrant and winter resident, casual summer visitor, and possible nesting species.

Migration: Common yet erratic fall and spring migrant in the Western Upland and Central Plain. Usually a common to abundant migrant in the Northern Highland. Migration periods appear to depend upon the abundance of a food source in the northern breeding areas. The first fall migrants usually arrive in the Northern Highland 1-15 October and reach the Western Upland about 15 November, except during invasion years, when they have been recorded in mid-October (15 October 1959, Polk County). Peak fall migration varies with the year, however, usually occurring 15 November to 15 December. Peak spring migration usually occurs during March. During non-invasion years, peak spring migration occurs 25 March to 5 May. The largest late flock on record (600) was observed at Webster (Burnett County) on 25 April 1950. Departure also apparently varies with the year. There are several Polk County departure records that range from 4 May (1954) to 17 May (1952). Latest dates from nonsummering areas include 28 May 1962, Polk County and 30 May 1972, Burnett County.

Nesting Season Distribution: Casual summer resident in the Northern Highland. There are no confirmed nest records for the Valley, although a few pairs may remain to nest after invasion years. Evening grosbeaks were recorded during the 1972 summer in Pine County (Green and Baumhoffer 1972). S. D. Robbins recorded evening grosbeaks along the route of the Minong BBS during mid-June from 1965 to 1977 . During June $1974 \mathrm{I}$ ob- 
served three male evening grosbeaks in Sec. 14, T. 43 N., R. 15 W., Douglas County, but no evidence of nesting.

Winter: Usually a common to locally abundant winter resident in the Northern Highland. Uncommon to rare (except during invasion years) winter resident in the Central Plain and Western Upland. The highest mean numbers of evening grosbeaks per party hour on CBC are 8.3 at Grantsburg and 3.3 at Solon Springs (Table 4), both in the Northern Highland. The highest count of individuals on CBC's was 739 recorded on the 1974 Grantsburg Count. Considerable variation also exists in yearly totals, which is indicative of the cyclic influxes of this species.

Habitat: Migrant evening grosbeaks use both deciduous and coniferous habitats. Box elder and maple trees that retain their fruits are preferred during migration. Most winter records are obtained from the vicinity of feeding stations, both in rural and urban areas. My records of this bird during the breeding season were obtained from an extensive stand of black spruce adjacent to a stream. This vegetation type appears to be preferred in the northern breeding areas.

\section{Purple Finch (Carpodacus purpureus)}

Status: Regular migrant, nesting species, and winter resident.

Migration: Common migrant in the Western Upland and Central Plain, occasionally abundant in the Northern Highland. Fall migration begins in the Northern Highland about 25 August and the first birds arrive in the Western Upland 15-25 September. Peak fall migration occurs 1 October to 15 November and departure from nonwintering areas by 1 December (latest-18 December 1979, Douglas County). Spring migrants arrive in the Northern Highland about 15 March. Peak spring migration occurs 25 March to 15 April and departure by 1 May (latest-10 May 1970 and 17 May 1966. Washington County).

Nesting Season Distribution: Fairly common nesting species in the Northern Highland. Confirmed nest records exist for Burnett, Polk, and Douglas counties. Green and Janssen (1975) cited an inferred breeding record for Pine County. Breeding Bird Survey data (Table 8 ) suggest that nesting is restricted to the Northern Highland. The most southerly nest record that I have obtained was a female incubating four eggs on 26 May 1974 near Clam Falls, Polk County (Sec. 11, T. 35 N., R. 15 W.). Jackson (1943) observed a mated pair at St. Croix Falls, Polk County, on 25 May 1919.

Winter: Common (locally abundant) winter resident in the Western Upland. Becomes progressively more scarce in the Central Plain and is virtually absent from the Northern Highland. Christmas Bird Count data (Table 4) demonstrate sharp declines in winter abundance moving northward from the lower St. Croix River. On 1 January 1978, 294 were recorded on the Afton CBC. On 16 February 1979, I banded 105 at a feeding station in Hudson, St. Croix County.

Habitat: During the nesting season, the purple finch is a characteristic 
species of cool, moist, Lowland Coniferous Forest. Principal vegetation associated with breeding habitat includes black spruce, tamarack, yellow birch, and black ash. All purple finch nests that I have observed were associated with this vegetation type. During migration, purple finches were also found in deciduous habitats, primarily those having heavily seeded box elder. Wintering birds are usually found in black spruce habitat or near feeding stations in residential areas.

\section{Pine Grosbeak (Pinicola enucleator)}

Status: Regular migrant and winter resident.

Migration: Uncommon fall migrant (occasionally common) in the Northern Highland, rare and irregular fall migrant (occasionally fairly common) in the Central Plain and Western Upland. Less common in all regions during spring migration, except after invasions. On 23 November 1946 pine grosbeaks were already considered "numerous" at Grantsburg, Burnett County. Fall migrants arrive in the Northern Highland 25 October to 15 November. Peak fall migration occurs 15 November to 15 December. Spring migration begins with a gradual northward exodus in late February. Peak spring migration occurs 1-15 March and departure by 1 April (latest-8 May 1974. Polk County).

Winter: Irregular winter resident except for the Northern Highland where wintering pine grosbeaks are observed each year. Winter populations of this bird are considered cyclic. The largest number recorded in the Valley was 436 on the Solon Springs CBC 17 December 1970. Christmas Bird Count data (Table 4) provide supportive evidence of their relative abundance in the various regions of the Valley.

Habitat: Generally restricted to extensive stands of Lowland Coniferous Forest and Jack Pine Barrens. During invasion years, pine grosbeaks use Upland Deciduous Forest, especially if box elder and maple or sumac trees are heavily laden with seeds.

\section{Gray-crowned Rosy Finch (Leucosticte tephrocotis)}

Status: Accidental, one record.

Record: Ludwig (1974) described the observation of a single gray-crowned rosy finch in Pine County 27 March to 6 April 1974. This was the third record of that species in Minnesota.

\section{Hoary Redpoll (Carduelis hornemanni)}

Status: Irregular migrant and winter resident.

Migration: During invasion years, a rare migrant in the Northern Highland and Central Plain, casual in the Western Upland. There are too few spring records to establish patterns. Fall migrants usually arrive with the first large flocks of common redpolls in late November (earliest-3 November 
1968, Burnett County; 21 November 1950, Polk County). During spring migration, hoary redpolls are observed with common redpoll flocks. Most observations occur in February. Late dates include 4 April 1966, St. Croix County; 6 April 1969, Chisago County; and 12 April 1974, Washington County.

Winter: Rare and irregular winter resident throughout the Valley. Most winter records consist of observations during the $\mathrm{CBC}$ periods, usually 15 December to 2 January. The largest number observed (six) was recorded on the Suburban St. Paul CBC 29 December 1973. Considerable debate has been generated concerning the taxonomic status of this bird and the ability of observers to make accurate identification. The most reliable and undoubtedly correct observations are of banded birds. One individual was banded in Chisago County on 1 March 1970. During the winter finch invasion of 1977-78, I banded two hoary redpolls at a feeding station in Hudson, St. Croix County, on 15 February 1978 and 8 March 1978. The latter bird was photographed extensively and copies were deposited with the Wisconsin Society for Ornithology.

Habitat: Regularly observed with flocks of common redpoll in weedy fields and highway rights-of-way.

\section{Common Redpoll (Carduelis flammea)}

Status: Regular migrant and winter resident.

Migration: Abundant migrant throughout the Valley during periodic invasion years, uncommon to rare migrant during other years. Fall migrants arrive 25 October to 10 November (earliest-12 October 1974, Burnett County). Peak fall migration occurs 15 November to 15 December. Peak spring migration occurs 1-25 March; birds depart from the Central Plain 1-10 April and the Northern Highland by 30 April (latest-30 May 1972, Burnett County).

Winter: Usually an uncommon winter resident except during invasion years when this species becomes one of the most abundant wintering birds. Christmas Bird Count data (Table 4) suggest that the wintering population is fairly well distributed throughout the Valley. The extremely high mean number of common redpolls per party hour on the Solon Springs CBC is skewed upward by a large count during 1977.

The normal 2-year invasion cycle of this bird is shown by comparing the mean number of redpolls per party hour on CBC's throughout the Valley (Fig. 6). Beginning with the 1970 count year, the winter common redpoll population fits a perfect alternate year invasion schedule. Results from the 1977-78 CBC season are considerably higher than other years because the movement of birds that year was one of the largest recorded. The two largest counts on record in the Valley are from the Solon Springs CBC $(2,222)$ and Suburban St. Paul CBC $(4,615)$. The 4,615 is the largest number ever recorded in North America (Monroe 1978).

Habitat: Agricultural fields, retired cropland that has become heavily over- 


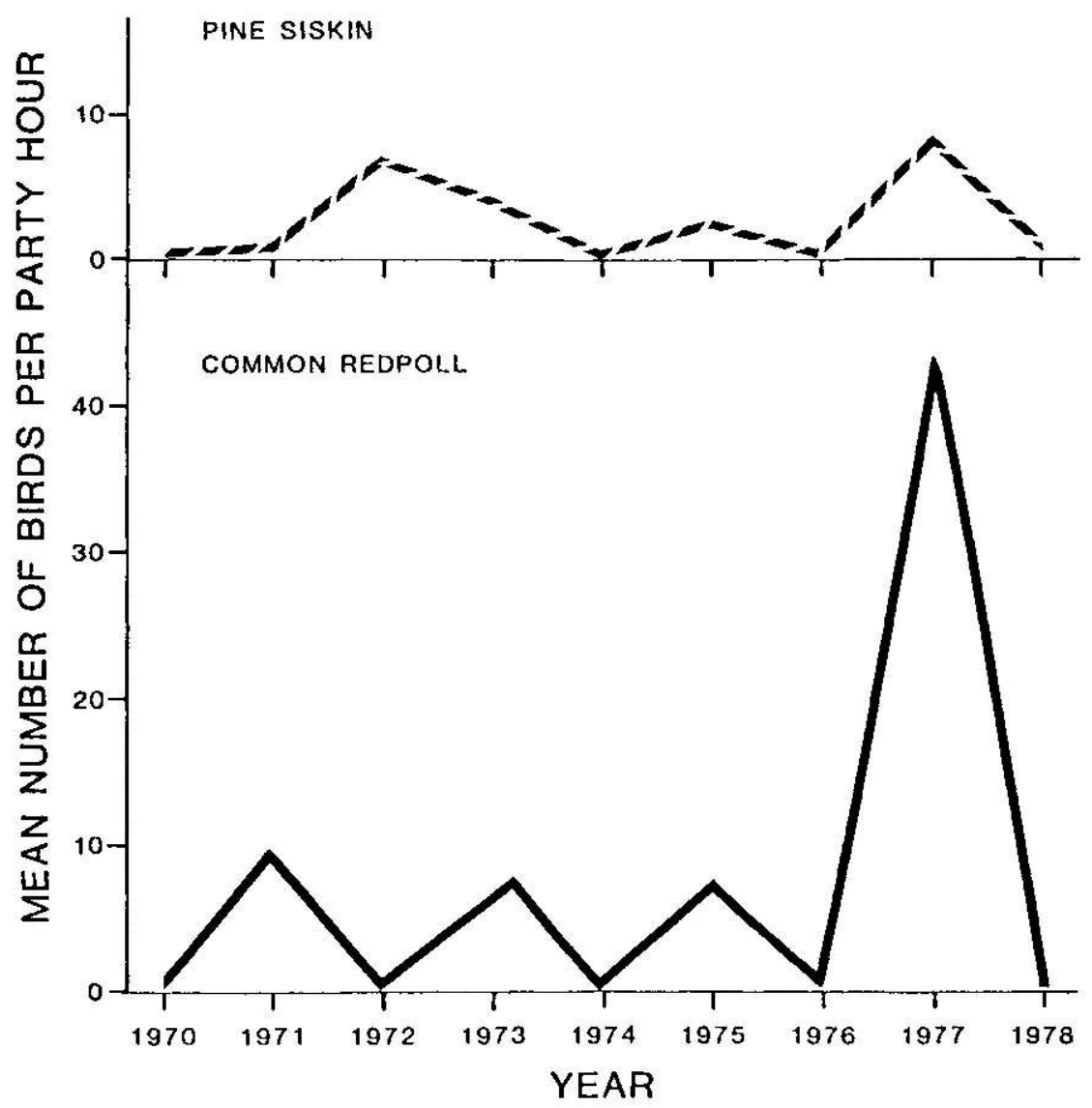

Fig. 6. Patterns of winter abundance of common redpolls and pine siskins in the St. Croix River Valley (data from Christmas Bird Counts).

grown with various weeds, highway rights-of-way, and mixed deciduous-coniferous forest in northern regions.

\section{Pine Siskin (Carduelis pinus)}

Status: Regular migrant, nesting species, and winter resident.

Migration: Fairly common (occasionally abundant) migrant throughout the Valley. Fall migrants arrive in the Central Plain and Western Upland 15- 25 September. Peak fall migration occurs 10-30 October and departure by 15 November. The number of fall migrants is highly dependent on the intensity of the migration during a given year. Typical of other winter finches, peak movements usually occur during invasion years. Migrants have usually departed the Northern Highland by 1 January, except during years of very high populations when large numbers winter throughout the Valley. 
Spring migration begins in late March with a gradual exodus from the southern wintering areas. Spring migration is usually more diffuse than fall and the period of peak movement occurs 10 April to 15 May. Departure from the southern areas occurs 20-30 May.

Nesting Season Distribution: Uncommon nesting species in the Northern Highland. Jackson (1943) reported that pine siskins were "not uncommon" at Solon Springs (Douglas County) from 26 July to 6 August 1919 . He does not provide any evidence of nests or young. Larson (1970) reported pine siskins at Taylor's Falls, Chisago County, through the summer of 1969 and until 10 August 1970. No nests or young were reported. On 11 May 1978, I banded a female pine siskin at Hudson. St. Croix County, that possessed a well-defined brood patch. Although no nests or young were observed, pine siskins remained in the area throughout the summer of 1978 and probably nested.

Winter: Fairly common resident in the Western Upland and Central Plain. Uncommon to rare during midwinter in the Northern Highland except during invasion years. Christmas Bird Count data (Table 4) suggest a rapid decline in relative abundance of this species moving northward from the lower St. Croix River Valley. Although not as predictably cyclic as the common redpoll, the pine siskin follows a pattern of abundance 1 year, followed by low numbers for 2-3 years afterward (Fig. 6). Highest daily counts of individuals include 856 on 1 January 1974 (Afton CBC) and 793 on 2 Jan. uary 1978 (Suburban St. Paul CBC). On 10 February 1961 S. D. Robbins observed over 3,000 pine siskins at Clam Lake, Burnett County.

Habitat: Restricted primarily to coniferous forest during the nesting season. Wintering birds use a variety of coniferous and deciduous habitats. This species makes extensive use of feeding stations in residential areas.

\section{American Goldfinch (Carduelis tristis)}

Status: Regular migrant, nesting species, and winter resident.

Migration: Common migrant throughout the Valley. Spring migrants arrive in the Western Upland 15-30 March, reaching peak abundance 15-30 April. Migrants arrive in the Northern Highland 10-15 April, reaching peak num. bers about 1 May. Fall migration begins in mid-August and peak populations occur 15 September to 15 October. Departure from the northern areas occurs by 15 November.

Nesting Season Distribution: Fairly common and well-distributed nesting species throughout the Valley. Jackson (1943) considered the American goldfinch one of the most generally distributed nesting species in northwestern Wisconsin. Breeding Bird Survey data (Table 8) support Jackson's statement. This bird was the fourth most abundant breeding species 133.2 pairs per $40 \mathrm{ha}$ ) in the Kinnickinnic River Valley, Pierce County (Goddard 1972).

Winter: Fairly common to locally common winter resident in the Western Upland and Central Plain. Rare and irregular winter resident of the North- 
ern Highland, particularly after mid-January. Christmas Bird Count data (Table 4) suggest a gradual decrease in relative abundance progressing northward. Highest daily counts include 559 on 30 December 1978 (Suburban St. Paul CBC) and 545 on 1 January 1975 (Afton CBC).

Habitat: Typically a nesting species of edge situations including stream banks, brushy edges of woods, highway rights-of-way, and ornamental shrubbery in urban areas.

\section{Red Crossbill (Loxia curvirostra)}

Status: Regular migrant and winter resident, irregular summer resident, and nesting species.

Migration: Irregular migrant throughout the Valley. During periods of peak occurrence, red crossbills are uncommon except in the Northern Highland where they become locally common. Because of their erratic movements, it is difficult to determine their migration periods, particularly in the Northern Highland. The normal period of occurrence in the Western Upland and Central Plain is 1 October to 1 April; stragglers remain until mid-May.

Nesting Season Distribution: Rare and irregular during the nesting season, primarily in the Northern Highland. Jackson (1943) mentioned the observation of a "flock" at Solon Springs, Douglas County, on 8 August 1919. Jackson (1970) provided the only confirmed nesting record for the Valley when he observed several adults feeding young at Stillwater, Washington County, during May 1970. Larson (1970) found red crossbills near Taylor's Falls, Chisago County, until 5 June 1970 but no evidence of nesting.

Winter: Uncommon and irregular winter resident, usually observed in the Northern Highland. Although this species is dependent on the pinecone crop, population irruptions of red crossbill are not predictable.

Habitat: Breeding season records are typically associated with Lowland Coniferous Forest or Northern Hardwood Forest intermixed with coniferous trees.

\section{White-winged Crossbill (Loxia leucoptera)}

Status: Regular migrant and winter resident, erratic summer resident.

Migration: Uncommon to rare migrant; most observations are confined to the Northern Highland. Similar in distribution to the red crossbill in occurrence and distribution. During years of peak influxes, white-winged crossbills are locally common to abundant, primarily in the Northern Highland and Central Plain. The normal period of occurrence ranges from 15 October to 15 March.

Nesting Season Distribution: There are no confirmed nest records of this crossbill in the Valley. S. D. Robbins recorded single birds along the route of the Minong BBS, Douglas County, on 11 June 1969 and 21 June 1977. Robbins observed two white-winged crossbills along the route of the Union BBS, Burnett County, on 22 June 1977. 
Winter: Uncommon to locally common winter resident in the Northern Highland. Rare to uncommon winter resident elsewhere. During the winter of 1977-78, the movement of this bird into the Valley was among the largest on record. Exceptionally large flocks (200 individuals) were noted, primarily north of St. Croix Falls. These large numbers remained through mid-December. After that time, the number of individuals decreased considerably.

Habitat: This species primarily uses extensive stands of Lowland Coniferous Forest where white spruce is the predominant tree species. Also occasionally observed in mixed coniferous-deciduous forest and Jack Pine Barren.

\section{Green-tailed Towhee (Pipilo chlorura)}

Status: Accidental, one record.

Record: Garber (1965) reported the observation of one bird at Prescott, Pierce County, on 10 May 1964.

\section{Rufous-sided Towhee (Pipilo erythrophthalmus)}

Status: Regular migrant and nesting species.

Migration: Uncommon migrant throughout the Valley, common in the Northern Highland. Spring migrants arrive in the Western Upland 25-30 April and the Northern Highland 1-5 May. Peak migration occurs 5-15 May. Peak fall migration occurs 10-25 September and departure by 15 October (latest -8 December 1971, Washington County).

Nesting Season Distribution: Uncommon nesting species throughout the Valley. Jackson (1943) reported that rufous-sided towhees were common at Solon Springs, Douglas County, 28 July to 6 August 1919. Goddard (1972) reported a density of 19.3 pairs per 40 ha in the Kinnickinnic River Valley, Pierce County. Breeding Bird Survey data (Table 8 ) suggest that the rufoussided towhee occurs in relatively low numbers in the Western Upland and Central Plain and is common in the Northern Highland.

Habitat: Primarily a species of edge situations. Typical breeding habitat includes semi-open stands of Northern Hardwood Forest (Western Upland). Typical vegetation of these habitats includes second-growth bur oak, trembling aspen, sugar maple, green ash, and basswood. In the Northern Highland, this species becomes particularly numerous in mixed stands of jack pine and oak.

\section{Savannah Sparrow (Passerculus sandwichensis)}

Status: Regular migrant and nesting species.

Migration: Common spring and fall migrant throughout the Valley. Spring migrants arrive in the Western Upland 10-15 April and the Northern Highland about 20 April (earliest-30 March 1967, Burnett County). Peak spring migration through the Valley occurs 20 April to 10 May. Peak fall migration 
occurs 15-30 September and departure by 15 October (latest-25 October 1967, St. Croix County).

Nesting Season Distribution: Fairly common nesting species in the Western Upland and Central Plain, uncommon and more localized in the Northern Highland. Breeding Bird Survey data (Table 8 ) suggest that in the Western Upland and Central Plain the savannah sparrow is among the three most common nesting sparrows. However, this abundance decreases rapidly moving northward into the heavily forested Northern Highland.

Habitat: Characteristic breeding species of various grassland communities. Important among these are retired cropland, Old Field Community, highway rights-of-way, Managed Grasslands maintained for duck production, and lightly to moderately grazed tame pasture that is predominantly timothy or Kentucky bluegrass. Also important, although to a lesser degree, are alfalfa and oat fields. In Northern regions, savannah sparrows make extensive use of wet meadow habitats, primarily Northern Sedge Meadow.

\section{Grasshopper Sparrow (Ammodramus savannarum)}

Status: Regular migrant and nesting species.

Migration: Fairly common migrant throughout the Western Upland and Central Plain, uncommon to rare and localized in the Northern Highland. Spring migrants arrive in the Western Upland 25 April to 1 May and the Northern Highland about 5 May. Peak spring migration is difficult to determine, although it is widely distributed 5-15 May. During the fall, grasshopper sparrows are rarely encountered after the song period ceases about 1 August, but they are probably present until mid-September.

Nesting Season Distribution: Fairly common nesting species in the Western Upland and Central Plain, rare and local in the Northern Highland. Jackson (1943) did not record this sparrow during the 1919 nesting season in northwestern Wisconsin. Breeding Bird Survey data (Table 8 ) suggest that the breeding populations in the Western Upland and Central Plain occur in nearly equal abundance, becoming much smaller in the Northern Highland.

Habitat: Primarily a nesting species of various grassland communities. Important among these are retired croplands, unmowed highway rights-ofway, Managed Grasslands maintained for duck production, and lightly grazed tame pasture that is predominantly Kentucky bluegrass or timothy. Also important, although to lesser degrees, are alfalfa and oat fields. Occasional use is made of the drier portions of Shrub Carr wetlands and Northern Sedge Meadow.

\section{Baird's Sparrow (Ammodramus bairdii)}

Status: Hypothetical, two records.

Records: One bird was observed at Crex Meadows, Burnett County, on 12 May 1957 (Stone 1957). Goddard (1976) reported a single bird, also at Crex Meadows, on 2 May 1975. 


\section{Le Conte's Sparrow (Ammospiza leconteii)}

Status: Regular migrant and summer resident.

Migration: Rare migrant throughout the Valley, fairly common at Crex Meadows, Burnett County. Migrants arrive in the Western Upland about 5 May (earliest-24 April 1976, St. Croix County). LeConte's sparrow is most regularly observed 10-25 May. Fall migration records range from 3 September to 4 October (latest-11 October 1963, Burnett County).

Nesting Season Distribution: Green and Janssen (1975) show the breeding range of LeConte's sparrow extending throughout the three Minnesota counties. Although summer records exist for Burnett, Polk, and St. Croix counties, young have been observed only at Crex Meadows. The most southerly breeding season records include single birds near New Richmond, St. Croix County, on 15 June to 2 July 1964, and 16 June 1966 (Robbins 1969b), and a singing male near Roberts, St. Croix County, on 27 June 1977 (Sec. 32, T. 30 N., R. 18 W.). Robbins (1969b) also recorded LeConte's sparrow in two Polk County locations (T. 35 N., R. 16 W.) on 15 June 1968. Two late May records from Pine County (23 May 1970 and 29 May 1971) were probably of birds on breeding territory.

The best known and probably most extensively explored summer area for LeConte's sparrow is the Crex Meadows Wildlife Area, Burnett County. Southern (1962) found several LeConte's sparrows in the marshes at Crex Meadows between 23 June and 2 July 1959. Subsequent to his original observations, other birders have investigated this area extensively and have found that this species occurs commonly in proper habitat. On 10 June 1977, I recorded 11 singing males in one marsh at Crex Meadows (Sec. 15, T. 39 N., R. 18 W.). Frequency of occurrence and observations of apparent territorial behavior indicate that LeConte's sparrow still nests at Crex Meadows, although no nests have been obesrved recently. Intensive investigation of similar areas in Pine and southern Douglas counties should reveal additional breeding areas.

Habitat: Typical breeding habitat at Crex Meadows includes extensive stands of Northern Sedge Meadow characterized by manna grass, water sedge, bluejoint grass, rattlesnake grass, and dark-green bulrush. Breeding season records of this sparrow away from Crex Meadows have consisted of birds in drier upland grasses, primarily timothy, bromegrass, and Kentucky bluegrass.

\section{Henslow's Sparrow (Ammodramus henslowii)}

Status: Regular migrant and nesting species.

Migration: Rare migrant in the Western Upland and Central Plain. Spring migrants arrive in the Western Upland 25 April to 1 May. There is very little movement that could be considered peak spring migration. Most of the birds observed in the Valley appear to be on or near a nesting territory. A Henslow's sparrow was observed at Crex Meadows, Burnett County, on 15 May 1954. This is the only record for the Northern Highland. Fall migra- 
tion is similar to spring in that no well-defined movements have been observed. Most fall observations have been made during August (latest12 September 1977, St. Croix County).

Nesting Season Distribution: Rare and local nesting species, restricted primarily to the Western Upland and Central Plain (Table 8). The secretive behavior of Henslow's sparrow and its short and nondescript song make this bird one of the most difficult breeding birds in the Valley to observe.

Habitat: Restricted during the breeding season to several grassland communities. Primary use is made of retired agricultural fields that have developed a rank growth of vegetation, primarily timothy and various forbs. Managed Grasslands maintained for duck production provide important nesting habitat, especially when vegetation height exceeds $0.5 \mathrm{~m}$. Occasional use is made of alfalfa fields and tame pastures or thick grassland vegetation associated with the periphery of seasonally and semipermanently flooded wetlands.

\section{Sharp-tailed Sparrow (Ammospiza caudacuta)}

Status: Casual migrant and summer resident.

Migration: Three spring and one fall migration records exist for the Valley including 19 May 1964, St. Croix County; 8 May 1974, Pierce County (Faanes and Goddard 1976); and 23 May 1976, Burnett County (Crex Meadows). One bird was observed in St. Croix County on 18 August 1977. Because of the secretive habits of this species, and its extremely highpitched song, the sharp-tailed sparrow is probably more common than records indicate.

Nesting Season Distribution: The sharp-tailed sparrow has been recorded at Crex Meadows, Burnett County, on at least five occasions during the nesting season. The first record was of one singing male on 21-22 July 1969. On 31 July and 1 August 1970, one singing male was recorded in the same area. It was not until 13 August 1975 that T. C. Baptist again recorded this sparrow in the same marsh. Tessen (1978) reported observing at least three singing males on 28 and 29 May 1977. Later, on 10 June 1977, I recorded one singing male at the same location. All Crex Meadows observations during the breeding season were made in a large sedge meadow in Sec. 15, T. 39 N., R. 18 W. Because of the territorial behavior exhibited by these birds, sharp-tailed sparrows can be considered a probable breeding species at Crex Meadows.

Habitat: The area that sharp-tailed sparrows occupy at Crex Meadows is an extensive Northern Sedge Meadow that is characterized by manna grass, bluejoint grass, and water sedge. Although habitat similarities exist between sharp-tailed and LeConte's sparrow at Crex Meadows, apparently sharp-tailed sparrows choose moister areas in the meadow.

\section{Vesper Sparrow (Pooecetes gramineus)}

Status: Regular migrant and nesting species. 
Migration: Common spring and fall migrant in the Western Upland and Central Plain, uncommon and more local in the Northern Highland. Spring migrants arrive in the Western Upland 5-10 April (earliest-25 March 1963, St. Croix County) and the Northern Highland 10-15 April. Peak spring migration through the Valley occurs 15 April to 1 May. Peak fall migration occurs 1-20 September and departure by 15 October.

Nesting Season Distribution: Common nesting species in the Western Upland and Central Plain, uncommon in the Northern Highland. Erickson (1937), however, considered it abundant in Pine County. Breeding Bird Survey data (Table 8) suggest that the vesper sparrow is the second most abundant nesting sparrow in the Valley. Jackson (1943) reported that the vesper sparrow was a common breeding bird throughout most of northwestern Wisconsin in 1919.

Habitat: Characteristic nesting species of edge situations including fencerows adjoining agricultural fields and the border of retired cropland with deciduous forest. Brushy highway rights-of-way and Old Field Communities are regularly used in the Western Upland and Central Plain. Breeding vesper sparrows in northern regions occur in open areas, brushy fields, or occasionally in openings in Jack Pine Barrens.

\section{Lark Sparrow (Chondestes grammacus)}

Status: Regular migrant and summer resident.

Migration: Rare spring and fall migrant in the Western Upland and Central Plain, absent from the Northern Highland except in the region near Grantsburg. Burnett County. Spring migration dates occur during a narrow range from 10-25 May. Fall migration dates range from 1-15 September.

Nesting Season Distribution: The only evidence of possible breeding in the Valley is available from the Union BBS transect in Burnett County. S. D. Robbins found a small breeding "colony" of lark sparrows near Grantsburg on 26 June 1975. Since then, up to five singing males have been recorded in that location each year, but no nests of young have yet been found. Green and Janssen (1975) showed that the breeding range of this sparrow in Minnesota includes Chisago, Washington, and southern Pine counties. S. D. Robbins (personal communication) observed lark sparrows near Cushing, Polk County, on 22 June 1977 and near North Hudson, St. Croix County, on 8 July 1965. During June 1977 I observed a group of five lark sparrows in St. Croix County (Sec. 22, T. 30 N., R. 18 W.). The appearance of two of these birds suggested that they were young of the year. Kemper (1973) considered this species rare in Chippewa and Eau Claire counties, $120 \mathrm{~km}$ east of the St. Croix County location.

Habitat: Lark sparrows at the Burnett County location use an open area in mixed bur oak-jack pine. The St. Croix County location was characterized by the brushy edge of a Managed Grassland. 


\section{Dark-eyed Junco (Junco hyemalis)}

Status: Regular migrant, nesting species, and winter resident.

Migration: Abundant migrant throughout the Valley. Determination of arrival of spring migrants in the Western Upland and Central Plain is confounded by wintering birds. The first noticeable influxes occur 1-15 March. First spring migrants arrive in the Northern Highland 15-30 March. Peak spring migration through the Valley occurs 30 March to 15 April and departure from nonbreeding areas by 15 May. Fall migration begins in the Northern Highland during early September. First migrants arrive in the Western Upland 15-25 September. Peak fall migration occurs during October and most nonwintering birds have departed by 1 December.

Nesting Season Distribution: Rare nesting species, restricted to the Northern Highland. Roberts (1932) reported young being fed in Pine County during late June 1918, the first breeding record for the Valley. Two young dark-eyed juncos were observed in Chisago County on 16 June 1950 (Warner 1951). Breeding Bird Survey data (Table 8) also suggest that the breeding population of this species is rather limited in the Valley. An adult that I observed near Deer Park, St. Croix County, on 23 June 1976 was extralimital and probably an extremely late migrant.

Winter: Common (locally abundant) winter resident along the lower St. Croix River in Pierce, St. Croix, and southern Washington counties. Rare and local in the Central Plain, occasional in the Northern Highland. Christmas Bird Count data (Table 4) show the rapid decrease in relative abundance of this species moving north through the Valley during the winter. Darkeyed juncos are well known for their attachment to the numerous winter feeding stations in residential areas.

Habitat: Primarily a species of drier upland habitats including Jack Pine Barrens and mixed Northern Hardwood Forest. Roberts (1932) mentioned that nesting dark-eyed juncos are also associated with "spruce and cedar swamps of the lowlands" in Pine County. Wintering dark-eyed juncos make extensive use of edge habitats, particularly hedgerows, and to a lesser extent several deciduous forest types, primarily Southern Deciduous Forest and Lowland Deciduous Forest.

\section{Tree Sparrow (Spizella arborea)}

Status: Regular migrant and winter resident.

Migration: Abundant migrant throughout the Valley. Fall migrants arrive in the Northern Highland 5-10 October and in the Western Upland 10-15 October. Peak fall migration occurs 25 October to 25 November and departure of most nonwintering birds occurs by 30 November. Spring migrants arrive in the Northern Highland 1-10 April. Peak spring migration throughout the Valley occurs 10-20 April and departure by 30 April; occasional stragglers linger through 15 May.

Winter: Fairly common (locally common) winter resident in the Western Up- 
land, rare and local in the Central Plain. Christmas Bird Count data (Table 4) suggest that highest winter populations occur in areas directly adjacent to the lower St. Croix River. Populations decrease rapidly in areas northward from the Central Plain. The tree sparrow has not been recorded on the Solon Springs CBC, Douglas County.

Habitat: During migration, the tree sparrow uses a variety of open habitats including agricultural fields, retired cropland, and wetland edges. During midwinter, extensive use is made of retired croplands that support dense weedy patches. Grassy openings in Southern Deciduous Forest and occasional remnant prairie patches occurring along the river bluffs are also important.

\section{Chipping Sparrow (Spizella passerina)}

Status: Regular migrant and nesting species.

Migration: Common migrant throughout the Valley. Spring migrants arrive in the Western Upland 10-15 April (earliest-3 April 1971, Washington County) and reach the Northern Highland about 15-20 April. Peak spring migration through the Valley occurs 1-15 May. Peak fall migration occurs 10 September to 1 October and departure by 15 October (latest-3 November 1963, St. Croix County).

Nesting Season Distribution: Common nesting species throughout the Valley. Breeding Bird Survey data (Table 8 ) suggest that the largest breeding population occurs in the northern regions of the Central Plain and throughout the Northern Highland. Jackson (1943) reported that chipping sparrows were common nesting birds throughout northwestern Wisconsin. Goddard (1972) reported a density of 11.1 pairs per 40 ha in the Kinnickinnic River Valley, Pierce County.

Habitat: Primarily a nesting species of various coniferous habitats including Lowland Coniferous Forest, Black Spruce-Tamarack Bogs, and Jack Pine Barrens. In residential areas, this sparrow is common in ornamental shrubs. Breeding pairs are occasionally encountered in brushy margins between Lowland Deciduous Forest and open fields. Jackson (1943) described a chipping sparrow nest at St. Croix Falls that was $6.4 \mathrm{~m}$ above ground in a large white pine.

\section{Clay-colored Sparrow (Spizella pallida)}

Status: Regular migrant and nesting species.

Migration: Fairly common migrant throughout the Valley. Spring migrants arrive in the Western Upland 25 April to 1 May and the Northern Highland 5-10 May (earliest-29 April 1961, Burnett County). Peak spring migration through the Valley occurs 10-20 May. Peak fall migration occurs 20 August to 5 September in the Northern Highland and 10-25 September elsewhere. Departure from the Northern Highland occurs about 20 September (latest16 October 1963, Burnett County) and the Western Upland 1-15 October. 
Nesting Season Distribution: Fairly common and local nesting species in all regions, probably most abundant in the Northern Highland (Table 8). Jackson (1943) reported that the clay-colored sparrow was a common nesting species at Danbury (Burnett County) and Solon Springs (Douglas County) in 1919. Clay-colored sparrows apparently become semicolonial where habitat is favorable.

Habitat: Primarily a species of edge situations including brushy fields. This species becomes numerous in recently burned areas or where there are relatively young conifer plantings. Commonly found associated with retired agricultural fields and Old Field Community where coarse perennial weeds have become established. In the Northern Highland, this species has responded favorably to intensive management for sharp-tailed grouse on sandy soils. Nests are usually found in association with sweet fern vegetation in areas of restored native prairie. Nesting clay-colored sparrows near the mouth of the Kinnickinic River in Pierce and Washington counties are associated with brushy open areas in Southern Deciduous Forest.

\section{Field Sparrow (Spizella pusilla)}

Status: Regular migrant and nesting species, casual early winter resident.

Migration: Fairly common to common migrant throughout the Valley. Locally distributed in heavily forested regions of the Northern Highland. Spring migrants arrive in the Western Upland about 10-20 April and the Northern Highland by 1 May. Peak spring migration through the Valley occurs late April to 15 May. Fall migration begins in the northern regions in late August and departure is by 15 September. Peak fall migration through the lower Valley occurs during 15-25 September and departure by $15 \mathrm{Oc}$ tober.

Nesting Season Distribution: Fairly common and well-distributed nesting species in the Western Upland and Central Plain. Rare (locally common) nesting species in the Northern Highland. Bernard (1967) considered this sparrow a rare summer visitor and possible resident in Douglas County. Breeding Bird Survey data (Table 8) suggest that the field sparrow occurs fairly regularly during the nesting season in southern Douglas County. Roberts (1932) credited the removal of coniferous forest and replacement with a deciduous forest type with the expansion of this sparrow northward along the St. Croix River to southern Pine County.

Winter: Three winter records for St. Croix County from the Afton CBC, including single birds on 1 January 1971 and 1973, and three birds in one group on 1 January 1978. It is not known if any of these birds survived the winter. When the location of the 1978 birds was rechecked on 12 January 1978 , the birds were not found.

Habitat: Characteristic nesting species of the Old Field Community where it is associated with early successional species including box elder, trembling aspen, staghorn sumac, and chokecherry. Use is also made of well-established growths of various coarse weeds in retired agricultural fields. During early stages of development, field sparrows are regularly encountered in 
Pine Plantations. Deciduous Clear Cuts and brushy openings in Jack Pine Barrens are used in the Northern Highland.

\section{Harris' Sparrow (Zonotrichia querula)}

Status: Regular migrant, one winter record.

Migration: Rare spring and uncommon fall migrant in the Western Upland and Central Plain, casual in the Northern Highland. Spring migrants arrive in the Western Upland 1-5 May and are most frequently observed 10-20 May, departing by 25 May. Fall migrants arrive 20 September to 1 October. Peak fall migration occurs 10-20 October and departure by 30 October (latest-2 November 1968, St. Croix County).

Winter: One bird was recorded on the Afton CBC (Washington County) on 1 January 1974 (Eckert 1974). On 4, 8, and 11 April 1967 S. D. Robbins observed one at Roberts, St. Croix County, that he suspected of overwintering somewhere in the area.

Habitat: Primarily a species of brushy edges of fields and hedgerows. $\mathrm{Ob}$ servations of Harris' sparrows indicate that they migrate in close association with white-crowned sparrows.

\section{White-crowned Sparrow (Zonotrichia leucophrys)}

Status: Regular migrant, one winter record.

Migration: Uncommon migrant throughout the Valley. Spring migrants arrive in the Western Upland 25 April to 1 May (earliest-2 April 1961, St. Croix County), reaching the Northern Highland 1-5 May (earliest-20 April 1954, Burnett Countyl. Peak spring migration occurs 10-25 May and departure by 30 May (latest-11 June 1953, Burnett County; Besadny 1953). Fall migrants arrive 5-10 September. Peak fall migration occurs 15-20 September and departure 25 September to 10 October.

Winter: One white-crowned sparrow was observed at a feeder in Luck, Polk County, on 23 December 1957 (Lound and Lound 1958b).

Habitat: Edges of deciduous woods that support a brushy understory, brushy edges of retired agricultural fields, hedgerows, and ornamental plantings in residential areas.

\section{White-throated Sparrow (Zonotrichia albicollis)}

Status: Regular migrant, nesting species, and winter resident.

Migration: Abundant migrant throughout the Valley. The white-throated sparrow is second only to the song sparrow in abundance during migration. Spring migrants arrive in the Western Upland 1-10 April and the Northern Highland by 15 April. Peak spring migration occurs 20 April to 10 May and departure from nonbreeding areas occurs by 25 May. Fall migration begins in the Northern Highland in late August and the first birds reach the West- 
ern Upland 5-10 September (earliest-25 August 1977, Pierce County). Peak fall migration occurs 15 September to 10 October. Departure from the Northern Highland occurs 10-20 October and elsewhere by 15 November.

Nesting Season Distribution: Common nesting species in the Northern Highland (Table 8), uncommon and local in the Central Plain. Green and Janssen (1975) showed that the breeding range of this sparrow extended south to the Chisago-Washington County line. My most southerly nest record was obtained on 9 June 1975, near Luck, Polk County (Sec. 19. T. 36 N., R. 17 W.).

Winter: Rare and regular winter resident in the Western Upland. Usually encountered each year on either the Afton or Suburban St. Paul CBC. One remained at St. Croix Falls, Polk County, during the 1949-50 Winter.

Habitat: The white-throated sparrow occupies both deciduous and coniferous habitats during the nesting season. There is no single habitat that can be considered characteristic. Deciduous habitats that are most regularly used include stands of mature Northern Hardwood Forest with sugar maple, basswood, and silver maple the predominant vegetation. Nests in this habitat are usually associated with lush grasses and forbs in the ground layer. Deciduous Clear Cuts $<10$ years old and predominantly trembling aspen with scattered patches of black raspberry are an important deciduous habitat. Coniferous habitats of major importance include Lowland Coniferous Forest dominated by yellow birch, white cedar, black spruce, and balsam fir. Extensive use is also made of Black Spruce-Tamarack Bogs. Use of Jack Pine Barrens is very low and irregular.

\section{Fox Sparrow (Passerella iliaca)}

Status: Regular migrant, casual early winter resident.

Migration: Fairly common migrant throughout the Valley. Spring migrants arrive in the Western Upland 15-25 March and the Northern Highland 1-5 April. Peak spring migration occurs 10-25 April and departure by 15 May (latest-28 May 1972, Washington County). Fall migrants arrive 10-15 September, peak fall migration occurs 1-20 October, and departure is by 15 November.

Winter: There are several early winter records from the Western Upland. These records include 13 December 1968, Chisago County, and 2 January 1960, 1 January 1970, 1974, and 1976 on the Afton CBC, Washington County.

Habitat: In the Western Upland, the fox sparrow is primarily a species of Southern Deciduous Forest characterized by white, Hill's, and bur oak. Extensive areas of brushy understory, primarily prickly ash, hazelnut, and beaked hazel are important components of that habitat. In the northern regions, fox sparrows use brushy edges and heavy undergrowth in Northern Hardwood Forest, primarily quaking aspen, sugar maple, basswood, white birch, and green ash. 


\section{Lincoln's Sparrow (Melospiza lincolnii)}

Status: Regular migrant and possible summer resident.

Migration: Uncommon spring and fairly common fall migrant throughout the Valley, locally common in the Northern Highland. Spring migrants arrive in the Western Upland 1-5 May and the Northern Highland 5-10 May. Peak spring migration through the Valley occurs 10-20 May and departure 25 May to 1 June. Fall migration begins in the Northern Highland about 15 August with the first arrivals in the Western Upland 20-25 August. Peak fall migration occurs 15 September to 10 October and departure by 15-20 October (latest-28 October 1963, St. Croix County).

Nesting Season Distribution: S. D. Robbins (personal communication) recorded single Lincoln's sparrows along the route of the Minong BBS (Douglas County) on 16 June 1971 and 27 June 1975. On 26 June 1974 Robbins recorded one in an open bog about $6.4 \mathrm{~km}$ north of Moose Junction, Douglas County.

Habitat: Migrant Lincoln's sparrows are usually associated with brushy edge habitats. Old Field Community, retired agricultural fields, and ornamental shrubbery in residential areas are important among these. In the Northern Highland, this sparrow is regularly encountered in wet coniferous habitats, brushy borders of Northern Sedge Meadow, and in Alder Thickets.

\section{Swamp Sparrow (Melospiza georgiana)}

Status: Regular migrant and nesting species, one winter record.

Migration: Common migrant throughout the Valley. Spring migrants arrive in the Western Upland 25 March to 5 April and the Northern Highland 15-20 April. Peak spring migration through the Valley occurs 20 April to 5 May. Peak fall migration occurs 15 September to 10 October and departure by 20 October.

Nesting Season Distribution: Uncommon to fairly common nesting species in the Central Plain and Northern Highland, locally in the Western Upland. Jackson (1943) found the swamp sparrow "never particularly common" during the 1919 nesting season. He found nests with young at St. Croix Falls (Polk County) and Solon Springs (Douglas County). Breeding Bird Survey data (Table 8 ) suggest that the swamp sparrow is more abundant during the nesting season in the northern regions of the Central Plain and throughout the Northern Highland.

Winter: A single bird was observed in St. Croix County during the Afton CBC on 1 January 1970.

Habitat: Characteristic nesting species of Alder Thicket and Northern Sedge Meadow habitats in northern regions. Also fairly regular in Black Spruce-Tamarack Bogs and in open leatherleaf-Labrador tea bogs. In the Central Plain, this sparrow breeds regularly in Shrub Carr habitat which is dominated by heavy growths of gray dogwood and in cattail-bulrush vege- 
tation associated with seasonally, semipermanently, and permanently flooded wetlands.

\section{Song Sparrow (Melospiza melodia)}

Status: Regular migrant, nesting species, and winter resident.

Migration: Abundant migrant throughout the Valley. Spring migrants arrive in the Western Upland $20 \mathrm{March}$ to 1 April and the Northern Highland 1-10 April (earliest-13 March 1954, Burnett County). Peak spring migration occurs 15 April to 1 May. Peak fall migration is 1-10 September in the Northern Highland and 25 September to 10 October in the Western Upland. Departure from the Northern Highland occurs 15-25 October (latest-16 November 1975, Burnett County) and elsewhere by 5 November.

Nesting Season Distribution: Common nesting species throughout the Valley. Breeding Bird Survey data (Table 8) suggest that the song sparrow is the most abundant breeding sparrow in the Valley. Jackson (1943) reported that the song sparrow was a common nesting bird "at every locality visited" in northwestern Wisconsin in 1919. Goddard (1972) reported a breeding density of 40.3 pairs per 40 ha in the lower Kinnickinnic River Valley, Pierce County. Goddard also reported that the song sparrow was the second most abundant breeding bird among 82 species nesting in that valley.

Winter: Regularly occurring species during winter along the lower St. Croix River. Most birds are associated with feeding stations in residential areas.

Habitat: Nearly unrestricted in nesting habitat use. Important habitats are Shrub Carr. Alder Thicket, Prairie Wetlands, retired agricultural fields, Old Field Community, highway rights-of-way, and brushy openings in upland deciduous forest. Coniferous habitats are used to a lesser degree. Important among these are Black Spruce-Tamarack Bog and Lowland Coniferous Forest.

\section{Lapland Longspur (Calcarius lapponicus)}

Status: Regular migrant and winter resident.

Migration: Abundant migrant in the Western Upland, Central Plain, and unforested regions of the Northern Highland; rare in the heavily forested regions of the Northern Highland. Fall migrants arrive in the Northern Highland 15-20 September and the Western Upland 25 September to 1 October. Peak fall migration occurs 15 October to 15 November and most have departed by 1 December. Spring migrants arrive in the Western Upland 1-5 March and the Northern Highland about 15 March. Peak spring migration occurs 20 March to 10 April and departure by 10 May.

Hobitat: An open country bird using primarily heavily grazed tame pasture, fall plowed agricultural fields, corn and oat stubble, and the exposed edges of Prairie Wetlands.

Winter: Uncommon winter resident of the Western Upland and Central 
Plain, usually absent north of St. Croix Falls. Normal winter flock size is 10-30. The largest daily total on a CBC (Afton) is 174 on 1 January 1968.

\section{Chestnut-collared Longspur (Calcarius ornatus)}

Status: Accidental, one record.

Record: K. H. Dueholm observed three chestnut-collared longspurs in a flock of lapland longspurs on 20 March 1976, $4.8 \mathrm{~km}$ north of Star Prairie, Polk County.

\section{Snow Bunting (Plectrophenax nivalis)}

Status: Regular migrant and winter resident.

Migration: Common (locally abundant) migrant in the Western Upland, Central Plain, and unforested regions of the Northern Highland. Fall migrants arrive in the Northern Highland $10-20$ October (earliest-5 October 1952, Burnett County) and the Western Upland 20-30 October. Peak fall migration occurs 10 November to 1 December. Peak spring migration occurs 1-15 March and departure by 15 April (latest-30 April 1971, Burnett County).

Winter: Fairly common (locally common) winter resident in the unforested areas of the Valley. Christmas Bird Count data suggest that largest numbers occur in the Central Plain and Northern Highland. The largest group on record $(2,500)$ was recorded by N. R. Stone at Crex Meadows, Burnett County, on 21 December 1950.

Habitat: Primarily a species of open country using heavily grazed tame pasture, fall plowed agricultural fields, and corn or oat stubble. In the Northern Highland, occasional use is made of grassy railroad rights-of-way that traverse extensive hardwood forest stands.

\section{Acknowledgments}

This report has been greatly enhanced by the observations and contributions of many birders and ornithologists too numerous to mention individually. The entire manuscript benefited from critical reviews by $D$. R. Bystrak, J. C. Green, C. S. Robbins, S. D. Robbins, and D. D. Tessen. Individual sections of the manuscript were critically reviewed by B. A. Moss (waterfowl), K. H. Dueholm, and J. W. Richardson (habitats). Additional suggestions and comments on various portions of the manuscript were provided by H. F. Duebbert, C. L. Henderson, R. L. Hine, D. H. Johnson, H. A. Kantrud, and R. L. Kologiski. Publication of these data was originally proposed by E. Lanis.

The staff of the Northern Prairie Wildlife Research Center contributed in many ways. R. L. Duval and C. W. Shaiffer prepared the figures. E. K. Bartels provided extensive bibliographic support. 


\section{References}

American Ornithologists' Union. 1957. Check-list of North American birds. Fifth edition. Am. Ornithol. Union, Baltimore. $691 \mathrm{pp}$.

American Ornithologists' Union, 1973. Thirty-second supplement to the American Ornithologists' Union check-list of North American birds. Auk 90(2):411-419.

American Ornithologists' Union. 1976. Thirty-third supplement to the American Ornithologists' Union check-list of North American birds. Auk 93(4):875-879.

Anonymous. 1939. Spread of the starling in Wisconsin. Passenger Pigeon 1(10):139-141, 143 .

Arbib, R. 1978. The blue list for 1979. Am. Birds 32(6):1106-1113.

Barger, N. R. 1942. January field notes. Passenger Pigeon 4(1):18.

Bauers. H. A. 1964. Autumn season. Passenger Pigeon 26(3):143-155.

Beimborn, D. 1969. Bird species and the tension zone. Passenger Pigeon 32(2):49-51.

Bent, A. C. 1953. Life histories of North American wood warblers. U.S. Natl. Mus. Bull. 203. 734 pp.

Bernard, R. F. 1967. The birds of Douglas County, Wisconsin. Passenger Pigeon 29(2):3-36.

Bernard, R., and B. Klugow. 1963. Hawk owls invade Wisconsin. Passenger Pigeon 25(2):47-50.

Besadny, C. D. 1953. I ate spring and summer season. Passenger Pigeon 15(4):174-181.

Binder, E. 1979. Rufous hummingbird at Hastings. Loon 51\{1\}:14.

Bratlie, B. 1976. Acadian flycatcher sighting and winter wren nesting at Franconia. Loon 48(4):187-188.

Britton, N. L., and A. Brown. 1913. An illustrated flora of the northern United States and Canada. Charles Scribner and Sons Inc., New York. 3 vois.

Bystrak, D. 1979. The breeding bird survey. Sialia 1:74-79, 87.

Caldwell, H. 1968. Summer tanager observation. Passenger Pigeon 30(3):126.

Chambers, A. 1944. Minnesota nesting records, 1943. Flicker 16(1):10-14.

Christenson, G., and M. R. Fuller. 1975. Food habits of two long-eared owl families in east-central Minnesota. Loon 47(1):58-61.

Cooper, J. A., and M. A. Johnson. 1977. Wintering waterfowl in the Twin Cities. Loon 49(3):121-138.

Cowardin, I. M., V. Carter, F. C. Golet, and E. T. LaRoe, 1979. Classification of wetlands and deepwater habitats of the United States. U.S. Fish Wildl. Serv., Biol. Surv. Program, FWS/OBS 79/31. 103 pp.

Curtis, J. T. 1959. The vegetation of Wisconsin. University of Wisconsin Press, Madison. $657 \mathrm{pp}$.

Fckert, K. R. 1971. The summer season. Loon 43(4):114-119.

Eckert, K. R. 1974. The winter season Dec. 1973-Feb. 1974. Loon 46131:104-112.

Eckert, K. R. 1975. The summer season (June 1-July 31, 1974). Loon 4711):25-38.

Eckert, K. R. 1976. The summer season (June 1-July 31, 1975). Loon 48(1):14-28.

Eckert, K. R. 1978. Invasion of great gray and boreal owls, winter 1977-78. Loon $50(2): 63-68$.

Eckert, K. R. 1979. Western Great Lakes Region. Am. Birds 33(5):772-775.

Edgar, M. 1943. Tufted titmouse nesting in Minnesota. Flicker 15(3):35.

Eillarson, K.S. 1950. The yellow-headed blackbird in Wisconsin. Passenger Pigeon 12(3):99-109.

Erdman, T. C. 1970. Current migrant shrike status in Wisconsin. Passenger Pigeon 32(4): $144-150$.

Erickson, A. B. 1937. Birds of Hinckley. Flicker 9(1):6. 8.

Erickson, A. B., and R. Upson. 1938. 1938 Minnesota nesting records. Flicker 10(1):4-13.

Evans, D. L. 1975. Fall owl migration at Duluth, Minnesota. Loon 47(2):56-58.

Evrard, J. O. 1975. Nesting great egrets in Burnett County. Passenger Pigeon $37(4): 151-152$.

Evrard. J. O., E. A. Lombard, and K. H. Larsen. 1978. 'esponse to drought by a hreeding population of common loons. Passenger Pigeon $+1(2): 41 \mathrm{~K}$. 
Faanes, C. A. 1975). A northern three-toed woodpecker in Polk County. Passenger Pigeon 37(3):135-136.

Faanes, C. A. 1979. Status of the black tern in western Wisconsin. Passenger Pigeon $41(3): 124-128$.

Faanes, C. A., and S. V. Goddard. 1976. The birds of Pierce and St. Croix Counties, Wisconsin. Passenger Pigeon 38(1):19-38, 38(2):57-71.

Feeney, W. S. 1942. The spring season. Passenger Pigeon 4|31:50-53.

Follen, D. G.. Sr. 1979. A probable breeding record of great-gray owls in Wisconsin. Passenger Pigeon 41(2):53-57.

Foster, B. 1956. Autumn season. Passenger Pigeon 18111:31-44.

Garber, B. 1965. Wisconsin's third green-tailed towhee. Passenger Pigeon $27(1): 12-13$.

Glassel. R. C. 1977. Kentucky warbler in Washington County. Loon 49(4):242-243.

Gleason. H. A., and A. Cronquist. 1963. Manual of vascular plants of northeastern United States and adjacent Canada. Van Nostrand Co., Princeton, N.J.810 pp.

Goddard, S. V. 1972. Comparison of breeding bird populations of the lower Kinnickinnic River Valley, Passenger Pigeon 34(3):91-95.

Goddard, S. V. 1975. Spring waterfowl utilization of western Wisconsin wetlands. Passenger Pigeon 37(1):32-44.

Goddard, S. V. 1976. A Baird's sparrow in Burnett County. Passenger Pigeon $38(1): 52$.

Green, J. C. 1963 . Hawk owl invasion, winter 1962-63. Flicker 35ł3ł:77-78.

Green. J. C. 1967. Gray jay invasion, fall 1965. Loon 3911::22-23.

Green, J. C. 1969. Northern Owl invasion, winter 1968-69. Loon 4l(2):36-39.

Green, J. C. 1979. The summer season (June 1--July 31, 1978). Loon 5111):28-44.

Green, J. C., and J. A. Baumhoffer. 1972. The 1972 summer season. Loon 44(4):105-111.

Green, J. C., and R. B. Janssen. 1975. Minnesota birds. University of Minnesota Press, Minneapolis. 217 pp.

Gromme, O. J. 1941. Several interesting breeding records secured. Passenger Pigeon $3(8): 71-72$.

Hamerstrom, F.. and F. Hamerstrom. 1963. Range of the red-bellied woodpecker in Wisconsin. Passenger Pigeon 25(4):131-136.

Henderson, C. I. 1978. Results of an observation card survey for sandhill cranes in Minnesota for 1977. Loon 50121:112-118.

Herz. J. D. 1954. Minnesota nesting season-1953. Flicker 26(2):66-73.

Hilsenhoff, W. I. 1966. Winter season. Passenger Pigeon 2844\}:154-163.

Hofslund, P. B. 1952. Winter wrens nesting at Solon Springs, Wisconsin. Passenger Pigeon 14(2):82.

Hofslund, P. B., and G. J. Niemi. 1977. Mississippi kite (Jctinia mississippiensis) sighted at Crex Meadows. Passenger Pigeon 3911):204.

Honetschlager, D. 1963. Cinnamon teal seen near Stillwater. Flicker 35(2):66.

Honetschlager, D. 1974. Gyrfalcon sighting. Loon 46(2):89-90.

Honetschlager, D. A. 1965. Black-backed three-toed woodpecker in Washington County. Loon 37(1):49.

Huber, R. L. 1962. The spring season. Flicker 34(2):50-58.

Huber, R. L. 1965. Catbird in late December. Loon 37(1):48.

Huber. R. L. 1967. The summer season. Loon 39(4):122-131.

Huber, R. L. 1974a. More black-headed grosbeak records. Loon 46(3):117.

Huber, R. L. 1974h. Black-backed three-toed woodpecker in Washington County. Loon 46(3):127.

Hubert, B. 1945. Prothonotary warblers. Flicker 17(4):91.

Hunt, R., and L. Jahn. 1958. A cinnamon teal on Crex Meadows. Passenger Pigeon 20(4):179-180.

Jackson, H. H. T. 1941. The summer birds of northwestern Wisconsin. Passenger Pigeon 3:87-90, 95-98, 103-106.

Jackson, H. H. T. 1942. The summer birds of northwestern Wisconsin. Passenger Pigeon 4:9-12, 37-39, 91-95.

Jackson, H. H. T, 1943. The summer birds of northwestern Wisconsin. Passenger Pigeon 5:24-35. 
Jackson, N. A. 1970. Nesting red crossbills, Washington Co. Loon 42(4):144.

Jehl. J. R., Jr. 1968, Relationships in the Charadrii, a taxonomic study based on color patterns of downy young. San Diego Soc. Nat. Hist. Mem. No. 3.54 pp.

Johnson, J. 1976. Distribution of sandhill crane in Minnesota. Proc. Int. Crane Workshop 1:59-68.

Kemper. C. A. 1961. Autumn season. Passenger Pigeon 23(2):66-74.

Kemper, C. A. 1965. Autumn season. Passenger Pigeon 27(3):120-127.

Kemper, C. A. 1973. Birds of Chippewa, Eau Claire, and neighboring counties. Passenger Pigeon 35(2):55-91, 35(3):107-129.

King, F. H, 1949. The American egret in Wisconsin. Passenger Pigeon 11(1):3-17.

Knudson, G. J. 1978. Letter to the editor. Passenger Pigeon 40(4):519.

Kratz, T. K., and G. L. Jensen. 1977. An ecological geographic division of Minnesota. Minnesota Department of Natural Resources. St. Paul. 24 pp. (mimeo)

Kumlien, L., and N. Hollister. 1951. The birds of Wisconsin. Wisconsin Society for Ornithology, Madison. $122 \mathrm{pp}$.

Larson, N. 1970. Crossbills and siskins in Chisago County. Loon 42(4):144.

Les. B. L. 1979. The vanishing wild. Wisconsin Department of Natural Resources, Madison. 35 pp.

Lesher, F. 1976. The autumn season. Passenger Pigeon 38(3):112-125.

Lien, B., and H. Lien, compilers, 1977. Afton, Minnesota. Am. Birds 31(4):703.

Lindholm, G. F., J. O. Helgesen, W. I. Broussard, and D. F. Farrell. 1974. Water resources of the lower St. Croix River watershed, east-central Minnesota. U. S. Geol. Surv., Hydrologic Invest. Atlas HA-490.

Link, M. 1977. A natural and social history of Pine and Chisago Counties. Northwoods Audubon Center, Sandstone. $36 \mathrm{pp}$.

Litkey, B. 1969. Groove-billed ani record for Washington County. Loon 41(2):54.

Longley, W. H. 1947. Sabine's gull in Minnesota. Auk 64(1):146-147.

Longley, W. H. 1949. Common loons breeding near Saint Paul. Flicker 21(3):89.

Longley, W. H. 1967. A varied thrush in Chisago County. Loon 39(2):68-69.

Longley, W. H. 1973a. A Townsend's solitaire in Chisago County. Loon 45(2):66.

Longley. W. H. 1973h. The Louisiana waterthrush still nests in Chisago County. Loon 45(3):95.

Lound, M. and R. Lound. 1956a. Spring season. Passenger Pigeon 18(3):124-140.

Lound, M., and R. Lound. 1956b. Summer season. Passenger Pigeon 18(4):175-184.

Lound, M., and R. Lound. 1957a. The 1956 Christmas Bird Count. Passenger Pigeon 19(1):16-24.

Lound, M., and R. Lound. 1957b. The winter season. Passenger Pigeon 19(2):84-93.

Lound, M., and R. Lound. 1957c. Spring season. Passenger Pigeon 19(3):125-141.

Lound, M., and R. Lound. 1957d. Summer season. Passenger Pigeon 19(4):174-181.

Lound, M., and R. Lound. 1958a. Autumn season. Passenger Pigeon 20(1):29-45.

Lound, M., and R. Lound. 1958b. Winter season. Passenger Pigeon 20(2):80-89.

Ludwig. F. 1974. Minnesota's third gray-crowned rosy finch. Loon 46(2):82.

lupient. M. 1945. Minnesota nesting records, 1945. Flicker 17(4):82-88.

Iupient, M. 1952. Seasonal report. Flicker 24(4):119-121.

MacBriar, W. N., Jr. 1958. Spring season. Passenger Pigeon 20(3):121-136.

Marschner, F. J. 1930. Presettlement vegetation types in Minnesota (map). U.S. Department of Agriculture, Washington, D.C.

Martin, I. 1932. The physical geography of Wisconsin. Wis. Geol. Nat. Hist. Surv. Bull. 36.

Maurer, F. D. 1969. Worm-eating warbler seen, Loon 41131:89-90.

Maurer, R. 1970. Gnatcatchers in Washington County. Loon 42(4):145.

McCabe, K. A., and A. S. Hawkins, 1946. The Hungarian partridge in Wisconsin. Am. Midl. Nat. 3611:1-75.

Mettler, B. J. 1977. Factors contributing to the increase of the gray partridge in Minnesota. Loon 49(4):205-210.

Mierow, D. 1949. Minnesota nesting records, 1949. Flicker 21(4):101-114.

Moe, J. L. 1968. Winter distribution of red-headed woodpeckers in Wisconsin. Passenger Pigeon 30(2):72-74.

Monroe. B. L.., Jr. 1978. Summary of highest counts of individuals in Canada and the U.S. Am. Birds 32(4):924-930. 
Moyle, J. B. 1980. The uncommon ones: Minnesota's rare and endangered species. Minnesota Department of Natural Resources. St. Paul. 20 pp.

Olyphant, J.C. 1972. A Carolina wren's visit to Washington County. Loon $44(3): 89-90$.

Olyphant, J.C. 1973. Brewster's warbler banded in Washington County. Loon 45(3):99-100.

Olyphant, M. 1962. Hooded warbler banded in Washington County. Flicker 34(4):130.

Partch, M. 1970. Prairie chicken exodus: notes on the prairie chicken in central Minnesota. Loon 42\{1\}:5-19.

Peterson. A. J. 1951. The red-bellied woodpecker in Wisconsin. Passenger Pigeon $13\lfloor 1): 51-54$.

Peterson, L. R. 1978. Evaluation of waterfowl production units in Wisconsin. Wisconsin Dep. Nat. Resour., Job Prog. Rep. W-141-R-13. 31 pp.

Robbins, C. S., and W. T. Van Velzen. 1967. The breeding bird survey, 1966. U.S. Fish Wildl. Serv., Spec. Sci. Rep.-Wildl. 102.

Robbins, S. D. 1948a. The autumn season. Passenger Pigeon 10(1):33-39.

Robbins, S. D. 1948b. The winter season. Passenger Pigeon 10(2):79-84.

Robbins, S. D. 1948c. The spring season. Passenger Pigeon 10(3):116-123.

Robbins, S. D. 1949. The fall and early winter season. Passenger Pigeon 11(2):80-91.

Robbins, S. D. 1950a. The early spring season. Passenger Pigeon 12(3):136-143.

Robbins, S. D. $1950 b$. The late spring and summer season. Passenger Pigeon 12(4):171-183.

Robbins, S. D. 1961. Shorebirds in St. Croix County. Passenger Pigeon 23(2):63-64.

Robbins. S. D. 1963. The 1962 summer bird count. Passenger Pigeon 25(3):91-102.

Robbins, S. D. 1968. Shorebirds deluxe. Passenger Pigeon 30(1):31-32.

Robbins, S. D. 1969a. Fared grebe nests in Wisconsin. Passenger Pigeon 31(2):252

Robbins. S. D. 1969b. New light on the LeConte's sparrow. Passenger Pigeon 31(3):267-274.

Robbins, S. D. 1973. New light on the Cape May warbler. Passenger Pigeon 35(4):159-161.

Robbins, S. D. 1974a. New light on the Connecticut warbler, Passenger Pigeon $36(3): 110-115$.

Robbins, S. D. $1974 b$. The willow and alder flycatchers in Wisconsin: a preliminary description of summer range. Passenger Pigeon 36(4):147-152.

Robbins, S. D. 1977. The breeding bird survey in Wisconsin, 1966-1975. Passenger Pigeon 39(2):225-247.

Roberts, H., and N. Roberts. 1972. Summer season. Passenger Pigeon 34(2):74-81.

Roberts. T. S. 1932. The birds of Minnesota. University of Minnesota Press, Minneapolis. 2 vols.

Roberts. T. S. 1938. Logbook of Minnesota birdlife, 1917-1937. University of Minnesota Press. Minneapolis. $355 \mathrm{pp}$.

Russell, R. P., Jr. 1969. The summer season. I,oon 41(2):105-119.

Russell. R. P., Jr. 1970. The summer season. I.oon 42(2):129-135.

Savaloja. T. 1974. The spring season-March 1 to May 31. 1974. Loon 4644/:143-160.

Savaloja, T. 1977. The spring season-March 1 to May 31. 1977. Loon 49:211-227.

Schorger, A. W. 1943. The prairie chicken and sharp-tailed grouse in early Wisconsin. Trans. Wis. Acad. Sci. Arts Lett. 35:1-59.

Schorger. A. W. 1954. The white pelican in early Wisconsin. Pansenger Pigem $16(11: 136-140$.

Schorger, $A, W, 1955$. The passenger pigeon: its natural history and extinction. Uni. versity of Wisconsin Press. Madison. 424 pp.

Scott. W. F. 1943a. Townsend's solitaire reported at Hudson. Wisconsin. Passenger Pigeon 411):3.

Scott. W. F., 1943k. The Canada spruce grouse in Wisconsin. Passenger Pigeon 51(3):61 72 .

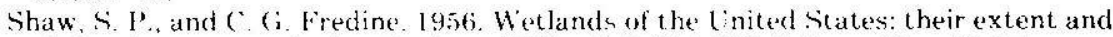
the ir value to waterfowl and other wildlife. U.S. Fish Wildl. Serv.. Circ. 39. $67 \mathrm{pp}$.

Simmons, O. T. 1919. Another varied thrush visits Wisconsin. Passenger Pigeon $11(1): 1: 3)-132$

Sindelar. ( 1971 . Wisconsin osprey survey. Passenger Pigeon 333(21:79-xk. 
Soulen, T. K. 1965. Spring season. Passenger Pigeon 27(1):24-47.

Southern, W. E. 1962. New breeding locality for LeConte's sparrow. Passenger Pigeon 22(1):28-29.

Sparkes, V. 1953. Minnesota nesting season-1952. Flicker 25(1):10-23.

Stewart. R. E. 1975. Breeding birds of North Dakota. Tri-College Center for Environmental Studies, Fargo, N.D. 295 pp.

Stone, N. R. 1957. A Baird's sparrow at Crex Meadows. Passenger Pigeon $19(3): 124-125$.

Stone, N. R. 1959a. Snowy egret at Crex Meadows. Passenger Pigeon 21(4):147.

Stone, N. R. 1959b. Three ivory gulls at Crex Meadows. Passenger Pigeon 21 (4):149.

Stone, N. R. 1967. Another straggler from the west. Passenger Pigeon 29(1):32-33.

Strelitzer, C. L. 1952. The spring season. Passenger Pigeon 14(4):113-121.

Surber, T. 1919. The Pine County game refuge as a playground. Fins, Feathers and Fur 18:1-4.

Tessen, D. D. 1969. The autumn season. Passenger Pigeon 31(4):285-301.

Tessen, D. D. 1977. Western Great Lakes Region. Am. Birds 31(5):1142-1146.

Tessen, D. D. 1978. Yellow rails and sharp-tailed sparrows at Crex Meadows. Passenger Pigeon 40(1):385-386.

Tessen, D. D. 1979a. Parasitic jaeger. Passenger Pigeon 41(1):47-48.

Tessen, D. D. 1979b. Western Great I akes Region. Am. Birds 33(5):864-866.

Thiel, R. P. 1978. The distribution of the three-toed woodpeckers in Wisconsin. Passenger Pigeon 40(4):477-488.

Turner, R. E. 1979. White pelicans migrating up the St. Croix River. I,oon 51(3):101.

Warner, D. W. 1951. The nesting season-1950. Flicker 23(1):1-8.

Waters, T. F. 1977. The streams and rivers of Minnesota. University of Minnesota Press, Minneapolis. $373 \mathrm{pp}$.

Willard, J. L. 1971. Possible summer mockingbird in Washington County. Loon $43(1): 24$.

Williams, R. J. 1957. The great blue heron colonies of Wisconsin. Passenger Pigeon $19(2): 51-66$.

Winkler, H. A. 1959. Winter season. Passenger Pigeon 21(3):121-128.

Wojahn, B. 1977. White-eyed vireo confirmed for Minnesota. Loon 49(3):174.

Young, H. 1961. The downy and hairy woodpeckers in Wisconsin. Passenger Pigeon 23(1):3-6.

Young. H. 1965. White-breasted and red-breasted nuthatches. Passenger Pigeon $27(1): 16-19$.

Young, H. 1967. The tufted titmouse. Passenger Pigeon 29(2):46-49.

Young, H., B. Stollberg, and M. Deusing. 1941. The spread of the cardinal through Wisconsin. Passenger Pigeon 3(1):1-4.

Young. H. L., and S. M. Hindall. 1973. Water resources of Wisconsin St. Croix River Basin. U.S. Geol. Surv. Hydrologic Invest. Atlas HA-45l. 


\section{Appendix A}

\section{Common and Scientific Names of Plants Mentioned in Text}

$\frac{\text { Species }}{\text { Alfalfa }}$

American elm

Arrowhead

Awned sedge

Awnless bromegrass

Balsam fir

Barley

Basswood

Beaked hazel

Bearberry

Big bluestem

Big-leaf aster

Bindweed

Bishop's cap

Black ash

Black cherry

Black raspberry

Black spruce

Black willow

Bladderwort

Bloodroot

Blue bead lily

Blue cohosh

Blue vervain

Blueberry

Bluejoint grass

Bog birch

Bog laurel

Bog rosemary

Bottle-brush grass

Box-elder

Bracken fern

Bristly sedge

Brome grass

Brown sedge

Buckbean

Bunchberry

Bur oak

Burreed

Canada bluegrass

Canada mayflower
Scientific name

Medicago sativa

Ulmus americana

Sagittaria latifolia

Carex atherodes

Bromus brizaeformis

Abies balsamea

Hordeum vulgare

Tilia americana

Corylus cornuta

Arctostaphylos uva-ursi

Andropogon gerardi

Aster macrophyllus

Convolvulus sepium

Mitella diphylla

Fraxinus nigra

Prunus serotina

Rubus occidentalis

Picea mariana

Salix nigra

Utricularia vulgaris

Sanguinaria canadensis

Clintonia borealis

Caulophyllum thalictroides

Verbena hasta

Vaccinium angustifolium

Calamogrostis canadensis

Betula glandulosa

Kalmia polifolia

Andromeda glaucophylla

Hystrix patula

Acer negundo

Pteridium aquilinum

Carex comosa

Bromus spp.

Carex buxbaumii

Menyanthes trifoliata

Cornus canadensis

Quercus macrocarpa

Sparganium eurycarpum

Poa compressa

Maianthemum canadense 


Species
Cane reed
Cattail
Choke cherry
Common elder
Common milkweed
Coontail
Corn
Cottongrass
Cottonwood
Creeping snowberry
Crested sedge
Daisy fleabane
Dark-green bulrush
Dogbane
Downy yellow violet
Dwarf ginseng
Elodea
Evening primrose
False Solomon's seal
Field mint
Flowering crab apple
Flowering spurge
Fox sedge
Foxtail sedge
Germander
Goat's beard
Goosegrass
Gray dogwood
Great water dock
Green ash
Ground pine
Hardstem bulrush
Hawthorn
Hazelnut
Hedge nettle
Hemlock
Hill's oak
Joary alyssum
Indian pipe
Inland sedge
Intermediate wheatgrass
Irinelweed

\begin{tabular}{l} 
Scientific Name \\
\hline Phragmites communis \\
Typha latifolia \\
Prunus virginiana \\
Sambucus canadensis \\
Aesclepias syriaca \\
Ceratophyllum demersum \\
Zea mays \\
Eriophorum angustifolium \\
Populus deltoides \\
Gaultheria hispidula \\
Carex cristatella \\
Erigeron strigosus \\
Scirpus atrovirens \\
Apocynum androsaemifolium \\
Viola pubescens \\
Panax trifolium \\
Anacharis nuttallii \\
Oenothera biennis \\
Smilacina stellata \\
Mentha arvensis \\
Pyrus spp. \\
Euphorbia corollata \\
Carex vulpinoidea \\
Carex alopecoidea \\
Teucrium canadense \\
Tragopogon pratensis \\
Galium aparine \\
Cornus racemosa \\
Rumex altissimus \\
Fraxinus pennsylvanica \\
Lycopodium clavatum \\
Scirpus acutus \\
Crategus spp. \\
Corylus americana \\
Stachys tenuifolia \\
Tsuga canadensis \\
Quercus hillii \\
Berteroa incana \\
Monotropa uniflora \\
Carex interior \\
Agropyron intermedium banksiana \\
Iris versicolor \\
Impatrya virginiana \\
\end{tabular}


Species

Kentucky bluegrass

Labrador tea

Large-flowered trillium

Large-toothed aspen

Leatherleaf

Little bluestem

Manna grass

Marsh bellflower

Marsh cinquefoil

Marsh milkweed

Marsh shield fern

Meadowsweet

Moth mullein

Mountain ash

Mountain holly

New Jersey tea

Noble goldenrod

Northern bedstraw

Oats

Partridge berry

Pearly everlasting

Pennsylvania sedge

Pickerelweed

Pitcher plant

Poison ivy

Prickly ash

Purple-stem aster

Quack grass

Ragweed

Rattlesnake fern

Rattlesnake grass

Red clover

Red maple

Red oak (Northern)

Red-osier dogwood

Red pine

Reed canary grass

Rice grass

River bulrush

Round-leaf sundew

Scotch pine

Sharp-toothed goldenrod

Sheep sorrel

Silver maple

Silver willow

Skunk cabbage

Slender sedge
Scientific name

Poa pratensis

Ledum groenlandicum

Trillium grandiflorum

Populus grandidentata

Chamaedaphne calyculata

Andropogon scoparius

Glyceria canadensis

Campanula aparinoides

Potentilla palustris

Asclepias syriaca

Dryopteris thelypteris

Spirea alba

Verbascum blattaria

Sorbus americana

Nemopanthus mucronata

Ceanothus ovatus

Salidago speciosa

Galium boreale

Avena sativa

Mitchella repens

Anaphalis margaritacea

Carex pennsylvanica

Pontederia cordata

Sarracenia purpurea

Toxicodendron radicans

Xanthoxylum americanum

Aster puniceus

Agropyron repens

Ambrosia spp.

Botrychium virginianum

Glyceria canadensis

Trifolium pratense

Acer rubrum

Quercus borealis

Cornus stolonifera

Pinus resinosa

Phalaris arundinacea

Oryzopsis asperifolia

Scirpus fluviatilis

Drosera rotundifolia

Pinus banksiana

Solidago juncea

Rumex acetosella

Acer saccharinum

Salix discolor

Symplocarpus foetidus

Carex lasiocarpa 
Species

Small bedstraw

Softstem bulrush

Solomon's seal

Soybean

Speckled alder

Sphagnum moss

Spikerush

Spotted joe-pye weed

Staghorn sumac

Starflower

Sugar maple

Sweet cicely (Jarvil)

Sweet fern

Switchgrass

Tall manna grass

Tamarack

Tartarian honeysuckle

Tick trefoil

Timothy

Toothwort

Trembling aspen

Turtlehead

Tussock sedge

Twisted stalk (Rose mandarin)

Virginia strawberry

Virginia waterleaf

Water horehound

Water milfoil

Water plaintain

Water sedge

Wheat

White ash

White birch

White cedar

White oak

White pine

White spruce

White waterlily

Whorled loosestrife

Wild cranberry

Wild cranesbill

Wild leek

Wild lettuce

Wild rice

Wild sarsaparilla

Wintergreen

\author{
Scientific Name \\ Galium trifidum \\ Scirpus validus \\ Polygonatum biflorum \\ Glycine max \\ Alnus rugosa \\ Sphagnum spp. \\ Eleocharis spp. \\ Eupatorium maculatum \\ Rhus typhina \\ Trientalis borealis \\ Acer saccharum \\ Osmorhiza claytoni \\ Comptonia peregrina \\ Panicum virgatum \\ Glyceria grandis \\ Larix laricinia \\ Lonicera tartarica \\ Desmodium glutinosum \\ Phleum pratensis \\ Dentaria laciniata \\ Populus tremuloides \\ Chelone glabra \\ Carex stricta \\ Streptopus roseus \\ Fragaria virginiana \\ Hydrophyllum virginicum \\ Lycopus virginicus \\ Myriophyllum spp. \\ Alisma plantago-aquatica \\ Carex aquatilis \\ Triticum aestivuum \\ Fraxinus americana \\ Betula papyrifera \\ Chamaecyparis thyoides \\ Quercus alba \\ Pinus strobus \\ Picea glauca \\ Nymphaea tuberosa \\ Lysimachia quadrifolia \\ Vaccinium macrocarpon \\ Geranium maculatum \\ Allium tricoccum \\ Lactuca canadensis \\ Zizania aquatica \\ Aralia nudicaulis \\ Gaultheria procumbens
}




\begin{tabular}{l} 
Species \\
\hline Wood anemone \\
Wood nettle \\
Yarrow \\
Yellow birch \\
Yellow waterlily \\
Yellowish sedge
\end{tabular}

\begin{tabular}{l}
\multicolumn{1}{c}{ Scientific Name } \\
\hline Anemone quinquefolia \\
Laportea canadensis \\
Achillea millefolium \\
Betula alleghaniensis \\
Nuphar variegatum \\
Carex abacta
\end{tabular}

\section{Bird Species Index}

Ani, Groove-billed, 84-85

Avocet, American, 23, 69

Bittern, American, 15, 16, 17, 18, 33-34

Least, 32-33

Blackbird, Brewer's, 151, 155-156

Red-winged, 13, 15, 16, 17, 18, 151, 153-154

Rusty, 155

Yellow-headed, 15, 151, 153

Bluebird. Eastern, 12, 18, 23, 108, 122-123

Bobolink, 17, 18, 150-151

Bobwhite, 23, 64

Brant, 35

Bufflehead, 47-48

Bunting, Indigo, 11, 12, 14, 18, 159, 160

Snow, 180

Canvasback, 45

Cardinal, 18, 93, 158, 159

Catbird, Gray, 12, 16, 18, 108, 117-118

Chat, Yellow-breasted. 148

Chickadee, Black-capped, 10, 11, 12, 13, 18, 93, 108, 110-111 Boreal, 111

Coot, American, 15, 68

Cormorant, Double-crested, 23, 28-29

Cowbird, Brown-headed, 12, 13, 14, 15, 16, 18, 151, 156-157

Crane, Sandhill, 16, 65-66

Creeper, Brown, 113-114

Crossbill, Red, 167

White-winged, 167-168

Crow, Common, 11, 14, 93, 108, 110

Cuckoo, Black-billed, 10, 84

Yellow-billed, 10, 84

Curlew, Long-billed, 71

Dickcissel. 17, 18, 23, 159, 160-161

Dove, Mourning, 14, 18, 83

Rock, 18, 21, 83

Dowitcher, Long-billed, 76

Short-billed, 75-76 
Duck, Black, 15, 23, 37-38, 49

Ring-necked, 15, 44.45

Ruddy, 15, 49-50

Wood, $10,15,42-43$

Dunlin, 78

Eagle, Bald, 23, 58-59

Golden, 58

Egret, Cattle, 31

Great, 23, 31-32

Snowy, 23, 32

Eider, Common, 48

Falcon, Peregrine, 23, 60-61

Finch, Gray-crowned Rosy, 163

Purple, 12, 13, 93, 159, 162-163

Flicker, Common, 10, 11, 14, 23, 91-93

Flycatcher, Acadian, 100

Alder, 9, 12, 16, 92, 101-102

Great Crested, 10, 11, 92, 98-99

Least, 10, 92,102

Olive-sided, 13, 103

Willow, 9, 16, 92, 100-101

Yellow-bellied, 13, 92, 100

Gadwall, 15, 38-39

Gallinule, Common, 68

Gnatcatcher, Blue-gray, 10, 123-124

Godwit, Hudsonian, 70-71

Marbled, 23, 71

Goldeneye, Barrow's, 47

Common, 47

Goldfinch, American, 12, 13, 18, 93, 159, 166-167

Goose, Canada, 15, 34-35

Snow, 36

White-fronted, 35-36

Goshawk, Northern, 53

Grackle, Common, 14, 151, 156

Grebe, Eared, 26-27

Horned, 26

Pied-billed, 15, 27-28

Red-necked, 25-26

Western, 27

Grosbeak, Black-headed, 160

Evening, 93, 161-162

Pine, 93, 163

Rose-breasted, $10,11,12,18,158-159$

Grouse, Ruffed, 10, 11, 12, 62-63

Sharp-tailed, 23, 64

Spruce, 23, 62

Gull, Bonaparte's, 80-81

Franklin's, 80 
Herring, 79

Ivory, 81

Ring-billed, 80

Sabine's, 81

Gyrfalcon, 60

Hawk, Broad-winged, 10, 56

Cooper's, 11, 23, 54

Ferruginous, 57-58

Marsh, 16, 17, 18, 23, 59

Red-shouldered, 10, 23, 55-56

Red-tailed, 11, 54-55

Rough-legged, 57

Sharp-shinned, 12, 53-54

Swainson's, 56-57

Heron, Black-crowned Night, 23, 32

Great Blue, 10, 15, 23, 29-30

Green, 15, 30

Little Blue, 30-31

Louisiana, 32

Yellow-crowned Night, 23, 32

Hummingbird, Ruby-throated, 12, 90-91

Rufous, 91

Jaeger, Parasitic, 79

Jay, Blue, 10, 11, 12, 14, 18, 92, 107-109

Gray, 107

Junco, Dark-eyed, 12, 93, 159, 173

Kestrel, American, 18, 61-62

Killdeer, 17, 69-70

Kingbird, Eastern, 12, 18, 92, 97-98

Western, 98

Kingfisher, Belted, 15, 91

Kinglet, Golden-crowned, 124

Ruby-crowned, 124-125

Kite, Mississippi, 52

Swallow-tailed, 52

Knot, Red, 76

Lark, Horned, 17, 103-104

Longspur, Chesnut-collared, 180

Lapland, 179-180

Loon, Common, 15, 23, 24-25

Red-throated, 25

Magpie, Black-billed, 109

Mallard, 15, 16, 17, 18, 36-37, 38, 49

Martin, Purple, 18, 92, 106-107

Meadowlark, Eastern, 18, 151, 152

Western, 17, 18, 151, 152

Merganser, Common, 50-51

Hooded, 15, 50

Red-breasted, 23, 51-52 
Merlin, 23, 61

Mockingbird, 117

Nighthawk, Common, 18, 89-90

Nuthatch, Red-breasted, 12, 13, 93, 108, 113

White-breasted, $10,11,18,93,108,112-113$

Oldsquaw, 48

Oriole, Northern, 10, 11, 14, 18, 151, 154-155

Orchard, 154

Osprey, 23, 59-60

Ovenbird, 10, 11, 12,13, 14, 130, 144

Owl, Barred, 10,87

Boreal, 88

Great Gray, 23, 87-88

Great Horned, 10, 11, 85

Hawk, 88

Long-eared, 85-86

Saw-whet, 88-89

Screech, 10, 18, 85

Short-eared, 23, 86

Snowy, 86-87

Partridge, Gray, 17, 65

Parula, Northern, 13, 136-137

Pelican, White, 23, 28

Pewee, Eastern Wood, 10, 11, 12, 92, 102-103

Phalarope, Northern, 74

Wilson's, 74

Pheasant, Ring-necked, 16, 18, 64-65

Phoebe, Eastern, 15, 99-100

Pigeon, Passenger, 83-84

Pintail, 15, 17, 18, 39

Pipit, Water, 125

Plover, American Golden, 70

Black-bellied, 70

Piping, 23, 69

Semipalmated, 69

Prairie Chicken, Greater, 8, 23, 63

Rail, King, 23, 66-67

Virginia, 15, 66

Yellow, 23, 67-68

Raven, Common, 10, 12, 93, 108, 109

Redhead, 43-44

Redpoll, Common, 93, 164-165

Hoary, 163-164

Redstart, American, 10, 11, 130, 149-150

Robin, American, 10, 11, 14, 15, 18, 108, 118-119

Sanderling, 76

Sandpiper, Baird's, 78

Buff-breasted, 79

Least, 77 
Pectoral, 78

Semipalmated, 76-77

Solitary, 72.73

Spotted, 15, 73

Stilt, 78-79

Upland, 23, 71-72

Western, 77

White-rumped, 77-78

Sapsucker, Yellow-bellied, 10, 92, 95-96

Scaup, Greater, 45-46

Lesser, 46-47

Scoter, Black, 49

Surf, 49

White-winged, 48-49

Shoveler, Northern, 42

Shrike, Loggerhead, 23, 127

Northern, 126-127

Siskin, Pine, 12, 13, 93, 159, 165-166

Snipe, Common, 16, 75

Solitaire, Townsend's, 123

Sora, 15, 16, 67

Sparrow, Baird's, 23, 169-170

Chipping, 12, 13, 14, 159, 174

Clay-colored, 14, 18, 159, 174-175

Field, 11, 14, 18, 23, 159, 175-176

Fox, 177

Grasshopper, 17, 18, 23, 159, 169

Harris', 176

Henslow's, 17, 18, 159, 170-171

House, 18, 22, 150

Lark, 172

Le Conte's, $16,17,170$

Lincoln's, 159, 178

Savannah, 17, 18, 159, 168-169

Sharp-tailed, 23, 171

Song, 12, 13, 15, 16, 17, 18, 159, 179

Swamp, 13, 15, 16, 17, 159, 178-179

Tree, 93, 173-174

Vesper, 11, 17, 18, 23, 159, 171-172

White-crowned, 176

White-throated, $10,12,13,159,176.177$

Starling, 18, 21, 128

Swallow, Bank, 92, 105

Barn, 92, 106

Cliff, 15, 92, 106

Rough-winged, 15, 92, 105-106

Tree, 15, 16, 92, 104-105

Swan, Whistling, 34

Swift, Chimney, 18, 90 
Tanager, Scarlet, 10, 11, 157

Summer, 158

Teal, Blue-winged, 15, 16, 17, 18, 40-41

Cinnamon, 41

Green-winged, 15, 39-40

Tern, Black, 15, 23, 82-83

Caspian, 23, 82

Common, 23, 81

Forster's, 23, 82

Least, 81

Thrasher, Brown, 11, 12, 14, 18, 108, 118

Thrush, Gray-cheeked, 121

Hermit, 12, 13, 14, 108, 120

Swainson's, 120-121

Varied, 119

Wood, 10, 108, 119-120

Titmouse, Tufted, 10, 93, 111-112

Towhee, Green-tailed, 168

Rufous-sided, 11, 14, 18, 159, 168

Turnstone, Ruddy, 73

Veery, 10, 13, 16, 108, 121-122

Vireo, Bell's, 128-129

Philadelphia, 131

Red-eyed, 10, 130-131

Solitary, 10, 13, 129-130

Warbling, 10, 130, 131-132

White-eyed, 128

Yellow-throated, 10, 11, 129, 130

Vulture, Turkey, 52

Warbler, Bay-breasted, 142-143

Black-and-white, 10, 12, 13, 130, 132-133

Blackburnian, 12, 130, 141

Blackpoll, 143

Black-throated Blue, 138-139

Black-throated Green, 130, 140

Blue-winged, 10, 130, 134-135

Brewster's, 134

Canada, 12, 130, 149

Cape May, 130, 138

Cerulean, 10, 140-141

Chestnut-sided, 10, 130, 141-142

Connecticut, 14, 130, 146-147

Golden-winged, 12, 17, 18, 130, 133-134

Hooded, 148

Kentucky, 146

Magnolia, 13, 130, 137-138

Mourning, 12, 130, 147

Nashville, 13, 14, 130, 136

Orange-crowned, 135-136 
Palm, 143-144

Pine, 12, 130, 143

Prothonotary, 133

Tennessee, 135

Wilson's, 149

Worm-eating, 133

Yellow, 10, 13, 15, 16, 17, 18, 130, 137

Yellow-rumped, 12, 13, 14, 130, 139-140

Waterthrush, Louisiana, 11, 145-146

Northern, 13, 17, 144-145

Waxwing, Bohemian, 125-126

Cedar, 126

Whimbrel, 71

Whip-poor-will, 11, 89

Wigeon, American, 41-42

Willet, 73

Woodcock, American, 74-75

Woodpecker, Black-backed Three-toed, 23, 93, 97

Downy, 10, 18, 92, 93, 96

Hairy, 10, 11, 12, 92, 93, 96

Northern Three-toed, 97

Pileated, 10, 12, 13, 92-94

Red-bellied, 10, 92, 93, 94

Red-headed, 11, 92, 93, 95

Wren, Bewick's, 23, 115

Carolina, 115-116

House, 11, 12, 14, 18, 108, 114-115

Long-billed Marsh, 15, 108, 116

Short-billed Marsh, 16, 17, 18, 108, 116-117

Winter, 13, 108, 115

Yellowlegs, Greater, 72

Lesser, 72

Yellowthroat, Common, 12, 13, 15, 16, 17, 18, 130, 147-148 